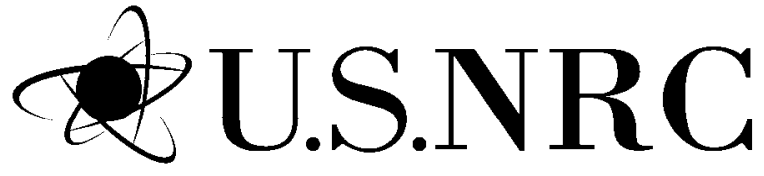

United States Nuclear Regulatory Commission

Protecting People and the Environment

\title{
Fabrication Flaw Density and Distribution In Repairs to Reactor Pressure Vessel and Piping Welds
}


United States Nuclear Regulatory Commission

Protecting People and the Environment

\section{Fabrication Flaw Density and Distribution In Repairs to Reactor Pressure Vessel and Piping Welds}

Manuscript Completed: July 2007

Date Published: April 2008

Prepared by

G.J. Schuster, F.A. Simonen, S.R. Doctor

Pacific Northwest National Laboratory

P.O. Box 999

Richland, WA 99352

W.E. Norris, NRC Project Manager

NRC Job Code N6398

Office of Nuclear Regulatory Research 


\begin{abstract}
The Pacific Northwest National Laboratory is developing a generalized fabrication flaw distribution for the population of nuclear reactor pressure vessels and for piping welds in U.S. operating reactors. The purpose of the generalized flaw distribution is to predict component-specific flaw densities. The estimates of fabrication flaws are intended for use in fracture mechanics structural integrity assessments. Structural integrity assessments, such as estimating the frequency of loss-of-coolant accidents, are performed by computer codes that require, as input, accurate estimates of flaw densities. Welds from four different reactor pressure vessels and a collection of archived pipes have been studied to develop empirical estimates of fabrication flaw densities.

This report describes the fabrication flaw distribution and characterization in the repair weld metal of vessels and piping. This work indicates that large flaws occur in these repairs. These results show that repair flaws are complex in composition and sometimes include cracks on the ends of the repair cavities. Parametric analysis using an exponential fit is performed on the data.

The relevance of construction records is established for describing fabrication processes and product forms. An analysis of these records shows there was a significant change in repair frequency over the years when these components were fabricated. A description of repair flaw morphology is provided with a discussion of fracture mechanics significance. Fabrication flaws in repairs are characterized using optimized-access, high-sensitivity nondestructive ultrasonic testing. Flaw characterizations are then validated by other nondestructive evaluation techniques and complemented by destructive testing.
\end{abstract}




\section{Foreword}

This report describes the fabrication flaw distribution and characterization in the repair weld metal of reactor pressure vessels (RPV) and piping. Construction records were analyzed to establish the fabrication processes used. Empirical studies were performed on RPV welds obtained from Shoreham, Hope Creek Unit 2, River Bend Unit 2, the Pressure Vessel Research User Facility (PVRUF), and Pilgrim Unit 2. The Shoreham vessel is a boiling water reactor (BWR) vessel that was assembled by Combustion Engineering (CE) in the years 1968-1974. CE also manufactured the PVRUF pressurized water reactor vessel (1976-1981). Chicago Bridge \& Iron manufactured the BWR vessels for Hope Creek Unit 2 (1971-1975) and River Bend Nuclear Plant Unit 2 (1974-1978). Sections of pipe obtained from Pilgrim Unit 2 and from the Beaver Valley Nuclear Power Plant were analyzed to assess any repairs performed and determine the fabrication flaw distribution.

The objective of the research was to determine the relevant properties of flaws created during the fabrication of nuclear component weldments and develop data on the density and distribution of fabrication flaws in the welds. Analyses have shown that vessel behavior is sensitive to flaw location, type, size, orientation, and other flaw characteristics. Weld material was cut and machined surfaces were prepared for ultrasonic inspection. The results of the inspections were used to characterize the fabrication flaw distributions in the weldments. Accurate estimates of flaw density and distribution are required as input to the computer codes performing structural integrity assessments.

Evaluations of repair welds have shown that the repair weld metal can have a significant number of flaws. This study indicates that repair weld metal in RPVs and piping is a significant source of flaws. Large flaws were found in the RPV repairs, and they were difficult to detect and distinguish from other weld discontinuities. It was also found that the larger flaws were a complex mixture of cracks, lack of fusion, slag, inclusions, and porosity and sometimes include cracks on the ends of the repair cavity. It was determined that flaws can repeat on successive weld passes, a phenomenon of interest to weld simulation models. Flaw distributions also differed by manufacturer. Current ASME International Code requirements do not have any special requirements to address fabrication repairs because the assumption is that the repairs are perfect (flaw-free weld metal). The weld repairs found in the piping evaluated did not contain large flaws located on the ends of the repair cavities as found for the RPV repairs. The primary focus of this study was RPVs however. A limited number of piping segments were available for evaluation. Thus, it would be difficult to make any generic conclusions with regard to piping. The NRC is further investigating the effects of repairs to piping welds.

It should be noted that fewer repairs were found in later vessel material. Better plate material and improved welding practices reduced flaw rates. Improved interpretation of nondestructive examination indications also was an important factor in reducing repair frequency. The Nuclear Regulatory Commission use the data from this report in its re-evaluation of the technical basis for Title 10 of the Code of Federal Regulations (CFR) 50.61, "Fracture toughness requirements for protection against pressurized thermal shock events." Based on the experimental data from this study in conjunction with calculations and expert judgment, it has been concluded that the risk of through-wall cracking due to pressurized thermal shock events is much lower than previously calculated. The NRC has initiated rulemaking activities to revise 10 CFR 50.61. 


\section{Contents}

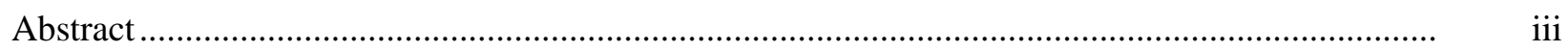

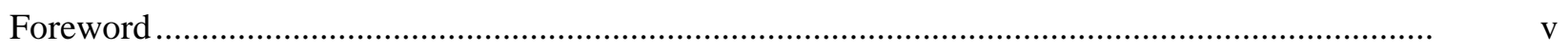

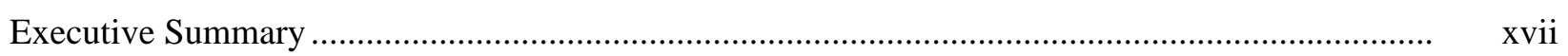

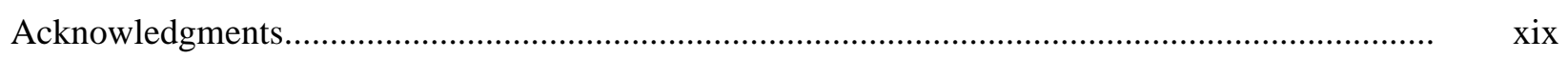

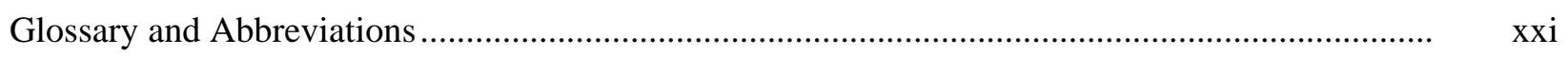

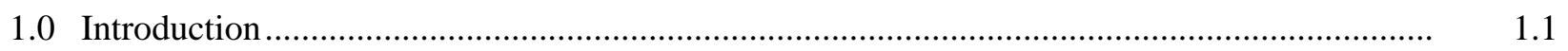

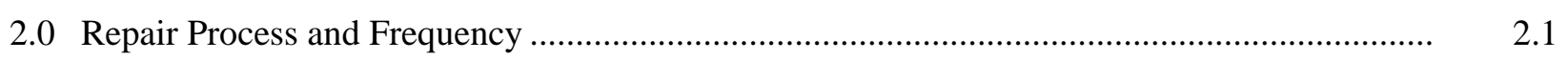

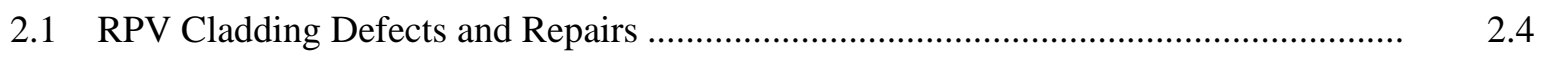

2.2 RPV Base Metal Defects and Repairs .................................................................. 2.10

2.3 RPV Material Handling Defects and Repairs........................................................... 2.16

2.4 RPV Seam Weld Defects and Repairs................................................................... 2.26

2.5 RPV Miscellaneous Defects and Repairs ............................................................... 2.44

2.5.1 Weld Preparation Surface Repairs ............................................................. 2.44

2.5.2 J-Weld Defects and Repairs .................................................................... $\quad 2.45$

2.5.3 Control Rod Drive Nozzle Defects and Repairs............................................ 2.47

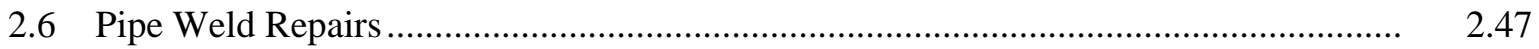

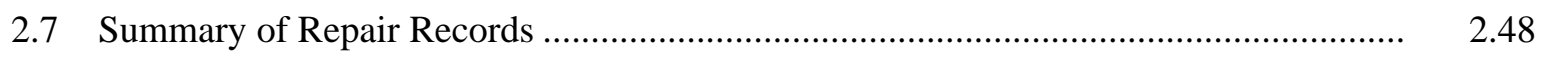

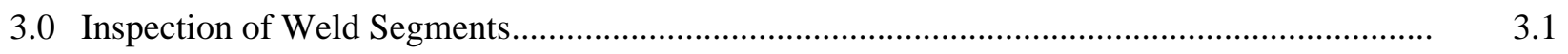

3.1 Shoreham Reactor Pressure Vessel Weldments ...........................................................

3.2 PVRUF Reactor Pressure Vessel............................................................................

3.3 Hope Creek Unit 2 Reactor Pressure Vessel Weldments ............................................ 3.7

3.4 River Bend Unit 2 Reactor Pressure Vessel Weldments ..............................................

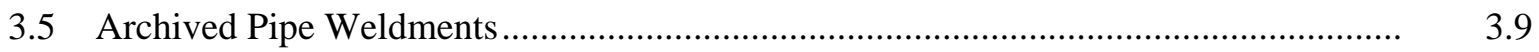

4.0 Repair Flaw Morphology and Fracture Mechanics Considerations ......................................... 4.1

4.1 Morphology of Repair Flaws .............................................................................. 4.2

4.2 Fracture Mechanics Considerations for Repair Flaws.............................................. 4.13

5.0 Confirmed Flaw Frequency and Distribution in Repairs ................................................... 5.1

5.1 Validated Flaw Density in Shoreham Reactor Pressure Vessel Repairs ...................... 5.1

5.2 Validated Flaw Density in PVRUF Reactor Pressure Vessel Repairs .......................... 5.2

5.3 Validated Flaw Density in Hope Creek Unit 2 Reactor Pressure Vessel ...................... 5.3

5.4 Repairs to Dissimilar Metal Welds of Piping ............................................................ 5.10

5.5 Repair Flaw Location Distribution.................................................................... 5.11 


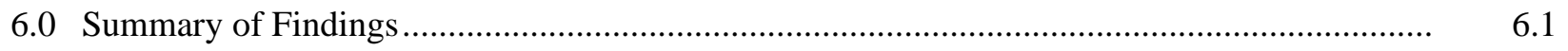

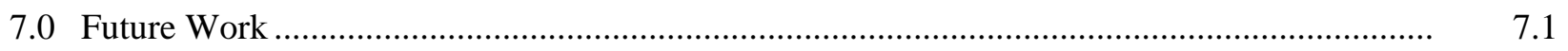

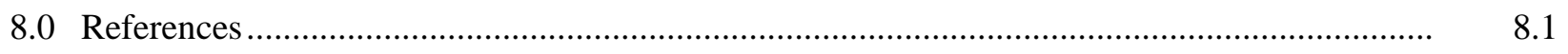

Appendix A - Metallography ........................................................................................ A.1

Appendix B - Scanned Electron Microscopy …................................................................... B.1 


\section{Figures}

E.1 Comparison of Flaw Density and Through-Wall Size Distributions for Repair Flaws in

Three Reactor Pressure Vessels and in a Dissimilar Metal Piping Weld.....

xviii

2.1 Repair Record Types, Fields, and Relationships from Construction Records of

PVRUF Reactor Pressure Vessel....

2.2 Roll-Out Diagram for Seam Welds in PVRUF Reactor Pressure Vessel Showing

Weld Identification Numbers

2.3 Hope Creek Unit 2 and River Bend Unit 2 Reactor Pressure Vessel Repair Records and Their Relationships .

2.4 Comparison of Cavity Length of Cladding Repairs in the Hope Creek Unit 2 and River Bend Unit 2 RPVs

2.5 Comparison of Estimated Repair Frequency in the Cladding of Three RPVs

2.6 Comparison of Cavity Length in the Base Metal of Hope Creek Unit 2 and River Bend Unit 2 RPVs

2.7 Comparison of Estimated Repair Frequency in the Base Metal of Three RPVs .

2.8 Comparison of Cavity Length for Repair of Material Handling Defects in the Hope Creek Unit 2 and River Bend Unit 2 RPVs

2.9 Comparison of Estimated Repair Frequency for Material Handling Defects in Three Reactor Pressure Vessels .

2.10 Comparison of Defect Length in the Seam Welds of the Hope Creek Unit 2 and River Bend Unit 2 RPVs

2.11 Comparison of Flaw Length in the Seam Welds of Three RPVs

2.12 Comparison of Estimated Repair Frequency for the Seam Welds in Three RPVs...

2.13 Summary of Repair Frequency for Three Reactor Pressure Vessels.

3.1 Hope Creek Unit 2 Base Metal Specimen in the NDE Laboratory for Ultrasonic Inspection Using Cut and Machined Surface

3.2 Location of an Undocumented Repair in Shoreham Specimen C120E.

3.3 Sectioning of Repair Metal from Hope Creek Unit 2.

3.4 Image of Repair Flaw Using Film Radiography

3.5 Schematic Representation of Seam Welds in Four Shell Courses of the Shoreham Vessel with the Identification Numbers of the Welds in Material Studied

3.6 Shoreham Specimens in the PNNL NDE Laboratory, Prepared for Weld-Normal Inspection

3.7 PVRUF Reactor Pressure Vessel at Oak Ridge National Laboratory

3.8 PNNL Reactor Pressure Vessel Specimen as Received from Hope Creek Unit 2

3.9 River Bend Unit 2 RPV During Disassembly

3.10 Dissimilar Metal Weld Specimen at PNNL - Safe End to 91-cm-Diameter Carbon Steel Elbow Weld.... 
4.1 Radiographic Images of PVRUF 17-mm Flaw in OD Seam Weld Repair

4.2 Micrograph of Portion of PVRUF 17-mm Flaw Showing Location and Composition...

4.3 Micrograph Showing Magnified View of Portion of PVRUF 17-mm Flaw ...

4.4 Micrograph Showing Magnified View of Crack-Like Portion of PVRUF $17 \mathrm{~mm}$ Flaw .

4.5 Weld-Normal UT C-Scan Image of Weld Fusion Zone Showing Profile of Weld Repair Cavity and Location of PVRUF 17-mm Flaw

4.6 Focused Ultrasound Result Showing Top View of PVRUF 12-mm Repair Flaw ....

4.7 Focused Ultrasound Result Showing Side View of PVRUF 12-mm Flaw

4.8 Focused Ultrasound Result Showing End View of PVRUF 12-mm Flaw

4.9 High-Resolution Image of Shoreham 14-mm Repair Flaw .

4.10 Weld-Normal UT C-Scan Image of Flaw in Fusion Zone and on End of Repair Cavity C in Hope Creek Unit 2 Reactor Pressure Vessel...

4.11 Micrograph, as Machined, of Portion of Crack in Hope Creek Unit 2 RPV

Specimen C2CC

4.12 Micrograph, as Machined, of Portion of Crack in Hope Creek Unit 2 RPV

Specimen C2CC

4.13 Micrograph, as Polished and Etched, of Portion of Crack in Hope Creek Unit 2 RPV Specimen C2CC.

4.14 Electron Image of Portion of Two Cracks in Hope Creek Unit 2 RPV Specimen C2CC

4.15 Elemental Composition of Weld Metal in Hope Creek Unit 2 RPV Specimen C2CC ..........

4.16 X-Ray Spectrum from Elemental Analysis of Weld Metal in Hope Creek Unit 2 RPV Specimen C2CC..

4.17 Electron Image of Portion of Crack in Hope Creek Unit 2 RPV Specimen C2CC ................

4.18 Elemental Composition of Contamination in Crack in Hope Creek Unit 2 RPV Specimen C2CC

4.19 X-Ray Spectrum from Elemental Analysis of Contamination in Crack in Hope Creek Unit 2 RPV Specimen C2CC

4.20 Shoreham 14-mm Repair Flaw with More Conservative Treatment A of Flaw Dimensions

4.21 Shoreham 14-mm Repair Flaw with Less Conservative Treatment B of Flaw Dimensions

4.22 Shoreham 32-mm Repair Flaw with More Conservative Treatment A of Flaw Dimensions

4.23 Shoreham 32-mm Repair Flaw with Less Conservative Treatment B of Flaw Dimensions

5.1 Through-Wall Dimension and Reduced Size Distribution Based on Fracture Mechanics for Flaws in Repairs in Seam Welds of Shoreham Reactor Pressure Vessel ....... 
5.2 Through-Wall Dimension and Reduced Size Distribution Based on Fracture Mechanics Considerations for Flaws in Repairs in Seam Welds of PVRUF Reactor Pressure Vessel

5.3 Validated and Unvalidated Through-Wall Size Distribution for Flaws in Seam Weld Repair A for Seam BE in Hope Creek Unit 2 Reactor Pressure Vessel

5.4 Validated and Unvalidated Through-Wall Size Distribution for Flaws in Seam Weld Repair C for Seam BE in Hope Creek Unit 2 Reactor Pressure Vessel

5.5 Validated and Unvalidated Through-Wall Size Distribution for Flaws in Weld Preparation Surface Repair C on Base Metal Piece 22-2 for Seam BE in Hope Creek Unit 2 Reactor Pressure Vessel

5.6 Validated and Unvalidated Through-Wall Size Distribution for Flaws in Weld Preparation Surface Repair D on Base Metal Piece 22-2 for Seam BE in Hope Creek Unit 2 Reactor Pressure Vessel

5.7 Validated and Unvalidated Through-Wall Size Distribution for Flaws in Weld Preparation Surface Repair E on Base Metal Piece 22-2 for Seam BE in Hope Creek Unit 2 Reactor Pressure Vessel

5.8 Validated Cumulative Through-Wall Size Distribution for Seam Weld Repairs and Weld Preparation Surface Repairs in the Hope Creek Unit 2 Reactor Pressure Vessel .........

5.9 Validated and Unvalidated Cumulative Through-Wall Size Distribution for Flaws in Repairs in Dissimilar Metal Welds of Piping

5.10 Distribution of Repair Flaws Through the Cavity Depth in Centimeters from the Cavity Surface

5.11 Distribution of Repair Flaws Through the Cavity as a Fraction of the Cavity Depth .............

6.1 Comparison of Flaw Density and Through-Wall Size Distributions for Repair Flaws in Three Reactor Pressure Vessels and in Dissimilar Metal Welds of Piping. 


\section{Tables}

2.1 Construction Record Contents for Repairs in Cladding of Three Reactor Pressure Vessels

2.2 Unsatisfactory Inspections in Cladding of the Bottom Head of the PVRUF RPV ................ 2.6

2.3 Unsatisfactory Inspections in Cladding in the Shell of the PVRUF RPV ............................ 2.6

2.4 Cladding Defects in the Bottom Head of the Hope Creek Unit 2 RPV ................................ 2.6

2.5 Estimated Surface Area and Volume of Cladding Repairs in the Bottom Head of the

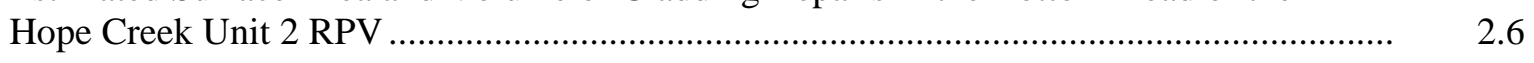

2.6 Cladding Defects in the Shell of the Hope Creek Unit 2 RPV .......................................... 2.7

2.7 Estimated Surface Area and Volume of Cladding Repairs in the Shell of the Hope

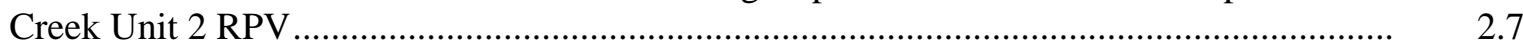

2.8 Cladding Defects in the Nozzles of the Hope Creek Unit 2 RPV ........................................ 2.8

2.9 Estimated Surface Area and Volume of Cladding Repairs in the Nozzles of the

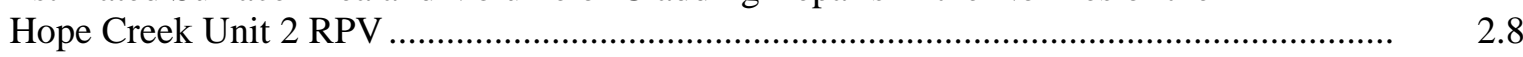

2.10 Cladding Defects in the Shell of the River Bend Unit 2 RPV ............................................. 2.8

2.11 Estimated Surface Area and Volume of Cladding Repairs in the Shell of the River Bend Unit 2 RPV

2.12 Construction Record Contents for Repairs in Base Metal of Three Reactor Pressure Vessels

2.13 Unsatisfactory Inspections in Base Metal of Top Head of the PVRUF RPV ...................... 2.11

2.14 Unsatisfactory Inspections in Base Metal of Shell of the PVRUF RPV ............................. 2.11

2.15 Unsatisfactory Inspections in Base Metal of Nozzles of the PVRUF RPV ......................... 2.11

2.16 Estimated Surface Area and Volume of Base Metal Repairs in the Nozzles of the PVRUF RPV

2.17 Base Metal Defects in the Bottom Head of the Hope Creek Unit 2 RPV ........................... 2.12

2.18 Estimated Surface Area and Volume of Base Metal Repair in the Bottom Head of the Hope Creek Unit 2 RPV ............................................................................................ 2.13

2.19 Base Metal Defects in the Shell of the Hope Creek Unit 2 RPV ........................................ 2.13

2.20 Estimated Surface Area and Volume of Base Metal Repair in the Shell of the Hope Creek Unit 2 RPV

2.21 Base Metal Defects in the Nozzles of the Hope Creek Unit 2 RPV ................................... 2.14

2.22 Estimated Surface Area and Volume of Base Metal Repair in the Nozzles of the Hope Creek Unit 2 RPV

2.23 Base Metal Defects in the Top Head of the River Bend Unit 2 RPV .................................. 2..

2.24 Estimated Surface Area and Volume of Base Metal Repair in the Top Head of the River Bend Unit 2 RPV.. 
2.25 Construction Record Contents for Material Handling Repairs in Three Reactor

Pressure Vessels

2.26 Unsatisfactory Inspections from Material Handling of the Top Head of the PVRUF RPV

2.27 Unsatisfactory Inspections from Material Handling of the Bottom Head of the PVRUF RPV

2.28 Unsatisfactory Inspections from Material Handling of the Shell of the PVRUF RPV

2.29 Material Handling Defects in the Bottom Head of the Hope Creek Unit 2 RPV

2.30 Estimated Surface Area and Volume of Material Handling Repair in the Bottom Head of the Hope Creek Unit 2 RPV

2.31 Material Handling Defects in the Top Head of the Hope Creek Unit 2 RPV.

2.32 Estimated Surface Area and Volume of Material Handling Repair in the Top Head of the Hope Creek Unit 2 RPV.

2.33 Material Handling Defects in the Shell of the Hope Creek Unit 2 RPV

2.34 Estimated Surface Area and Volume of Material Handling Repair in the Shell of the Hope Creek Unit 2 RPV

2.35 Material Handling Defects in the Nozzles of the Hope Creek Unit 2 RPV...

2.36 Estimated Surface Area and Volume of Material Handling Repair in the Nozzles of the Hope Creek Unit 2 RPV

2.37 Material Handling Defects in the Bottom Head of the River Bend Unit 2 RPV .

2.38 Estimated Surface Area and Volume of Material Handling Repair in the Bottom Head of the River Bend Unit 2 RPV

2.39 Material Handling Defects in the Top Head of the River Bend Unit 2 RPV

2.40 Estimated Surface Area and Volume of Material Handling Repair in the Top Head of the River Bend Unit 2 RPV.

2.41 Material Handling Defects in the Shell of the River Bend Unit 2 RPV

2.42 Estimated Surface Area and Volume of Material Handling Repair in the Shell of the River Bend Unit 2 RPV.

2.43 Material Handling Defects in the Nozzles of the River Bend Unit 2 RPV

2.44 Estimated Surface Area and Volume of Material Handling Repair in the Nozzles of the River Bend Unit 2 RPV

2.45 Construction Record Contents for Seam Repairs and Acceptable Indications in Three Vessels.

2.46 Unsatisfactory Inspections in Seam Weld of the Top Head of the PVRUF RPV ...

2.47 Acceptable Flaws in Seam Weld of the Top Head of the PVRUF RPV

2.48 Estimated Surface Area and Volume of Seam Weld Repairs to the Top Head of the PVRUF RPV 
2.50 Acceptable Flaws in Seam Weld of the Bottom Head of the PVRUF RPV

2.51 Estimated Surface Area and Volume of Seam Weld Repairs in the Bottom Head of the PVRUF RPV.

2.52 Unsatisfactory Inspections in Seam Weld in the Shell of the PVRUF RPV ...

2.30

2.53 Acceptable Flaws in Seam Weld of the Long Seams of the Shell of the PVRUF RPV.

2.31

2.54 Estimated Surface Area and Volume of Seam Weld Repairs in the Long Seams of the Shell of the PVRUF RPV .

2.55 Acceptable Flaws in the Seam Weld in the Girth Seams of the Shell of the PVRUF RPV

2.56 Estimated Surface Area and Volume of Seam Weld Repairs in the Girth Seams of the Shell of the PVRUF RPV .

2.57 Unsatisfactory Inspections in Nozzle to Vessel Welds of the PVRUF RPV

2.58 Acceptable Flaws in Inlet Nozzle to Vessel Welds of the PVRUF RPV .

2.59 Acceptable Flaws in the Outlet Nozzle to Vessel Welds of the PVRUF RPV.

2.60 Estimated Surface Area and Volume of Weld Repairs in the Nozzle to Vessel Welds of the PVRUF RPV

2.61 Seam Weld Defects in the Bottom Head of the Hope Creek Unit 2 RPV

2.62 Estimated Surface Area and Volume of Seam Weld Repairs in the Bottom Head of the Hope Creek Unit 2 RPV

2.63 Seam Weld Defects in the Top Head of the Hope Creek Unit 2 RPV

2.64 Estimated Surface Area and Volume of Seam Weld Repair in the Top Head of the Hope Creek Unit 2 RPV

2.65 Seam Weld Defects in the Shell of the Hope Creek Unit 2 RPV .

2.66 Estimated Surface Area and Volume of Seam Weld Repair in the Shell of the Hope Creek Unit 2 RPV

2.67 Seam Weld Defects in the Nozzles of the Hope Creek Unit 2 RPV .

2.68 Estimated Surface Area and Volume of Seam Weld Repair in the Nozzles of the Hope Creek Unit 2 RPV

2.69 Seam Weld Defects in the Top Head of the River Bend Unit 2 RPV .

2.70 Estimated Surface Area and Volume of Seam Weld Repair in the Top Head of the River Bend Unit 2 RPV.

2.71 Seam Weld Defects in the Shell of the River Bend Unit 2 RPV

2.72 Estimated Surface Area and Volume of Seam Weld Repair in the Shell of the River Bend Unit 2 RPV .

2.73 Seam Weld Defects in the Nozzles of the River Bend Unit 2 RPV

2.74 Estimated Surface Area and Volume of Seam Weld Repair in the Nozzles of the River Bend Unit 2 RPV. 
2.76 Indications Found and Repaired on the Weld Preparation Surfaces of the Hope Creek Unit 2 RPV

2.77 Surface Area and Volume of Repair Cavities on Weld Preparation Surfaces of the Hope Creek Unit 2 RPV

2.78 Unsatisfactory Inspections in the Control Rod Drive Mechanism J Welds of the PVRUF RPV

2.79 Welding and Handling Defects in the Control Rod Drive J-Welds of the Hope Creek Unit 2 RPV

2.80 Estimated Surface Area and Volume of Repair Cavities in the Control Rod Drive J-Welds of the Hope Creek Unit 2 RPV...

2.81 Welding Defects in the Control Rod Drive J-Welds of the River Bend Unit 2 RPV .............

2.82 Surface Area and Volume of Repair Cavities in the Control Rod Drive J-Welds of the River Bend Unit 2 RPV

2.83 Handling Defects in the Control Rod Drive Nozzles of the Hope Creek Unit 2 RPV ...........

2.84 Surface Area and Volume of Repair Cavities in the Control Rod Drive Nozzles of Hope Creek 2 RPV

2.85 Dimensions of Repairs in Dissimilar Metal Weld Specimens.............................................

2.86 Volume and Area of Repairs in Dissimilar Metal Weld Specimens .....

2.87 Frequency of Repair from the Inside Surface of Three Reactor Pressure Vessels.

2.88 Frequency of Repair from the Outside Surface of Three Reactor Pressure Vessels

2.89 Frequency of Repair where the Repair Surface was Not Specified in Three Reactor Pressure Vessels

3.1 Reactor Material Selected for Study .............................................................................

3.2 Method Used to Fabricate Welds

3.3 Material from Three Base Metal Plates in the Hope Creek Unit 2 RPV Specimen at PNNL

3.4 Seam Weld Metal from Two Welds in the Hope Creek Unit 2 PRV Specimen at PNNL

5.1 Through-Wall Dimension Distribution for Flaws in Shoreham Repairs.

5.2 Reduced Through-Wall Size Distribution for Flaws in Repairs.

5.3 Through-Wall Dimension Distribution for Flaws in PVRUF Repairs

5.4 Reduced Through-Wall Size Distribution for Flaws in PVRUF Repairs.

5.5 Unvalidated Through-Wall Dimension Distribution for Flaws in Hope Creek 2

Seam Repair A.

5.6 Validated Through-Wall Dimension Distribution for Flaws in Hope Creek 2 Seam Repair A.

5.7 Unvalidated Through-Wall Dimension Distribution for Flaws in Hope Creek 2 
5.8 Validated Through-Wall Dimension Distribution for Flaws in Hope Creek 2

Seam Repair C.

5.9 Unvalidated Through-Wall Dimension Distribution for Flaws in Hope Creek 2 Weld

Preparation Surface Repair C .

5.10 Validated Through-Wall Dimension Distribution for Flaws in Hope Creek 2 Weld Preparation Surface Repair C .

5.11 Unvalidated Through-Wall Dimension Distribution for Flaws in Hope Creek 2 Weld

Preparation Surface Repair D

5.12 Validated Through-Wall Dimension Distribution for Flaws in Hope Creek 2 Weld Preparation Surface Repair D.

5.13 Unvalidated Through-Wall Dimension Distribution for Flaws in Hope Creek 2 Weld Preparation Surface Repair E

5.14 Validated Through-Wall Dimension Distribution for Flaws in Hope Creek 2 Weld Preparation Surface Repair E

5.15 Unvalidated Through-Wall Dimension Distribution for Flaws in Hope Creek 2 for Three Weld Preparation Surface Repairs

5.16 Validated Through-Wall Dimension Distribution for Flaws in Hope Creek 2 for Two Seam Repairs.

5.17 Unvalidated Through-Wall Size Distribution for Flaws in Repairs

5.18 Validated Through-Wall Size Distribution for Flaws in Repairs

6.1 Exponential Fit Results for Through-Wall Size 


\section{Executive Summary}

This report presents results of empirical studies on nuclear materials from cancelled U.S. nuclear power plants. The studies were conducted to develop data on the density and distribution of fabrication flaws in selected nuclear reactor components. These inspection-based results are intended to help characterize the initial fabrication flaw distributions in weldments for use in probabilistic fracture mechanics codes. Reactor pressure vessel weld segments were obtained from Shoreham, Hope Creek Unit 2, River Bend Unit 2, and the Pressure Vessel Research User Facility (PVRUF). Dissimilar metal weld piping sections were obtained from a cancelled Combustion Engineering plant (Pilgrim Unit 2).

Pacific Northwest National Laboratory (PNNL) found weld repairs in all this material except for that from the River Bend Unit 2 reactor pressure vessel, where only unrepaired weld segments were obtained. PNNL's data acquired on repairs in the weld segments were analyzed to determine the fabrication flaw density and size distribution. Descriptions of the source welds are provided in the report. The inspections detected many fabrication flaws in the repairs, and the data were analyzed for density and distribution. An estimate of flaw density and distribution was made, and the results for through-wall size distribution are given in Figure E.1.

This research on material removed from selected nuclear reactor components was performed to validate the presence of repair flaws and the characteristics of the repair flaw density and distribution and to provide confirmed flaw statistics for use in probabilistic fracture mechanics analysis. The report describes the methodology used by PNNL to produce repair flaw densities. A description of repair flaw morphology is provided, with a discussion of fracture mechanics significance. The data acquired on the flaws are presented along with estimates of flaw densities. The report also describes the size and number of repairs as found in the construction records.

The construction records for the reactor pressure vessels are analyzed in this report. Construction record data show the flaw length distribution for flaws found during the repair process as a way to illustrate the change in weld quality between the vessels. Changes in the weld procedure specification, the quality of the weld materials, and other factors may explain the change by a factor of 10 in defect densities in the seam welds for the vessels.

The weld repairs found in the dissimilar metal weld did not contain large flaws located on the ends of the repair cavities as PNNL found for the reactor pressure vessel repairs. One explanation for the difference is that the welding procedures used to make the repairs may have been significantly different-possibly the piping procedure required a repair cavity that allowed the weld pass to start and stop at the surface of pipe. Perhaps the repair metal we studied is not representative of all the repairs in piping.

Among the principal findings of this overall study is that the repair weld metal is a significant source of flaws. Second, the larger flaws are a complex mixture of cracks, lack of fusion, slag, inclusions, and porosity. Flaws can repeat on successive weld passes, a phenomenon of interest to weld simulation models. 


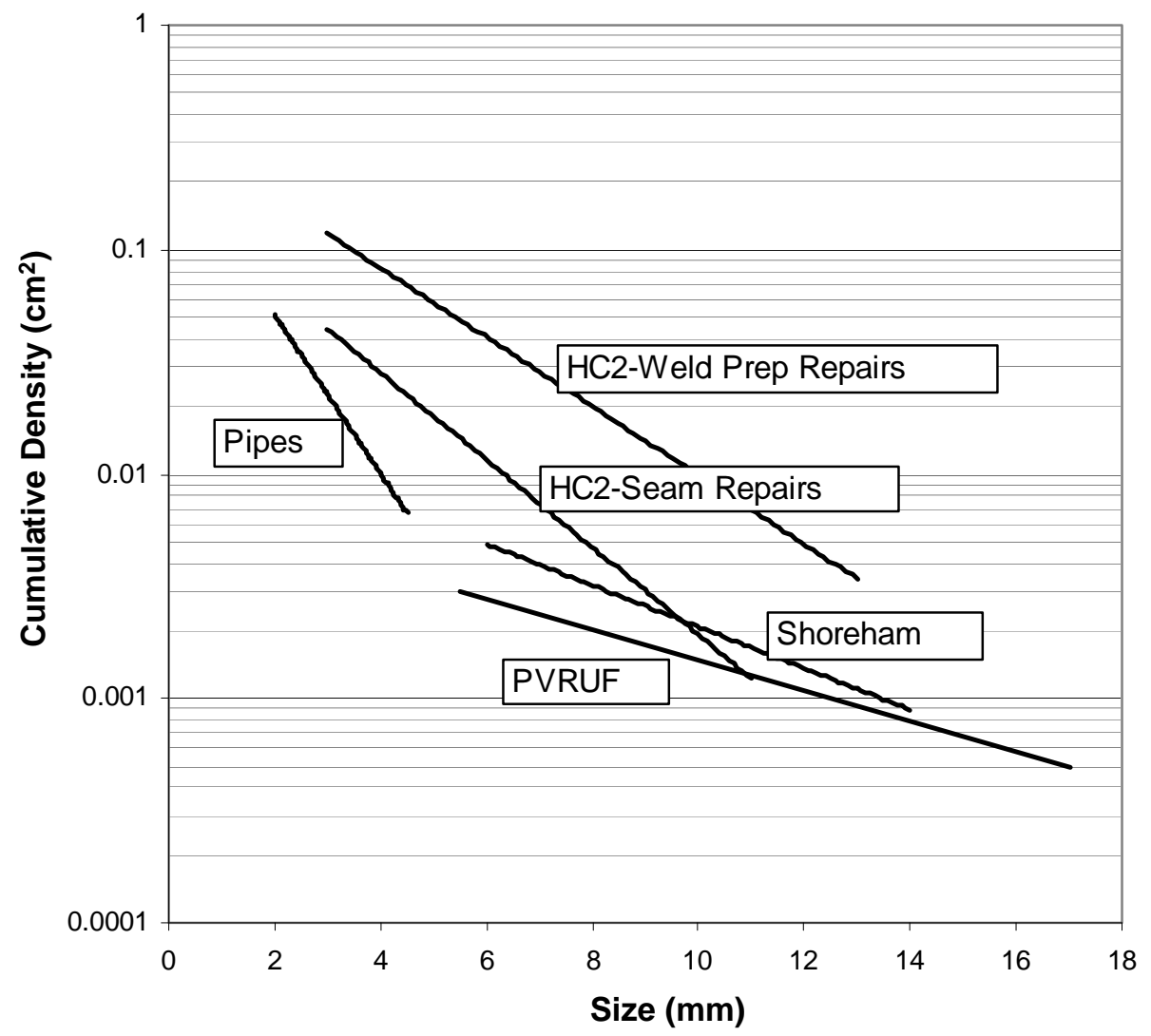

Figure E.1 Comparison of Flaw Density and Through-Wall Size Distributions for Repair Flaws in Three Reactor Pressure Vessels and in a Dissimilar Metal Piping Weld. HC2 stands for the Hope Creek Unit 2 vessel. No weld repairs were found in the weld segments from the River Bend Unit 2 vessel. 


\section{Acknowledgments}

This work was supported by the U.S. Nuclear Regulatory Commission under NRC JCN W6604, Mr. Wallace E. Norris, NRC project manager; and NRC JCN Y6534, Ms. Carol E. Moyer, NRC project manager. The work was conducted at Pacific Northwest National Laboratory; Battelle operates this multiprogram national laboratory for the U.S. Department of Energy under Contract DE-AC05-76RL01830.

The authors thank Earlene Prickett for assistance in preparing the manuscript and Andrea J. Currie for technical editing support. The authors acknowledge Natalio T. Saenz for the metallographic results and James E. Coleman for providing the electron microscopy. 


\section{Glossary and Abbreviations}

base metal

BGE

BWR

CB\&I
CE
CRD
CRDM
cumulative flaw density
defect

discontinuity

EPRI

flaw

flaw density

flaw depth size

flaw distribution

fusion line

GTAW

HC2

HAZ

indication (of a flaw)

inclusion the metal that composes the plates or forged rings of a reactor pressure vessel - the plates forming the vessel by butt-welding

Baltimore Gas \& Electric Company

boiling water reactor - a nuclear reactor in which the coolant is water

Chicago Bridge \& Iron

Combustion Engineering

control rod drive

control rod drive mechanism

the density of flaws greater than a specified size

a discontinuity or discontinuities that by nature or accumulated effect (for example, total crack length) render a part of product unable to meet minimum applicable acceptance standards or specifications.

an interruption of the typical structure of a weldment, such as a lack of homogeneity in the mechanical, metallurgical, or physical characteristics of the material or weldment - A discontinuity is not necessarily a defect. See also defect and flaw (AWS 1984).

Electric Power Research Institute

an imperfection or unintended discontinuity in a material - a void, porosity, inclusion, lack of fusion, or crack that is physically distinct from the metallic microstructure

the number of flaws per unit length, area, or volume

see through-wall extent

the number of flaws measured in separate categories

one of two lines on the cross section of the weld that form the boundary between the weld metal and the base metal

gas-tungsten-arc weld

Hope Creek Unit 2

heat-affected zone - a portion of the base metal (adjacent to the weld) whose microstructure is altered by heat deposited during welding

the response or evidence of a flaw from the application of nondestructive evaluation - for ultrasonic testing, a coherent packet of (ultrasonic) energy that is characterized as originating from a flaw

a foreign solid, (e.g., slag, scale, oxide, or nonmetallic substance) entrapped in the base metal or weld metal 


\begin{tabular}{|c|c|}
\hline LOF & $\begin{array}{l}\text { lack of fusion - lack of metallic bond between weld passes or between a } \\
\text { weld pass and the base metal }\end{array}$ \\
\hline LTOP & low-temperature overpressurization \\
\hline LWR & $\begin{array}{l}\text { light water reactor - either of two nuclear fission reactor designs (see } B W R \\
\text { and } P W R \text { ) that heat water as a means of power production }\end{array}$ \\
\hline laminar flaws & $\begin{array}{l}\text { planar flaws that are oriented within } 10 \text { degrees of a plane parallel to the } \\
\text { surface of the component - see ASME (1998) }\end{array}$ \\
\hline Marshall Distribution & $\begin{array}{l}\text { a flaw density in the weld metal of reactor pressure vessels - see Marshall } \\
\text { (1982) }\end{array}$ \\
\hline MT & magnetic particle testing \\
\hline NDE & nondestructive evaluation \\
\hline near-surface zone & $\begin{array}{l}\text { the first } 25 \mathrm{~mm} \text { ( } 1.0 \mathrm{in} .) \text { of reactor pressure vessel material from the } \\
\text { cladding's wetted surface }\end{array}$ \\
\hline $\begin{array}{l}\text { OD } \\
\text { outside the near-surface zone }\end{array}$ & $\begin{array}{l}\text { outside diameter } \\
\text { the remainder of vessel wall when the near-surface zone is excluded }\end{array}$ \\
\hline PFM & probabilistic fracture mechanics \\
\hline planar flaw & $\begin{array}{l}\text { a flat two-dimensional flaw in a plane other than parallel to the surface of } \\
\text { the component - In this study, it includes a crack or lack of fusion that is } \\
\text { primarily vertical in orientation in the vessel. }\end{array}$ \\
\hline porosity & a group of voids located close to each other \\
\hline PT & dye penetrant testing \\
\hline PTS & pressurized thermal shock \\
\hline PVRUF vessel & $\begin{array}{l}\text { The Pressure Vessel Research Users' Facility vessel, at Oak Ridge National } \\
\text { Laboratory, was a pressurized water reactor vessel from a canceled } \\
\text { U.S. plant - see Pennel (1989). }\end{array}$ \\
\hline PWR & $\begin{array}{l}\text { pressurized water reactor - a nuclear reactor in which the coolant is water, } \\
\text { maintained at such a pressure as to keep it from boiling }\end{array}$ \\
\hline RB2 & River Bend Unit 2 \\
\hline RPV & reactor pressure vessel \\
\hline RMS & root-mean-square \\
\hline $\mathrm{RT}$ & radiographic testing \\
\hline SAFT-UT & $\begin{array}{l}\text { synthetic aperture focusing technique for ultrasonic testing - see Doctor } \\
\text { (1996) }\end{array}$ \\
\hline size & see through-wall extent \\
\hline SMAW & shielded-metal-arc weld \\
\hline through-wall extent & $\begin{array}{l}\text { the maximum dimension, normal to the surface of the component, of the } \\
\text { rectangle circumscribing the flaw }\end{array}$ \\
\hline
\end{tabular}


void

volumetric flaw

weldment

weld metal

weld profile a volume of gas entrapped in the vessel material

a three-dimensional flaw such as a void, porosity, or inclusion - Also includes laminar flaws.

an assembly whose component parts are joined by welding (AWS 1984) that portion of a weld that has been melted during welding (AWS 1984) the shape of the weld metal when sectioned across the weld 


\subsection{Introduction}

The U.S. Nuclear Regulatory Commission (NRC) initiated a program at the Pacific Northwest National Laboratory (PNNL) with the major objective of estimating the density of fabrication flaws in U.S. light water reactor pressure vessels (RPVs) and piping welds (Jackson et al. 1999). PNNL's methodology for estimating the density and size distribution of fabrication flaws involves the nondestructive evaluation (NDE) of weldments from cancelled nuclear plants and the destructive validation of detected flaws. This methodology characterizes the flaws for fracture mechanics significance because the likelihood of vessel failure is sensitive to flaw location, type, size, orientation, and other flaw characterizations (Simonen and Khaleel 1995). The objective of this research is to estimate these and other relevant properties of flaws created during the fabrication of nuclear component weldments.

To meet this objective, a generalized flaw distribution is proposed because the density of fabrication flaws is expected to vary over product forms and over the years of component fabrication. In order to develop a generalized flaw distribution and to resolve technical issues, an expert judgment process was used. The results of this expert judgment process helped to formulate a generalized approach to fabrication flaw density and distribution (Jackson and Abramson 2000). The impaneled experts judged that the product forms and construction processes determine the fabrication flaws in weldments. So, for the $i$ th component, the number of flaws greater than size $x$ can be given by a sum over product forms

$$
N_{i}(x)=\sum_{j} \rho_{j}\left(t_{i}\right) \cdot V_{i j} \cdot G_{j}(x)
$$

where $\rho_{j}\left(t_{i}\right)$ is the flaw density in product form $\mathrm{j}$ during time interval for the construction of the $i$ th component $\mathrm{t}_{\mathrm{i}}, V_{i j}$ is the volume (or area) of the product form in a weldment or a region of a weldment, and $G_{j}(x)$ is the probability that a flaw, in product form $j$, has a size greater than $x$. PNNL data have shown that

$$
G_{j}(x)=\exp \left(-\beta_{j} x\right)
$$

provides a reasonable fit to the fabrication flaw data (Doctor and Schuster 2001).

Estimates for flaw densities are an important input to structural assessments by fracture mechanics calculations. Component failure is an issue of increasing concern as the current operating nuclear power plants reach the middle to latter portion of their license periods and have accumulated service-related degradation. Computer codes require accurate estimates of the flaw densities in the reactor component to determine the likelihood of a component failure. The majority of past work in probabilistic fracture mechanics (PFM) considered cracks to be expressed in terms of a single crack size parameter (size in the depth dimension). A two-dimensional crack is much more realistic but considerably more complex. Some PFM codes are capable of treating two-dimensional cracks and are based on the assumption that a two-dimensional crack is a semi-elliptical surface crack.

Fracture mechanics codes can provide the capability of considering more realistic and detailed flaw density information. Because of the lack of empirical data on fabrication flaw distributions in nuclear components, conservative assumptions are made about the initial flaw size distribution, aspect ratios, and through-wall locations. Studies (Simonen et al. 1986b; Simonen and Khaleel 1995) have shown that the 
probability of vessel rupture is sensitive to the location of the flaw in the vessel (i.e., near the inner surface versus interior of the vessel wall); the flaw type (e.g., cracks, lack of fusion, porosity, inclusions); and the flaw aspect ratio (i.e., flaw length as well as depth). Therefore, it is very useful to have flaw density estimates that are based on empirical data.

In this report, Section 2 reviews repair information from the construction records of RPVs from the Pressure Vessel Research Users' Facility (PVRUF), Hope Creek Unit 2, and River Bend Unit 2. Because Section 2 is complex and detailed, the reader may wish to skip it when reading the report for the first time and return to Section 2 after reading Sections 3 through 5. Section 3 reviews the origin and inspection of the weld segments and shows how the repairs were detected. Section 4 shows the morphology of repair flaws and discusses fracture mechanics considerations. Section 5 provides the validation results for the fabrication flaws found in repair metal in this study. Findings from the overall study are summarized in Section 6; Section 7 provides suggestions for future work. 


\subsection{Repair Process and Frequency}

Before components such as the reactor pressure vessel were declared ready for service, the manufacturing process included the detection, characterization, and repair of significant flaws. Nondestructive evaluation techniques were applied at various stages during fabrication to ensure that significant flaws were removed. This removal of fabrication flaws was accomplished by grinding out the flaws and filling the void with weld metal. This section of the report describes PNNL's efforts to establish the number and size of repairs during the fabrication of the materials analyzed.

The vessels were manufactured using specifications in the American Society of Mechanical Engineers (ASME) Boiler and Pressure Vessel Code Rules for Construction of Nuclear Pressure Vessels. All applicable Code Cases and addenda for Class A vessels that were in effect at the time of the purchase order also were applied. Later editions of the code may have been applied if agreed upon by the supplier.

For vessels like those from the PVRUF and River Bend Unit 2, constructed in the late 1970s, few repairs were made in contrast to what has been reported in earlier vessels. The Hope Creek Unit 2 RPV and the Shoreham RPV, constructed in the early 1970s, can be considered earlier vessels. Better plate material and improved welding practices reduced flaw densities. Better interpretation of NDE indications also was an important factor in reducing repair frequency.

The construction records document the defects and repairs in the reactor pressure vessels.

Specifications were in place for the portions of the vessel that were to be inspected, the time(s) during manufacture for inspections to be conducted, the amount of the vessel surface preparation to be performed, and the essential variables of the test to be performed. Test and inspection results were included in the vessel's construction records.

Complete construction records were obtained by PNNL for the RPVs from the PVRUF, River Bend Unit 2, and Hope Creek Unit 2. Partial construction records were obtained for the Shoreham RPV. Work on the Shoreham weldments was a collaborative effort with the Electric Power Research Institute (EPRI) NDE Center and Baltimore Gas \& Electric Company (BGE). BGE obtained some construction records from Combustion Engineering (CE) when BGE purchased the RPV weldments from the Shoreham Nuclear Power Station. Because these records are incomplete, they are not included in this report. A description of the Shoreham construction records obtained by BGE can be found in Schuster et al. (1999).

Figure 2.1 shows the types of construction records used for the PVRUF vessel to record the defects requiring repair. For the PVRUF vessel, five data collections (shown as database tables in Figure 2.1) contain the relevant information-nuclear shop travelers, inspection records, rejection notices, radiographic acceptance forms, and charts of (repair) cavities. These data collections have unique record identifiers (JobAndControlID, InspectionRecordID, RejectionNoticeID, and SeamID) except for the chart of cavities data collection, which shares its record identifier (TicketID) with that of the inspection records collection. The nuclear shop traveler indexes all other records in that they refer to the traveler ID. 


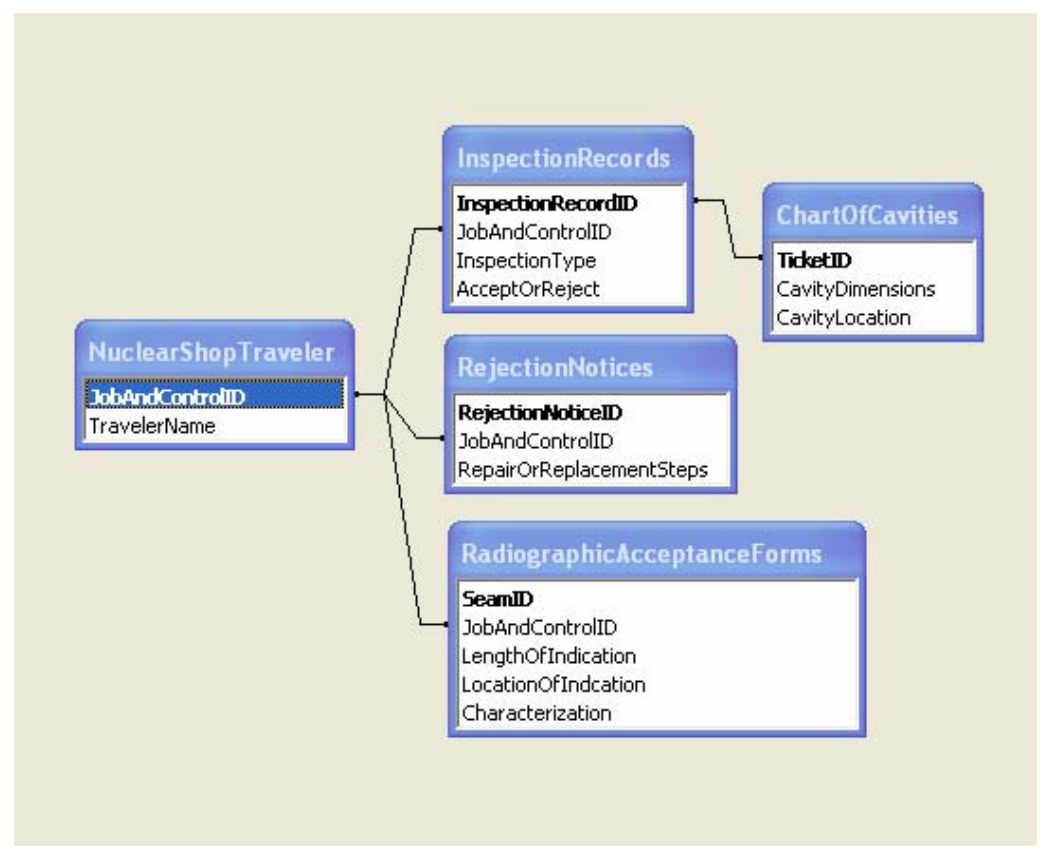

\section{Figure 2.1 Repair Record Types, Fields, and Relationships from Construction Records of PVRUF Reactor Pressure Vessel}

Various NDE methods were used during fabrication that might detect unacceptable conditions and initiate repair work. In some cases, NDE examinations were more rigorous than the minimum ASME Code requirements in effect at the time. The following examinations were conducted in accordance with written procedures to determine the frequency of repair to the vessels: dye penetrant testing of the clad surface, magnetic particle testing of weld preparation surfaces and the surfaces of the completed vessel assembly, and ultrasonic and radiographic testing of the welds.

These techniques were applied to ensure that unacceptable conditions were located, evaluated, and repaired at specified time(s) during vessel construction. Repaired areas were examined with radiographic testing (RT) and ultrasonic testing (UT).

For each vessel studied, the defects reported by NDE are listed in one table, followed by a second table providing repair information that corresponds to that defect. The defect table gives the defect type (if reported), the NDE method that found the defect, the length of the indication (if reported), and the major repair (MR) number associated with the defect. Figure 2.2 shows the numbering system for the welds in the PVRUF vessel assembly. This diagram is useful for the interpretation of the repair records, and this weld numbering system is used in the tables of this section when they refer to the PVRUF vessel. Figure 2.3 shows the RPV repair records and their relationships for Hope Creek 2 and River Bend 2.

The repair information tables list the cavity dimensions for each of the major repairs. From the cavity dimensions, the cavity surface area and volume can be estimated. The volume of a cavity is useful for estimating the amount of the repair metal as one of the product forms in the vessel. The bounding volume is obtained from the product of the cavity dimensions. The corrected volume is two-thirds of the bounding volume, a number obtained from the six repairs examined by PNNL. The bounding surface 


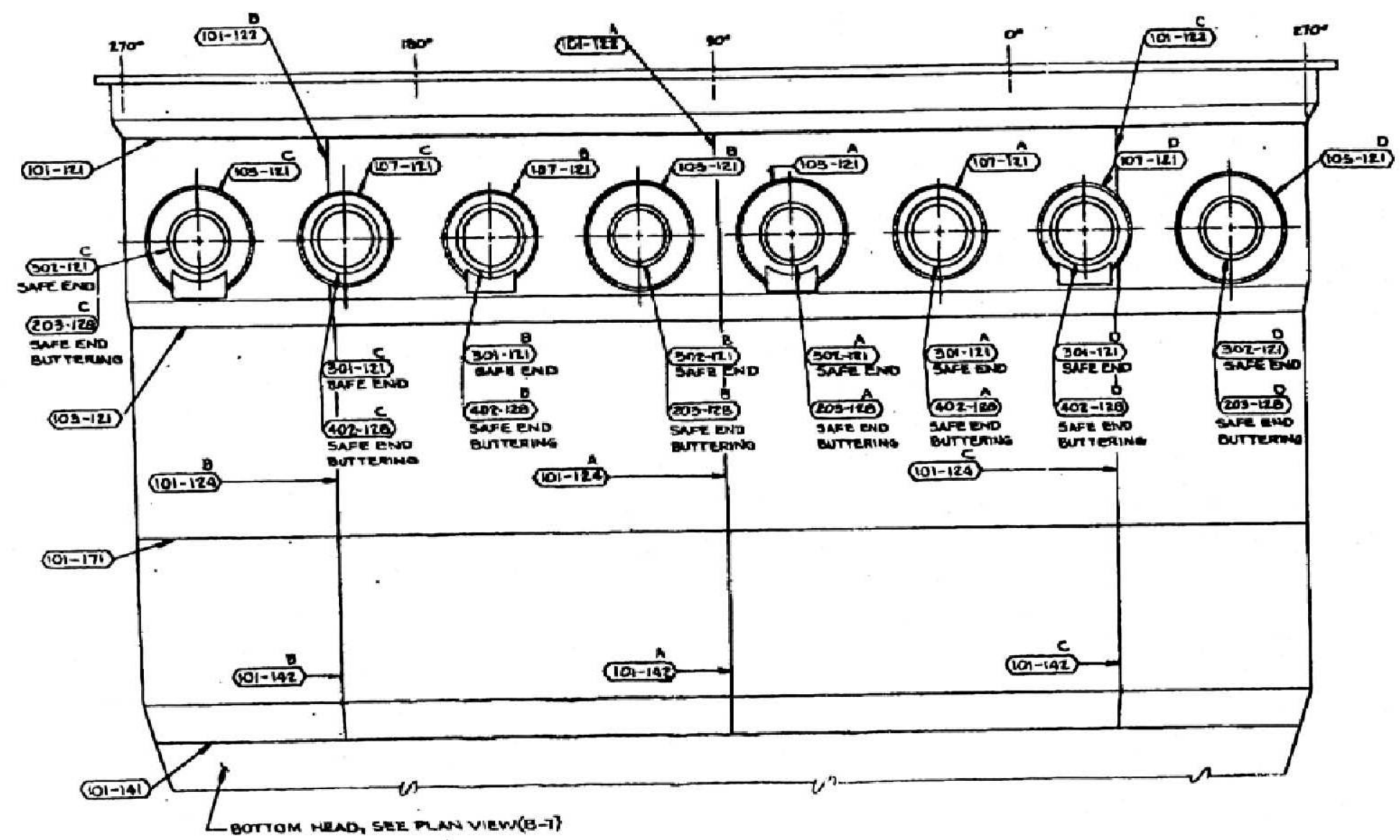

Figure 2.2 Roll-Out Diagram for Seam Welds in PVRUF Reactor Pressure Vessel Showing Weld Identification Numbers 


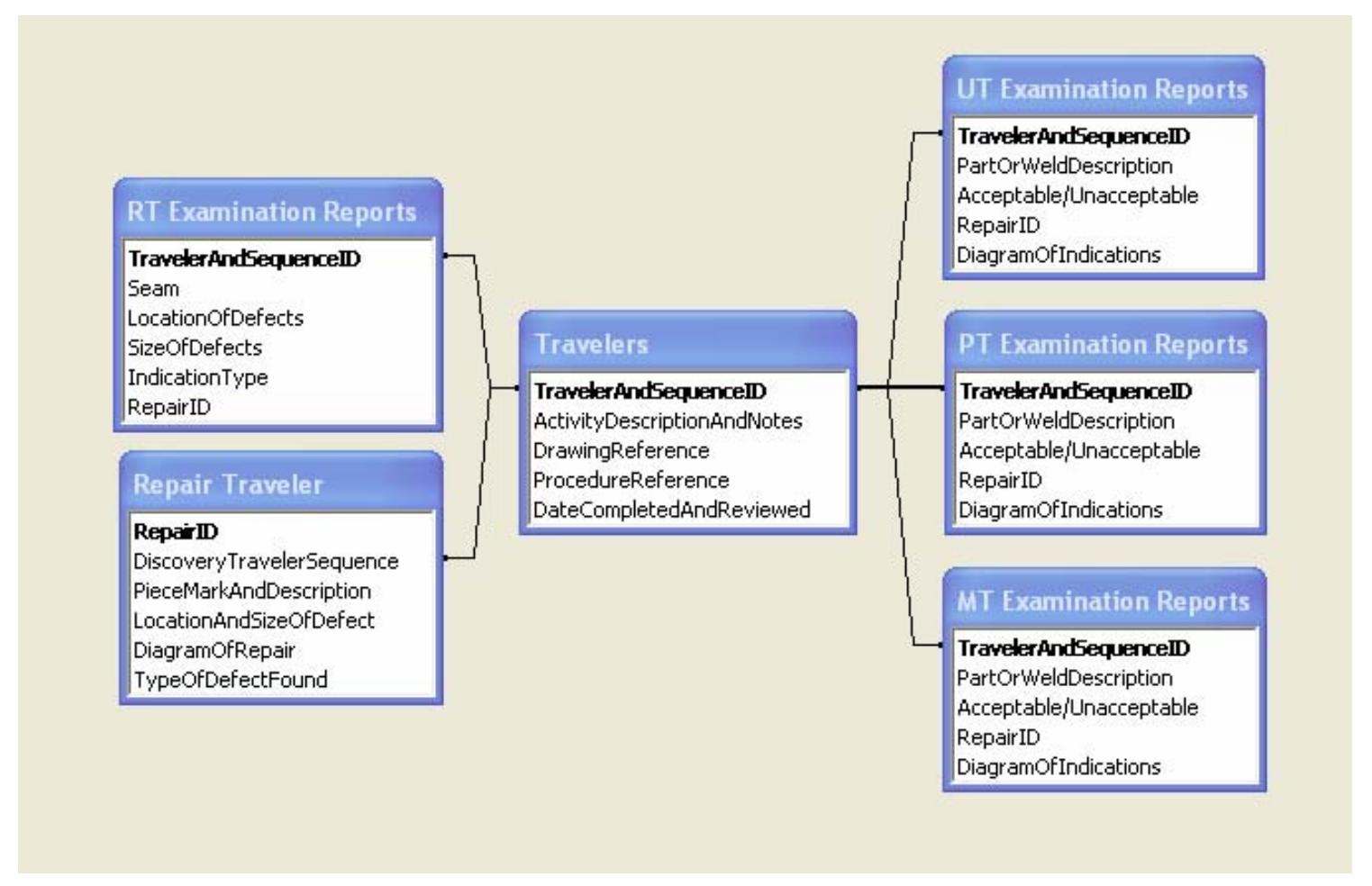

Figure 2.3 Hope Creek Unit 2 and River Bend Unit 2 Reactor Pressure Vessel Repair Records and Their Relationships

area is the sum of the surface areas of the sides of the bounding volume, and the corrected surface area is that of one-half of a stretched ellipsoid within the bounding surface. The surface area of the repairs is useful for normalizing fabrication flaw frequency data because the flaws are concentrated mostly in the fusion zone of the repair with the surrounding metal.

\subsection{RPV Cladding Defects and Repairs}

The construction records reported that dye penetrant testing (PT) found defects in the bottom head cladding, shell cladding, and nozzle cladding of the vessels. One RT defect was reported in the cladding of the River Bend Unit 2 vessel. RT was performed routinely before application of the cladding and, in this special case of an RT indication in the cladding, was part of a repair sequence for a seam weld defect.

The length of the defects found by PT (where reported) can be compared to the length of the repair cavities to show that the defects were sometimes longer than the length on the cladding surface. The repair cavities were lengthened so as to completely remove the defects. The depths of the defects can be estimated in a similar way, where the thickness of the cladding is 0.5 to $0.6 \mathrm{~cm}$. The repair tables show that some of the defects were through a single layer of cladding.

Table 2.1 provides an overview of the cladding repair information for the three vessels where PNNL's construction records were complete-PVRUF, Hope Creek Unit 2, and River Bend Unit 2. The information tables are listed in Table 2.1 for the separate subassemblies of the vessels. For example, Tables 2.7 and 2.8 contain the repair information on the nozzle cladding of the Hope Creek Unit 2 RPV. 
From the construction records, Table 2.2 lists the unsatisfactory inspections that required repair in the cladding of the bottom head of the PVRUF vessel. Table 2.3 lists the unsatisfactory inspections that required repair in the cladding of the shell of the PVRUF vessel. A chart of cavities was not generated for these repairs.

From the construction records, Table 2.4 lists the cladding defects reported in the bottom head of the Hope Creek Unit 2 RPV. Seven defects were found by PT, and the lengths of these surface indications are given in Table 2.4. The MR number is used to preserve the defect identity given in the construction records. Table 2.5 gives the estimated surface area and volume, using the MR number from Table 2.4 to identify the defect, and then gives the final cavity dimensions. The cavity lengths are sometimes significantly greater than the indication lengths reported by the PT. This can be explained by the length of the defect being longer in the subsurface than it was breaking the surface.

Tables 2.6 and 2.7 list the cladding defects reported in the shell of the Hope Creek Unit 2 RPV. Sixteen defects were found by PT. The defects were characterized in the construction records as slag. No length information was recorded for these surface indications.

Table 2.8 lists the cladding defects reported in the nozzles of the Hope Creek Unit 2 RPV. Five defects were found by PT. Three lengths of these surface indications are given in the table. In the construction records, four of the defects were characterized as porosity and one as a slag inclusion. Table 2.9 gives the final estimated cavity dimensions. Cavity length 1 is the same as the indication length at $1.9 \mathrm{~cm}$. Two of the cavities are more than twice as long as the PT indications. The cavity lengths can be taken as indicative of the length of the defect that was exposed during deepening of the cavity.

Table 2.10 lists the cladding defects reported in the shell of the River Bend Unit 2 RPV. Two defects were found by PT and one by RT. Two of the defects were characterized in the construction records as slag. No length information was recorded for these surface indications. The MR number is used to preserve the defect identity. Table 2.11 gives the estimated surface area and volume. The length of the RT indication is unusually large at $26.7 \mathrm{~cm}$.

Figure 2.4 shows a comparison of the cladding repairs length distributions for the Hope Creek Unit 2 and River Bend Unit 2 RPVs. Changes in the weld procedure specification, the quality of the base metal, and other factors may explain the different defect densities in the cladding for the two vessels. Figure 2.5 shows a comparison of estimated repair frequency in the cladding of the PVRUF, Hope Creek Unit 2, and River Bend Unit 2 RPVs. The earlier vessel, Hope Creek Unit 2 RPV, had many more repairs to the cladding than the PVRUF and River Bend Unit 2 RPVs, which were fabricated later.

Table 2.1 Construction Record Contents for Repairs in Cladding of Three Reactor Pressure Vessels

\begin{tabular}{||l|l|l|l||}
\hline & PVRUF & Hope Creek Unit 2 & River Bend Unit 2 \\
\hline Bottom head & Table 2.1 & Tables 2.3 and 2.4 & (None) \\
\hline Top head & (None) & (None) & (None) \\
\hline Shell & Table 2.2 & Tables 2.5 and 2.6 & Tables 2.9 and 2.10 \\
\hline Nozzles & (None) & Tables 2.7 and 2.8 & (None) \\
\hline
\end{tabular}


Table 2.2 Unsatisfactory Inspections (Requiring Repair) in Cladding of the Bottom Head of the PVRUF RPV

\begin{tabular}{|c|c|c|c|c|c||}
\hline No. & NDE & $\begin{array}{c}\text { Defect } \\
\text { Type }\end{array}$ & $\begin{array}{c}\text { Length } \\
\text { (cm) }\end{array}$ & $\begin{array}{c}\text { Inspection } \\
\text { ID }\end{array}$ & Job ID \\
\hline 1 & PT & (Not given) & (Not given) & A-139685 & $750151-040$ \\
\hline
\end{tabular}

Table 2.3 Unsatisfactory Inspections (Requiring Repair) in Cladding in the Shell of the PVRUF RPV

\begin{tabular}{||c|c|c|c|c|c||}
\hline No. & NDE & $\begin{array}{c}\text { Defect } \\
\text { Type }\end{array}$ & $\begin{array}{c}\text { Length } \\
\text { (cm) }\end{array}$ & $\begin{array}{c}\text { Inspection } \\
\text { ID }\end{array}$ & Job ID \\
\hline 1 & PT & (Not given) & (Not given) & A-003908 & $750141-005$ \\
\hline 2 & PT & (Not given) & (Not given) & A-013596 & $750171-085$ \\
\hline
\end{tabular}

Table 2.4 Cladding Defects in the Bottom Head of the Hope Creek Unit 2 RPV

\begin{tabular}{|c|c|c|c|c||}
\hline \hline No. & NDE & $\begin{array}{c}\text { Defect } \\
\text { Type }\end{array}$ & $\begin{array}{c}\text { Length } \\
\text { (cm) }\end{array}$ & Repair ID \\
\hline 1 & PT & (Not given) & 5.1 & MR-14A \\
\hline 2 & PT & (Not given) & 5.1 & MR-14B \\
\hline 3 & PT & (Not given) & 3.2 & MR-42B \\
\hline 4 & PT & (Not given) & 5.1 & MR-14C \\
\hline 5 & PT & (Not given) & 6.4 & MR-42A \\
\hline 6 & PT & (Not given) & 6.4 & MR-14D \\
\hline 7 & PT & (Not given) & 5.1 & MR-14E \\
\hline
\end{tabular}

Table 2.5 Estimated Surface Area and Volume of Cladding Repairs in the Bottom Head of the Hope Creek Unit 2 RPV

\begin{tabular}{|c|c|c|c|c|c|c|c|c|}
\hline & & \multicolumn{3}{|c|}{ Cavity Dimensions } & \multicolumn{2}{|c|}{ Volume } & \multicolumn{2}{|c|}{ " Surface Area } \\
\hline \multicolumn{2}{|c|}{ Repair ID } & $\begin{array}{l}\text { Length } \\
\text { (cm) }\end{array}$ & $\begin{array}{l}\text { Width } \\
\text { (cm) }\end{array}$ & $\begin{array}{l}\text { Depth } \\
\text { (cm) }\end{array}$ & $\begin{array}{c}\text { Bounding } \\
\left(\mathrm{cm}^{3}\right)\end{array}$ & $\begin{array}{c}\text { Corrected } \\
\left(\mathrm{cm}^{3}\right)\end{array}$ & $\begin{array}{c}\text { Bounding } \\
\left(\mathrm{cm}^{2}\right)\end{array}$ & $\begin{array}{c}\text { Corrected } \\
\left(\mathrm{cm}^{2}\right)\end{array}$ \\
\hline 1 & MR-14A & 5.1 & 0.6 & 0.5 & 1.5 & 1.0 & 8.8 & 5.1 \\
\hline 2 & MR-14B & 5.7 & 0.6 & 0.5 & 1.7 & 1.1 & 9.7 & 5.7 \\
\hline 3 & MR-42B & 5.1 & 1.3 & 0.5 & 3.3 & 2.2 & 13.0 & 7.4 \\
\hline 4 & MR-14C & 6.4 & 1.3 & 0.6 & 5.0 & 3.3 & 17.6 & 10.1 \\
\hline 5 & MR-42A & 15.2 & 1.9 & 0.6 & 17.3 & 11.6 & 49.4 & 29.4 \\
\hline 6 & MR-14D & 25.4 & 1.3 & 0.3 & 9.9 & 6.6 & 49.0 & 30.3 \\
\hline 7 & MR-14E & 29.2 & 1.3 & 0.3 & 11.4 & 7.6 & 56.3 & 34.8 \\
\hline
\end{tabular}


Table 2.6 Cladding Defects in the Shell of the Hope Creek Unit 2 RPV

\begin{tabular}{|c|c|c|c|c||}
\hline \hline No. & NDE & $\begin{array}{c}\text { Defect } \\
\text { Type }\end{array}$ & $\begin{array}{c}\text { Length } \\
\text { (cm) }\end{array}$ & Repair ID \\
\hline 1 & PT & Slag & (Not given) & MR-114B \\
\hline 2 & PT & Slag & (Not given) & MR-114D \\
\hline 3 & PT & Slag & (Not given) & MR-114F \\
\hline 4 & PT & Slag & (Not given) & MR-93A \\
\hline 5 & PT & Slag & (Not given) & MR-93K \\
\hline 6 & PT & Slag & (Not given) & MR-93F \\
\hline 7 & PT & Slag & (Not given) & MR-93C \\
\hline 8 & PT & Slag & (Not given) & MR-93D \\
\hline 9 & PT & Slag & (Not given) & MR-93H \\
\hline 10 & PT & Slag & (Not given) & MR-93E \\
\hline 11 & PT & Slag & (Not given) & MR-114C \\
\hline 12 & PT & Slag & (Not given) & MR-114A \\
\hline 13 & PT & Slag & (Not given) & MR-93G \\
\hline 14 & PT & Slag & (Not given) & MR-114E \\
\hline 15 & PT & Slag & (Not given) & MR-93B \\
\hline 16 & PT & Slag & (Not given) & MR-93J \\
\hline
\end{tabular}

Table 2.7 Estimated Surface Area and Volume of Cladding Repairs in the Shell of the Hope Creek Unit 2 RPV

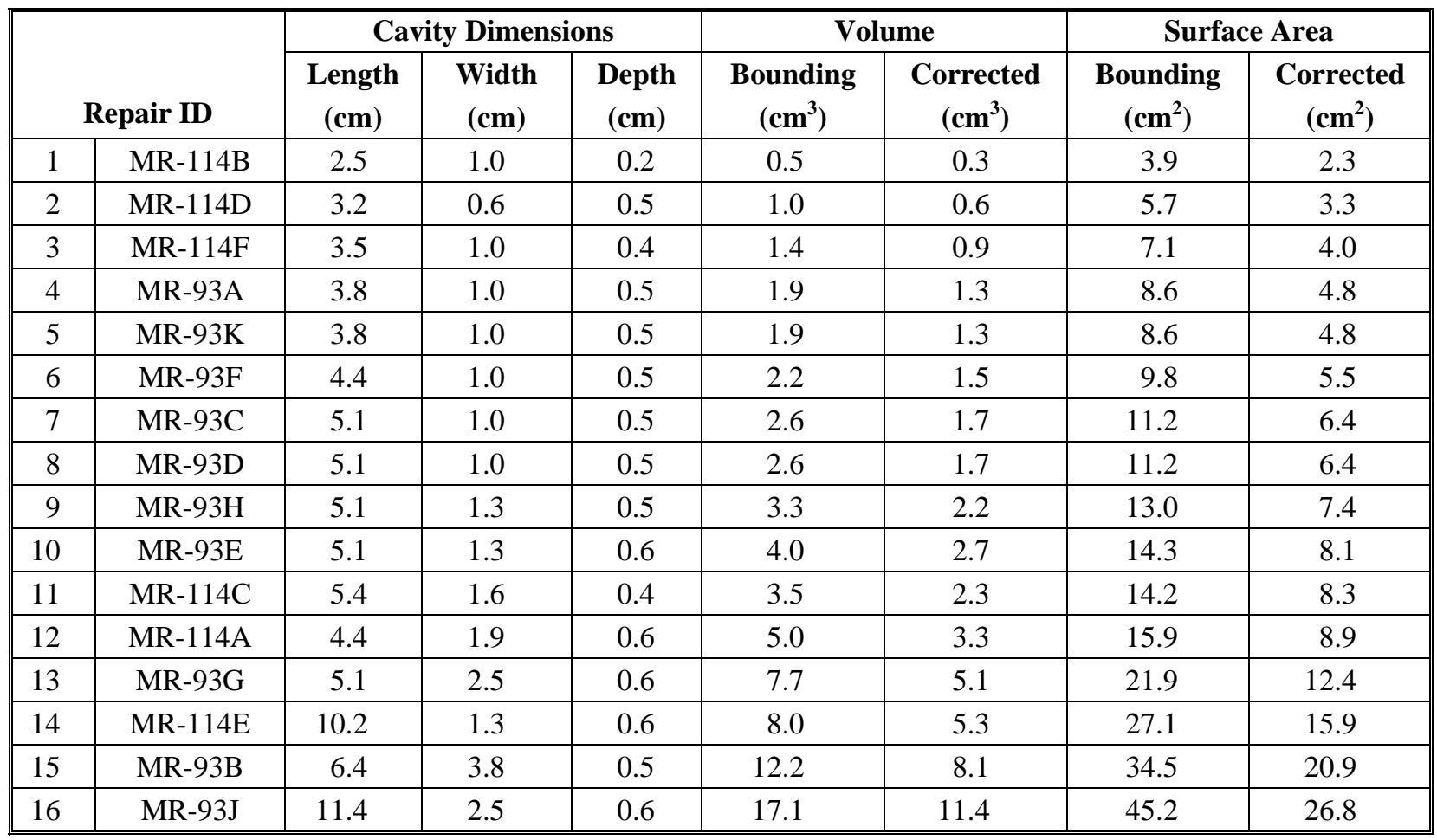


Table 2.8 Cladding Defects in the Nozzles of the Hope Creek Unit 2 RPV

\begin{tabular}{||c|c|l|l|c||}
\hline \hline No. & NDE & $\begin{array}{c}\text { Defect } \\
\text { Type }\end{array}$ & $\begin{array}{c}\text { Length } \\
(\mathbf{c m})\end{array}$ & Repair ID \\
\hline 1 & PT & Porosity & 1.9 & MR-20C \\
\hline 2 & PT & Porosity & (Not given) & MR-20D \\
\hline 3 & PT & Porosity & 1.9 & MR-20B \\
\hline 4 & PT & Porosity & 1.9 & MR-20A \\
\hline 5 & PT & Slag inclusions & (Not given) & MR-118 \\
\hline
\end{tabular}

Table 2.9 Estimated Surface Area and Volume of Cladding Repairs in the Nozzles of the Hope Creek Unit 2 RPV

\begin{tabular}{|c|c|c|c|c|c|c|c|c|}
\hline & & \multicolumn{3}{|c|}{ Cavity Dimensions } & \multicolumn{2}{|c|}{ Volume } & \multicolumn{2}{|c|}{ Surface Area } \\
\hline \multicolumn{2}{|c|}{ Repair ID } & $\begin{array}{c}\text { Length } \\
\text { (cm) }\end{array}$ & $\begin{array}{c}\text { Width } \\
\text { (cm) }\end{array}$ & $\begin{array}{c}\text { Depth } \\
\text { (cm) }\end{array}$ & $\begin{array}{c}\text { Bounding } \\
\left(\mathrm{cm}^{3}\right)\end{array}$ & $\begin{array}{c}\text { Corrected } \\
\left(\mathrm{cm}^{3}\right)\end{array}$ & $\begin{array}{c}\text { Bounding } \\
\left(\mathrm{cm}^{2}\right)\end{array}$ & $\begin{array}{c}\text { Corrected } \\
\left(\mathrm{cm}^{2}\right)\end{array}$ \\
\hline 1 & MR-20C & 1.9 & 0.6 & 0.2 & 0.2 & 0.2 & 2.1 & 1.2 \\
\hline 2 & MR-20D & 5.1 & 1.9 & 0.6 & 5.8 & 3.9 & 18.1 & 10.2 \\
\hline 3 & MR-20B & 4.4 & 2.5 & 0.5 & 5.5 & 3.7 & 17.9 & 10.3 \\
\hline 4 & MR-20A & 5.1 & 2.9 & 0.6 & 8.9 & 5.9 & 24.4 & 13.9 \\
\hline 5 & MR-118 & 14.0 & 0.6 & 0.6 & 5.0 & 3.4 & 25.9 & 15.8 \\
\hline
\end{tabular}

Table 2.10 Cladding Defects in the Shell of the River Bend Unit 2 RPV

\begin{tabular}{||c|c|c|c|c||}
\hline No. & NDE & $\begin{array}{c}\text { Defect } \\
\text { Type }\end{array}$ & $\begin{array}{c}\text { Length } \\
\text { (cm) }\end{array}$ & Repair ID \\
\hline 1 & PT & Slag & (Not given) & MR-56 \\
\hline 2 & PT & (Not given) & (Not given) & MR-58 \\
\hline 3 & RT & Slag & (Not given) & MR-11B \\
\hline
\end{tabular}

Table 2.11 Estimated Surface Area and Volume of Cladding Repairs in the Shell of the River Bend Unit 2 RPV

\begin{tabular}{|c|c|c|c|c|c|c|c|c|}
\hline \multirow{2}{*}{\multicolumn{2}{|c|}{ Repair ID }} & \multicolumn{3}{|c|}{ Cavity Dimensions } & \multicolumn{2}{|c|}{ Volume } & \multicolumn{2}{|c|}{ Surface Area } \\
\hline & & $\begin{array}{c}\text { Length } \\
\text { (cm) }\end{array}$ & $\begin{array}{c}\text { Width } \\
\text { (cm) }\end{array}$ & $\begin{array}{c}\text { Depth } \\
\text { (cm) }\end{array}$ & $\begin{array}{c}\text { Bounding } \\
\left(\mathrm{cm}^{3}\right)\end{array}$ & $\begin{array}{c}\text { Corrected } \\
\left(\mathrm{cm}^{3}\right)\end{array}$ & $\begin{array}{c}\text { Bounding } \\
\left(\mathrm{cm}^{2}\right)\end{array}$ & $\begin{array}{c}\text { Corrected } \\
\left(\mathrm{cm}^{2}\right)\end{array}$ \\
\hline 1 & MR-56 & 5.1 & 1.0 & 0.6 & 3.1 & 2.0 & 12.4 & 7.1 \\
\hline 2 & MR-58 & 12.7 & 2.5 & 0.6 & 19.1 & 12.7 & 50.0 & 29.8 \\
\hline 3 & MR-11B & 26.7 & 3.8 & 0.5 & 50.7 & 33.8 & 132.0 & 84.9 \\
\hline
\end{tabular}




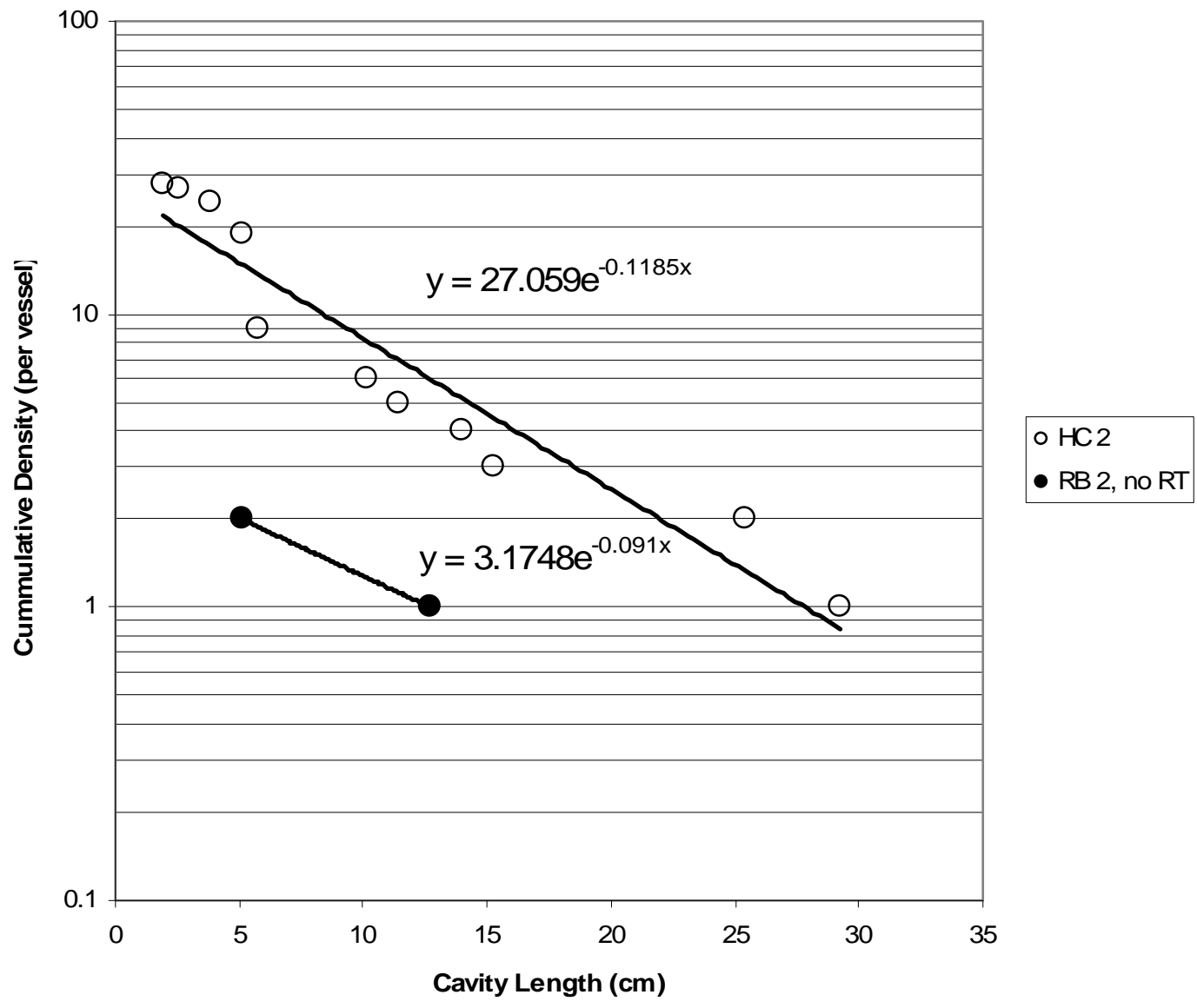

Figure 2.4 Comparison of Cavity Length of Cladding Repairs in the Hope Creek Unit 2 and River Bend Unit 2 RPVs

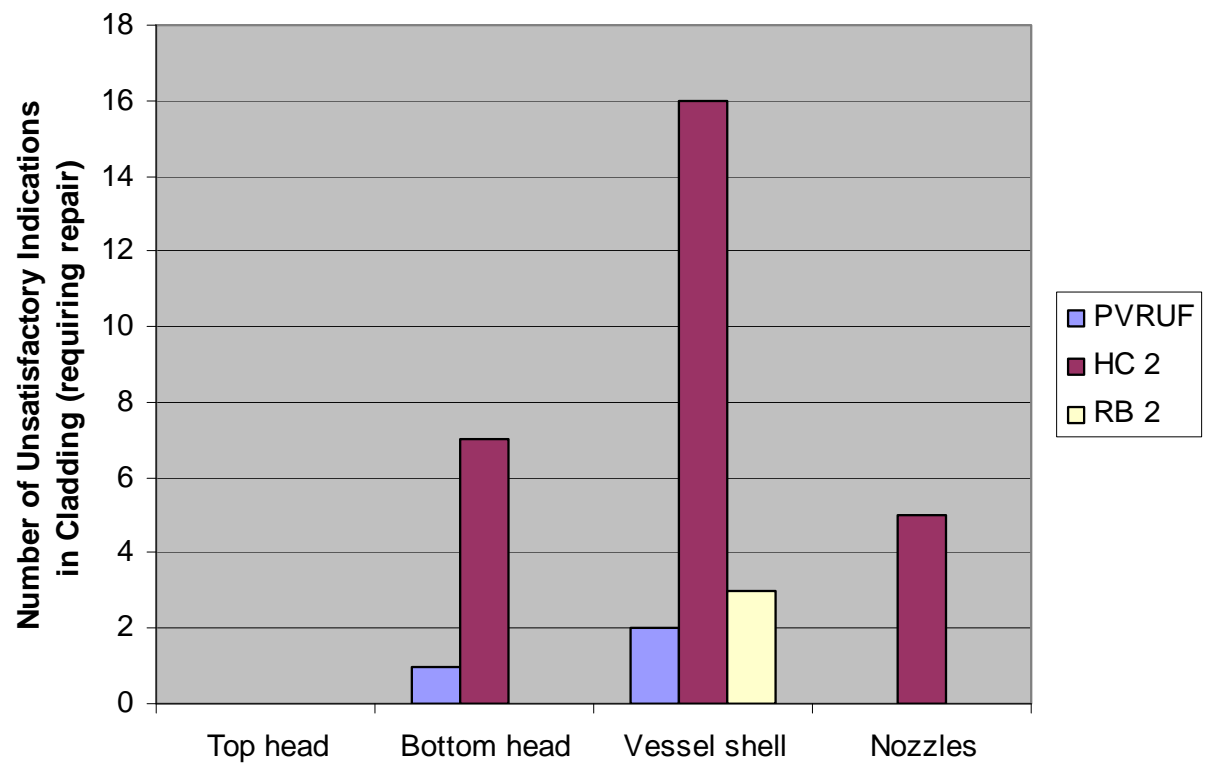

Figure 2.5 Comparison of Estimated Repair Frequency in the Cladding of Three RPVs 


\subsection{RPV Base Metal Defects and Repairs}

The base metal plate vendors and the nozzle forging vendors reported more than 30 surface defects and no mid-wall laminations to the vessel manufacturer. The vessel manufacturers performed additional inspection that added to the list of surface defects requiring repair by welding.

Thirty-two surface defects were found by vendors and the vessel manufacturer in the base metal plates and in the nozzles of the Hope Creek Unit 2 vessel. Six unsatisfactory inspections with magnetic particle testing found indications requiring repair in the base metal of the PVRUF vessel. Eleven repair cavities were reported in the nozzle forgings of the PVRUF vessel. One defect was found in a base metal plate of the top head of the River Bend Unit 2 vessel.

Table 2.12 provides an overview of the base metal repair information for the three RPVs. The information tables are listed in Table 2.12 for the separate subassemblies of the vessels. The bottom head, top head, and shell were bent plate. The nozzles were forgings.

Tables 2.13 and 2.14 list the unsatisfactory inspections of the base metal in the top head and shell of the PVRUF RPV. These four magnetic particle test indications were recorded as unsatisfactory, but no flaw type or flaw length information was given in the construction records.

Table 2.15 lists the base metal defects reported in the nozzles of the PVRUF RPV. These unsatisfactory indications resulted in eleven entries into the chart of cavities records as separate repairs. Table 2.16 gives the cavity dimension data from the construction records with estimated surface area and volume for these repairs to the base metal of the nozzle forgings in the PVRUF RPV.

Table 2.17 lists the base metal defects reported in the bottom head of Hope Creek Unit 2 RPV. Fifteen defects were found on the surfaces of the base metal plates of the bottom head. The construction records characterized two of the defects as scabs and the rest as either plate defect or surface defect. The defects were found by the plate vendor (mill) or by visual inspection at the vessel manufacturer. Table 2.18 gives the estimated surface area and volume, identifies the defect by MR number from Table 2.17, and then gives the surface, outside or inside, on which the defect was located. The final cavity dimensions are listed with the volume and surface area of the cavity. The depths of the cavities were less than about a centimeter, indicating that the defects were isolated to the surface of the plates and that mid-wall segregates (laminations) were not being called defects, so no repair was made.

Table 2.19 lists the base metal defects reported in the shell of Hope Creek Unit 2 RPV. Fifteen defects were found on the surfaces of the base metal plates of the vessel shell. The construction records characterized them as surface defects. Table 2.20 gives the estimated surface area and volume. Most of the defects were on the inside of the plate or ring assembly, and all of the defects were shallow, with depths of less than or equal to a centimeter.

Table 2.21 gives the base metal defects reported in the nozzles of Hope Creek Unit 2 RPV. Table 2.22 lists the estimated surface area and volume. The defects were up to $2.5 \mathrm{~cm}$ deep and were found on the outside of the nozzle forging.

Table 2.23 lists the single base metal defects reported in the top head of the River Bend Unit 2 RPV. The defect, found before the top head was assembled, was detected by magnetic particle testing (MT). 
Table 2.24 gives the estimated repair surface area and volume. The repair cavity was small, approximately $1 \mathrm{~cm}^{3}$ in volume.

Figure 2.6 shows a comparison of base metal repairs principal axis (length) distributions in the Hope Creek Unit 2 and River Bend Unit 2 RPVs. Most of the difference in the defect densities in the base metal for the two vessels can be explained by changes in the quality of the base metal. Other factors (such as NDE of base metal) may contribute to the defect densities in the base metal for the two vessels. Figure 2.7 shows a comparison of estimated repair frequency in the base metal of the three RPVs. The 11 repairs to the base metal of the nozzle forgings of the PVRUF RPV is an interesting case of a repair frequency unusually high for a more recently manufactured vessel.

Table 2.12 Construction Record Contents for Repairs in Base Metal of Three Reactor Pressure Vessels

\begin{tabular}{||l|l|l|l||}
\hline & PVRUF & Hope Creek Unit 2 & River Bend Unit 2 \\
\hline Bottom head & (None) & Tables 2.17 and 2.18 & (None) \\
\hline Top head & Table 2.13 & (None) & Tables 2.23 and 2.24 \\
\hline Shell & Table 2.14 & Tables 2.19 and 2.20 & (None) \\
\hline Nozzles & Tables 2.15 and 2.16 & Tables 2.21 and 2.22 & (None) \\
\hline
\end{tabular}

Table 2.13 Unsatisfactory Inspections (Requiring Repair) in Base Metal of Top Head of the PVRUF RPV

\begin{tabular}{||c|c|c|c|c|c||}
\hline \hline No. & NDE & $\begin{array}{c}\text { Defect } \\
\text { Type }\end{array}$ & $\begin{array}{c}\text { Length } \\
\text { (cm) }\end{array}$ & $\begin{array}{c}\text { Inspection } \\
\text { ID }\end{array}$ & Job ID \\
\hline 1 & MT & (Not given) & (Not given) & A-007162 & $750101-075$ \\
\hline 2 & MT & (Not given) & (Not given) & A-006125 & $750101-030$ \\
\hline
\end{tabular}

Table 2.14 Unsatisfactory Inspections (Requiring Repair) in Base Metal of Shell of the PVRUF RPV

\begin{tabular}{|c|c|c|c|c|c||}
\hline No. & NDE & $\begin{array}{c}\text { Defect } \\
\text { Type }\end{array}$ & $\begin{array}{c}\text { Length } \\
\text { (cm) }\end{array}$ & $\begin{array}{c}\text { Inspection } \\
\text { ID }\end{array}$ & Job ID \\
\hline 1 & MT & (Not given) & (Not given) & A-086332 & $750124-080$ \\
\hline 2 & MT & (Not given) & (Not given) & A-103533 & $750142-080$ \\
\hline
\end{tabular}

Table 2.15 Unsatisfactory Inspections (Requiring Repair) in Base Metal of Nozzles of the PVRUF RPV

\begin{tabular}{||c|c|c|c|c|c||}
\hline No. & NDE & $\begin{array}{c}\text { Defect } \\
\text { Type }\end{array}$ & $\begin{array}{c}\text { Length } \\
\text { (cm) }\end{array}$ & Inspection ID & Job ID \\
\hline 1 & MT & (Not given) & (Not given) & A-017723 & $750171-085$ \\
\hline 2 & MT & (Not given) & (Not given) & A-014361 & RN 3024-080 \\
\hline
\end{tabular}


Table 2.16 Estimated Surface Area and Volume of Base Metal Repairs in the Nozzles of the PVRUF RPV

\begin{tabular}{|c|c|c|c|c|c|c|c|c|}
\hline \multirow[b]{2}{*}{ No. } & \multirow[b]{2}{*}{ Nozzle } & \multicolumn{3}{|c|}{ "Cavity Dimensions } & \multicolumn{2}{|c|}{ Volume } & \multicolumn{2}{|c|}{ Surface Area } \\
\hline & & $\begin{array}{c}\text { Length } \\
\text { (cm) }\end{array}$ & $\begin{array}{c}\text { Width } \\
\text { (cm) }\end{array}$ & $\begin{array}{c}\text { Depth } \\
\text { (cm) }\end{array}$ & $\begin{array}{c}\text { Bounding } \\
\left(\mathrm{cm}^{3}\right)\end{array}$ & \begin{tabular}{|c|} 
Corrected \\
$\left(\mathrm{cm}^{3}\right)$
\end{tabular} & $\begin{array}{c}\text { Bounding } \\
\left(\mathrm{cm}^{2}\right)\end{array}$ & $\begin{array}{c}\text { Corrected } \\
\left(\mathrm{cm}^{2}\right)\end{array}$ \\
\hline 1 & $107-121 \mathrm{C}$ & 4.1 & 1.3 & 0.5 & 2.7 & 1.8 & 10.7 & 6.0 \\
\hline 2 & $107-121 \mathrm{C}$ & 3.6 & 1.8 & 0.5 & 3.2 & 2.2 & 11.9 & 6.6 \\
\hline 3 & $107-121 \mathrm{C}$ & 5.1 & 3.3 & 0.5 & 8.4 & 5.6 & 25.2 & 14.9 \\
\hline 4 & $107-121 \mathrm{C}$ & 11.4 & 1.3 & 0.3 & 4.4 & 3.0 & 22.4 & 13.7 \\
\hline 5 & $107-121 \mathrm{C}$ & 5.3 & 1.0 & 0.3 & 1.6 & 1.1 & 9.1 & 5.3 \\
\hline 6 & $107-121 \mathrm{C}$ & 2.8 & 2.3 & 0.5 & 3.2 & 2.1 & 11.5 & 6.4 \\
\hline 7 & $107-121 \mathrm{C}$ & 15.2 & 1.0 & 0.3 & 4.6 & 3.0 & 24.9 & 15.1 \\
\hline 8 & $107-121 \mathrm{C}$ & 3.6 & 1.0 & 0.3 & 1.1 & 0.7 & 6.4 & 3.7 \\
\hline 9 & 107-121B & 15.5 & 1.3 & 0.5 & 10.1 & 6.7 & 37.0 & 22.2 \\
\hline 10 & $107-121 \mathrm{~A}$ & 2.8 & 0.8 & 0.5 & 1.1 & 0.7 & 5.8 & 3.2 \\
\hline 11 & $107-121 \mathrm{~A}$ & 2.8 & 0.8 & 0.5 & 1.1 & 0.7 & 5.8 & 3.2 \\
\hline
\end{tabular}

Table 2.17 Base Metal Defects in the Bottom Head of the Hope Creek Unit 2 RPV

\begin{tabular}{|c|l|l|l|c||}
\hline No. & \multicolumn{1}{|c|}{ NDE } & \multicolumn{1}{c|}{$\begin{array}{c}\text { Defect } \\
\text { Type }\end{array}$} & $\begin{array}{c}\text { Length } \\
\text { (cm) }\end{array}$ & Repair ID \\
\hline 1 & (Visual) & Plate defect & (Not given) & MR-78E \\
\hline 2 & (Visual) & Scab & (Not given) & MR-77D \\
\hline 3 & (Visual) & Plate defect & (Not given) & MR-77A \\
\hline 4 & (Visual) & Plate defect & (Not given) & MR-77C \\
\hline 5 & (Visual) & Scab & (Not given) & MR-77B \\
\hline 6 & (Visual) & Plate defect & (Not given) & MR-78D \\
\hline 7 & (Mill) & Surface defect & (Not given) & MR-3F \\
\hline 8 & (Mill) & Surface defect & (Not given) & MR-4B \\
\hline 9 & (Mill) & Surface defect & (Not given) & MR-4C \\
\hline 10 & (Mill) & Surface defect & (Not given) & MR-3B \\
\hline 11 & (Mill) & Surface defect & (Not given) & MR-3D \\
\hline 12 & (Mill) & Surface defect & (Not given) & MR-3E \\
\hline 13 & (Mill) & Surface defect & (Not given) & MR-4A \\
\hline 14 & (Mill) & Surface defect & (Not given) & MR-3C \\
\hline 15 & (Mill) & Surface defect & (Not given) & MR-3A \\
\hline \hline
\end{tabular}


Table 2.18 Estimated Surface Area and Volume of Base Metal Repair in the Bottom Head of the Hope Creek Unit 2 RPV

\begin{tabular}{|c|c|c|c|c|c|c|c|c|c|}
\hline \multirow[b]{2}{*}{ No. } & \multirow[b]{2}{*}{$\begin{array}{c}\text { Repair } \\
\text { ID }\end{array}$} & \multirow[b]{2}{*}{ ID/OD } & \multicolumn{3}{|c|}{ "Cavity Dimensions } & \multicolumn{2}{|c|}{ Volume } & \multicolumn{2}{|c|}{ Surface Area } \\
\hline & & & $\begin{array}{c}\text { Length } \\
\text { (cm) }\end{array}$ & $\begin{array}{c}\text { Width } \\
\text { (cm) }\end{array}$ & $\begin{array}{c}\text { Depth } \\
\text { (cm) }\end{array}$ & $\begin{array}{c}\text { Bounding } \\
\left(\mathrm{cm}^{3}\right)\end{array}$ & $\begin{array}{c}\text { Corrected } \\
\left(\mathrm{cm}^{3}\right)\end{array}$ & $\begin{array}{c}\text { Bounding } \\
\left(\mathrm{cm}^{2}\right)\end{array}$ & $\begin{array}{c}\text { Corrected } \\
\left(\mathrm{cm}^{2}\right)\end{array}$ \\
\hline 1 & MR-78E & OD & 7.6 & 1.3 & 0.2 & 2.0 & 1.3 & 13.4 & 8.4 \\
\hline 2 & MR-77D & OD & 3.8 & 3.2 & 0.2 & 2.4 & 1.6 & 15.0 & 9.9 \\
\hline 3 & MR-77A & OD & 4.4 & 3.2 & 0.4 & 5.6 & 3.8 & 20.2 & 12.1 \\
\hline 4 & MR-77C & OD & 5.7 & 3.2 & 0.5 & 9.1 & 6.1 & 27.1 & 16.1 \\
\hline 5 & MR-77B & OD & 15.2 & 1.9 & 0.3 & 8.7 & 5.8 & 39.1 & 24.7 \\
\hline 6 & MR-78D & OD & 8.9 & 5.1 & 0.2 & 9.1 & 6.1 & 51.0 & 36.1 \\
\hline 7 & MR-3F & OD & 7.6 & 6.4 & 0.3 & 14.6 & 9.7 & 57.0 & 39.0 \\
\hline 8 & MR-4B & ID & 7.6 & 7.6 & 0.5 & 28.9 & 19.3 & 73.0 & 47.2 \\
\hline 9 & MR-4C & ID & 12.7 & 7.6 & 0.8 & 77.2 & 51.5 & 129.0 & 80.8 \\
\hline 10 & MR-3B & OD & 14.0 & 14.0 & 1.0 & 196.0 & 130.7 & 252.0 & 161.1 \\
\hline 11 & MR-3D & OD & 50.8 & 5.1 & 0.6 & 155.4 & 103.6 & 326.2 & 214.0 \\
\hline 12 & MR-3E & OD & 38.1 & 7.6 & 1.0 & 289.6 & 193.0 & 381.0 & 242.9 \\
\hline 13 & MR-4A & ID & 28.6 & 10.8 & 0.6 & 185.3 & 123.6 & 356.2 & 247.1 \\
\hline 14 & MR-3C & OD & 63.5 & 7.6 & 0.8 & 386.1 & 257.4 & 596.4 & 395.4 \\
\hline 15 & MR-3A & OD & 111.8 & 7.6 & 1.1 & 934.6 & 623.1 & $1,112.4$ & 716.2 \\
\hline
\end{tabular}

Table 2.19 Base Metal Defects in the Shell of the Hope Creek Unit 2 RPV

\begin{tabular}{||c|l|l|c|c||}
\hline No. & \multicolumn{1}{|c|}{ NDE } & \multicolumn{1}{c|}{ Defect } & $\begin{array}{c}\text { Repair } \\
\text { LD }\end{array}$ \\
\hline 1 & (Not given) & Mill surface defect & (Not given) & MR-28 \\
\hline 2 & (Not given) & Mill surface defect & (Not given) & MR-5B \\
\hline 3 & (Not given) & Mill surface defect & (Not given) & MR-15 \\
\hline 4 & (Not given) & Surface defect on inside of plate & (Not given) & MR-30 \\
\hline 5 & (Not given) & Mill surface defect & (Not given) & MR-29 \\
\hline 6 & (Not given) & Mill surface defect & (Not given) & MR-9 \\
\hline 7 & (Not given) & Surface imperfection & (Not given) & MR-71A \\
\hline 8 & (Not given) & Mill surface defect & MR-27 \\
\hline 9 & (Not given) & Surface defect on inside of plate & (Not given) & MR-5D \\
\hline 10 & (Not given) & Surface defect on inside of plate & (Not given) & MR-5A \\
\hline 11 & (Not given) & Surface defect on inside of plate & (Not given) & MR-5C \\
\hline 12 & (Not given) & Surface defect on inside of plate & (Not given) & MR-5F \\
\hline 13 & (Not given) & Mill surface defect & (Not given) & MR-8 \\
\hline 14 & (Not given) & Surface defect on inside of plate & (Not given) & MR-5E \\
\hline 15 & (Not given) & Mill surface defect & (Not given) & MR-10 \\
\hline
\end{tabular}


Table 2.20 Estimated Surface Area and Volume of Base Metal Repair in the Shell of the Hope Creek Unit 2 RPV

\begin{tabular}{|c|c|c|c|c|c|c|c|c|c|}
\hline \multirow[b]{2}{*}{ No. } & \multirow[b]{2}{*}{$\begin{array}{l}\text { Repair } \\
\text { ID }\end{array}$} & \multirow[b]{2}{*}{ ID/OD } & \multicolumn{3}{|c|}{ "Cavity Dimensions } & \multicolumn{2}{|c|}{ Volume } & \multicolumn{2}{|c|}{ Surface Area } \\
\hline & & & $\begin{array}{c}\text { Length } \\
\text { (cm) }\end{array}$ & $\begin{array}{c}\text { Width } \\
\text { (cm) }\end{array}$ & $\begin{array}{c}\text { Depth } \\
\text { (cm) }\end{array}$ & $\begin{array}{c}\text { Bounding } \\
\left(\mathrm{cm}^{3}\right)\end{array}$ & \begin{tabular}{|c|c|} 
Corrected \\
$\left(\mathrm{cm}^{3}\right)$
\end{tabular} & $\begin{array}{c}\text { Bounding } \\
\left(\mathrm{cm}^{2}\right)\end{array}$ & $\begin{array}{c}\text { Corrected } \\
\left(\mathrm{cm}^{2}\right)\end{array}$ \\
\hline 1 & MR-28 & ID & 3.8 & 2.5 & 0.5 & 4.8 & 3.2 & 15.8 & 9.0 \\
\hline 2 & MR-5B & ID & 6.4 & 6.4 & 0.5 & 20.5 & 13.7 & 53.8 & 33.9 \\
\hline 3 & MR-15 & ID & 8.9 & 3.8 & 1.9 & 64.3 & 42.8 & 82.1 & 44.5 \\
\hline 4 & MR-30 & OD & 22.9 & 2.9 & 0.3 & 19.9 & 13.3 & 81.9 & 54.4 \\
\hline 5 & MR-29 & ID & 30.5 & 1.6 & 1.0 & 48.8 & 32.5 & 113.0 & 68.2 \\
\hline 6 & MR-9 & ID & 22.9 & 5.1 & 0.5 & 58.4 & 38.9 & 144.8 & 95.5 \\
\hline 7 & MR-71A & OD & 19.1 & 6.4 & 0.5 & 61.1 & 40.7 & 147.7 & 99.0 \\
\hline 8 & MR-27 & ID & 52.1 & 1.9 & 1.0 & 125.8 & 207.0 & 66.0 & 125.8 \\
\hline 9 & MR-5D & ID & 58.4 & 1.9 & 1.0 & 111.0 & 74.0 & 231.6 & 141.0 \\
\hline 10 & MR-5A & ID & 25.4 & 7.0 & 0.5 & 88.9 & 59.3 & 210.2 & 143.2 \\
\hline 11 & MR-5C & ID & 44.5 & 7.6 & 0.6 & 202.9 & 135.3 & 400.7 & 273.0 \\
\hline 12 & MR-5F & ID & 38.7 & 17.8 & 0.3 & 206.7 & 137.8 & 722.8 & 544.2 \\
\hline 13 & MR-8 & ID & 175.3 & 7.6 & 0.5 & 666.1 & 444.1 & $1,515.2$ & $1,066.1$ \\
\hline 14 & MR-5E & ID & 170.2 & 8.9 & 0.8 & $1,211.8$ & 807.9 & $1,801.3$ & $1,227.0$ \\
\hline 15 & MR-10 & ID & 13.3 & 241.3 & 0.8 & $2,567.4$ & $1,711.6$ & $3,616.7$ & $2,562.6$ \\
\hline
\end{tabular}

Table 2.21 Base Metal Defects in the Nozzles of the Hope Creek Unit 2 RPV

\begin{tabular}{||c|c|l|c|c||}
\hline \hline No. & NDE & Defect Type & Length (cm) & Repair ID \\
\hline 1 & (Mill referral) & Impressed scale and forging lap & (Not given) & MR-1A \\
\hline 2 & (Mill referral) & Impressed scale and forging lap & (Not given) & MR-1B \\
\hline
\end{tabular}

Table 2.22 Estimated Surface Area and Volume of Base Metal Repair in the Nozzles of the Hope Creek Unit 2 RPV

\begin{tabular}{|c|c|c|c|c|c|c|c|c|c|}
\hline \multirow[b]{2}{*}{ No. } & \multirow[b]{2}{*}{$\begin{array}{c}\text { Repair } \\
\text { ID }\end{array}$} & \multirow[b]{2}{*}{ ID/OD } & \multicolumn{3}{|c|}{ "Cavity Dimensions } & \multicolumn{2}{|c|}{ Volume } & \multicolumn{2}{|c|}{ " Surface Area } \\
\hline & & & $\begin{array}{c}\text { Length } \\
\text { (cm) }\end{array}$ & $\begin{array}{c}\text { Width } \\
\text { (cm) }\end{array}$ & $\begin{array}{c}\text { Depth } \\
\text { (cm) }\end{array}$ & $\begin{array}{c}\text { Bounding } \\
\left(\mathrm{cm}^{3}\right)\end{array}$ & \begin{tabular}{|c} 
Corrected \\
$\left(\mathrm{cm}^{3}\right)$
\end{tabular} & $\begin{array}{c}\text { Bounding } \\
\left(\mathrm{cm}^{2}\right)\end{array}$ & $\begin{array}{c}\text { Corrected } \\
\left(\mathrm{cm}^{2}\right)\end{array}$ \\
\hline 1 & MR-1A & OD & 7.6 & 1.3 & 1.0 & 9.9 & 6.6 & 27.7 & 15.9 \\
\hline 2 & MR-1B & OD & 17.8 & 3.2 & 2.5 & 142.4 & 94.9 & 162.0 & 92.7 \\
\hline
\end{tabular}

Table 2.23 Base Metal Defects in the Top Head of the River Bend Unit 2 RPV

\begin{tabular}{|c|c|c|c|c||}
\hline No. & NDE & Defect & Length (cm) & Repair \\
\hline 1 & MT & (Not given) & (Not given) & R-65 \\
\hline
\end{tabular}


Table 2.24 Estimated Surface Area and Volume of Base Metal Repair in the Top Head of the River Bend Unit 2 RPV

\begin{tabular}{|c|c|c|c|c|c|c|c|c|c|}
\hline \multirow[b]{2}{*}{ No. } & \multirow[b]{2}{*}{$\begin{array}{l}\text { Repair } \\
\text { ID }\end{array}$} & \multirow[b]{2}{*}{ ID/OD } & \multicolumn{3}{|c|}{ Cavity Dimensions } & \multicolumn{2}{|c|}{ Volume } & \multicolumn{2}{|c|}{ Surface Area } \\
\hline & & & $\begin{array}{c}\text { Length } \\
\text { (cm) }\end{array}$ & $\begin{array}{l}\text { Width } \\
\text { (cm) }\end{array}$ & $\begin{array}{c}\text { Depth } \\
\text { (cm) }\end{array}$ & $\begin{array}{c}\text { Bounding } \\
\left(\mathrm{cm}^{3}\right)\end{array}$ & $\begin{array}{c}\text { Corrected } \\
\left(\mathrm{cm}^{3}\right)\end{array}$ & $\begin{array}{c}\text { Bounding } \\
\left(\mathrm{cm}^{2}\right)\end{array}$ & $\begin{array}{c}\text { Corrected } \\
\left(\mathrm{cm}^{2}\right)\end{array}$ \\
\hline 1 & R-65 & ID & 5.1 & 0.6 & 0.5 & 1.5 & 1.0 & 8.8 & 5.1 \\
\hline
\end{tabular}

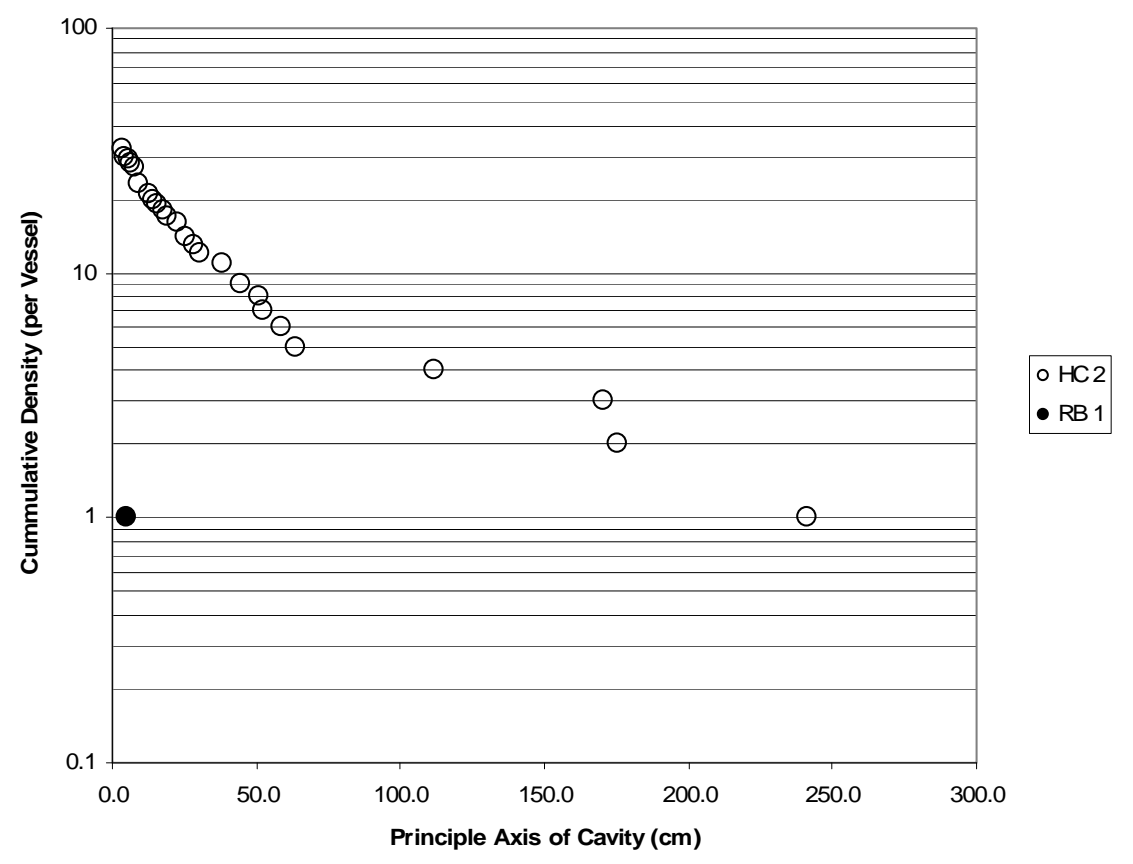

Figure 2.6 Comparison of Cavity Length in the Base Metal of Hope Creek Unit 2 and River Bend Unit 2 RPVs. Dimensions as described in the text.

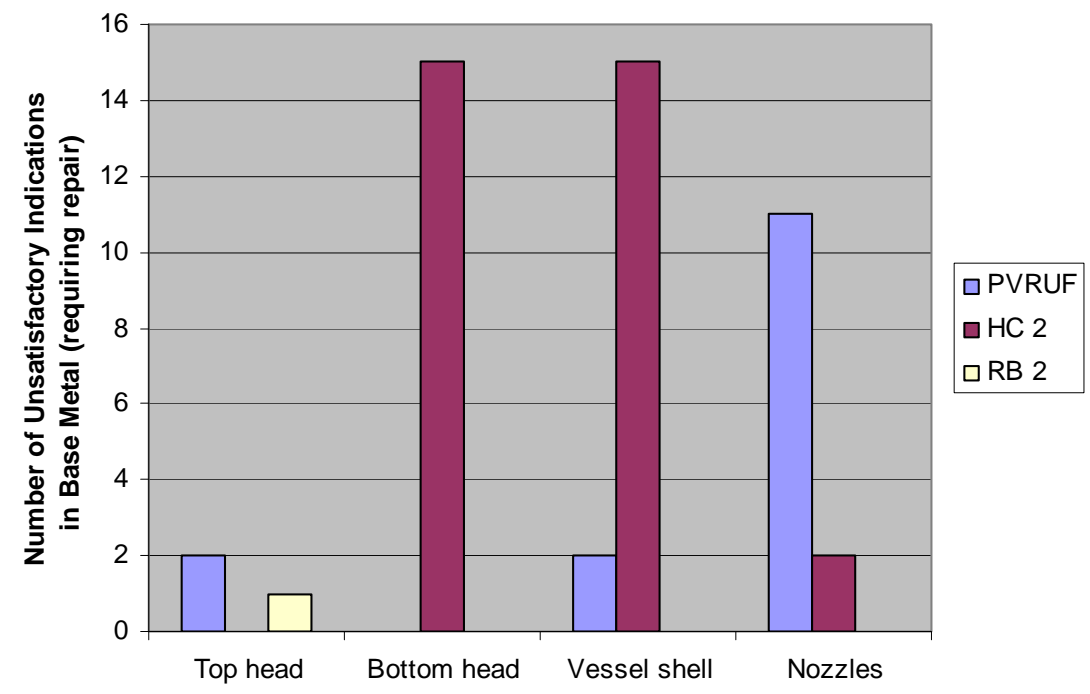

Figure 2.7 Comparison of Estimated Repair Frequency in the Base Metal of Three RPVs 


\subsection{RPV Material Handling Defects and Repairs}

Material handling defects were caused by attachment removal, intentional and accidental arc strikes, and other accidental gouging during fit-up and welding. The defects were shallow, less than $1.2 \mathrm{~cm}$ deep. Most of these were not found by NDE because most such gouges were visually apparent. Magnetic particle testing (MT) was performed, especially in the attachment removal areas.

In most cases, the construction records reported individual cavity dimensions for the repairs. It was reported that areas of the top head and shell of the Hope Creek Unit 2 RPV contained multiple repair cavities (more than eight in some areas), but the dimensions of only the largest cavity were recorded.

Table 2.25 provides an overview of the material handling repair information for the three RPVs. The information tables are listed in Table 2.25 for the separate subassemblies of the vessels. Material handling defects and repairs were caused mostly by temporary attachment removal.

The unsatisfactory inspection of material handling defects in the top head, bottom head, and shell of the PVRUF RPV are listed in Tables 2.26 through 2.28. Twelve unsatisfactory indications found in the magnetic particle testing were reported. No information on defect type was given for them. No data were entered into the chart of cavities records.

Table 2.29 lists the material handling defects reported in the bottom head of the Hope Creek Unit 2 RPV. Eight defects were reported on the surfaces of the bottom head. The construction records characterized six of the defects as temporary attachment removal and the other two as accidental welder arc strike or grinding error. The defects were not found by an NDE procedure but were visually apparent on the surfaces of the bottom head. Table 2.30 gives the estimated repair surface area and volume using the MR number from Table 2.29 to identify the defect. All of the defects were on the outside of the bottom head. All of the defects were shallow, with depths of less than $1 \mathrm{~cm}$.

Table 2.31 lists the material handling defects reported in the top head of the Hope Creek Unit 2 RPV. MR 109 reported seven defects on the surfaces of the top head. Repair MR-121 had a number of small defects, less than or equal to $2.5 \mathrm{~cm}$ in length, but the number of small defects was not reported. The construction records characterized the defects as temporary attachment removal. The defects were visually apparent on surfaces of the top head. Table 2.32 gives cavity dimensions where reported or the area that contained multiple repair cavities. All of the defects were shallow, with depths less than or equal to $1.2 \mathrm{~cm}$.

Table 2.33 lists the material handling defects reported in the shell of the Hope Creek Unit 2 RPV. MR 41, 110, 87, 40, 13, and 19 reported seven defects on the surfaces of the RPV shell. MR 19 A-J reported MT areas that contained approximately 56 repair cavities less than $10 \mathrm{~cm}$ long. MR 59 A-F and MR 7 A-F reported MT areas that contain numerous repair cavities of unreported length. The construction records characterized the defects as temporary attachment removal, except in three cases where they were characterized as arc strikes. An MT procedure was used in testing the repair of the temporary attachment removal areas. Table 2.34 gives the estimated surface area and volume. The cavity dimensions are given where reported, or the area that contained multiple repair cavities is given, if that is all that was reported. All of the defects were less than $1 \mathrm{~cm}$ deep. 
The four material handling defects reported on the surfaces of the nozzles of the Hope Creek Unit 2 RPV are listed in Table 2.35. The construction records characterized three of the defects as temporary attachment removal and the fourth as arc strike. The defects were visually apparent on the surfaces of the nozzles. Table 2.36 gives the estimated surface area and volume and then gives the nozzle type that contained the defect. All of the defects were shallow, with depths of less than $1 \mathrm{~cm}$.

Table 2.37 lists the two material handling defects reported on the surfaces of the bottom head from the River Bend Unit 2 RPV. The construction records characterized one of the defects as temporary attachment removal and the other as misplaced weld metal. The defects were visually apparent, requiring no NDE to find them. Table 2.38 gives the estimated repair surface area and volume and cavity dimension. All of the defects were shallow, less than $1 \mathrm{~cm}$ deep.

Table 2.39 lists the material handling defects reported in the top head of the River Bend Unit 2 RPV. Four defects were reported on the top head surfaces of the top head, all characterized by the construction records as temporary attachment removal gouges. The defects, visually apparent on the surfaces of the top head, were not found by an NDE procedure. Estimated repair surface area and volume and cavity dimension are shown in Table 2.40. All four defects were less than or equal to $1 \mathrm{~cm}$ in depth.

Table 2.41 lists the 18 material handling defects reported on the surfaces of the RPV shell from River Bend Unit 2. The construction records characterized 12 of the defects as temporary attachment removal, 5 as arc strikes, and 1 as a gouge on the seal surface of the flange. The defects were not found by an NDE procedure but instead were visually apparent on surfaces of the shell. Table 2.42 gives the estimated surface area and volume. The cavity dimensions are given for all repairs. All of the defects were less than $1 \mathrm{~cm}$ deep.

The single material handling defect reported in the nozzles of the River Bend Unit 2 RPV, described in Table 2.43, was characterized as a saw cut made by the nozzle vendor. The defect was visually apparent on the surface of a nozzle. Table 2.44 lists the estimated repair surface area and volume. The less than 1-cm-deep defect was repaired on the outside of a nozzle. Figure 2.8 compares the length distribution of material handling repairs in the Hope Creek Unit 2 and River Bend Unit 2 RPVs. Three data series-two for Hope Creek Unit 2 and one for River Bend Unit 2-are shown in Figure 2.8. The data series for the Hope Creek Unit 2 RPV shows the length of areas of multiple small repairs. What is known about these areas is discussed in the individual repair tables. For the River Bend Unit 2 RPV, the shell flange contained a 174-cm-long gouge on the seal surface. Figure 2.9 shows a comparison of estimated repair frequency for material handling defects in three vessels. The PVRUF RPV has the least such defects of the three vessels. More repairs were made to the shell of the vessels than to the other parts of the RPV.

\section{Table 2.25 Construction Record Contents for Material Handling Repairs in Three Reactor Pressure Vessels}

\begin{tabular}{||l|l|l|l||}
\hline & \multicolumn{1}{|c|}{ PVRUF } & \multicolumn{1}{|c|}{ Hope Creek Unit 2 } & \multicolumn{1}{c|}{ River Bend Unit 2 } \\
\hline Bottom head & Table 2.27 & Tables 2.29 and 2.30 & Tables 2.37 and 2.38 \\
\hline Top head & Table 2.26 & Tables 2.31 and 2.32 & Tables 2.39 and 2.40 \\
\hline Shell & Table 2.28 & Tables 2.33 and 2.34 & Tables 2.41 and 2.42 \\
\hline Nozzles & (None) & Tables 2.35 and 2.36 & Tables 2.43 and 2.44 \\
\hline
\end{tabular}


Table 2.26 Unsatisfactory Inspections (Requiring Repair) from Material Handling of the Top Head of the PVRUF RPV

\begin{tabular}{||c|c|c|c|c|c||}
\hline \hline No. & NDE & Defect Type & Length (cm) & Inspection ID & Job ID \\
\hline 1 & MT & (Not given) & (Not given) & A-117228 & $750101-001$ \\
\hline
\end{tabular}

Table 2.27 Unsatisfactory Inspections (Requiring Repair) from Material Handling of the Bottom Head of the PVRUF RPV

\begin{tabular}{|c|c|c|c|c|c|}
\hline \hline No. & NDE & Defect Type & $\begin{array}{c}\text { Length } \\
\text { (cm) }\end{array}$ & Inspection ID & Job ID \\
\hline 1 & MT & (Not given) & (Not given) & A-116200 & $750151-001$ \\
\hline
\end{tabular}

Table 2.28 Unsatisfactory Inspections (Requiring Repair) from Material Handling of the Shell of the PVRUF RPV

\begin{tabular}{|r|c|c|c|c|c||}
\hline No. & NDE & Defect Type & $\begin{array}{c}\text { Length } \\
\text { (cm) }\end{array}$ & $\begin{array}{c}\text { Inspection } \\
\text { ID }\end{array}$ & Job ID \\
\hline 1 & Visual & (Not given) & (Not given) & A-014508 & $750171-085$ \\
\hline 2 & MT & (Not given) & (Not given) & A-098099 & $750121-001$ \\
\hline 3 & MT & (Not given) & (Not given) & A-094371 & $750121-035$ \\
\hline 4 & MT & (Not given) & (Not given) & A-104234 & $750121-030$ \\
\hline 5 & MT & (Not given) & (Not given) & A-111603 & $750121-040$ \\
\hline 6 & MT & (Not given) & (Not given) & A-111719 & $750121-025$ \\
\hline 7 & MT & (Not given) & (Not given) & A-103312 & $750121-060$ \\
\hline 8 & MT & (Not given) & (Not given) & A-103331 & $750121-065$ \\
\hline 9 & MT & (Not given) & (Not given) & A-107903 & $750121-070$ \\
\hline 10 & MT & (Not given) & (Not given) & A-107943 & $750121-075$ \\
\hline
\end{tabular}

Table 2.29 Material Handling Defects in the Bottom Head of the Hope Creek Unit 2 RPV

\begin{tabular}{||c|c|l|c|c||}
\hline \hline No. & NDE & \multicolumn{1}{|c|}{$\begin{array}{c}\text { Defect } \\
\text { Type }\end{array}$} & $\begin{array}{c}\text { Length } \\
\text { (cm) }\end{array}$ & Repair ID \\
\hline 1 & (Visual) & Lug removal & (Not given) & MR-78C \\
\hline 2 & (Visual) & Lug removal & (Not given) & MR-78B \\
\hline 3 & (Visual) & Auto welder arc strike & (Not given) & MR-76B \\
\hline 4 & (Visual) & Ground out low spot & (Not given) & MR-76A \\
\hline 5 & (Visual) & Lug removal & (Not given) & MR-78A \\
\hline 6 & (Visual) & Lug removal & (Not given) & MR101A \\
\hline 7 & (Visual) & Lug removal & (Not given) & MR101B \\
\hline 8 & (Visual) & Lug removal & (Not given) & MR101C \\
\hline
\end{tabular}


Table 2.30 Estimated Surface Area and Volume of Material Handling Repair in the Bottom Head of the Hope Creek Unit 2 RPV

\begin{tabular}{|c|c|c|c|c|c|c|c|c|c|}
\hline \multirow[b]{2}{*}{ No. } & \multirow[b]{2}{*}{$\begin{array}{l}\text { Repair } \\
\text { ID }\end{array}$} & \multirow[b]{2}{*}{ ID/OD } & \multicolumn{3}{|c|}{ Cavity Dimensions } & \multicolumn{2}{|c|}{ Volume } & \multicolumn{2}{|c|}{ Surface Area } \\
\hline & & & $\begin{array}{c}\text { Length } \\
\text { (cm) }\end{array}$ & $\begin{array}{c}\text { Width } \\
\text { (cm) }\end{array}$ & $\begin{array}{c}\text { Depth } \\
\text { (cm) }\end{array}$ & $\begin{array}{c}\text { Bounding } \\
\left(\mathrm{cm}^{3}\right)\end{array}$ & \begin{tabular}{|c|} 
Corrected \\
$\left(\mathrm{cm}^{3}\right)$
\end{tabular} & $\begin{array}{c}\text { Bounding } \\
\left(\mathrm{cm}^{2}\right)\end{array}$ & $\begin{array}{c}\text { Corrected } \\
\left(\mathrm{cm}^{2}\right)\end{array}$ \\
\hline 1 & MR-78C & OD & 3.8 & 1.9 & 0.2 & 1.4 & 1.0 & 9.5 & 6.0 \\
\hline 2 & MR-78B & OD & 3.2 & 3.2 & 0.2 & 2.0 & 1.4 & 12.8 & 8.3 \\
\hline 3 & MR-76B & OD & 5.1 & 2.5 & 0.6 & 7.7 & 5.1 & 21.9 & 12.4 \\
\hline 4 & MR-76A & OD & 6.4 & 2.4 & 0.6 & 9.2 & 6.1 & 25.9 & 14.9 \\
\hline 5 & MR-78A & OD & 8.9 & 6.4 & 0.2 & 11.4 & 7.6 & 63.1 & 45.2 \\
\hline 6 & MR101A & OD & 8.9 & 6.4 & 0.2 & 11.4 & 7.6 & 63.1 & 45.2 \\
\hline 7 & MR101B & OD & 3.2 & 3.2 & 0.2 & 2.0 & 1.4 & 12.8 & 8.3 \\
\hline 8 & MR101C & OD & 3.8 & 1.9 & 0.2 & 1.4 & 1.0 & 9.5 & 6.0 \\
\hline
\end{tabular}

Table 2.31 Material Handling Defects in the Top Head of the Hope Creek Unit 2 RPV

\begin{tabular}{||c|c|c|c|c||}
\hline \hline NDE & $\begin{array}{c}\text { Defect } \\
\text { Type }\end{array}$ & $\begin{array}{c}\text { Length } \\
\text { (cm) }\end{array}$ & Repair ID \\
\hline 1 & (Visual) & Attachment removal & (Not given) & MR-109A \\
\hline 2 & (Visual) & Attachment removal & (Not given) & MR-109B \\
\hline 3 & (Visual) & Attachment removal & (Not given) & MR-109C \\
\hline 4 & (Visual) & Attachment removal & (Not given) & MR-109D \\
\hline 5 & (Visual) & Attachment removal & (Not given) & MR-109G \\
\hline 6 & (Visual) & Attachment removal & (Not given) & MR-109H \\
\hline 7 & (Visual) & Attachment removal & (Not given) & MR-109J \\
\hline 8 & (Visual) & Attachment removal & (Not given) & MR-121 \\
\hline
\end{tabular}

Table 2.32 Estimated Surface Area and Volume of Material Handling Repair in the Top Head of the Hope Creek Unit 2 RPV

\begin{tabular}{|c|c|c|c|c|c|c|c|c|c|}
\hline \multirow[b]{2}{*}{ No. } & \multirow[b]{2}{*}{$\begin{array}{l}\text { Repair } \\
\text { ID }\end{array}$} & \multirow[b]{2}{*}{ ID/OD } & \multicolumn{3}{|c|}{ Cavity Dimensions } & \multicolumn{2}{|c|}{ Volume } & \multicolumn{2}{|c|}{ Surface Area } \\
\hline & & & $\begin{array}{c}\text { Length } \\
\text { (cm) }\end{array}$ & $\begin{array}{l}\text { Width } \\
\text { (cm) }\end{array}$ & $\begin{array}{c}\text { Depth } \\
\text { (cm) }\end{array}$ & $\begin{array}{c}\text { Bounding } \\
\left(\mathrm{cm}^{3}\right)\end{array}$ & \begin{tabular}{|c|} 
Corrected \\
$\left(\mathrm{cm}^{3}\right)$
\end{tabular} & $\begin{array}{c}\text { Bounding } \\
\left(\mathrm{cm}^{2}\right)\end{array}$ & \begin{tabular}{|c} 
Corrected \\
$\left(\mathrm{cm}^{2}\right)$
\end{tabular} \\
\hline 1 & MR-109A & (n.g.) & 5.1 & 1.6 & 0.3 & 2.4 & 1.6 & 12.2 & 7.3 \\
\hline 2 & MR-109B & (n.g.) & 5.1 & 0.6 & 0.2 & 0.6 & 0.4 & 5.3 & 3.2 \\
\hline 3 & MR-109C & (n.g.) & 12.7 & 1.9 & 0.2 & 4.8 & 3.2 & 30.0 & 19.8 \\
\hline 4 & MR-109D & (n.g.) & 2.5 & 1.0 & 0.3 & 0.8 & 0.5 & 4.6 & 2.6 \\
\hline 5 & MR-109G & (n.g.) & 12.7 & 1.3 & 0.3 & 5.0 & 3.3 & 24.9 & 15.2 \\
\hline 6 & MR-109H & (n.g.) & 3.8 & 0.6 & 0.3 & 0.7 & 0.5 & 4.9 & 2.8 \\
\hline 7 & MR-109J & (n.g.) & 20.3 & 1.0 & 0.2 & 4.1 & 2.7 & 28.8 & 18.0 \\
\hline$\ldots$ & MR-121 & (n.g.) & 193.5 & 2.4 & 1.2 & 557.3 & 371.5 & 934.6 & 573.0 \\
\hline
\end{tabular}


Table 2.33 Material Handling Defects in the Shell of the Hope Creek Unit 2 RPV

\begin{tabular}{||c|c|c|c|c||}
\hline \hline & NDE & $\begin{array}{c}\text { Defect } \\
\text { Type }\end{array}$ & $\begin{array}{c}\text { Length } \\
\text { (cm) }\end{array}$ & Repair ID \\
\hline 1 & (Not given) & Attachment removal & (Not given) & MR-41 \\
\hline 2 & (Not given) & Attachment removal & (Not given) & MR-110 \\
\hline 3 & (Not given) & Attachment removal & (Not given) & MR-87 \\
\hline 4 & (Not given) & Attachment removal & (Not given) & MR-40 \\
\hline 5 & (Not given) & Attachment removal & (Not given) & MR-13A \\
\hline 6 & (Not given) & Attachment removal & (Not given) & MR-13B \\
\hline 7 & (Not given) & Attachment removal & (Not given) & MR-19 \\
\hline 8 & (Not given) & Attachment removal & (Not given) & MR-19A \\
\hline 9 & (Not given) & Attachment removal & (Not given) & MR-19B \\
\hline 10 & (Not given) & Attachment removal & (Not given) & MR-19C \\
\hline 11 & (Not given) & Attachment removal & (Not given) & MR-19E \\
\hline 12 & (Not given) & Attachment removal & (Not given) & MR-19F \\
\hline 13 & (Not given) & Attachment removal & (Not given) & MR-19G \\
\hline 14 & (Not given) & Attachment removal & (Not given) & MR-19H \\
\hline 15 & (Not given) & Attachment removal & (Not given) & MR-19I \\
\hline 16 & (Not given) & Attachment removal & (Not given) & MR-19J \\
\hline 17 & (Not given) & Attachment removal & (Not given) & MR-59A \\
\hline 18 & (Not given) & Attachment removal & (Not given) & MR-59B \\
\hline 19 & (Not given) & Attachment removal & (Not given) & MR-59C \\
\hline 20 & (Not given) & Attachment removal & (Not given) & MR-59D \\
\hline 21 & (Not given) & Attachment removal & (Not given) & MR-59E \\
\hline 22 & (Not given) & Attachment removal & (Not given) & MR-59F \\
\hline 23 & (Not given) & Attachment removal & (Not given) & MR-7A \\
\hline 24 & (Not given) & Attachment removal & (Not given) & MR-7B \\
\hline 25 & (Not given) & Attachment removal & (Not given) & MR-7C \\
\hline 26 & (Not given) & Attachment removal & (Not given) & MR-7D \\
\hline 27 & (Not given) & Attachment removal & (Not given) & MR-7E \\
\hline 28 & (Not given) & Attachment removal & (Not given) & MR-7F \\
\hline
\end{tabular}


Table 2.34 Estimated Surface Area and Volume of Material Handling Repair in the Shell of the Hope Creek Unit 2 RPV

\begin{tabular}{|c|c|c|c|c|c|c|c|c|c|}
\hline \multirow[b]{2}{*}{ No. } & \multirow[b]{2}{*}{$\begin{array}{l}\text { Repair } \\
\text { ID }\end{array}$} & \multirow[b]{2}{*}{ ID/OD } & \multicolumn{3}{|c|}{ "Cavity Dimensions } & \multicolumn{2}{|c|}{ Volume } & \multicolumn{2}{|c|}{ Surface Area } \\
\hline & & & $\begin{array}{c}\text { Length } \\
\text { (cm) }\end{array}$ & $\begin{array}{c}\text { Width } \\
\text { (cm) }\end{array}$ & $\begin{array}{c}\text { Depth } \\
\text { (cm) }\end{array}$ & $\begin{array}{c}\text { Bounding } \\
\left(\mathrm{cm}^{3}\right)\end{array}$ & \begin{tabular}{|c|} 
Corrected \\
$\left(\mathrm{cm}^{3}\right)$
\end{tabular} & $\begin{array}{c}\text { Bounding } \\
\left(\mathrm{cm}^{2}\right)\end{array}$ & $\begin{array}{c}\text { Corrected } \\
\left(\mathrm{cm}^{2}\right)\end{array}$ \\
\hline 1 & MR-41 & OD & 2.5 & 0.6 & 0.3 & 0.5 & 0.3 & 3.4 & 1.9 \\
\hline 2 & MR-110 & OD & 3.8 & 1.6 & 0.3 & 1.8 & 1.2 & 9.3 & 5.5 \\
\hline 3 & MR-87 & OD & 5.7 & 1.3 & 0.6 & 4.4 & 3.0 & 15.8 & 9.0 \\
\hline 4 & MR-40 & ID & 10.2 & 1.3 & 0.4 & 5.3 & 3.5 & 22.5 & 13.4 \\
\hline 5 & MR-13A & OD & 2.5 & 6.4 & 0.8 & 12.8 & 8.5 & 30.2 & 17.0 \\
\hline 6 & MR-13B & OD & 3.8 & 6.4 & 0.5 & 12.2 & 8.1 & 34.5 & 20.9 \\
\hline 7 & MR-19 & OD & 10.2 & 5.1 & 0.4 & 20.8 & 13.9 & 64.3 & 42.3 \\
\hline 8 & MR-19A & OD & 73.7 & 3.8 & 0.4 & 112.0 & 74.7 & 342.1 & 229.0 \\
\hline 9 & MR-19B & OD & 73.7 & 3.8 & 0.4 & 112.0 & 74.7 & 342.1 & 229.0 \\
\hline 10 & MR-19C & OD & 73.7 & 3.8 & 0.4 & 112.0 & 74.7 & 342.1 & 229.0 \\
\hline 11 & MR-19E & OD & 73.7 & 3.8 & 0.4 & 112.0 & 74.7 & 342.1 & 229.0 \\
\hline 12 & MR-19F & OD & 73.7 & 3.8 & 0.4 & 112.0 & 74.7 & 342.1 & 229.0 \\
\hline 13 & MR-19G & OD & 73.7 & 3.8 & 0.4 & 112.0 & 74.7 & 342.1 & 229.0 \\
\hline 14 & MR-19H & OD & 73.7 & 3.8 & 0.4 & 112.0 & 74.7 & 342.1 & 229.0 \\
\hline 15 & MR-19I & OD & 73.7 & 3.8 & 0.4 & 112.0 & 74.7 & 342.1 & 229.0 \\
\hline 16 & MR-19J & OD & 73.7 & 3.8 & 0.4 & 112.0 & 74.7 & 342.1 & 229.0 \\
\hline 17 & MR-59A & OD & 76.2 & 5.1 & 0.3 & 116.6 & 77.7 & 437.4 & 310.2 \\
\hline 18 & MR-59B & OD & 76.2 & 5.1 & 0.3 & 116.6 & 77.7 & 437.4 & 310.2 \\
\hline 19 & MR-59C & OD & 76.2 & 5.1 & 0.3 & 116.6 & 77.7 & 437.4 & 310.2 \\
\hline 20 & MR-59D & OD & 76.2 & 5.1 & 0.3 & 116.6 & 77.7 & 437.4 & 310.2 \\
\hline 21 & MR-59E & OD & 76.2 & 5.1 & 0.3 & 116.6 & 77.7 & 437.4 & 310.2 \\
\hline 22 & MR-59F & OD & 76.2 & 5.1 & 0.3 & 116.6 & 77.7 & 437.4 & 310.2 \\
\hline 23 & MR-7A & OD & 91.4 & 30.5 & 0.5 & $1,393.9$ & 929.2 & $2,909.6$ & $2,201.7$ \\
\hline 24 & MR-7B & OD & 91.4 & 30.5 & 0.5 & $1,393.9$ & 929.2 & $2,909.6$ & $2,201.7$ \\
\hline 25 & MR-7C & OD & 91.4 & 30.5 & 0.5 & $1,393.9$ & 929.2 & $2,909.6$ & $2,201.7$ \\
\hline 26 & MR-7D & OD & 91.4 & 30.5 & 0.5 & $1,393.9$ & 929.2 & $2,909.6$ & $2,201.7$ \\
\hline 27 & MR-7E & OD & 91.4 & 30.5 & 0.5 & $1,393.9$ & 929.2 & $2,909.6$ & $2,201.7$ \\
\hline 28 & MR-7F & OD & 91.4 & 30.5 & 0.5 & $1,393.9$ & 929.2 & $2,909.6$ & $2,201.7$ \\
\hline
\end{tabular}

Table 2.35 Material Handling Defects in the Nozzles of the Hope Creek Unit 2 RPV

\begin{tabular}{|c|c|l|c|c||}
\hline \hline & NDE & \multicolumn{1}{|c|}{$\begin{array}{c}\text { Defect } \\
\text { Type }\end{array}$} & $\begin{array}{c}\text { Length } \\
\text { (cm) }\end{array}$ & Repair ID \\
\hline 1 & (Visual) & Gouge - fit-up lug removed & (Not given) & MR-68 \\
\hline 2 & (Visual) & Arc strike & (Not given) & MR-70 \\
\hline 3 & (Visual) & Remove nozzle heater lug & (Not given) & MR-56 \\
\hline 4 & (Visual) & Remove temp attachments & (Not given) & MR-95 \\
\hline \hline
\end{tabular}


Table 2.36 Estimated Surface Area and Volume of Material Handling Repair in the Nozzles of the Hope Creek Unit 2 RPV

\begin{tabular}{|c|c|c|c|c|c|c|c|c|c|}
\hline \multirow[b]{2}{*}{ No. } & \multirow[b]{2}{*}{$\begin{array}{c}\text { Repair } \\
\text { ID }\end{array}$} & \multirow[b]{2}{*}{ ID/OD } & \multicolumn{3}{|c|}{ Cavity Dimensions } & \multicolumn{2}{|c|}{ Volume } & \multicolumn{2}{|c|}{ Surface Area } \\
\hline & & & $\begin{array}{c}\text { Length } \\
\text { (cm) }\end{array}$ & $\begin{array}{l}\text { Width } \\
\text { (cm) }\end{array}$ & $\begin{array}{c}\text { Depth } \\
\text { (cm) }\end{array}$ & $\begin{array}{c}\text { Bounding } \\
\left(\mathrm{cm}^{3}\right)\end{array}$ & \begin{tabular}{|c|} 
Corrected \\
$\left(\mathrm{cm}^{3}\right)$
\end{tabular} & $\begin{array}{c}\text { Bounding } \\
\left(\mathrm{cm}^{2}\right)\end{array}$ & $\begin{array}{c}\text { Corrected } \\
\left(\mathrm{cm}^{2}\right)\end{array}$ \\
\hline 1 & MR-68 & ID & 7.6 & 1.6 & 0.3 & 3.6 & 2.4 & 17.7 & 10.8 \\
\hline 2 & MR-70 & OD & 5.1 & 2.5 & 0.6 & 7.7 & 5.1 & 21.9 & 12.4 \\
\hline 3 & MR-56 & ID & 12.7 & 1.3 & 0.4 & 6.6 & 4.4 & 27.7 & 16.6 \\
\hline 4 & MR-95 & ID & 15.2 & 15.2 & 0.5 & 115.5 & 77.0 & 261.4 & 184.0 \\
\hline
\end{tabular}

Table 2.37 Material Handling Defects in the Bottom Head of the River Bend Unit 2 RPV

\begin{tabular}{||c|c|l|c|c||}
\hline \hline & NDE & \multicolumn{1}{|c|}{$\begin{array}{c}\text { Defect } \\
\text { Type }\end{array}$} & $\begin{array}{c}\text { Length } \\
(\mathbf{c m})\end{array}$ & Repair ID \\
\hline 1 & (Visual) & Gouges at strong-back removal areas & (Not given) & MR-3 \\
\hline 2 & (Visual) & Misplaced 7018 weld metal & (Not given) & MR-2 \\
\hline
\end{tabular}

Table 2.38 Estimated Surface Area and Volume of Material Handling Repair in the Bottom Head of the River Bend Unit 2 RPV

\begin{tabular}{|c|c|c|c|c|c|c|c|c|c|}
\hline \multirow[b]{2}{*}{ No. } & \multirow[b]{2}{*}{$\begin{array}{l}\text { Repair } \\
\text { ID }\end{array}$} & \multirow[b]{2}{*}{ ID/OD } & \multicolumn{3}{|c|}{ "Cavity Dimensions } & \multicolumn{2}{|c|}{ Volume } & \multicolumn{2}{|c|}{ " Surface Area } \\
\hline & & & $\begin{array}{c}\text { Length } \\
\text { (cm) }\end{array}$ & $\begin{array}{c}\text { Width } \\
\text { (cm) }\end{array}$ & $\begin{array}{c}\text { Depth } \\
\text { (cm) }\end{array}$ & $\begin{array}{c}\text { Bounding } \\
\left(\mathrm{cm}^{3}\right)\end{array}$ & $\begin{array}{c}\text { Corrected } \\
\left(\mathrm{cm}^{3}\right)\end{array}$ & $\begin{array}{c}\text { Bounding } \\
\left(\mathbf{c m}^{2}\right)\end{array}$ & $\begin{array}{c}\text { Corrected } \\
\left(\mathrm{cm}^{2}\right)\end{array}$ \\
\hline 1 & $\mathrm{R}-3$ & ID & 6.4 & 1.0 & 0.6 & 3.8 & 2.6 & 15.3 & 8.8 \\
\hline 2 & R-2 & OD & 5.1 & 1.9 & 0.6 & 5.8 & 3.9 & 18.1 & 10.2 \\
\hline
\end{tabular}

Table 2.39 Material Handling Defects in the Top Head of the River Bend Unit 2 RPV

\begin{tabular}{||c|c|c|c|c||}
\hline & NDE & $\begin{array}{c}\text { Defect } \\
\text { Type }\end{array}$ & $\begin{array}{c}\text { Length } \\
\text { (cm) }\end{array}$ & Repair ID \\
\hline 1 & (Visual) & Gouges at fit-up gear removal areas & (Not given) & R-66A \\
\hline 2 & (Visual) & Gouges at fit-up gear removal areas & (Not given) & R-66B \\
\hline 3 & (Visual) & Gouges at fit-up gear removal areas & (Not given) & R-66C \\
\hline 4 & (Visual) & Gouges at fit-up gear removal areas & (Not given) & R-66E \\
\hline 5 & (Visual) & Gouges at fit-up gear removal areas & (Not given) & R-66F \\
\hline
\end{tabular}


Table 2.40 Estimated Surface Area and Volume of Material Handling Repair in the Top Head of the River Bend Unit 2 RPV

\begin{tabular}{|c|c|c|c|c|c|c|c|c|c|}
\hline \multirow[b]{2}{*}{ No. } & \multirow[b]{2}{*}{$\begin{array}{l}\text { Repair } \\
\text { ID }\end{array}$} & \multirow[b]{2}{*}{ ID/OD } & \multicolumn{3}{|c|}{ Cavity Dimensions } & \multicolumn{2}{|c|}{ Volume } & \multicolumn{2}{|c|}{ Surface Area } \\
\hline & & & $\begin{array}{c}\text { Length } \\
\text { (cm) }\end{array}$ & $\begin{array}{c}\text { Width } \\
\text { (cm) }\end{array}$ & $\begin{array}{c}\text { Depth } \\
\text { (cm) }\end{array}$ & $\begin{array}{c}\text { Bounding } \\
\left(\mathrm{cm}^{3}\right)\end{array}$ & $\begin{array}{c}\text { Corrected } \\
\left(\mathrm{cm}^{3}\right)\end{array}$ & $\begin{array}{c}\text { Bounding } \\
\left(\mathrm{cm}^{2}\right)\end{array}$ & $\begin{array}{c}\text { Corrected } \\
\left(\mathrm{cm}^{2}\right)\end{array}$ \\
\hline 1 & R-66A & ID & 2.5 & 0.6 & 0.2 & 0.3 & 0.2 & 2.7 & 1.6 \\
\hline 2 & R-66B & ID & 4.4 & 0.6 & 0.2 & 0.5 & 0.4 & 4.6 & 2.7 \\
\hline 3 & R-66C & ID & 1.9 & 0.6 & 0.2 & 0.2 & 0.2 & 2.1 & 1.2 \\
\hline 4 & R-66E & ID & 6.4 & 0.6 & 1.0 & 3.8 & 2.6 & $\begin{array}{ll}17.8 \\
\end{array}$ & 11.0 \\
\hline 5 & R-66F & ID & 4.4 & 0.6 & 0.2 & 0.5 & 0.4 & 4.6 & 2.7 \\
\hline
\end{tabular}

Table 2.41 Material Handling Defects in the Shell of the River Bend Unit 2 RPV

\begin{tabular}{|c|c|c|c|c|}
\hline & NDE & $\begin{array}{c}\text { Defect } \\
\text { Type }\end{array}$ & Length (cm) & Repair ID \\
\hline 1 & (Visual) & Temp attachment removal & (Not given) & $\mathrm{R}-4 \mathrm{~B}$ \\
\hline 2 & (Visual) & Arc gouge & (Not given) & $\mathrm{R}-32 \mathrm{~A}$ \\
\hline 3 & (Visual) & Arc strike & (Not given) & $\mathrm{R}-18$ \\
\hline 4 & (Visual) & Temp attachment removal & (Not given) & $\mathrm{R}-4 \mathrm{~A}$ \\
\hline 5 & (Visual) & Arc gouge & (Not given) & $\mathrm{R}-40$ \\
\hline 6 & (Visual) & Temp attachment removal & (Not given) & $\mathrm{R}-4 \mathrm{C}$ \\
\hline 7 & (Visual) & Arc gouge & (Not given) & $\mathrm{R}-32 \mathrm{~B}$ \\
\hline 8 & (Visual) & Temp attachment removal & (Not given) & $\mathrm{R}-28 \mathrm{~A}$ \\
\hline 9 & (Visual) & Temp attachment removal & (Not given) & $\mathrm{R}-25$ \\
\hline 10 & (Visual) & Temp attachment removal & (Not given) & $\mathrm{R}-28 \mathrm{~B}$ \\
\hline 11 & (Visual) & Temp attachment removal & (Not given) & $\mathrm{R}-8 \mathrm{~B}$ \\
\hline 12 & (Visual) & Temp attachment removal & (Not given) & $\mathrm{R}-28 \mathrm{C}$ \\
\hline 13 & (Visual) & Temp attachment removal & (Not given) & $\mathrm{R}-8 \mathrm{~A}$ \\
\hline 14 & (Visual) & Arc strike & (Not given) & $\mathrm{R}-24$ \\
\hline 15 & (Visual) & Temp attachment removal & (Not given) & $\mathrm{R}-5 \mathrm{C}$ \\
\hline 16 & (Visual) & Temp attachment removal & (Not given) & R-5A \\
\hline 17 & (Visual) & Temp attachment removal & (Not given) & $\mathrm{R}-5 \mathrm{~B}$ \\
\hline 18 & (Visual) & Gouge on seal surface & (Not given) & $\mathrm{R}-52$ \\
\hline
\end{tabular}


Table 2.42 Estimated Surface Area and Volume of Material Handling Repair in the Shell of the River Bend Unit 2 RPV

\begin{tabular}{|c|c|c|c|c|c|c|c|c|c|}
\hline \multirow[b]{2}{*}{ No. } & \multirow[b]{2}{*}{$\begin{array}{c}\text { Repair } \\
\text { ID }\end{array}$} & \multirow[b]{2}{*}{ ID/OD } & \multicolumn{3}{|c|}{ Cavity Dimensions } & \multicolumn{2}{|c|}{ Volume } & \multicolumn{2}{|c|}{ Surface Area } \\
\hline & & & $\begin{array}{c}\text { Length } \\
\text { (cm) }\end{array}$ & $\begin{array}{c}\text { Width } \\
\text { (cm) }\end{array}$ & $\begin{array}{c}\text { Depth } \\
\text { (cm) }\end{array}$ & $\begin{array}{c}\text { Bounding } \\
\left(\mathrm{cm}^{3}\right)\end{array}$ & $\begin{array}{c}\text { Corrected } \\
\left(\mathrm{cm}^{3}\right)\end{array}$ & $\begin{array}{c}\text { Bounding } \\
\left(\mathrm{cm}^{2}\right)\end{array}$ & $\begin{array}{c}\text { Corrected } \\
\left(\mathrm{cm}^{2}\right)\end{array}$ \\
\hline 1 & $\mathrm{R}-4 \mathrm{~B}$ & OD & 1.3 & 0.6 & 0.3 & 0.2 & 0.2 & 1.9 & 1.0 \\
\hline 2 & R-32A & OD & 2.5 & 0.6 & 0.4 & 0.6 & 0.4 & 4.0 & 2.2 \\
\hline 3 & R-18 & OD & 3.2 & 0.8 & 0.2 & 0.5 & 0.3 & 4.2 & 2.4 \\
\hline 4 & $\mathrm{R}-4 \mathrm{~A}$ & OD & 4.4 & 0.6 & 0.2 & 0.5 & 0.4 & 4.6 & 2.7 \\
\hline 5 & R-40 & OD & 3.8 & 0.6 & 0.3 & 0.7 & 0.5 & 4.9 & 2.8 \\
\hline 6 & R-4C & OD & 3.2 & 1.3 & 0.3 & 1.2 & 0.8 & 6.9 & 4.0 \\
\hline 7 & R-32B & OD & 3.5 & 1.3 & 0.5 & 2.3 & 1.5 & 9.4 & 5.2 \\
\hline 8 & R-28A & OD & 10.2 & 0.6 & 0.3 & 1.8 & 1.2 & 12.6 & 7.6 \\
\hline 9 & R-25 & OD & 10.2 & 0.6 & 0.4 & 2.4 & 1.6 & 14.8 & 8.9 \\
\hline 10 & $\mathrm{R}-28 \mathrm{~B}$ & OD & 7.6 & 1.3 & 0.5 & 4.9 & 3.3 & 18.8 & 10.9 \\
\hline 11 & $\mathrm{R}-8 \mathrm{~B}$ & OD & 10.8 & 0.6 & 0.5 & 3.2 & 2.2 & 17.9 & 10.8 \\
\hline 12 & $\mathrm{R}-28 \mathrm{C}$ & OD & 11.4 & 1.6 & 0.5 & 9.1 & 6.1 & 31.2 & 18.5 \\
\hline 13 & R-8A & OD & 15.2 & 1.6 & 0.5 & 12.2 & 8.1 & 41.1 & 24.6 \\
\hline 14 & R-24 & ID & 8.6 & 3.8 & 0.3 & 9.8 & 6.5 & 40.1 & 26.6 \\
\hline 15 & R-5C & OD & 27.9 & 1.9 & 0.6 & 31.8 & 21.2 & 88.8 & 53.8 \\
\hline 16 & R-5A & OD & 25.4 & 2.2 & 0.8 & 44.7 & 29.8 & 100.0 & 60.0 \\
\hline 17 & R-5B & OD & 36.8 & 1.9 & 0.6 & 42.0 & 28.0 & 116.4 & 70.8 \\
\hline 18 & R-52 & OD & 172.7 & 1.0 & 0.2 & 34.5 & 23.0 & 242.2 & 152.9 \\
\hline
\end{tabular}

Table 2.43 Material Handling Defects in the Nozzles of the River Bend Unit 2 RPV

\begin{tabular}{|c|c|c|c|c|}
\hline No. & NDE & Defect Type & Length (cm) & Repair ID \\
\hline 1 & (Visual) & Saw cut by vendor & (Not given) & R-6 \\
\hline
\end{tabular}

Table 2.44 Estimated Surface Area and Volume of Material Handling Repair in the Nozzles of the River Bend Unit 2 RPV

\begin{tabular}{|c|c|c|c|c|c|c|c|c|c|}
\hline \multirow[b]{2}{*}{ No. } & \multirow[b]{2}{*}{$\begin{array}{l}\text { Repair } \\
\text { ID }\end{array}$} & \multirow[b]{2}{*}{ ID/OD } & \multicolumn{3}{|c|}{ Cavity Dimensions } & \multicolumn{2}{|c|}{ Volume } & \multicolumn{2}{|c|}{ Surface Area } \\
\hline & & & $\begin{array}{l}\text { Length } \\
\text { (cm) }\end{array}$ & $\begin{array}{c}\text { Width } \\
\text { (cm) }\end{array}$ & $\begin{array}{c}\text { Depth } \\
\text { (cm) }\end{array}$ & $\begin{array}{c}\text { Bounding } \\
\left(\mathrm{cm}^{3}\right)\end{array}$ & $\begin{array}{c}\text { Corrected } \\
\left(\mathrm{cm}^{3}\right)\end{array}$ & $\begin{array}{c}\text { Bounding } \\
\left(\mathrm{cm}^{2}\right)\end{array}$ & $\begin{array}{c}\text { Corrected } \\
\left(\mathrm{cm}^{2}\right)\end{array}$ \\
\hline 1 & R-6 & OD & 15.2 & 1.3 & 0.6 & 11.9 & 7.9 & 39.6 & 23.6 \\
\hline
\end{tabular}




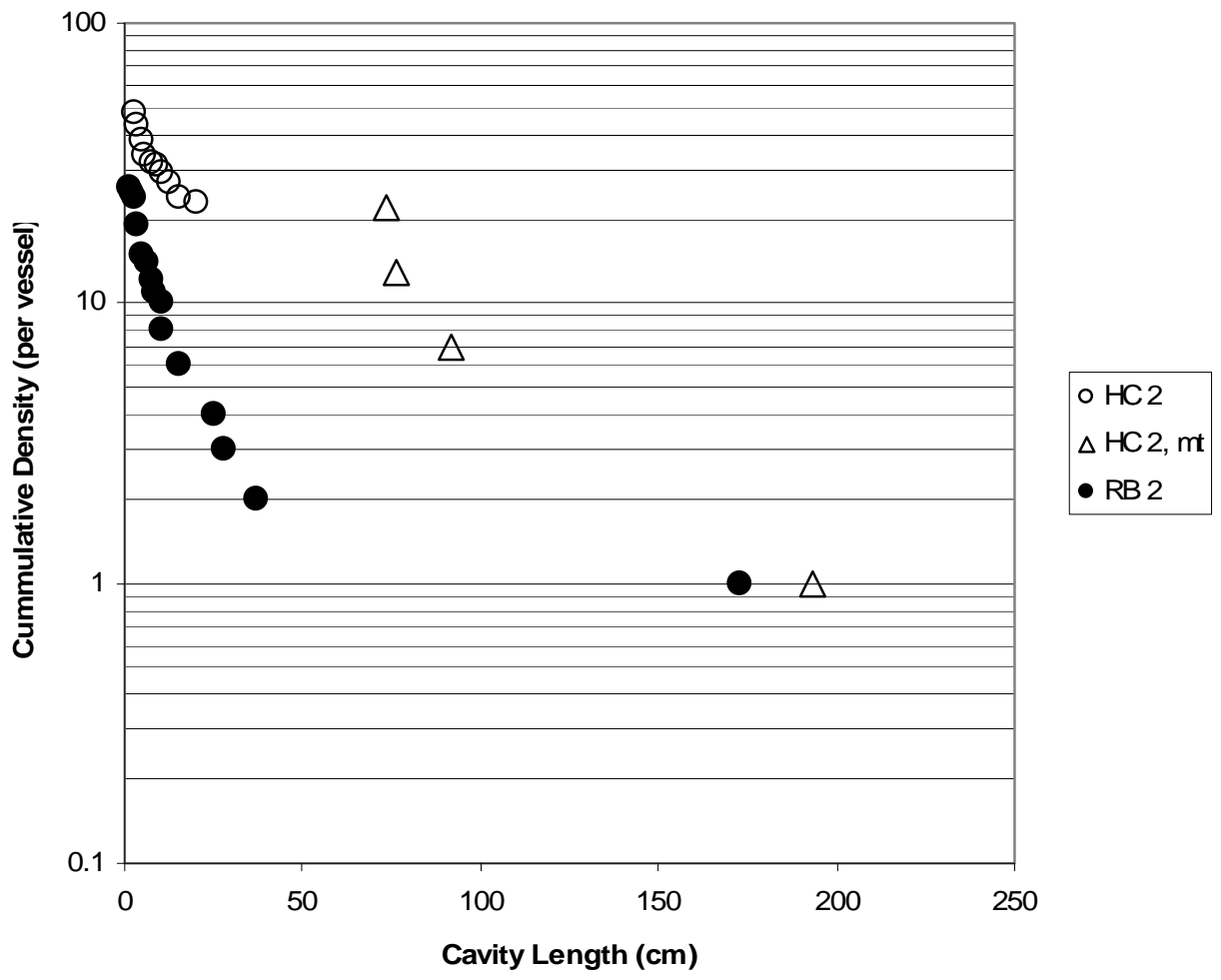

Figure 2.8 Comparison of Cavity Length for Repair of Material Handling Defects in the Hope Creek Unit 2 (HC) and River Bend Unit 2 (RB) RPVs. The data series shown as "HC, $\mathrm{mt}$ " uses the length of individual magnetic particle testing areas instead of individual cavity dimensions as described in the text.

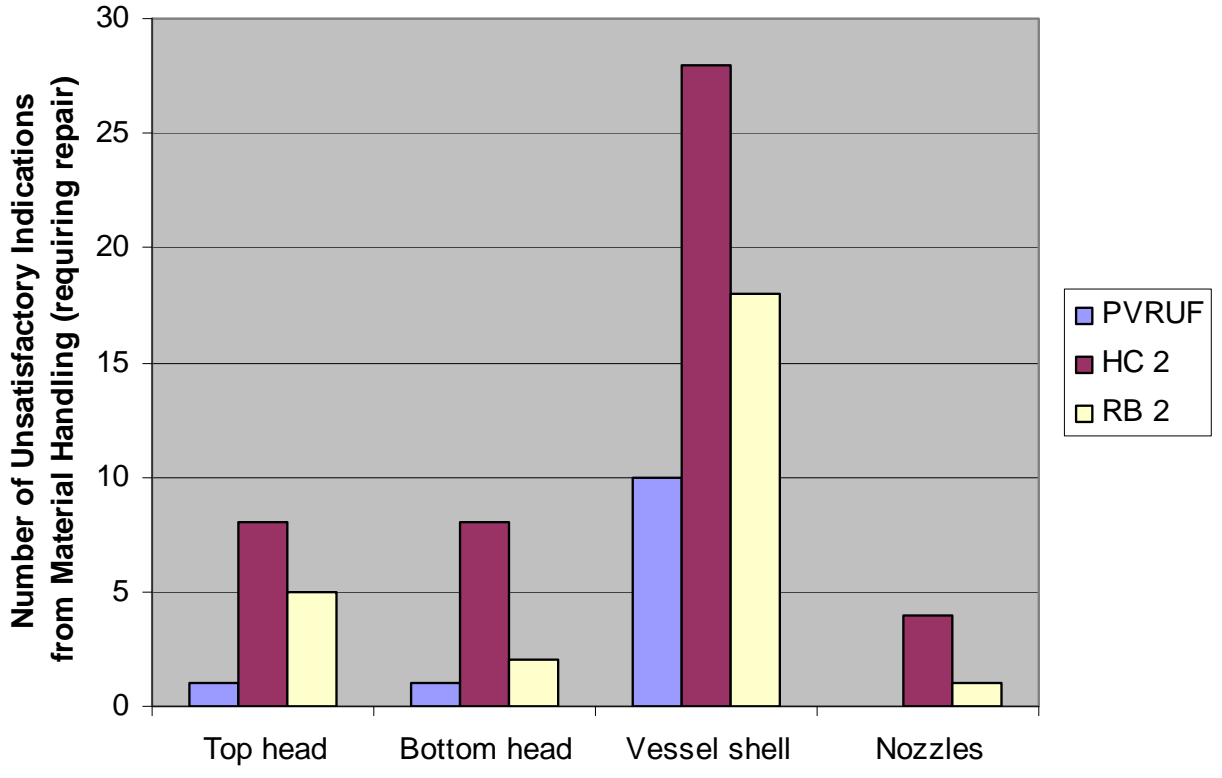

Figure 2.9 Comparison of Estimated Repair Frequency for Material Handling Defects in Three Reactor Pressure Vessels 


\subsection{RPV Seam Weld Defects and Repairs}

During fabrication, RT and UT found 86 defects in the bottom head, top head, shell, and nozzle seam welds of the Hope Creek Unit 2 vessel. Eleven defects were found in the top head, shell, and nozzle seam welds of the River Bend Unit 2 vessel. Most of the defects-84-were reported found by RT. Fifteen were detected via UT. Identification of 7 of the defects was not clearly attributable to either NDE technique; however, these 7 probably were found via UT because the radiographic records were easy to interpret and appeared complete. The ultrasonic records were sparse and consisted mostly of calibration sheets. Only one defect was reported by both RT and UT.

The length of the defects found by RT was always reported on the radiographic examination reports. Lengths of UT indications were not always given. The repair travelers documented the type and length of the welding defect (if any) found during the creation of the cavity. This information is included in this section with the dimensions of the cavity. Some of the cavity lengths are much greater than the length of the NDE indication; this can most likely be for one of two very different reasons. Either the welding flaw was longer than the NDE indication and the cavity grew to remove the flaw, or nothing was found and the length of the cavity was increased in an attempt to find a flaw that could be associated with the NDE indication. This information is included in the repair traveler.

Table 2.45 provides an overview of the seam repair and acceptable flaw information for the three RPVs. The information tables for the separate subassemblies of the vessels are listed in Table 2.45. Acceptable flaws are RT indications that are less than $13 \mathrm{~mm}$ in length.

Tables 2.46 and 2.47 list the estimated defects and acceptable indications in the seam welds of the top head of the PVRUF RPV. Table 2.48 gives estimated surface area and volume of seam weld repairs to the component.

Tables 2.49 and 2.50 list the estimated defects and acceptable indications in the seam weld defects in the bottom head of the PVRUF RPV, followed by estimated surface area and volume of seam weld repairs in Table 2.51.

Tables 2.52 through 2.56 list the estimated defects and acceptable indications in the seam weld (axial and girth seams) of the shell of the PVRUF RPV and provide the estimated surface area and volume of the related seam weld repairs.

Tables 2.57 through 2.59 list the seam weld defects and acceptable indications in the nozzle to vessel welds of the PVRUF RPV. The estimated surface area and volume of the related seam weld repairs are provided in Table 2.60 .

Table 2.61 lists the seam weld defects reported in the bottom head of the Hope Creek Unit 2 RPV. Ten defects were found by RT. The defect type shows that the flaws were slag, porosity, or a combination of the two. Table 2.62 gives the estimated repair surface area and volume and then gives weld ID and surface from which the cavity was made. The final cavity dimensions are given. The cavity lengths are sometimes significantly greater than the indication lengths reported by the NDE. 
Seam weld defects reported in the top head of the Hope Creek Unit 2 RPV are summarized in Table 2.63. Of the 28 defects reported, 25 were found in the repair process. The defects, characterized as porosity, slag, or non-fusion, were found via NDE techniques as listed in Table 2.63. Table 2.64 gives the estimated repair surface area and volume, plus weld ID and surface from which the cavity was made. The final cavity dimensions are given. The cavity lengths are sometimes significantly greater than the indication lengths reported by the NDE.

In the shell of the Hope Creek Unit 2 RPV, 35 weld seam defects were reported; 26 were found in the repair process. Table 2.65 lists the defects and the NDE technique with which each was found. The defects were porosity, slag, weld prep-line (PL) flaws, and base metal plate laminations (segmentation). The length of the flaw, where reported, is given in Table 2.65. Table 2.66 gives the estimated repair surface area and volume.

Table 2.67 lists the seam weld defects reported in the nozzles of the Hope Creek Unit 2 RPV. Thirteen defects were reported and eleven were found in the repair process. The other two repairs were performed, but no discontinuity was seen during the repair process. The defects, found via RT, were porosity, slag, and non-fusion. Table 2.68 gives the estimated repair surface area and volume as well as cavity dimensions. The cavity lengths are sometimes significantly greater than the indication lengths reported by the NDE.

Table 2.69 describes the single seam weld defect reported in the top head of the River Bend Unit 2 RPV. The defect, reported by RT, was slag. The length of the flaw is given in the table. Table 2.70 gives the estimated repair surface area and volume.

Table 2.71 lists the seam weld defects reported in the shell of the River Bend Unit 2 RPV. Seven defects were reported, and three small flaws-porosity - were found in the repair process via the NDE technique listed opposite the flaw. Table 2.72 gives the estimated repair surface area and volume.

Table 2.73 lists the seam weld defects reported in the nozzles of the River Bend Unit 2 RPV. Three defects were reported, and all were found in the repair process using the NDE technique listed opposite each defect. The defects were slag and non-fusion. Table 2.74 gives the estimated repair surface area and volume.

Seam weld flaw length distributions in the Hope Creek Unit 2 and River Bend Unit 2 RPVs are compared in Figure 2.10. The flaw length distribution for flaws found during the repair process is shown to emphasize the change in weld quality between the vessels. Changes in the weld procedure specification, the quality of the weld materials, and other factors may explain the different defect densities in the seam welds for the two vessels.

Figure 2.11 shows a comparison of flaw length in the seam welds of all three RPVs. The first $5 \mathrm{~cm}$ of length for the cumulative flaw density for PVRUF, Hope Creek Unit 2, and River Bend Unit 2 are shown. The exponential fits from Figure 2.10 are shown again. The cumulative length data for acceptable nonporosity indications found in PVRUF by RT also are shown. The PVRUF data are divided into two distributions-less than $13 \mathrm{~mm}$ and greater $13 \mathrm{~mm}$. Most radiographic indications greater than $13 \mathrm{~mm}$ long were repaired and not reported (because they were removed) in the RT indication data, so the data points for that distribution in Figure 2.11 are artificially low. For acceptable nonporosity with lengths less than $1 \mathrm{~cm}$, the distributions for PVRUF and Hope Creek Unit 2 RPV are similar. Figure 2.12 
provides a comparison of estimated repair frequency for the seam welds in the three RPVs. The estimated frequency of repair to the seam welds of PVRUF is higher than that for River Bend Unit 2 and lower than that for Hope Creek Unit 2.

Table 2.45 Construction Record Contents for Seam Repairs and Acceptable Indications in Three Vessels

\begin{tabular}{|l|l|l|l||}
\hline & \multicolumn{1}{|c|}{ PVRUF } & \multicolumn{1}{|c||}{ Hope Creek Unit 2 } & River Bend Unit 2 \\
\hline Bottom head & Tables 2.49, 2.50, and 2.51 & Tables 2.61 and 2.62 & (None) \\
\hline Top head & Tables 2.46, 2.47, and 2.48 & Tables 2.63 and 2.64 & Tables 2.69 and 2.70 \\
\hline Shell & Tables 2.52, 2.53, 2.54, 2.55, and 2.56 & Tables 2.65 and 2.66 & Tables 2.71 and 2.72 \\
\hline Nozzles & Tables 2.57, 2.58, 2.59, and 2.60 & Tables 2.67 and 2.68 & Tables 2.73 and 2.74 \\
\hline
\end{tabular}

Table 2.46 Unsatisfactory Inspections (Requiring Repair) in Seam Weld of the Top Head of the PVRUF RPV

\begin{tabular}{|c|c|c|c|c|c||}
\hline No. & NDE & $\begin{array}{c}\text { Indication } \\
\text { Type }\end{array}$ & $\begin{array}{c}\text { Length } \\
\text { (cm) }\end{array}$ & $\begin{array}{c}\text { Inspection } \\
\text { ID }\end{array}$ & Job ID \\
\hline 1 & RT & (Not given) & (Not given) & A131628 & $750101-010$ \\
\hline 2 & RT & (Not given) & (Not given) & $\mathrm{A} 131628$ & $750101-010$ \\
\hline 3 & RT & (Not given) & (Not given) & A106139 & $750104-070$ \\
\hline 4 & MT & (Not given) & (Not given) & A107839 & $750104-065$ \\
\hline
\end{tabular}

Table 2.47 Acceptable Flaws in Seam Weld of the Top Head of the PVRUF RPV

\begin{tabular}{|c|c|l|c|c|c||}
\hline No. & NDE & $\begin{array}{c}\text { Indication } \\
\text { Type }\end{array}$ & $\begin{array}{c}\text { Length } \\
\text { (cm) }\end{array}$ & Seam ID & Job ID \\
\hline 1 & RT & Slag & 0.5 & $101-104-D$ & $750104-070$ \\
\hline 2 & RT & Slag & 1.0 & $101-104-D$ & $750104-070$ \\
\hline 3 & RT & Slag & 0.5 & $101-104-D$ & $750104-070$ \\
\hline 4 & RT & Slag & 0.6 & $101-104-D$ & $750104-070$ \\
\hline 5 & RT & Porosity & & $101-104-D$ & $750104-070$ \\
\hline 6 & RT & Porosity & & $103-101$ & $750101-010$ \\
\hline 7 & RT & Slag & 0.6 & $103-101$ & $750101-010$ \\
\hline 8 & RT & Slag & 0.8 & $103-101$ & $750101-010$ \\
\hline 9 & RT & Porosity & & $103-101$ & $750101-010$ \\
\hline 10 & RT & Slag & 1.1 & $103-101$ & $750101-010$ \\
\hline 11 & RT & Porosity & & $103-101$ & $750101-010$ \\
\hline 12 & RT & Slag & 1.4 & $103-101$ & $750101-010$ \\
\hline 13 & RT & Slag & 1.4 & $103-101$ & $750101-010$ \\
\hline \hline
\end{tabular}


Table 2.48 Estimated Surface Area and Volume of Seam Weld Repairs to the Top Head of the PVRUF RPV

\begin{tabular}{|c|c|c|c|c|c|c|c|c|c|}
\hline \multirow[b]{2}{*}{ No. } & \multirow[b]{2}{*}{ Weld } & \multirow[b]{2}{*}{ ID/OD } & \multicolumn{3}{|c|}{ Cavity Dimensions } & \multicolumn{2}{|c|}{ Volume } & \multicolumn{2}{|c|}{ Surface Area } \\
\hline & & & $\begin{array}{c}\text { Length } \\
\text { (cm) }\end{array}$ & $\begin{array}{l}\text { Width } \\
\text { (cm) }\end{array}$ & $\begin{array}{l}\text { Depth } \\
\text { (cm) }\end{array}$ & $\begin{array}{c}\text { Bounding } \\
\left(\mathrm{cm}^{3}\right)\end{array}$ & $\begin{array}{c}\text { Corrected } \\
\left(\mathrm{cm}^{3}\right)\end{array}$ & $\begin{array}{c}\text { Bounding } \\
\left(\mathrm{cm}^{2}\right)\end{array}$ & $\begin{array}{c}\text { Corrected } \\
\left(\mathrm{cm}^{2}\right)\end{array}$ \\
\hline 1 & 101-101 & OD & 143.2 & (Not given) & (Not given) & & & & \\
\hline 2 & 101-104D & OD & 22.9 & 6.1 & 18.0 & $2,514.4$ & $1,676.3$ & $1,183.7$ & 712.9 \\
\hline
\end{tabular}

Table 2.49 Unsatisfactory Inspections (Requiring Repair) in Seam Weld of the Bottom Head of the PVRUF RPV

\begin{tabular}{||c|c|c|c|c|c||}
\hline No. & NDE & Defect Type & Length (cm) & Inspection ID & Job ID \\
\hline 1 & RT & (Not given) & (Not given) & A131610 & RN 2046-78 \\
\hline 2 & RT & (Not given) & (Not given) & A116732 & $750151-005$ \\
\hline 3 & RT & (Not given) & (Not given) & A106037 & $750154-060$ \\
\hline
\end{tabular}

Table 2.50 Acceptable Flaws in Seam Weld of the Bottom Head of the PVRUF RPV

\begin{tabular}{|r|c|l|c|c|c||}
\hline \hline No. & NDE & Indication Type & Length (cm) & Seam ID & Job ID \\
\hline 1 & RT & Porosity & & $101-154-A$ & $750154-060$ \\
\hline 2 & RT & Slag & 1.3 & $101-154-A$ & $750154-060$ \\
\hline 3 & RT & Porosity & & $101-154-A$ & $750154-060$ \\
\hline 4 & RT & Porosity & & $101-154-B$ & $750154-060$ \\
\hline 5 & RT & Porosity & & $101-154-B$ & $750154-060$ \\
\hline 6 & RT & Porosity & & $101-154-B$ & $750154-060$ \\
\hline 7 & RT & Slag & 1.0 & $101-154-B$ & $750154-060$ \\
\hline 8 & RT & Porosity & & $101-154-C$ & $750154-060$ \\
\hline 9 & RT & Porosity & & $101-154-C$ & $750154-060$ \\
\hline 10 & RT & Porosity & & $101-154-D$ & $750154-060$ \\
\hline 11 & RT & Slag & 1.3 & $101-154-\mathrm{D}$ & $750154-060$ \\
\hline 12 & RT & Slag & 0.6 & $101-154-\mathrm{D}$ & $750154-060$ \\
\hline 13 & RT & Slag & 0.8 & $101-154-\mathrm{D}$ & $750154-060$ \\
\hline 14 & RT & Porosity & & $101-154-\mathrm{D}$ & $750154-060$ \\
\hline 15 & RT & Porosity & $102-151$ & $750151-005$ \\
\hline 16 & RT & Slag & & $102-151$ & $750151-005$ \\
\hline 17 & RT & Porosity & & $102-151$ & $750151-005$ \\
\hline 18 & RT & Porosity & & $102-151$ & $750151-005$ \\
\hline \hline
\end{tabular}


Table 2.51 Estimated Surface Area and Volume of Seam Weld Repairs in the Bottom Head of the PVRUF RPV

\begin{tabular}{|c|c|c|c|c|c|c|c|c|c|}
\hline \multirow[b]{2}{*}{ No. } & \multirow[b]{2}{*}{ Weld } & \multirow[b]{2}{*}{ ID/OD } & \multicolumn{3}{|c|}{ "Cavity Dimensions } & \multicolumn{2}{|c|}{ Volume } & \multicolumn{2}{|c|}{ Surface Area } \\
\hline & & & $\begin{array}{c}\text { Length } \\
\text { (cm) }\end{array}$ & $\begin{array}{c}\text { Width } \\
\text { (cm) }\end{array}$ & $\begin{array}{c}\text { Depth } \\
\text { (cm) }\end{array}$ & $\begin{array}{c}\text { Bounding } \\
\left(\mathrm{cm}^{3}\right)\end{array}$ & $\begin{array}{c}\text { Corrected } \\
\left(\mathrm{cm}^{3}\right)\end{array}$ & $\begin{array}{c}\text { Bounding } \\
\left(\mathrm{cm}^{2}\right)\end{array}$ & $\begin{array}{c}\text { Corrected } \\
\left(\mathrm{cm}^{2}\right)\end{array}$ \\
\hline 1 & $101-154 \mathrm{~A}$ & ID & 48.0 & 5.3 & 10.9 & $2,773.0$ & $1,848.6$ & $1,416.3$ & 882.4 \\
\hline 2 & $101-154 \mathrm{~A}$ & ID & 15.2 & 3.8 & 2.8 & 161.7 & 107.8 & 164.2 & 92.0 \\
\hline 3 & $101-154 \mathrm{~A}$ & ID & 8.4 & 1.3 & 1.3 & 14.2 & 9.5 & 36.1 & 21.0 \\
\hline 4 & 101-154B & ID & 25.9 & 6.1 & 12.7 & $2,006.5$ & $1,337.6$ & 970.8 & 574.6 \\
\hline 5 & 101-154C & ID & 14.5 & 3.8 & 4.8 & 264.5 & 176.3 & 230.8 & 131.2 \\
\hline 6 & 101-154D & ID & 20.3 & 5.6 & 7.6 & 864.0 & 576.0 & 507.0 & 288.6 \\
\hline 7 & 101-154D & ID & 31.2 & 6.6 & 13.0 & $2,677.0$ & $1,784.6$ & $1,188.7$ & 707.0 \\
\hline 8 & 101-154D & ID & 35.0 & 7.1 & 14.7 & $3,653.0$ & $2,435.3$ & $1,486.2$ & 890.0 \\
\hline 9 & 101-154D & OD & 26.9 & 6.4 & 8.6 & $1,480.6$ & 987.1 & 744.9 & 428.0 \\
\hline 10 & 101-154D & OD & 15.7 & 4.6 & 2.5 & 180.6 & 120.4 & 173.7 & 96.5 \\
\hline
\end{tabular}

Table 2.52 Unsatisfactory Inspections (Requiring Repair) in Seam Weld in the Shell of the PVRUF RPV

\begin{tabular}{||c|c|c|c|c|c||}
\hline No. & NDE & Defect Type & Length (cm) & Inspection ID & Job ID \\
\hline 1 & RT & (Not given) & (Not given) & A131845 & $750141-008$ \\
\hline 2 & RT & (Not given) & (Not given) & A106061 & $750142-080$ \\
\hline 3 & RT & (Not given) & (Not given) & A085427 & $750122-065$ \\
\hline 4 & RT & (Not given) & (Not given) & A085398 & $750124-080$ \\
\hline 5 & MT & (Not given) & (Not given) & A012425 & $750171-013$ \\
\hline 6 & MT & (Not given) & (Not given) & A005542 & $750141-010$ \\
\hline 7 & UT & (Not given) & (Not given) & C14418 & $750141-008$ \\
\hline
\end{tabular}


Table 2.53 Acceptable Flaws in Seam Weld of the Long (Axial) Seams of the Shell of the PVRUF RPV

\begin{tabular}{|r|c|l|c|c|c||}
\hline No. & NDE & $\begin{array}{c}\text { Indication } \\
\text { Type }\end{array}$ & $\begin{array}{c}\text { Length } \\
\text { (cm) }\end{array}$ & Seam ID & Job ID \\
\hline 1 & RT & lag & 1.0 & $101-122-A$ & $750122-065$ \\
\hline 2 & RT & Porosity & & $101-122-B$ & $750122-065$ \\
\hline 3 & RT & Slag & 1.4 & $101-122-B$ & $750122-065$ \\
\hline 4 & RT & Slag & 0.6 & $101-122-C$ & $750122-065$ \\
\hline 5 & RT & Porosity & & $101-122-C$ & $750122-065$ \\
\hline 6 & RT & Porosity & & $101-124-A$ & $750124-080$ \\
\hline 7 & RT & Slag & 1.0 & $101-124-A$ & $750124-080$ \\
\hline 8 & RT & Porosity & & $101-124-A$ & $750124-080$ \\
\hline 9 & RT & Porosity & & $101-124-B$ & $750124-080$ \\
\hline 10 & RT & Porosity & & $101-124-B$ & $750124-080$ \\
\hline 11 & RT & Porosity & & $101-124-B$ & $750124-080$ \\
\hline 12 & RT & Porosity & & $101-124-B$ & $750124-080$ \\
\hline 13 & RT & Slag & 0.5 & $101-124-C$ & $750124-080$ \\
\hline 14 & RT & Porosity & & $101-124-C$ & $750124-080$ \\
\hline 15 & RT & Porosity & & $101-124-C$ & $750124-080$ \\
\hline 16 & RT & Slag & 1.3 & $101-142-A$ & $750142-080$ \\
\hline 17 & RT & Porosity & & $101-142-A$ & $750142-080$ \\
\hline 18 & RT & Porosity & & $101-142-A$ & $750142-080$ \\
\hline 19 & RT & Porosity & & $101-142-B$ & $750142-080$ \\
\hline 20 & RT & Porosity & & $101-142-B$ & $750142-080$ \\
\hline 21 & RT & Porosity & & $101-142-B$ & $750142-080$ \\
\hline 22 & RT & Porosity & & $101-142-C$ & $750142-080$ \\
\hline 23 & RT & Porosity & & $101-142-C$ & $750142-080$ \\
\hline 24 & RT & Slag & 0.6 & $101-142-C$ & $750142-080$ \\
\hline
\end{tabular}

Table 2.54 Estimated Surface Area and Volume of Seam Weld Repairs in the Long (Axial) Seams of the Shell of the PVRUF RPV

\begin{tabular}{|c|c|c|c|c|c|c|c|c|c|}
\hline \multirow[b]{2}{*}{ No. } & \multirow[b]{2}{*}{ Weld } & \multirow[b]{2}{*}{ ID/OD } & \multicolumn{3}{|c|}{ Cavity Dimensions } & \multicolumn{2}{|c|}{ Volume } & \multicolumn{2}{|c|}{ Surface Area } \\
\hline & & & $\begin{array}{c}\text { Length } \\
\text { (cm) }\end{array}$ & $\begin{array}{c}\text { Width } \\
\text { (cm) }\end{array}$ & $\begin{array}{l}\text { Depth } \\
\text { (cm) }\end{array}$ & $\begin{array}{c}\text { Bounding } \\
\left(\mathrm{cm}^{3}\right)\end{array}$ & $\begin{array}{c}\text { Corrected } \\
\left(\mathrm{cm}^{3}\right)\end{array}$ & $\begin{array}{c}\text { Bounding } \\
\left(\mathrm{cm}^{2}\right)\end{array}$ & $\begin{array}{c}\text { Corrected } \\
\left(\mathrm{cm}^{2}\right)\end{array}$ \\
\hline 1 & 101-122B & OD & 7.6 & 2.5 & 1.3 & 24.7 & 16.5 & 45.3 & 25.0 \\
\hline 2 & 101-124B & OD & 22.4 & 5.1 & 8.6 & 982.5 & 655.0 & 587.2 & 343.5 \\
\hline 3 & 101-142B & ID & 23.9 & 6.6 & 11.9 & $1,877.1$ & $1,251.4$ & 883.6 & 511.3 \\
\hline
\end{tabular}


Table 2.55 Acceptable Flaws in the Seam Weld in the Girth Seams of the Shell of the PVRUF RPV

\begin{tabular}{|r|c|l|c|c|c||}
\hline No. & NDE & $\begin{array}{c}\text { Indication } \\
\text { Type }\end{array}$ & $\begin{array}{c}\text { Length } \\
\text { (cm) }\end{array}$ & Seam ID & Job ID \\
\hline 1 & RT & Porosity & & $101-121$ & $750121-010$ \\
\hline 2 & RT & Slag & 1.4 & $101-121$ & $750121-010$ \\
\hline 3 & RT & Porosity & & $101-121$ & $750121-010$ \\
\hline 4 & RT & Porosity & & $101-121$ & $750121-010$ \\
\hline 5 & RT & Slag & 1.3 & $101-121$ & $750121-010$ \\
\hline 6 & RT & Slag & 1.3 & $101-121$ & $750121-010$ \\
\hline 7 & RT & Porosity & & $103-121$ & $750121-010$ \\
\hline 8 & RT & Porosity & & $101-171$ & $750171-020$ \\
\hline 9 & RT & Porosity & & $101-171$ & $750171-020$ \\
\hline 10 & RT & Porosity & & $101-171$ & $750171-020$ \\
\hline 11 & RT & Porosity & & $101-171$ & $750171-020$ \\
\hline 12 & RT & Porosity & & $101-171$ & $750171-020$ \\
\hline 13 & RT & Porosity & & $101-171$ & $750171-020$ \\
\hline 14 & RT & Porosity & & $101-171$ & $750171-020$ \\
\hline 15 & RT & Porosity & & $101-171$ & $750171-020$ \\
\hline 16 & RT & Porosity & & $101-171$ & $750171-020$ \\
\hline 17 & RT & Porosity & & $101-171$ & $750171-020$ \\
\hline 18 & RT & Slag & 1.0 & $101-171$ & $750171-020$ \\
\hline 19 & RT & Porosity & & $101-171$ & $750171-020$ \\
\hline 20 & RT & Porosity & & $101-171$ & $750171-020$ \\
\hline 21 & RT & Porosity & & $101-171$ & $750171-020$ \\
\hline 22 & RT & Porosity & & $101-171$ & $750171-020$ \\
\hline 23 & RT & Porosity & & $101-171$ & $750171-020$ \\
\hline 24 & RT & Porosity & & $101-171$ & $750171-020$ \\
\hline 25 & RT & Porosity & & $101-171$ & $750171-020$ \\
\hline 26 & RT & Porosity & & $101-171$ & $750171-020$ \\
\hline 27 & RT & Porosity & & $101-171$ & $750171-020$ \\
\hline 28 & RT & Porosity & & $101-171$ & $750171-020$ \\
\hline 29 & RT & Porosity & & $101-171$ & $750171-020$ \\
\hline 30 & RT & Porosity & & $101-171$ & $750171-020$ \\
\hline 31 & RT & Porosity & & $101-171$ & $750171-020$ \\
\hline 32 & RT & Porosity & & $101-141$ & $750141-008$ \\
\hline 33 & RT & Slag & 0.6 & $101-141$ & $750141-008$ \\
\hline 34 & RT & Porosity & & $101-141$ & $750141-008$ \\
\hline 35 & RT & Slag & 0.3 & $101-141$ & $750141-008$ \\
\hline 36 & RT & Slag & 1.1 & $101-141$ & $750141-008$ \\
\hline 37 & RT & Porosity & & $101-141$ & $750141-008$ \\
\hline 38 & RT & Porosity & & $101-141$ & $750141-008$ \\
\hline 39 & RT & Porosity & & $101-141$ & $750141-008$ \\
\hline 40 & RT & Slag & 0.5 & $101-141$ & $750141-008$ \\
\hline
\end{tabular}


Table 2.56 Estimated Surface Area and Volume of Seam Weld Repairs in the Girth Seams of the Shell of the PVRUF RPV

\begin{tabular}{|c|c|c|c|c|c|c|c|c|c|}
\hline \multirow[b]{2}{*}{ No. } & \multirow[b]{2}{*}{ Weld } & \multirow[b]{2}{*}{ ID/OD } & \multicolumn{3}{|c|}{ "Cavity Dimensions } & \multicolumn{2}{|c|}{ Volume } & \multicolumn{2}{|c|}{ Surface Area } \\
\hline & & & $\begin{array}{c}\text { Length } \\
\text { (cm) }\end{array}$ & $\begin{array}{l}\text { Width } \\
\text { (cm) }\end{array}$ & $\begin{array}{l}\text { Depth } \\
\text { (cm) }\end{array}$ & $\begin{array}{c}\text { Bounding } \\
\left(\mathrm{cm}^{3}\right)\end{array}$ & $\begin{array}{c}\text { Corrected } \\
\left(\mathrm{cm}^{3}\right)\end{array}$ & $\begin{array}{c}\text { Bounding } \\
\left(\mathrm{cm}^{2}\right)\end{array}$ & $\begin{array}{c}\text { Corrected } \\
\left(\mathrm{cm}^{2}\right)\end{array}$ \\
\hline 1 & $101-171$ & OD & 30.2 & 6.1 & 16.5 & $3,039.6$ & $2,026.4$ & $1,382.1$ & 844.8 \\
\hline 2 & $101-171$ & ID & 4.1 & 2.0 & 0.8 & 6.6 & 4.4 & 18.0 & 9.8 \\
\hline 3 & $101-171$ & ID & 19.3 & 3.0 & 1.3 & 75.3 & 50.2 & 115.9 & 67.5 \\
\hline 4 & $101-171$ & ID & 16.3 & 2.0 & 0.5 & 16.3 & 10.9 & 50.9 & 30.7 \\
\hline 5 & $101-171$ & ID & 6.4 & 1.0 & 0.5 & 3.2 & 2.1 & 13.8 & 8.0 \\
\hline 6 & $101-141$ & OD & 28.4 & 6.4 & 8.9 & $1,617.7$ & $1,078.4$ & 801.2 & 463.0 \\
\hline 7 & $101-141$ & ID & 33.0 & 10.7 & 8.6 & $3,036.7$ & $2,024.4$ & $1,104.7$ & 609.0 \\
\hline 8 & $101-141$ & ID & 25.9 & 8.9 & 6.6 & $1,521.4$ & $1,014.2$ & 689.9 & 378.4 \\
\hline
\end{tabular}

Table 2.57 Unsatisfactory Inspections (Requiring Repair) in Nozzle to Vessel Welds of the PVRUF RPV

\begin{tabular}{|c|c|c|c|c|c||}
\hline \hline No. & NDE & Defect Type & Length (cm) & Inspection ID & Job ID \\
\hline 1 & RT & (Not given) & (Not given) & A131587 & $750121-080$ \\
\hline 2 & RT & (Not given) & (Not given) & A131587 & $750121-080$ \\
\hline
\end{tabular}

Table 2.58 Acceptable Flaws in Inlet Nozzle to Vessel Welds of the PVRUF RPV

\begin{tabular}{|r|c|l|c|c|c||}
\hline No. & NDE & $\begin{array}{c}\text { Indication } \\
\text { Type }\end{array}$ & Length (cm) & Seam ID & Job ID \\
\hline 1 & RT & Porosity & & $105-121-A$ & $750121-030$ \\
\hline 2 & RT & Porosity & & $105-121-B$ & $750121-080$ \\
\hline 3 & RT & Slag & 1.0 & $105-121-B$ & $750121-080$ \\
\hline 4 & RT & Porosity & & $105-121-B$ & $750121-080$ \\
\hline 5 & RT & Slag & 0.6 & $105-121-B$ & $750121-080$ \\
\hline 6 & RT & Slag & 1.0 & $105-121-B$ & $750121-080$ \\
\hline 7 & RT & Slag & 1.1 & $105-121-B$ & $750121-080$ \\
\hline 8 & RT & Slag & 1.3 & $105-121-B$ & $750121-080$ \\
\hline 9 & RT & Slag & 1.1 & $105-121-B$ & $750121-080$ \\
\hline 10 & RT & Porosity & 1.1 & $105-121-C$ & $750121-080$ \\
\hline 11 & RT & Porosity & & $105-121-D$ & $750121-080$ \\
\hline 12 & RT & Porosity & & $105-121-D$ & $750121-080$ \\
\hline 13 & RT & Slag & 1.6 & $105-121-D$ & $750121-080$ \\
\hline 14 & RT & Slag & 1.0 & $105-121-D$ & $750121-080$ \\
\hline 15 & RT & Porosity & & $105-121-D$ & $750121-080$ \\
\hline 16 & RT & Slag & 1.1 & $105-121-D$ & $750121-080$ \\
\hline 17 & RT & Porosity & & $105-121-D$ & $750121-080$ \\
\hline 18 & RT & Porosity & & $105-121-D$ & $750121-080$ \\
\hline
\end{tabular}


Table 2.59 Acceptable Flaws in the Outlet Nozzle to Vessel Welds of the PVRUF RPV

\begin{tabular}{|r|c|l|c|c|c||}
\hline No. & NDE & $\begin{array}{c}\text { Indication } \\
\text { Type }\end{array}$ & Length (cm) & Seam ID & Job ID \\
\hline 1 & RT & Slag & 1.3 & $107-121-A$ & $750121-080$ \\
\hline 2 & RT & Slag & 1.6 & $107-121-A$ & $750121-080$ \\
\hline 3 & RT & Porosity & & $107-121-A$ & $750121-080$ \\
\hline 4 & RT & Slag & 1.1 & $107-121-A$ & $750121-080$ \\
\hline 5 & RT & Slag & 1.4 & $107-121-A$ & $750121-080$ \\
\hline 6 & RT & Slag & 0.5 & $107-121-A$ & $750121-080$ \\
\hline 7 & RT & Slag & 0.5 & $107-121-A$ & $750121-080$ \\
\hline 8 & RT & Porosity & & $107-121-A$ & $750121-080$ \\
\hline 9 & RT & Porosity & & $107-121-B$ & $750121-080$ \\
\hline 10 & RT & Porosity & & $107-121-B$ & $750121-080$ \\
\hline 11 & RT & Porosity & & $107-121-B$ & $750121-080$ \\
\hline 12 & RT & Porosity & & $107-121-B$ & $750121-080$ \\
\hline 13 & RT & Slag & 0.8 & $107-121-B$ & $750121-080$ \\
\hline 14 & RT & Slag & 1.3 & $107-121-B$ & $750121-080$ \\
\hline 15 & RT & Porosity & & $107-121-C$ & $750121-080$ \\
\hline 16 & RT & Porosity & & $107-121-C$ & $750121-080$ \\
\hline 17 & RT & Porosity & & $107-121-C$ & $750121-080$ \\
\hline 18 & RT & Porosity & & $107-121-D$ & $750121-080$ \\
\hline 19 & RT & Porosity & & $107-121-D$ & $750121-080$ \\
\hline 20 & RT & Porosity & & $107-121-D$ & $750121-080$ \\
\hline 21 & RT & Slag & 1.3 & $107-121-D$ & $750121-080$ \\
\hline
\end{tabular}

Table 2.60 Estimated Surface Area and Volume of Weld Repairs in the Nozzle to Vessel Welds of the PVRUF RPV

\begin{tabular}{|c|c|c|c|c|c|c|c|c|c|}
\hline \multirow[b]{2}{*}{ No. } & \multirow[b]{2}{*}{ Weld } & \multirow[b]{2}{*}{ ID/OD } & \multicolumn{3}{|c|}{ Cavity Dimensions } & \multicolumn{2}{|c|}{ Volume } & \multicolumn{2}{|c|}{ Surface Area } \\
\hline & & & $\begin{array}{l}\text { Length } \\
\text { (cm) }\end{array}$ & $\begin{array}{c}\text { Width } \\
\text { (cm) }\end{array}$ & $\begin{array}{c}\text { Depth } \\
\text { (cm) }\end{array}$ & $\begin{array}{c}\text { Bounding } \\
\left(\mathrm{cm}^{3}\right)\end{array}$ & $\begin{array}{c}\text { Corrected } \\
\left(\mathrm{cm}^{3}\right)\end{array}$ & $\begin{array}{c}\text { Bounding } \\
\left(\mathrm{cm}^{2}\right)\end{array}$ & $\begin{array}{c}\text { Corrected } \\
\left(\mathrm{cm}^{2}\right)\end{array}$ \\
\hline 1 & 107-121B & OD & 13.7 & 6.4 & 1.5 & 131.5 & 87.7 & 148.0 & 84.4 \\
\hline 2 & 107-121B & OD & 18.3 & 11.2 & 4.3 & 881.3 & 587.6 & 458.7 & 246.4 \\
\hline 3 & 107-121B & ID & 14.0 & 3.6 & 3.0 & 151.2 & 100.8 & 156.0 & 87.4 \\
\hline 4 & $107-121 \mathrm{C}$ & OD & 22.4 & 8.1 & 5.3 & 961.6 & 641.1 & 504.7 & 275.8 \\
\hline 5 & $105-121 \mathrm{C}$ & OD & 28.7 & 8.9 & 9.7 & $2,477.7$ & $1,651.8$ & 984.9 & 549.6 \\
\hline 6 & $105-121 C$ & OD & 30.0 & 13.7 & 4.1 & $1,685.1$ & $1,123.4$ & 769.3 & 429.2 \\
\hline 7 & 105-121C & OD & 33.0 & 16.3 & 5.8 & $3,119.8$ & $2,079.9$ & $1,109.8$ & 607.7 \\
\hline 8 & $105-121 \mathrm{C}$ & ID & 6.4 & 2.0 & 2.0 & 25.6 & 17.1 & 46.4 & 25.8 \\
\hline 9 & 105-121C & ID & 10.9 & 4.3 & 3.6 & 168.7 & 112.5 & 156.3 & 85.1 \\
\hline
\end{tabular}


Table 2.61 Seam Weld Defects in the Bottom Head of the Hope Creek Unit 2 RPV

\begin{tabular}{|r|c|l|c|c|}
\hline No. & NDE & \multicolumn{1}{|c|}{ Defect Type } & $\begin{array}{c}\text { Length } \\
\text { (cm) }\end{array}$ & Repair ID \\
\hline 1 & RT & Slag & 1.0 & MR-89C \\
\hline 2 & RT & Slag & 3.2 & MR-89B \\
\hline 3 & RT & Slag & 1.0 & MR-89D \\
\hline 4 & RT & Slag and porosity & 1.0 & MR-89E \\
\hline 5 & RT & Slag & 1.3 & MR-89A \\
\hline 6 & RT & Slag or porosity & 7.0 & MR-2D \\
\hline 7 & RT & Slag or porosity & 2.2 & MR-2B \\
\hline 8 & RT & Slag or porosity & 22.9 & MR-2A \\
\hline 9 & RT & Porosity & 17.8 & MR-89F \\
\hline 10 & RT & Slag or porosity & 2.5 & MR-2C \\
\hline
\end{tabular}

Table 2.62 Estimated Surface Area and Volume of Seam Weld Repairs in the Bottom Head of the Hope Creek Unit 2 RPV

\begin{tabular}{|c|c|c|c|c|c|c|c|c|c|}
\hline \multirow[b]{2}{*}{ No. } & \multirow[b]{2}{*}{ Repair ID } & \multirow[b]{2}{*}{ ID/OD } & \multicolumn{3}{|c|}{ Cavity Dimensions } & \multicolumn{2}{|c|}{ Volume } & \multicolumn{2}{|c|}{ Surface Area } \\
\hline & & & $\begin{array}{l}\text { Length } \\
\text { (cm) }\end{array}$ & $\begin{array}{c}\text { Width } \\
\text { (cm) }\end{array}$ & $\begin{array}{c}\text { Depth } \\
\text { (cm) }\end{array}$ & $\begin{array}{c}\text { Bounding } \\
\left(\mathrm{cm}^{3}\right)\end{array}$ & $\begin{array}{c}\text { Corrected } \\
\left(\mathrm{cm}^{3}\right)\end{array}$ & $\begin{array}{c}\text { Bounding } \\
\left(\mathrm{cm}^{2}\right)\end{array}$ & $\begin{array}{c}\text { Corrected } \\
\left(\mathrm{cm}^{2}\right)\end{array}$ \\
\hline 1 & MR-89C & ID & 7.0 & 2.5 & 0.8 & 14.0 & 9.3 & 32.7 & 18.4 \\
\hline 2 & MR-89B & ID & 21.6 & 2.5 & 1.3 & 70.2 & 46.8 & 116.7 & 68.5 \\
\hline 3 & MR-89D & ID & 10.8 & 7.9 & 1.1 & 93.9 & 62.6 & 126.5 & 74.9 \\
\hline 4 & MR-89E & ID & 15.9 & 6.4 & 3.2 & 325.6 & 217.1 & 244.5 & 133.1 \\
\hline 5 & MR-89A & ID & 15.2 & 10.2 & 1.6 & 248.1 & 165.4 & 236.3 & 138.5 \\
\hline 6 & MR-2D & ID & 33.0 & 8.3 & 1.9 & 520.4 & 346.9 & 430.8 & 255.0 \\
\hline 7 & MR-2B & ID & 27.9 & 6.4 & 5.7 & $1,017.8$ & 678.5 & 569.6 & 321.9 \\
\hline 8 & MR-2A & ID & 38.7 & 3.8 & 5.7 & 838.2 & 558.8 & 631.6 & 385.0 \\
\hline 9 & MR-89F & ID & 35.6 & 11.4 & 2.5 & $1,014.6$ & 676.4 & 640.8 & 376.5 \\
\hline 10 & MR-2C & OD & 23.5 & 6.7 & 13.3 & $2,094.1$ & $1,396.1$ & 960.8 & 559.1 \\
\hline
\end{tabular}


Table 2.63 Seam Weld Defects in the Top Head of the Hope Creek Unit 2 RPV

\begin{tabular}{|r|c|l|c|c||}
\hline No. & NDE & \multicolumn{1}{|c|}{ Defect Type } & $\begin{array}{c}\text { Length } \\
\text { (cm) }\end{array}$ & Repair ID \\
\hline 1 & RT & Porosity & 0.3 & MR-104C \\
\hline 2 & & Slag & 2.5 & MR-115H \\
\hline 3 & RT & Slag & 8.9 & MR-115K \\
\hline 4 & RT & Slag & 0.6 & MR-104D \\
\hline 5 & RT & Nothing found & 1.3 & MR-115C \\
\hline 6 & RT & Slag & 7.0 & MR-115A \\
\hline 7 & & Slag and non-fusion & 3.8 & MR-115F \\
\hline 8 & RT & Slag & 10.2 & MR-115J \\
\hline 9 & RT & Slag line & 10.2 & MR-115P \\
\hline 10 & RT & Slag & 5.1 & MR-115R \\
\hline 11 & RT & Slag & 1.9 & MR-115B \\
\hline 12 & RT & Slag pocket & 0.6 & MR-104E \\
\hline 13 & & Slag & 1.9 & MR-115L \\
\hline 14 & & Slag & 2.5 & MR-115E \\
\hline 15 & RT & Slag and non-fusion & 5.1 & MR-123F \\
\hline 16 & RT & Slag pocket & 9.8 & MR-104F \\
\hline 17 & RT & Non-fusion & 5.7 & MR-115D \\
\hline 18 & RT & Slag & 5.1 & MR-104G \\
\hline 19 & & Nothing found & 0.0 & MR-115Mb \\
\hline 20 & RT & Slag & 2.5 & MR-115N \\
\hline 21 & & Non fusion & 2.5 & MR-115Ma \\
\hline 22 & RT & Slag and non-fusion & 2.5 & MR-123G \\
\hline 23 & RT & Nothing found & 2.2 & MR-115Q \\
\hline 24 & & Slag pockets & 12.7 & MR-115G \\
\hline 25 & RT & Slag and non-fusion & 15.2 & MR-123AB \\
\hline 26 & RT & Slag and non-fusion & 12.7 & MR-123CD \\
\hline 27 & RT & Slag and non-fusion & 12.7 & MR-123E \\
\hline 28 & RT & Slag & 96.5 & MR-104AB \\
\hline & & & & \\
\hline
\end{tabular}


Table 2.64 Estimated Surface Area and Volume of Seam Weld Repair in the Top Head of the Hope Creek Unit 2 RPV

\begin{tabular}{|c|c|c|c|c|c|c|c|c|c|}
\hline \multirow[b]{2}{*}{ No. } & \multirow[b]{2}{*}{ Repair ID } & \multirow[b]{2}{*}{$\begin{array}{l}\text { ID/ } \\
\text { OD }\end{array}$} & \multicolumn{3}{|c|}{ "Cavity Dimensions } & \multicolumn{2}{|c|}{ Volume } & \multicolumn{2}{|c|}{ Surface Area } \\
\hline & & & $\begin{array}{c}\text { Length } \\
\text { (cm) }\end{array}$ & $\begin{array}{l}\text { Width } \\
\text { (cm) }\end{array}$ & $\begin{array}{c}\text { Depth } \\
\text { (cm) }\end{array}$ & $\begin{array}{c}\text { Bounding } \\
\left(\mathrm{cm}^{3}\right)\end{array}$ & \begin{tabular}{|c|} 
Corrected \\
$\left(\mathrm{cm}^{3}\right)$
\end{tabular} & $\begin{array}{c}\text { Bounding } \\
\left(\mathrm{cm}^{2}\right)\end{array}$ & $\begin{array}{c}\text { Corrected } \\
\left(\mathrm{cm}^{2}\right)\end{array}$ \\
\hline 1 & MR-104C & ID & 7.6 & 2.5 & 1.3 & 24.7 & 16.5 & 45.3 & 25.0 \\
\hline 2 & MR-115H & OD & 12.1 & 4.4 & 2.9 & 154.4 & 102.9 & 148.9 & 81.2 \\
\hline 3 & MR-115K & OD & 14.0 & 3.8 & 2.9 & 154.3 & 102.9 & 156.4 & 87.2 \\
\hline 4 & MR-104D & ID & 12.7 & 4.1 & 4.4 & 229.1 & 152.7 & 199.9 & 111.2 \\
\hline 5 & MR-115C & OD & 15.2 & 4.4 & 3.2 & 214.0 & 142.7 & 192.3 & 106.7 \\
\hline 6 & MR-115A & OD & 15.9 & 5.1 & 3.2 & 259.5 & 173.0 & 215.5 & 118.8 \\
\hline 7 & MR-115F & OD & 17.1 & 5.7 & 2.5 & 243.7 & 162.5 & 211.5 & 117.5 \\
\hline 8 & MR-115J & OD & 19.4 & 3.8 & 3.2 & 234.3 & 159.3 & 221.0 & 152.9 \\
\hline 9 & MR-115P & ID & 19.1 & 4.4 & 4.4 & 369.8 & 246.5 & 290.8 & 164.9 \\
\hline 10 & MR-115R & OD & 15.2 & 5.1 & 7.0 & 542.6 & 361.8 & 361.7 & 202.9 \\
\hline 11 & MR-115B & OD & 17.8 & 5.7 & 5.7 & 578.3 & 385.5 & 369.4 & 205.0 \\
\hline 12 & MR-104E & ID & 18.4 & 3.8 & 6.7 & 468.5 & 312.3 & 367.4 & 217.2 \\
\hline 13 & MR-115L & OD & 20.3 & 6.4 & 5.1 & 662.6 & 441.7 & 402.3 & 222.1 \\
\hline 14 & MR-115E & OD & 21.6 & 6.0 & 6.0 & 777.6 & 518.4 & 460.8 & 258.2 \\
\hline 15 & MR-123F & OD & 25.4 & 5.1 & 6.4 & 829.1 & 552.7 & 519.9 & 300.9 \\
\hline 16 & MR-104F & ID & 23.5 & 6.0 & 7.0 & 987.0 & 658.0 & 554.0 & 314.3 \\
\hline 17 & MR-115D & ID & 22.2 & 6.7 & 7.6 & $1,130.4$ & 753.6 & 588.0 & 329.3 \\
\hline 18 & MR-104G & ID & 21.6 & 8.3 & 7.6 & $1,362.5$ & 908.4 & 633.8 & 346.5 \\
\hline 19 & MR-115Mb & OD & 24.8 & 7.0 & 7.6 & $1,319.4$ & 879.6 & 657.0 & 368.9 \\
\hline 20 & MR-115N & ID & 30.5 & 5.6 & 8.3 & $1,417.6$ & 945.1 & 770.1 & 453.1 \\
\hline 21 & MR-115Ma & ID & 29.2 & 8.3 & 7.9 & $1,914.6$ & $1,276.4$ & 834.9 & 466.2 \\
\hline 22 & MR-123G & OD & 31.1 & 7.6 & 7.6 & $1,796.3$ & $1,197.6$ & 824.6 & 465.9 \\
\hline 23 & MR-115Q & OD & 29.8 & 8.9 & 9.5 & $2,519.6$ & $1,679.7$ & $1,000.5$ & 559.2 \\
\hline 24 & MR-115G & OD & 34.3 & 7.6 & 8.3 & $2,163.6$ & $1,442.4$ & 956.2 & 545.7 \\
\hline 25 & MR-123AB & OD & 40.6 & 7.0 & 7.6 & $2,159.9$ & $1,439.9$ & $1,007.7$ & 583.9 \\
\hline 26 & MR-123CD & OD & 42.5 & 7.9 & 8.3 & $2,786.7$ & $1,857.8$ & $1,172.4$ & 675.2 \\
\hline 27 & MR-123E & OD & 40.6 & 7.0 & 9.5 & $2,699.9$ & $1,799.9$ & $1,188.6$ & 697.9 \\
\hline 28 & MR-104AB & ID & 137.2 & 7.0 & 9.5 & $9,123.8$ & $6,082.5$ & $3,700.2$ & $2,289.1$ \\
\hline
\end{tabular}


Table 2.65 Seam Weld Defects in the Shell of the Hope Creek Unit 2 RPV

\begin{tabular}{|c|c|c|c|c|}
\hline No. & NDE & Defect Type & Length (cm) & Repair ID \\
\hline 1 & RT & Not found & 1.3 & MR-105D \\
\hline 2 & RT & Holes & 2.5 & MR-105C \\
\hline 3 & RT & Slag & 1.6 & MR-105A \\
\hline 4 & RT & Not found & 1.3 & MR-105E \\
\hline 5 & RT & Broken up porosity & 1.3 & MR-71-B \\
\hline 6 & RT & Slag & 1.3 & MR-113B \\
\hline 7 & RT & Slag & 2.5 & MR-105G \\
\hline 8 & RT & & 2.5 & MR-64D \\
\hline 9 & RT & PL defect & 1.3 & MR-62D \\
\hline 10 & RT & Slag & 10.2 & MR-105F \\
\hline 11 & UT & Planar indication with TWD of 0.125 in. & 1.3 & MR-11 \\
\hline 12 & RT & Slag (half in. long) & 2.5 & MR-35B \\
\hline 13 & RT & Slag & 6.4 & MR-113A \\
\hline 14 & RT & & 1.3 & MR-64B \\
\hline 15 & UT & Slag & & MR-64B \\
\hline 16 & RT & & 3.8 & MR-64A \\
\hline 17 & RT & Slag & 1.3 & MR-37 \\
\hline 18 & RT & Light and broken slag line & 5.1 & MR-113E \\
\hline 19 & UT & Slag & & MR-63D \\
\hline 20 & UT & Slag & & MR-63K \\
\hline 21 & RT & Slag & 2.5 & MR-64F \\
\hline 22 & RT & Slag & 1.3 & MR-35A \\
\hline 23 & RT & Slag & 2.5 & MR-63E \\
\hline 24 & RT & & 1.3 & MR-64E \\
\hline 25 & RT & Small slag spots & 5.1 & MR-113D \\
\hline 26 & RT & Slag & 3.8 & MR-64C \\
\hline 27 & UT & PL defect and segmentation & & MR-62A \\
\hline 28 & RT \& UT & Slag & 30.5 & MR-63HJ \\
\hline 29 & UT & & & MR-62J \\
\hline 30 & RT & Slag & 10.2 & MR-113F \\
\hline 31 & UT & Not found & & MR-63A \\
\hline 32 & UT & PL defect & & MR-62C \\
\hline 33 & RT & Sot found & 5.1 & MR-105B \\
\hline 34 & RT & Slag pocket & 1.3 & MR-113C \\
\hline 35 & UT & PL defect and segmentation & & MR-62EF \\
\hline
\end{tabular}


Table 2.66 Estimated Surface Area and Volume of Seam Weld Repair in the Shell of the Hope Creek Unit 2 RPV

\begin{tabular}{|c|c|c|c|c|c|c|c|c|c|}
\hline \multirow[b]{2}{*}{ No. } & \multirow[b]{2}{*}{ Repair ID } & \multirow[b]{2}{*}{$\begin{array}{l}\text { ID/ } \\
\text { OD }\end{array}$} & \multicolumn{3}{|c|}{ Cavity Dimensions } & \multicolumn{2}{|c|}{ Volume } & \multicolumn{2}{|c|}{ "Surface Area } \\
\hline & & & $\begin{array}{c}\text { Length } \\
\text { (cm) }\end{array}$ & $\begin{array}{c}\text { Width } \\
\text { (cm) }\end{array}$ & $\begin{array}{c}\text { Depth } \\
\text { (cm) }\end{array}$ & $\begin{array}{c}\text { Bounding } \\
\left(\mathrm{cm}^{3}\right)\end{array}$ & $\begin{array}{c}\text { Corrected } \\
\left(\mathrm{cm}^{3}\right)\end{array}$ & $\begin{array}{c}\text { Bounding } \\
\left(\mathrm{cm}^{2}\right)\end{array}$ & $\begin{array}{c}\text { Corrected } \\
\left(\mathrm{cm}^{2}\right)\end{array}$ \\
\hline 1 & MR-105D & ID & 5.7 & 2.5 & 1.0 & 14.3 & 9.5 & 30.7 & 16.8 \\
\hline 2 & MR-105C & ID & 8.9 & 2.2 & 1.0 & 19.6 & 13.1 & 41.8 & 23.6 \\
\hline 3 & MR-105A & OD & 5.1 & 6.4 & 1.3 & 42.4 & 28.3 & 62.5 & 34.1 \\
\hline 4 & MR-105E & ID & 10.2 & 3.5 & 2.5 & 89.3 & 59.5 & 104.2 & 57.2 \\
\hline 5 & MR-71-B & OD & 13.7 & 4.4 & 4.1 & 247.1 & 164.8 & 208.7 & 115.5 \\
\hline 6 & MR-113B & ID & 15.2 & 6.4 & 5.1 & 496.1 & 330.8 & 317.6 & 172.1 \\
\hline 7 & MR-105G & OD & 21.0 & 7.3 & 5.1 & 781.8 & 521.2 & 442.0 & 242.2 \\
\hline 8 & MR-64D & ID & 26.7 & 5.4 & 5.1 & 735.3 & 490.2 & 471.6 & 269.1 \\
\hline 9 & MR-62D & OD & 21.9 & 5.7 & 7.0 & 873.8 & 582.5 & 511.2 & 290.4 \\
\hline 10 & MR-105F & ID & 26.0 & 4.1 & 7.6 & 810.2 & 540.1 & 564.1 & 341.0 \\
\hline 11 & MR-11 & OD & 33.0 & 5.7 & 4.8 & 902.9 & 601.9 & 559.6 & 321.3 \\
\hline 12 & MR-35B & OD & 27.6 & 7.3 & 5.7 & $1,136.0$ & 757.3 & 593.7 & 331.4 \\
\hline 13 & MR-113A & ID & 24.1 & 7.3 & 7.6 & $1,337.1$ & 891.4 & 653.2 & 364.4 \\
\hline 14 & MR-64B & ID & 29.5 & 7.6 & 5.2 & $1,165.8$ & 777.2 & 610.0 & 341.1 \\
\hline 15 & MR-63B & OD & 23.2 & 7.0 & 9.2 & $1,494.1$ & 996.1 & 718.1 & 405.1 \\
\hline 16 & MR-64A & OD & 26.7 & 8.9 & 6.7 & $1,592.1$ & $1,061.4$ & 714.7 & 392.9 \\
\hline 17 & MR-37 & OD & 27.3 & 5.4 & 8.6 & $1,267.8$ & 845.2 & 709.9 & 417.8 \\
\hline 18 & MR-113E & ID & 29.2 & 7.0 & 7.3 & $1,492.1$ & 994.7 & 732.9 & 415.3 \\
\hline 19 & MR-63D & OD & 22.2 & 7.3 & 11.4 & $1,847.5$ & $1,231.7$ & 834.7 & 472.4 \\
\hline 20 & MR-63K & OD & 23.2 & 7.3 & 11.1 & $1,879.9$ & $1,253.3$ & 846.5 & 479.8 \\
\hline 21 & MR-64F & OD & 24.8 & 7.0 & 10.2 & $1,770.7$ & $1,180.5$ & 822.3 & 468.9 \\
\hline 22 & MR-35A & OD & 31.8 & 7.0 & 7.6 & $1,691.8$ & $1,127.8$ & 812.4 & 463.7 \\
\hline 23 & MR-63E & OD & 28.3 & 7.3 & 9.5 & $1,962.6$ & $1,308.4$ & 883.0 & 503.5 \\
\hline 24 & MR-64E & ID & 29.2 & 7.8 & 9.0 & $2,049.8$ & $1,366.6$ & 893.8 & 505.2 \\
\hline 25 & MR-113D & OD & 27.9 & 7.6 & 10.2 & $2,162.8$ & $1,441.9$ & 936.2 & 532.7 \\
\hline 26 & MR-64C & OD & 29.2 & 9.8 & 10.2 & $2,918.8$ & $1,945.9$ & $1,081.8$ & 599.3 \\
\hline 27 & MR-62A & ID & 29.8 & 7.0 & 11.4 & $2,378.0$ & $1,585.4$ & $1,047.6$ & 609.9 \\
\hline 28 & MR-63HJ & OD & 47.0 & 6.0 & 6.0 & $1,692.0$ & $1,128.0$ & 918.0 & 538.5 \\
\hline 29 & MR-62J & ID & 37.5 & 5.7 & 8.9 & $1,902.4$ & $1,268.3$ & 982.7 & 587.4 \\
\hline 30 & MR-113F & OD & 36.2 & 8.6 & 8.9 & $2,770.7$ & $1,847.2$ & $1,108.8$ & 628.4 \\
\hline 31 & MR-63A & OD & 32.4 & 8.9 & 11.0 & $3,172.0$ & $2,114.6$ & $1,197.0$ & 677.6 \\
\hline 32 & MR-62C & ID & 35.6 & 6.4 & 12.1 & $2,756.9$ & $1,837.9$ & $1,244.2$ & 746.7 \\
\hline 33 & MR-105B & OD & 34.3 & 7.9 & 13.2 & $3,576.8$ & $2,384.5$ & $1,385.1$ & 809.0 \\
\hline 34 & MR-113C & ID & 34.3 & 12.1 & 12.7 & $5,270.9$ & $3,513.9$ & $1,593.6$ & 880.1 \\
\hline 35 & MR-62EF & ID & 54.6 & 7.6 & 11.4 & $4,730.5$ & $3,153.7$ & $1,833.1$ & $1,097.9$ \\
\hline
\end{tabular}


Table 2.67 Seam Weld Defects in the Nozzles of the Hope Creek Unit 2 RPV

\begin{tabular}{|r|c|l|c|c||}
\hline No. & NDE & \multicolumn{1}{|c|}{ Defect Type } & Length (cm) & Repair ID \\
\hline 1 & RT & Slag inclusion & 1.3 & MR-96 \\
\hline 2 & RT & Slag inclusion & 1.3 & MR-61D \\
\hline 3 & RT & Slag & 2.5 & MR-102 \\
\hline 4 & RT & Slag inclusion & 2.5 & MR-60A \\
\hline 5 & RT & Slag inclusion & & MR-60C2 \\
\hline 6 & RT & Did not see & 5.1 & MR-73 \\
\hline 7 & RT & Slag & 1.3 & MR-61B \\
\hline 8 & RT & Slag inclusion & 2.5 & MR-90 \\
\hline 9 & RT & Slag and non-fusion & 12.7 & MR-129 \\
\hline 10 & RT & Slag & 1.3 & MR-130 \\
\hline 11 & RT & Did not find & & MR-74 \\
\hline 12 & RT & Porosity and slag & 1.3 & MR-60C1 \\
\hline 13 & RT & Slag inclusion & \multicolumn{2}{|l}{} \\
\hline
\end{tabular}

Table 2.68 Estimated Surface Area and Volume of Seam Weld Repair in the Nozzles of the Hope Creek Unit 2 RPV

\begin{tabular}{|c|c|c|c|c|c|c|c|c|c|}
\hline \multirow[b]{2}{*}{ No. } & \multirow[b]{2}{*}{ Repair ID } & \multirow[b]{2}{*}{$\begin{array}{l}\text { ID/ } \\
\text { OD }\end{array}$} & \multicolumn{3}{|c|}{ Cavity Dimensions } & \multicolumn{2}{|c|}{ Volume } & \multicolumn{2}{|c|}{ Surface Area } \\
\hline & & & $\begin{array}{c}\text { Length } \\
\text { (cm) }\end{array}$ & $\begin{array}{c}\text { Width } \\
\text { (cm) }\end{array}$ & $\begin{array}{c}\text { Depth } \\
\text { (cm) }\end{array}$ & $\begin{array}{c}\text { Bounding } \\
\left(\mathrm{cm}^{3}\right)\end{array}$ & \begin{tabular}{|c|} 
Corrected \\
$\left(\mathrm{cm}^{3}\right)$
\end{tabular} & $\begin{array}{c}\text { Bounding } \\
\left(\mathrm{cm}^{2}\right)\end{array}$ & \begin{tabular}{|c|} 
Corrected \\
$\left(\mathrm{cm}^{2}\right)$
\end{tabular} \\
\hline 1 & MR-96 & OD & 3.5 & 1.0 & 0.6 & 2.1 & 1.4 & 8.9 & 4.9 \\
\hline 2 & MR-61D & OD & 11.4 & 3.2 & 2.5 & 91.2 & 60.8 & 109.5 & 60.9 \\
\hline 3 & MR-102 & OD & 11.4 & 5.1 & 2.9 & 168.6 & 112.4 & 153.8 & 83.0 \\
\hline 4 & MR-60A & OD & 13.3 & 8.9 & 2.2 & 260.4 & 173.6 & 216.1 & 119.7 \\
\hline 5 & MR-60C2 & ID & 16.5 & 7.0 & 5.1 & 589.1 & 392.7 & 355.2 & 192.2 \\
\hline 6 & MR-73 & OD & 20.3 & 5.7 & 4.1 & 474.4 & 316.3 & 328.9 & 182.9 \\
\hline 7 & MR-82 & OD & 22.9 & 6.4 & 6.7 & 982.0 & 654.6 & 539.2 & 302.5 \\
\hline 8 & MR-61B & OD & 29.2 & 8.3 & 7.6 & $1,841.9$ & $1,228.0$ & 812.4 & 453.1 \\
\hline 9 & MR-90 & OD & 29.2 & 6.4 & 8.9 & $1,663.2$ & $1,108.8$ & 820.6 & 475.1 \\
\hline 10 & MR-129 & OD & 34.3 & 4.8 & 7.6 & $1,251.3$ & 834.2 & 759.0 & 456.4 \\
\hline 11 & MR-130 & OD & 34.3 & 7.3 & 9.5 & $2,378.7$ & $1,585.8$ & $1,040.8$ & 601.3 \\
\hline 12 & MR-74 & OD & 30.5 & 10.2 & 11.4 & $3,546.5$ & $2,364.4$ & $1,239.1$ & 688.5 \\
\hline 13 & MR-60C1 & OD & 33.7 & 6.7 & 12.9 & $2,912.7$ & $1,941.8$ & $1,268.1$ & 756.5 \\
\hline
\end{tabular}

Table 2.69 Seam Weld Defects in the Top Head of the River Bend Unit 2 RPV

\begin{tabular}{|c|c|l|c|c||}
\hline \hline No. & NDE & \multicolumn{1}{|c|}{ Defect Type } & $\begin{array}{c}\text { Length } \\
(\mathbf{c m})\end{array}$ & Repair ID \\
\hline 1 & RT & Round slag pockets & 1.3 & MR-81 \\
\hline
\end{tabular}


Table 2.70 Estimated Surface Area and Volume of Seam Weld Repair in the Top Head of the River Bend Unit 2 RPV

\begin{tabular}{|c|c|c|c|c|c|c|c|c|c|}
\hline \multirow[b]{2}{*}{ No. } & \multirow[b]{2}{*}{ Repair ID } & \multirow[b]{2}{*}{$\begin{array}{l}\text { ID/ } \\
\text { OD }\end{array}$} & \multicolumn{3}{|c|}{ Cavity Dimensions } & \multicolumn{2}{|c|}{ Volume } & \multicolumn{2}{|c|}{ Surface Area } \\
\hline & & & $\begin{array}{c}\text { Length } \\
\text { (cm) }\end{array}$ & $\begin{array}{c}\text { Width } \\
\text { (cm) }\end{array}$ & $\begin{array}{c}\text { Depth } \\
\text { (cm) }\end{array}$ & $\begin{array}{c}\text { Bounding } \\
\left(\mathrm{cm}^{3}\right)\end{array}$ & $\begin{array}{c}\text { Corrected } \\
\left(\mathrm{cm}^{3}\right)\end{array}$ & $\begin{array}{c}\text { Bounding } \\
\left(\mathrm{cm}^{2}\right)\end{array}$ & $\begin{array}{c}\text { Corrected } \\
\left(\mathrm{cm}^{2}\right)\end{array}$ \\
\hline 1 & $\mathrm{R}-81$ & OD & 14.9 & 5.1 & 4.9 & 372.4 & 248.2 & 272.0 & 150.1 \\
\hline
\end{tabular}

Table 2.71 Seam Weld Defects in the Shell of the River Bend Unit 2 RPV

\begin{tabular}{||c|c|l|c|c||}
\hline \hline No. & NDE & \multicolumn{1}{|c|}{ Defect Type } & Length (cm) & Repair ID \\
\hline 1 & UT & Not found & & R-33 \\
\hline 2 & RT & Porosity & 2.5 & R-11A \\
\hline 3 & RT & Small cluster of porosity & 1.3 & R-62 \\
\hline 4 & UT & & & R-98B \\
\hline 5 & UT & Not found & & R-96B \\
\hline 6 & UT & 3 pin holes & R-96A \\
\hline 7 & UT (60) & Not found & R-98A \\
\hline \hline
\end{tabular}

Table 2.72 Estimated Surface Area and Volume of Seam Weld Repair in the Shell of the River Bend Unit 2 RPV

\begin{tabular}{|c|c|c|c|c|c|c|c|c|c|}
\hline \multirow[b]{2}{*}{ No. } & \multirow[b]{2}{*}{ Repair ID } & \multirow[b]{2}{*}{$\begin{array}{l}\text { ID/ } \\
\text { OD }\end{array}$} & \multicolumn{3}{|c|}{ Cavity Dimensions } & \multicolumn{2}{|c|}{ Volume } & \multicolumn{2}{|c|}{ " Surface Area } \\
\hline & & & $\begin{array}{l}\text { Length } \\
\text { (cm) }\end{array}$ & $\begin{array}{c}\text { Width } \\
\text { (cm) }\end{array}$ & $\begin{array}{c}\text { Depth } \\
\text { (cm) }\end{array}$ & $\begin{array}{c}\text { Bounding } \\
\left(\mathrm{cm}^{3}\right)\end{array}$ & $\begin{array}{c}\text { Corrected } \\
\left(\mathrm{cm}^{3}\right)\end{array}$ & $\begin{array}{c}\text { Bounding } \\
\left(\mathrm{cm}^{2}\right)\end{array}$ & $\begin{array}{c}\text { Corrected } \\
\left(\mathrm{cm}^{2}\right)\end{array}$ \\
\hline 1 & $\mathrm{R}-33$ & ID & 9.0 & 5.4 & 2.4 & 116.6 & 77.8 & 117.7 & 62.8 \\
\hline 2 & R-11A & OD & 14.6 & 5.1 & 3.3 & 245.7 & 163.8 & 204.5 & 112.0 \\
\hline 3 & R-62 & OD & 14.6 & 6.4 & 5.7 & 532.6 & 355.1 & 332.8 & 180.3 \\
\hline 4 & R-98B & ID & 15.9 & 6.7 & 6.7 & 713.8 & 475.8 & 409.4 & 223.1 \\
\hline 5 & R-96B & ID & 19.1 & 6.0 & 8.3 & 951.2 & 634.1 & 531.3 & 299.6 \\
\hline 6 & R-96A & OD & 21.6 & 6.7 & 12.4 & $1,794.5$ & $1,196.4$ & 846.6 & 487.3 \\
\hline 7 & R-98A & OD & 27.9 & 7.6 & 13.0 & $2,756.5$ & $1,837.7$ & $1,135.0$ & 655.3 \\
\hline
\end{tabular}

Table 2.73 Seam Weld Defects in the Nozzles of the River Bend Unit 2 RPV

\begin{tabular}{||c|c|l|c|c||}
\hline \hline No. & NDE & Defect Type & Length (cm) & Repair ID \\
\hline 1 & RT & Slag line & 3.2 & R-45 \\
\hline 2 & UT & Non fusion & 2.5 & R-34 \\
\hline 3 & RT & Slag line & 4.4 & R-61 \\
\hline
\end{tabular}


Table 2.74 Estimated Surface Area and Volume of Seam Weld Repair in the Nozzles of the River Bend Unit 2 RPV

\begin{tabular}{|c|c|c|c|c|c|c|c|c|c|}
\hline \multirow[b]{2}{*}{ No. } & \multirow[b]{2}{*}{ Repair ID } & \multirow[b]{2}{*}{$\begin{array}{l}\text { ID/ } \\
\text { OD }\end{array}$} & \multicolumn{3}{|c|}{ Cavity Dimensions } & \multicolumn{2}{|c|}{ Volume } & \multicolumn{2}{|c|}{ Surface Area } \\
\hline & & & $\begin{array}{c}\begin{array}{c}\text { Length } \\
\text { (cm) }\end{array} \\
\end{array}$ & $\begin{array}{c}\text { Width } \\
\text { (cm) }\end{array}$ & $\begin{array}{c}\text { Depth } \\
(\mathrm{cm})\end{array}$ & $\begin{array}{c}\text { Bounding } \\
\left(\mathrm{cm}^{3}\right)\end{array}$ & \begin{tabular}{|c|c|}
$\begin{array}{c}\text { Corrected } \\
\left(\mathrm{cm}^{3}\right)\end{array}$ \\
\end{tabular} & $\begin{array}{c}\text { Bounding } \\
\left(\mathrm{cm}^{2}\right)\end{array}$ & $\begin{array}{c}\text { Corrected } \\
\left(\mathrm{cm}^{2}\right) \\
\end{array}$ \\
\hline 1 & R-45 & OD & 11.4 & 5.1 & 1.9 & 110.5 & 73.6 & 120.8 & 66.4 \\
\hline 2 & R-34 & OD & 12.7 & 3.5 & 4.1 & 182.2 & 121.5 & 177.3 & 100.1 \\
\hline 3 & $\mathrm{R}-61$ & ID & 22.9 & 7.6 & 8.6 & $1,496.7$ & 997.8 & 698.6 & 388.6 \\
\hline
\end{tabular}

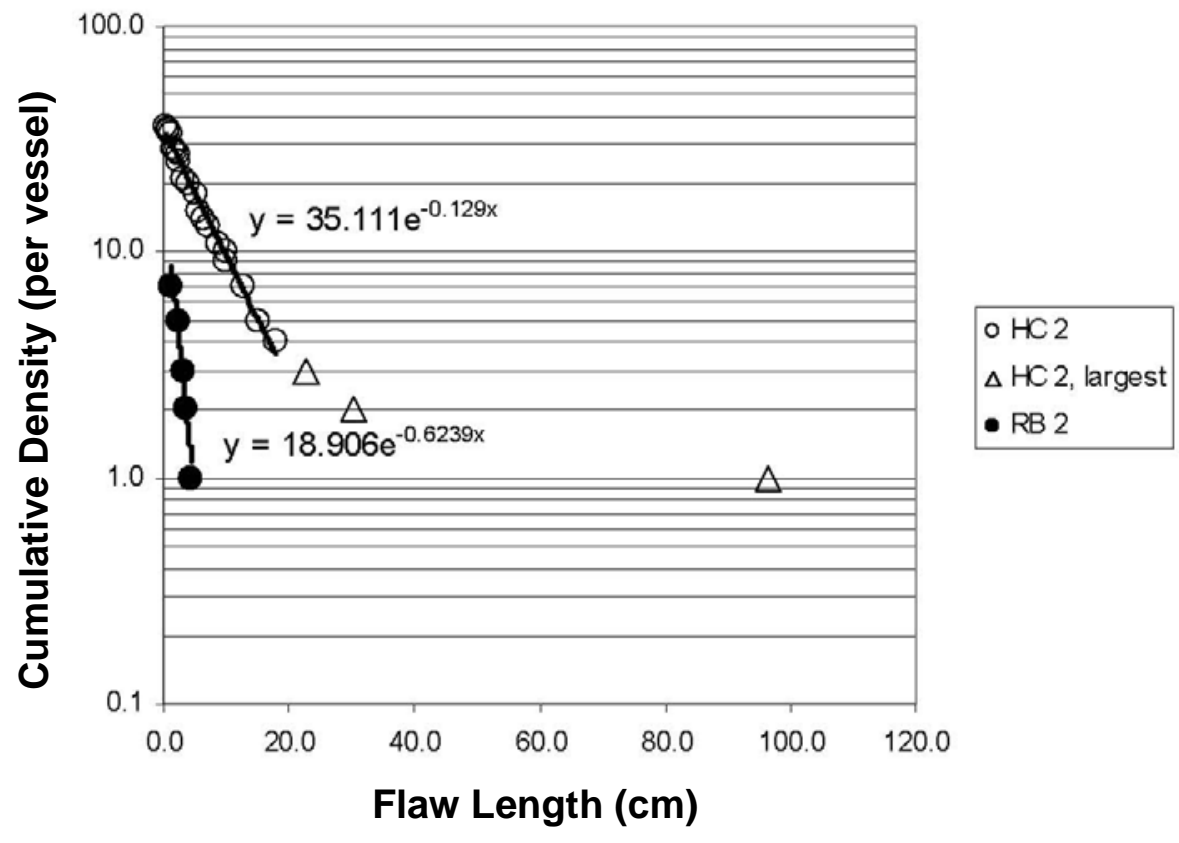

Figure 2.10 Comparison of Defect Length in the Seam Welds of the Hope Creek Unit 2 and River Bend Unit 2 RPVs 


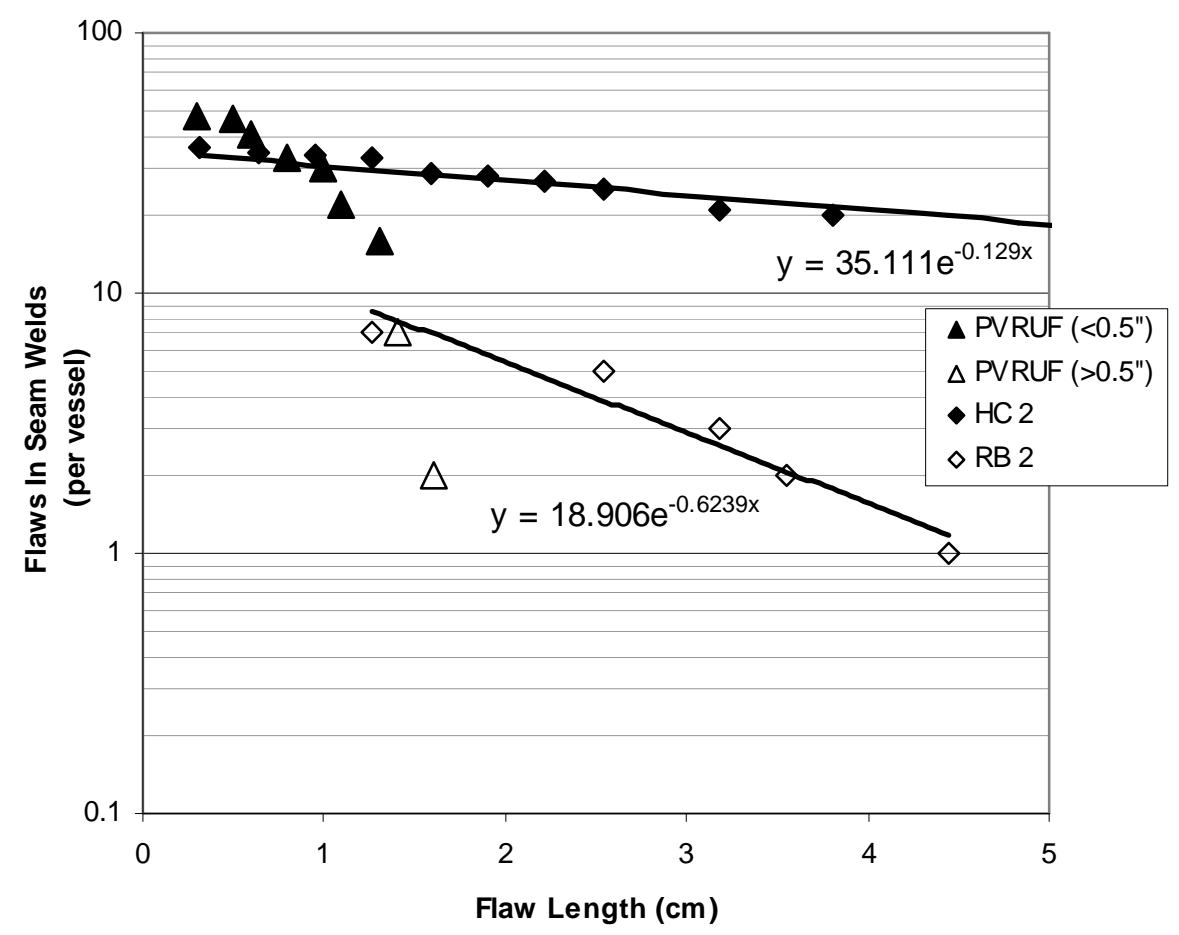

Figure 2.11 Comparison of Flaw Length in the Seam Welds of Three RPVs

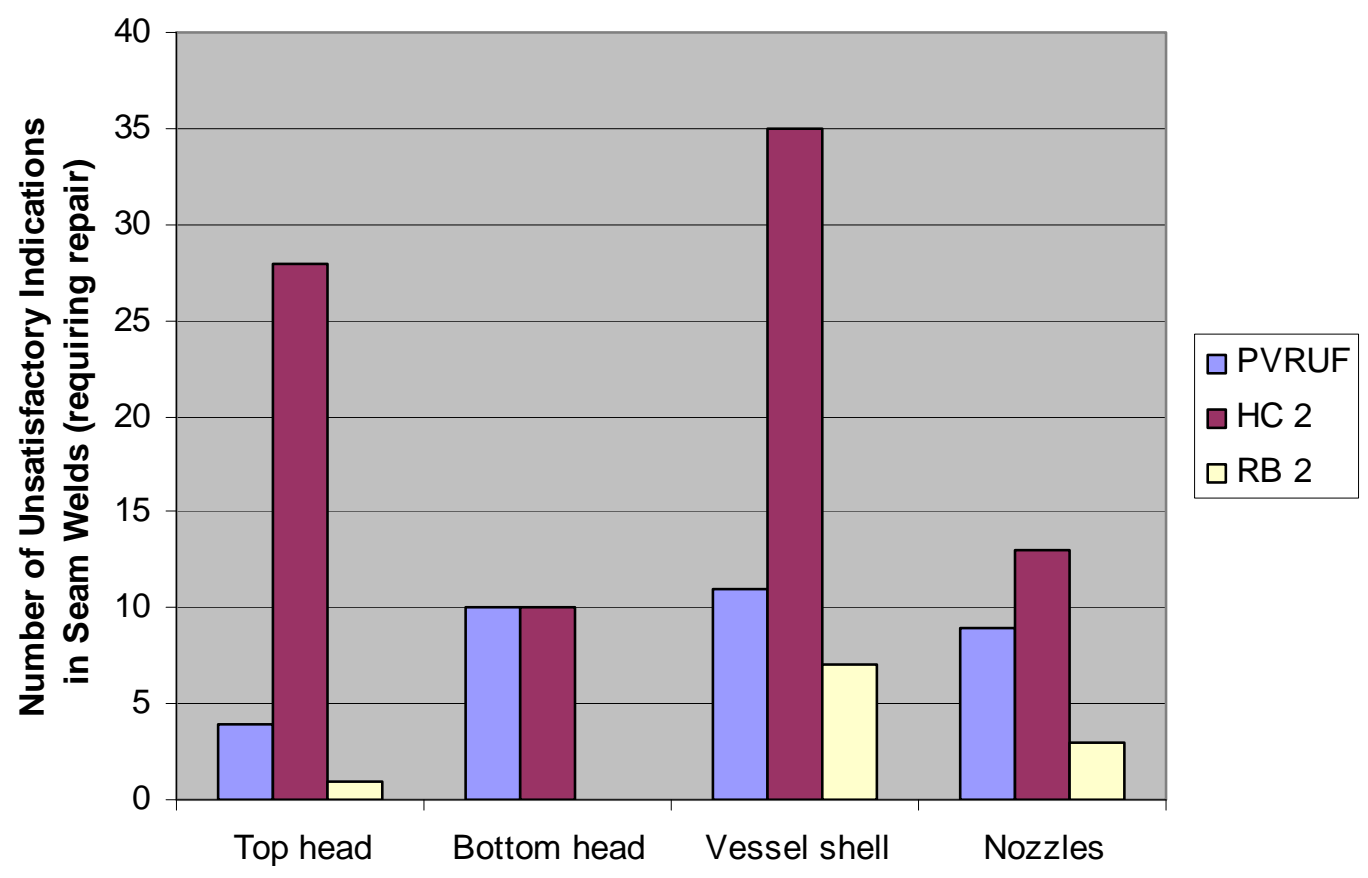

Figure 2.12 Comparison of Estimated Repair Frequency for the Seam Welds in Three RPVs 


\subsection{RPV Miscellaneous Defects and Repairs}

Miscellaneous repairs were made to the primary pressure boundary of the RPVs. Repairs to the weld preparation surfaces, control rod drive nozzles, and J-groove seal welds were documented in the construction records. The data, where available, are provided in this section.

\subsubsection{Weld Preparation Surface Repairs}

Five repairs to the weld preparation surfaces of the Hope Creek Unit 2 RPV were documented in the construction records. MT found base metal plate segregates, and repairs were made by welding. These repairs were not considered major, and no repair traveler was generated. The cavity dimensions were recorded on the MT reports.

Table 2.75 lists defects found on the weld preparation surfaces of the PVRUF RPV. One MT inspection reported unsatisfactory conditions. Defect type and length were not reported.

Table 2.76 shows the indications found and repaired on the weld preparation surfaces of the Hope Creek Unit 2 RPV. Table 2.77 lists the estimated repair surface area and volume of repair cavities and shows the base metal plate that was repaired. The weld preparation surface is identified, and the cavity dimensions are given.

Table 2.75 Unsatisfactory Inspections (Requiring Repair) on the Weld Preparation Surfaces of PVRUF RPV

\begin{tabular}{|c|c|c|c|c|c|}
\hline No. & NDE & $\begin{array}{c}\text { Indication } \\
\text { Type }\end{array}$ & $\begin{array}{c}\text { Length } \\
\text { (cm) }\end{array}$ & $\begin{array}{c}\text { Inspection } \\
\text { ID }\end{array}$ & Job ID \\
\hline 1 & MT & (Not given) & (Not given) & A-114785 & $750104-055$ \\
\hline
\end{tabular}

Table 2.76 Indications Found and Repaired on the Weld Preparation Surfaces of the Hope Creek Unit 2 RPV

\begin{tabular}{|c|c|c|c|c||}
\hline \hline No. & NDE & $\begin{array}{c}\text { Indication } \\
\text { Type }\end{array}$ & $\begin{array}{c}\text { Length } \\
\text { (cm) }\end{array}$ & Repair ID \\
\hline 1 & MT & Segregates & 1.9 & D \\
\hline 2 & MT & Segregates & 2.5 & C \\
\hline 3 & MT & Segregates & 3.8 & A \\
\hline 4 & MT & Segregates & 4.4 & E \\
\hline 5 & MT & Segregates & 9.2 & B \\
\hline
\end{tabular}


Table 2.77 Surface Area and Volume of Repair Cavities on Weld Preparation Surfaces of the Hope Creek Unit 2 RPV

\begin{tabular}{|c|c|c|c|c|c|c|c|c|c|}
\hline \multirow[b]{2}{*}{ No. } & \multirow[b]{2}{*}{$\begin{array}{l}\text { Repair } \\
\text { ID }\end{array}$} & \multirow[b]{2}{*}{ Plate } & \multicolumn{3}{|c|}{ "Cavity Dimensions } & \multicolumn{2}{|c|}{ Volume } & \multicolumn{2}{|c|}{ Surface Area } \\
\hline & & & $\begin{array}{l}\text { Length } \\
\text { (cm) }\end{array}$ & $\begin{array}{c}\text { Width } \\
\text { (cm) }\end{array}$ & $\begin{array}{c}\text { Depth } \\
\text { (cm) }\end{array}$ & $\begin{array}{c}\text { Bounding } \\
\left(\mathrm{cm}^{3}\right)\end{array}$ & $\begin{array}{c}\text { Corrected } \\
\left(\mathrm{cm}^{3}\right)\end{array}$ & $\begin{array}{c}\text { Bounding } \\
\left(\mathrm{cm}^{2}\right)\end{array}$ & $\begin{array}{c}\text { Corrected } \\
\left(\mathrm{cm}^{2}\right)\end{array}$ \\
\hline 1 & $\mathrm{D}$ & Pc 22-2 & 14.6 & 6.4 & 1.3 & 121.5 & 81.0 & 148.0 & 86.2 \\
\hline 2 & $\bar{C}$ & Pc 22-2 & 15.2 & 6.4 & 1.3 & 122.9 & 83.6 & 151.6 & 114.8 \\
\hline 3 & A & Pc 22-2 & 17.8 & 6.4 & 1.6 & 182.3 & 121.5 & 191.4 & 110.2 \\
\hline 4 & $\mathrm{E}$ & Pc 22-2 & 19.1 & 6.4 & 1.9 & 232.3 & 154.8 & 219.1 & 124.8 \\
\hline 5 & B & Рc 22-2 & 27.9 & 6.4 & 1.9 & 339.3 & 226.2 & 308.9 & 179.7 \\
\hline
\end{tabular}

\subsubsection{J-Weld Defects and Repairs}

Six repairs to the control rod drive (CRD) J-welds of the Hope Creek Unit 2 RPV were documented in the construction records, as was one repair to the CRD J-welds of the River Bend Unit 2 RPV. The defects were due to welding (slag) and material handling errors. The welding defects were detected by PT, and material handling defects were visually apparent.

Table 2.78 lists defects in the control rod drive mechanism J-welds of the PVRUF RPV.

Table 2.79 gives the welding and handling defects in the J-welds of the Hope Creek 2 RPV, showing defect type and the NDE method that found it. The MR ID from the construction records is given. Table 2.80 lists the estimated surface area and volume of repair cavities by J-weld number, and then lists the cavity dimensions for the repair. The River Bend 2 RPV had one defect in the J-welds as shown in Tables 2.81 and 2.82 .

Table 2.78 Unsatisfactory Inspections (Requiring Repair) in the Control Rod Drive Mechanism J-Welds of the PVRUF RPV

\begin{tabular}{|c|c|c|c|c|c||}
\hline No. & NDE & $\begin{array}{c}\text { Indication } \\
\text { Type }\end{array}$ & $\begin{array}{c}\text { Length } \\
\text { (cm) }\end{array}$ & Inspection ID & Job ID \\
\hline 1 & PT & (Not given) & (Not given) & A-006033 & $750101-030$ \\
\hline 2 & PT & (Not given) & (Not given) & A-013593 & $750101-075$ \\
\hline 3 & PT & (Not given) & (Not given) & A-018775 & RN 3122-80 \\
\hline 4 & PT & (Not given) & (Not given) & A-015629 & RN 3122-80 \\
\hline
\end{tabular}


Table 2.79 Welding and Handling Defects in the Control Rod Drive J-Welds of the Hope Creek Unit 2 RPV

\begin{tabular}{||c|c|l|c|c||}
\hline \hline No. & NDE & \multicolumn{1}{|c|}{ Indication Type } & Length (cm) & Repair ID \\
\hline 1 & PT & Slag & (Not given) & MR-66C \\
\hline 2 & (Visual) & Arc strike & (Not given) & MR-126 \\
\hline 3 & PT & Slag & (Not given) & MR-66D \\
\hline 4 & PT & Slag & (Not given) & MR-66A \\
\hline 5 & PT & Slag & (Not given) & MR-66B \\
\hline 6 & (Visual) & $\begin{array}{l}\text { Machine malfunction } \\
\text { during shaping weld prep }\end{array}$ & MR-53 \\
\hline
\end{tabular}

Table 2.80 Estimated Surface Area and Volume of Repair Cavities in the Control Rod Drive JWelds of the Hope Creek Unit 2 RPV

\begin{tabular}{|c|c|c|c|c|c|c|c|c|}
\hline \multirow[b]{2}{*}{ No. } & \multirow[b]{2}{*}{ Repair ID } & \multicolumn{3}{|c|}{ Cavity Dimensions } & \multicolumn{2}{|c|}{ Volume } & \multicolumn{2}{|c|}{ Surface Area } \\
\hline & & $\begin{array}{c}\text { Length } \\
\text { (cm) }\end{array}$ & $\begin{array}{l}\text { Width } \\
\text { (cm) }\end{array}$ & $\begin{array}{l}\text { Depth } \\
\text { (cm) }\end{array}$ & $\begin{array}{c}\text { Bounding } \\
\left(\mathrm{cm}^{3}\right)\end{array}$ & $\begin{array}{c}\text { Corrected } \\
\left(\mathrm{cm}^{3}\right)\end{array}$ & $\begin{array}{c}\text { Bounding } \\
\left(\mathrm{cm}^{2}\right)\end{array}$ & $\begin{array}{c}\text { Corrected } \\
\left(\mathrm{cm}^{2}\right)\end{array}$ \\
\hline 1 & MR-66C & 2.5 & 0.6 & 0.4 & 0.6 & 0.4 & 4.0 & 2.2 \\
\hline 2 & MR-126 & 3.2 & 1.3 & 0.2 & 0.8 & 0.6 & 6.0 & 3.6 \\
\hline 3 & MR-66D & $\overline{4.4}$ & 1.0 & 0.6 & 2.6 & 1.8 & 10.9 & 6.1 \\
\hline 4 & $\overline{M R-66 A}$ & 3.8 & 2.5 & 0.3 & 2.9 & 1.9 & 13.3 & 8.1 \\
\hline 5 & MR-66B & 12.7 & 1.3 & 0.5 & 8.3 & 5.5 & 30.5 & 18.2 \\
\hline
\end{tabular}

Table 2.81 Welding Defects in the Control Rod Drive J-Welds of the River Bend Unit 2 RPV

\begin{tabular}{||c|c|c|c|c||}
\hline No. & NDE & Indication Type & Length (cm) & Repair ID \\
\hline 1 & PT & Slag & (Not given) & MR-78 \\
\hline
\end{tabular}

Table 2.82 Surface Area and Volume of Repair Cavities in the Control Rod Drive J-Welds of the River Bend Unit 2 RPV

\begin{tabular}{|c|c|c|c|c|c|c|c|c|}
\hline \multirow[b]{2}{*}{ No. } & \multirow[b]{2}{*}{ Repair ID } & \multicolumn{3}{|c|}{ "Cavity Dimensions } & \multicolumn{2}{|c|}{ Volume } & \multicolumn{2}{|c|}{ Surface Area } \\
\hline & & $\begin{array}{c}\text { Length } \\
(\mathrm{cm})\end{array}$ & $\begin{array}{l}\text { Width } \\
\text { (cm) }\end{array}$ & $\begin{array}{c}\text { Depth } \\
\text { (cm) }\end{array}$ & $\begin{array}{c}\text { Bounding } \\
\left(\mathrm{cm}^{3}\right)\end{array}$ & $\begin{array}{c}\text { Corrected } \\
\left(\mathrm{cm}^{3}\right)\end{array}$ & $\begin{array}{c}\text { Bounding } \\
\left(\mathrm{cm}^{2}\right)\end{array}$ & $\begin{array}{c}\text { Corrected } \\
\left(\mathrm{cm}^{2}\right)\end{array}$ \\
\hline 1 & MR-78 & 4.1 & 1.3 & 0.6 & 3.2 & 2.1 & 11.8 & 6.6 \\
\hline
\end{tabular}




\subsubsection{Control Rod Drive Nozzle Defects and Repairs}

Seven repairs to the control rod drive nozzles of the Hope Creek Unit 2 RPV were documented in the construction records. The defects were due to material handling errors; they were not detected by NDE but instead were visually apparent.

Table 2.83 lists these handling defects. These defects were on the outside wetted end of the CRD nozzles. Table 2.84 gives the cavity dimensions, surface area, and volume.

Table 2.83 Handling Defects in the Control Rod Drive Nozzles of the Hope Creek Unit 2 RPV

\begin{tabular}{||c|c|l|c|c||}
\hline No. & NDE & \multicolumn{1}{|c|}{$\begin{array}{c}\text { Indication } \\
\text { Type }\end{array}$} & $\begin{array}{c}\text { Length } \\
\text { (cm) }\end{array}$ & Repair ID \\
\hline 1 & (Visual) & Dent & (Not given) & MR-160E \\
\hline 2 & (Visual) & Arc strike & (Not given) & MR-160B \\
\hline 3 & (Visual) & Dent & (Not given) & MR-160F \\
\hline 4 & (Visual) & Dent & (Not given) & MR-160G \\
\hline 5 & (Visual) & Arc strike & (Not given) & MR-160A \\
\hline 6 & (Visual) & Arc strike & (Not given) & MR-160C \\
\hline 7 & (Visual) & Arc strike & (Not given) & MR-160D \\
\hline
\end{tabular}

Table 2.84 Surface Area and Volume of Repair Cavities in the Control Rod Drive Nozzles of Hope Creek 2 RPV

\begin{tabular}{|c|c|c|c|c|c|c|c|c|}
\hline \multirow[b]{2}{*}{ No. } & \multirow[b]{2}{*}{ Repair ID } & \multicolumn{3}{|c|}{ Cavity Dimensions } & \multicolumn{2}{|c|}{ Volume } & \multicolumn{2}{|c|}{ Surface Area } \\
\hline & & $\begin{array}{c}\text { Length } \\
\text { (cm) }\end{array}$ & $\begin{array}{l}\text { Width } \\
\text { (cm) }\end{array}$ & $\begin{array}{c}\text { Depth } \\
\text { (cm) }\end{array}$ & $\begin{array}{c}\text { Bounding } \\
\left(\mathrm{cm}^{3}\right)\end{array}$ & $\begin{array}{c}\text { Corrected } \\
\left(\mathrm{cm}^{3}\right)\end{array}$ & $\begin{array}{c}\text { Bounding } \\
\left(\mathrm{cm}^{2}\right)\end{array}$ & $\begin{array}{c}\text { Corrected } \\
\left(\mathrm{cm}^{2}\right)\end{array}$ \\
\hline 1 & MR-160E & 0.64 & 0.64 & 0.16 & 0.07 & 0.04 & 0.82 & 0.44 \\
\hline 2 & MR-160B & 1.59 & 0.32 & 0.16 & 0.08 & 0.05 & 1.12 & 0.64 \\
\hline 3 & MR-160F & 0.64 & 0.95 & 0.16 & 0.10 & 0.06 & 1.12 & 0.62 \\
\hline 4 & MR-160G & 1.91 & 0.32 & 0.16 & 0.10 & 0.07 & 1.32 & 0.76 \\
\hline 5 & MR-160A & 0.95 & 0.95 & 0.16 & 0.14 & 0.10 & 1.51 & 0.85 \\
\hline 6 & MR-160C & 0.95 & 0.95 & 0.16 & 0.14 & 0.10 & 1.51 & 0.85 \\
\hline 7 & MR-160D & 1.91 & 0.64 & 0.95 & 1.16 & 0.77 & 6.07 & 3.42 \\
\hline
\end{tabular}

\subsection{Pipe Weld Repairs}

Table 2.85 lists the dimensions of the repairs in the dissimilar metal weld specimens. Table 2.86 shows the volume and surface area of the repairs. 
Table 2.85 Dimensions of Repairs in Dissimilar Metal Weld Specimens

\begin{tabular}{|l|c|c|c|}
\hline & $\begin{array}{c}\text { Through-Wall } \\
(\mathbf{c m})\end{array}$ & $\begin{array}{c}\text { Axial Dimension } \\
(\mathbf{c m})\end{array}$ & $\begin{array}{c}\text { Circumferential } \\
(\mathbf{c m})\end{array}$ \\
\hline Repair 12.1 & 2.7 & 2.5 & 4.2 \\
\hline Repair 12.2 & 2.8 & 3.7 & 6.5 \\
\hline Repair 12.3 & 3.8 & 4.1 & 13.2 \\
\hline
\end{tabular}

Table 2.86 Volume and Area of Repairs in Dissimilar Metal Weld Specimens

\begin{tabular}{||l|c|c||}
\hline \hline & $\begin{array}{c}\text { Repair Volume } \\
\left(\mathbf{c m}^{\mathbf{3}}\right)\end{array}$ & $\begin{array}{c}\text { Repair Area } \\
\mathbf{( c m}^{\mathbf{2}} \mathbf{)}\end{array}$ \\
\hline Repair 12.1 & 16 & 17 \\
\hline Repair 12.2 & 38 & 27 \\
\hline Repair 12.3 & 114 & 74 \\
\hline Total & 168 & 118 \\
\hline
\end{tabular}

\subsection{Summary of Repair Records}

From the construction records, it is possible to extract the number of defects requiring repair. Figure 2.13 provides data by product form—cladding, base metal, and seam welds. Material handling is also included in the analysis. Material handling defects that required repair were typically caused by damage during temporary attachment removal. The construction records for three vessels-PVRUF, Hope Creek Unit 2, and River Bend Unit 2-were analyzed to obtain the information provided in Figure 2.13. The data show that vessel-to-vessel variation in the number of defects requiring repair can be as much as a factor of 10 .

Additional summary statistics are provided in Tables 2.87, 2.88, and 2.89. These tables show the frequency of repair in the various product forms. Repairs that originated in the removal of temporary fitup fixtures are summarized in the handling category. Table 2.87 shows the repairs made from the inside surface of the vessels. These data are taken from the earlier tables in this section. Table 2.88 shows the frequency of repair from the outside surface. In a few cases, the construction records do not report which surface was used to make the repair. Table 2.89 shows these repairs. 


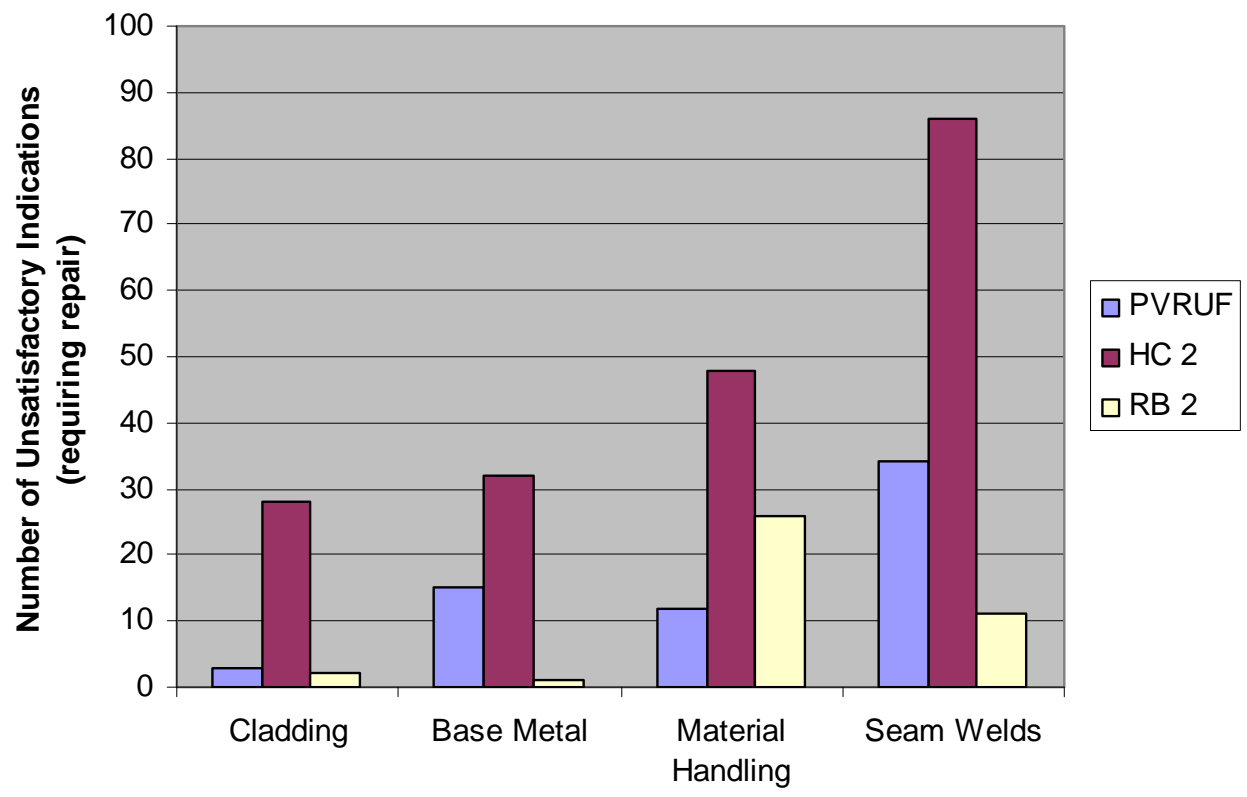

Figure 2.13 Summary of Repair Frequency for Three Reactor Pressure Vessels

Table 2.87 Frequency of Repair from the Inside Surface of Three Reactor Pressure Vessels. The miscellaneous category includes repairs to the CRDM penetration seal welds.

\begin{tabular}{|l|c|c|c|c|c||}
\hline & Cladding & Base metal & Handling & Seams & Misc. \\
\hline HC 2 & 28 & 16 & 4 & 35 & 6 \\
\hline RB 2 & 3 & 1 & 7 & 4 & 1 \\
\hline PVRUF & 3 & & & 18 & 4 \\
\hline
\end{tabular}

Table 2.88 Frequency of Repair from the Outside Surface of Three Reactor Pressure Vessels

\begin{tabular}{|l|c|c|c|}
\hline & Base Metal & Handling & Seams \\
\hline HC 2 & 16 & 36 & 51 \\
\hline RB 2 & & 19 & 7 \\
\hline PVRUF & 11 & & 14 \\
\hline
\end{tabular}

Table 2.89 Frequency of Repair where the Repair Surface was Not Specified in Three Reactor Pressure Vessels. In a few cases, the construction records did not document the repair surface.

\begin{tabular}{|l|c|c|c|}
\hline & Base metal & Handling & Seams \\
\hline HC 2 & & 8 & \\
\hline RB 2 & & & \\
\hline PVRUF & 4 & 12 & 2 \\
\hline
\end{tabular}




\subsection{Inspection of Weld Segments}

Materials from four different reactor pressure vessels and a collection of pipe welds were selected for study. The major component manufacturers and the major reactor designs were considered in the selection. Table 3.1 gives the amount of weld metal and component vintage examined in each of the categories. Table 3.2 lists the methods used to fabricate the welds in the reactor pressure vessels studied in this report. Descriptions of the source of the welds are provided throughout this section.

The inspection of the welds in the PNNL specimens was conducted from a cut and machined surface. This section briefly reviews the measurements used to detect the repairs and form the initial, unvalidated flaw density and distribution within them. Then the sectioning of the weld segment to remove the repair metal is shown.

Figure 3.1 shows a Hope Creek Unit 2 RPV specimen in the PNNL NDE Laboratory for ultrasonic inspection from a cut and machined surface. The surface was smoothed to better than 1.6 microns RMS to enable optimized, high quality UT inspections. The PNNL staff member is adjusting the ultrasonic couplant system, which used heavy mineral oil in this case. The ultrasonic transducer was a 5-MHz contact probe. The Hope Creek Unit 2 RPV specimen shown is a base metal piece. Weld metal specimens can be seen in the left portion of Figure 3.1.

Weld-normal ultrasonic inspections detected the repairs in the specimens. Figure 3.2 shows the detection and location of an undocumented repair in Shoreham Specimen C120E. The shape of the cavity is evidenced by ultrasonic reflections from small flaws on the fusion zone of the repair with the surrounding material.

Table 3.1 Reactor Material Selected for Study

\begin{tabular}{|c|c|c|c|c|c|}
\hline Name & Manufacturer & $\begin{array}{c}\text { Reactor } \\
\text { Type }\end{array}$ & Component & $\begin{array}{l}\begin{array}{l}\text { Length of Weld } \\
\text { (m [ft }])\end{array}\end{array}$ & $\begin{array}{c}\text { Years of } \\
\text { Construction }\end{array}$ \\
\hline Shoreham & $C E^{(a)}$ & BWR & Vessel & $24(79)$ & 1968-1974 \\
\hline Hope Creek Unit 2 & CB\&I ${ }^{(\mathrm{b})}$ & BWR & Vessel & $3(10)$ & 1971-1975 \\
\hline River Bend Unit 2 & CB\&I & BWR & Vessel & $15(50)$ & 1974-1978 \\
\hline PVRUF & $\mathrm{CE}$ & PWR & Vessel & $20(67)$ & 1976-1981 \\
\hline Battelle Archive & $\mathrm{CE}$ & PWR & Piping & $8(25)$ & 1975-1977 \\
\hline
\end{tabular}

Table 3.2 Method Used to Fabricate Welds

\begin{tabular}{||l|l||}
\hline \multicolumn{1}{|c|}{ Weld Type } & \multicolumn{1}{c||}{ Weld Metal } \\
\hline Axial seam & Submerged metal arc \\
\hline Girth seam & Submerged metal arc with shielded metal arc for back gouge restoration \\
\hline Repair to seam & Shielded metal arc \\
\hline
\end{tabular}


Figure 3.3 shows some of the sectioning of repair metal from a Hope Creek Unit 2 specimen. The repairs were found in the images produced using the Synthetic Aperture Focusing Technique for Ultrasonic Testing (SAFT-UT) because of reflections from the small welding flaws in the repairs. Enough small flaws are present in the fusion zone of the repair metal with the surrounding material to permit the mapping of the cavity surface. Once this is done, the sectioning of the repair metal can take place for the validation measurements of the flaws. Figure 3.4 shows an example of validation using film radiography of a repair flaw in PVRUF. Information on PNNL's validation methodology can be found in Doctor and Schuster (2001).

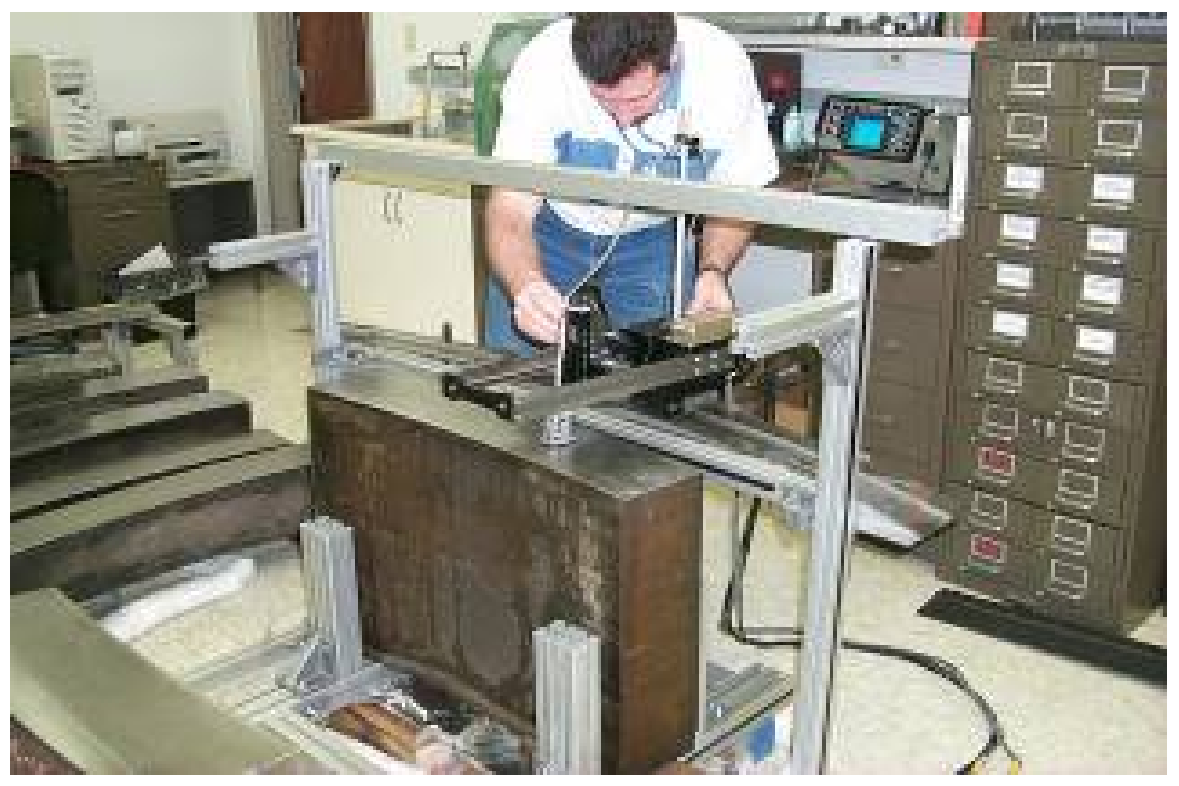

Figure 3.1 Hope Creek Unit 2 Base Metal Specimen in the NDE Laboratory for Ultrasonic Inspection Using Cut and Machined Surface 


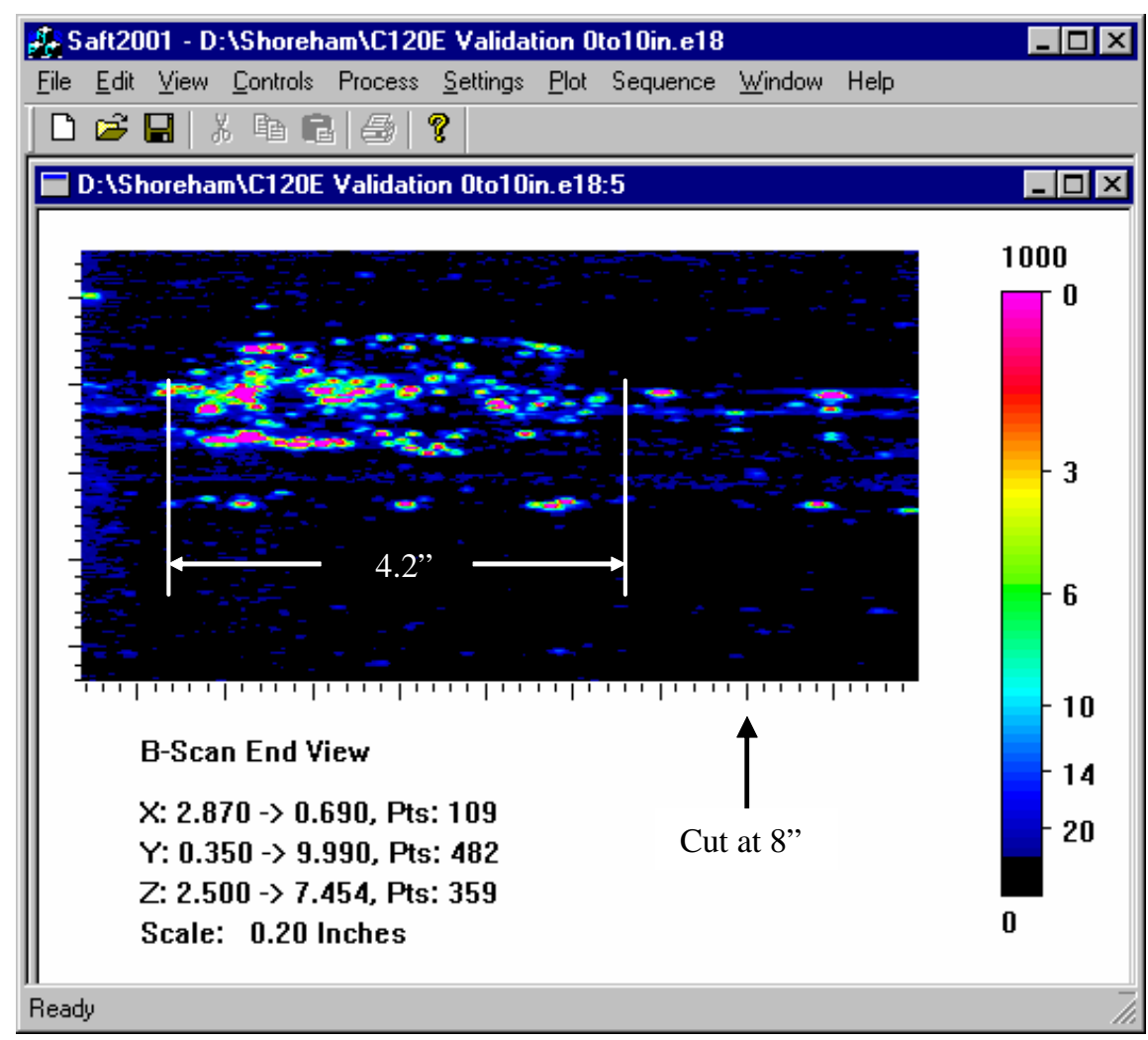

Figure 3.2 Location of an Undocumented Repair in Shoreham Specimen C120E. The units in this figure are shown in inches because the SAFT-UT system is programmed to do so. To convert to centimeters, multiply by 2.54 .

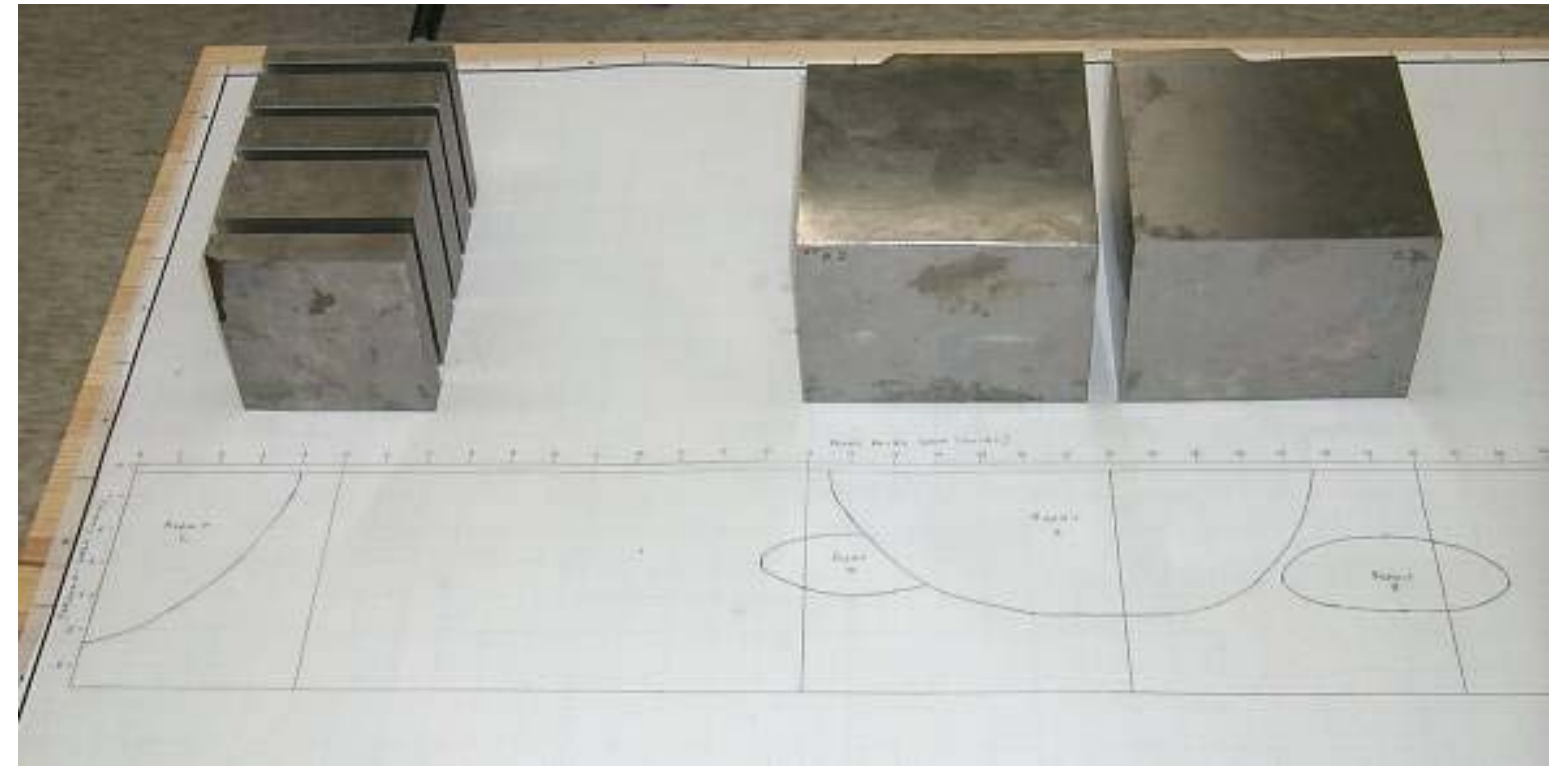

Figure 3.3 Sectioning of Repair Metal from Hope Creek Unit 2 


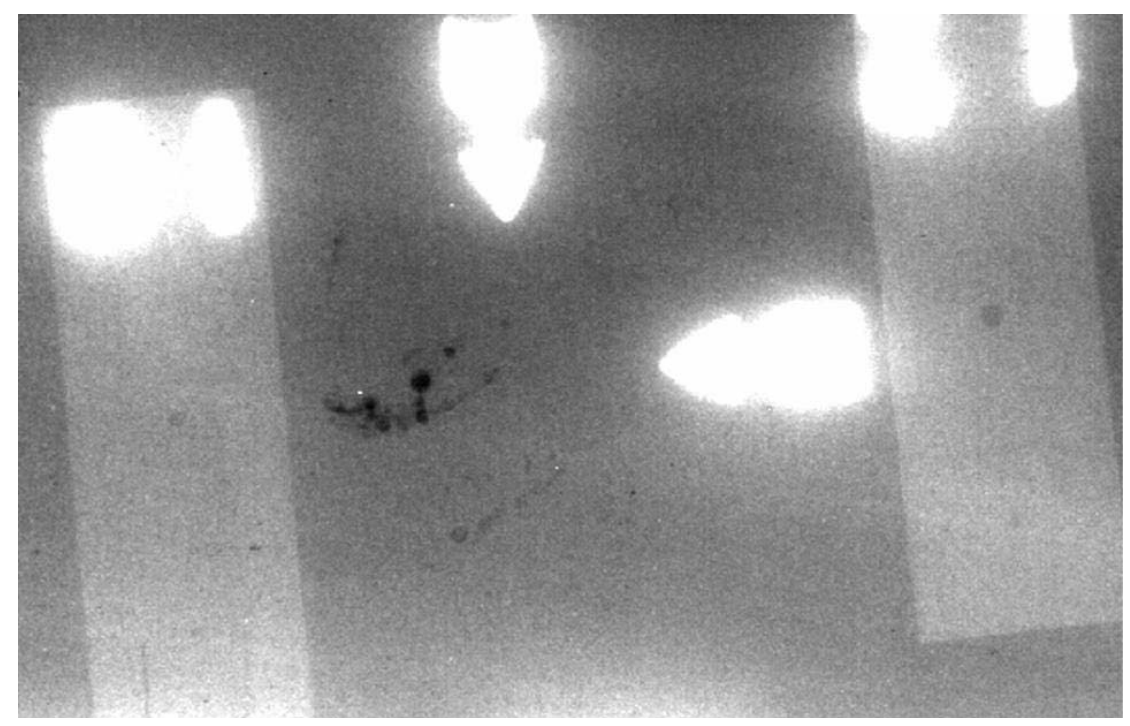

Figure 3.4 Image of Repair Flaw Using Film Radiography

\subsection{Shoreham Reactor Pressure Vessel Weldments}

The Shoreham vessel was assembled by Combustion Engineering in the years 1968-1974. The vessel was installed at the Shoreham Nuclear Power Station, and the plant was made fully operational but did not produce electricity. When the plant was decommissioned, Baltimore Gas \& Electric Company (BGE) purchased portions of the Shoreham reactor vessel, specifically the upper $5 \mathrm{~m}$ of the vessel plus portions of the top and bottom heads. This material includes the vessel flange, the upper shell course containing the steam outlet nozzles, and a portion of the upper-intermediate shell course. Figure 3.5 shows a vessel roll-out drawing with the identification of the weldments selected for study.

The Shoreham vessel was constructed of four shell courses, and each shell course was constructed of three sections of formed plate. The seam weld repairs and the density and distribution of fabrication flaws in these repairs are the subjects of this report. A middle section of material contains the four steam outlet nozzles and portions of the axial welds of the upper shell course identified as 1-308A, B, and C. Each of these three weld portions is $2.1 \mathrm{~m}$ long and was shipped to PNNL. The weld 1-308C is between a pair of nozzles and was not removed for study or inspected. The weld portions 1-308A and B were removed for study. The lower portion of material contains girth weld 4-308A that joins the upper shell course with the upper-intermediate shell course. It also contains portions of axial welds 1-308A, B, C, D, E, and F.

The work on the Shoreham material is part of a joint effort with the Electric Power Research Institute (EPRI) and BGE to evaluate the nature of fabrication flaws in the Shoreham reactor pressure vessel (Rosinski et al. 1998). PNNL's work on extracting weldment specimens from the Shoreham vessel material can be seen in Figure 3.6, where the specimens are shown with the inspection surfaces prepared. Additional information can be found in Schuster et al. (1999). That report documents the results of the nondestructive examination of vessel material removed from the canceled Shoreham Nuclear Power Station. It gives the number and characteristics of the flaw indications detected and sized in the nondestructive examination. PNNL's approach to the research is given. The performance of the SAFT-UT is reported with a complete list of inspection results. 


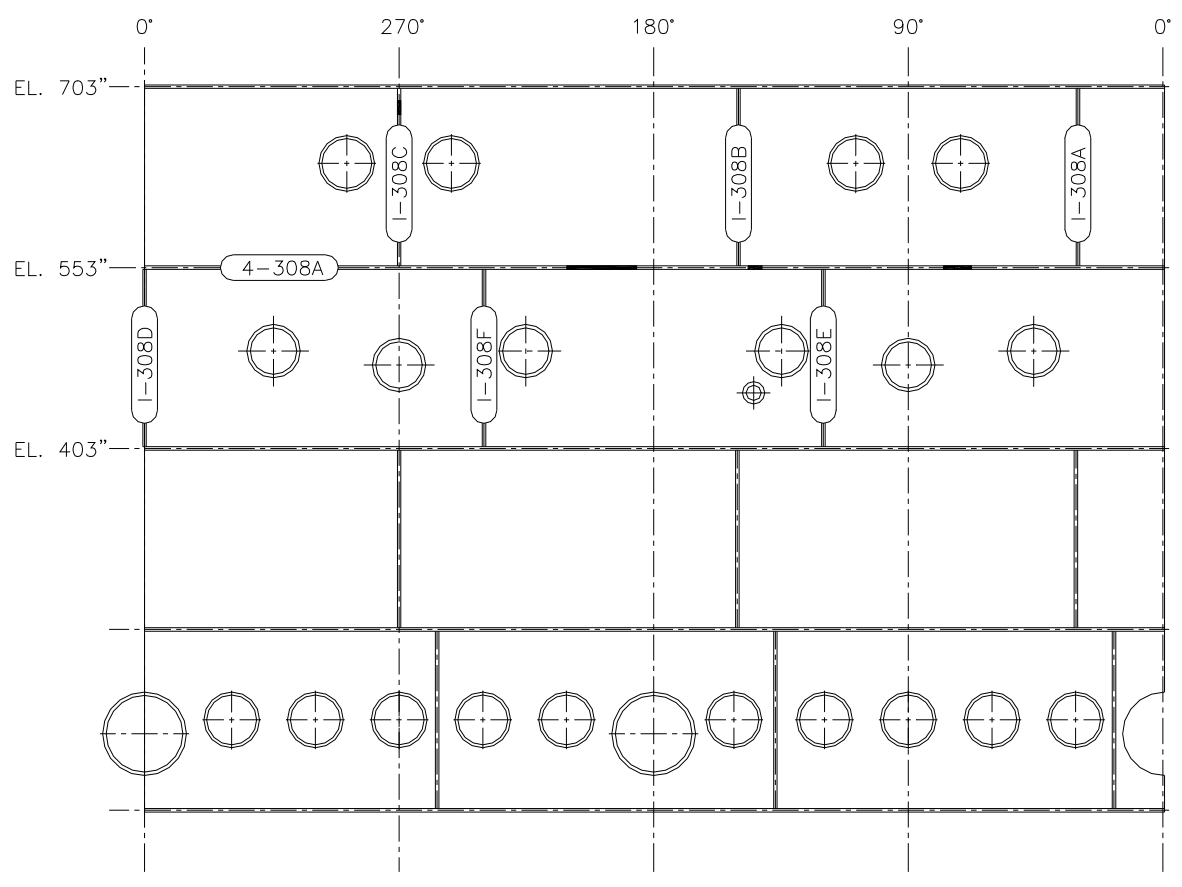

Figure 3.5 Schematic Representation of Seam Welds in Four Shell Courses of the Shoreham Vessel with the Identification Numbers of the Welds in Material Studied

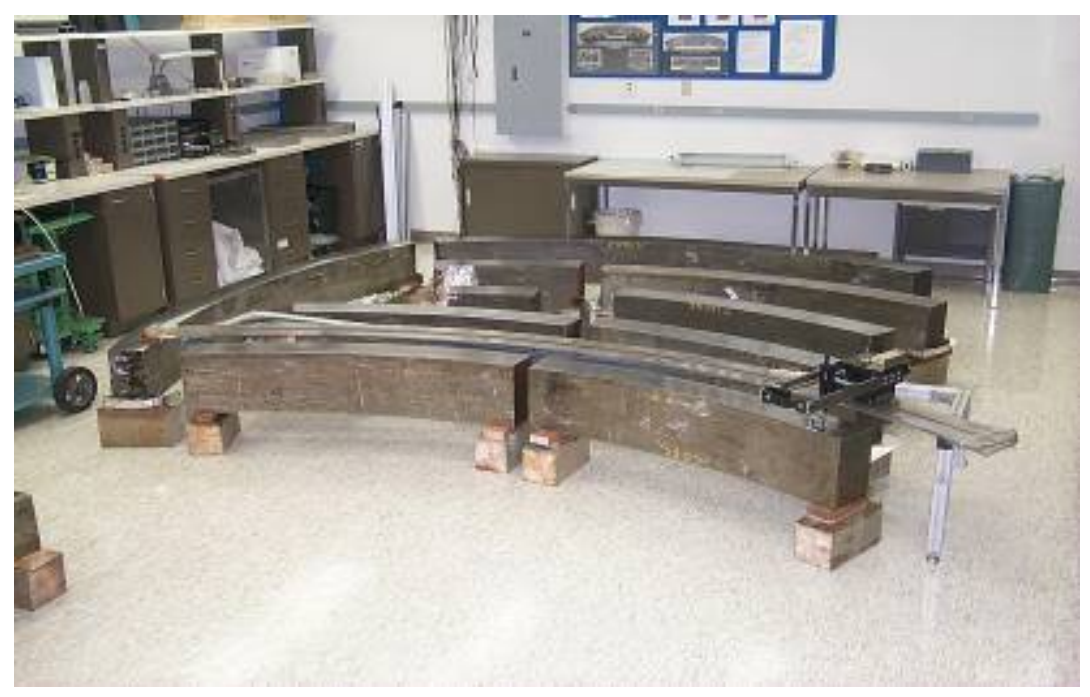

Figure 3.6 Shoreham Specimens in the PNNL NDE Laboratory, Prepared for Weld-Normal Inspection 


\subsection{PVRUF Reactor Pressure Vessel}

The PVRUF pressure vessel was assembled by Combustion Engineering in the years 1976 through 1981 for a nuclear power plant that was cancelled. The pressure vessel was $4.39 \mathrm{~m}$ in diameter and $13.34 \mathrm{~m}$ high and made of A533B material. The wall thickness varies from one region to the next, but within $25 \mathrm{~cm}$ of the beltline weld it was $22 \mathrm{~cm}$ thick. Figure 3.7 shows the PVRUF vessel, located at Oak Ridge National Laboratory, before disassembly.

Nondestructive evaluation of fabrication flaw indications obtained from ultrasonic, volumetric inspections made from the PVRUF vessel's inside, cladded surface are described in Doctor et al. (1999) and Schuster et al. (1998). The SAFT-UT field system was used to inspect all of the beltline (circumferential) weld of the PVRUF vessel and approximately half of the circumferential weld of the intermediate to upper shell course for a total of $20 \mathrm{~m}$ of inspected weld. Schuster et al. (1998) include a discussion of those flaw characteristics that were predicted by fracture mechanics calculations to be most important for vessel integrity. Design and fabrication information on RPVs is presented especially on the subclass of vessels used in PWRs, along with the specifications for the PVRUF vessel. That report discusses the most significant indications found by the inspections through the cladding and documents their important features. The distributions of the indications in those categories important for vessel integrity were presented, along with a methodology for fitting a parametric density function to the distribution of indications detected in the NDE measurements.

The research reported in Schuster et al. (2000) describes laboratory measurements on material removed from the PVRUF vessel. That work was performed to validate the presence and characteristics of the fabrication flaw density and distribution. The report describes the methodology used by PNNL researchers to produce validated flaw densities: weld-normal ultrasonic testing, radiography of 25-mmthick plates, and metallography of $25-\mathrm{mm}$ cubes. The report shows the data obtained by the validation research and describes the validated flaw density and distribution that were obtained from the data.

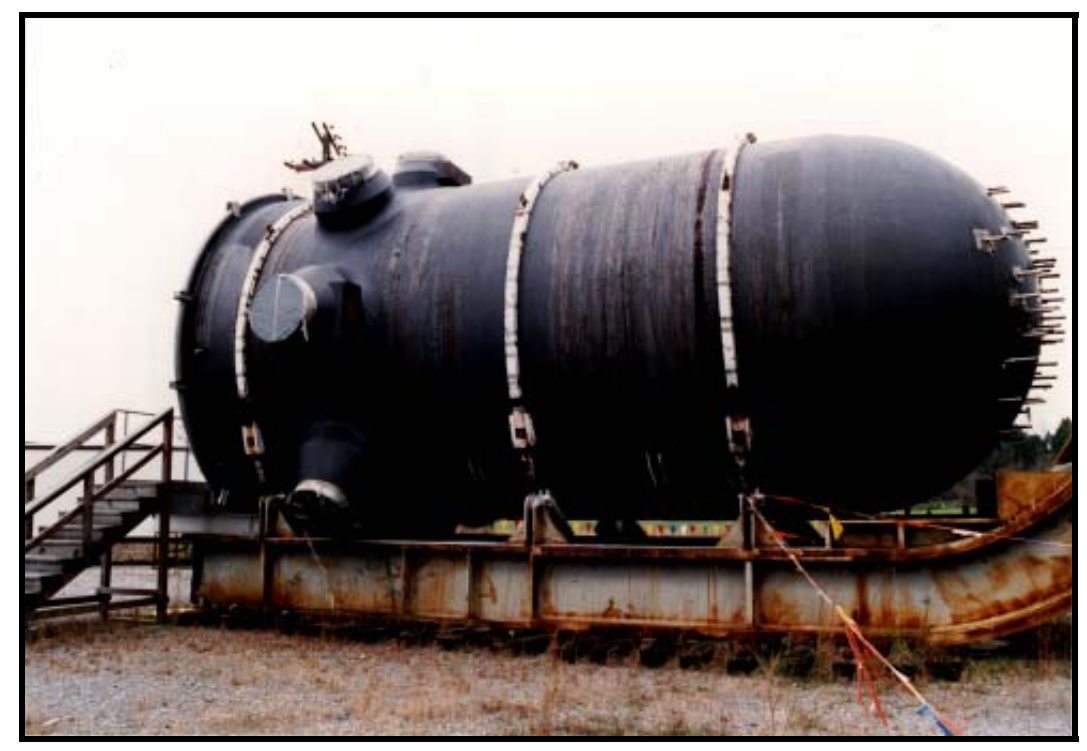

Figure 3.7 PVRUF Reactor Pressure Vessel at Oak Ridge National Laboratory 


\subsection{Hope Creek Unit 2 Reactor Pressure Vessel Weldments}

Material from the Hope Creek Unit 2 RPV 1 is shown in Figure 3.8 as it was received from Hope Creek Unit 2, a BWR. The base metal is A533B bent plate, $15 \mathrm{~cm}$ thick. The locations of the welds were indicated on the outside of the specimen by triple punch marks and numbers used in the radiography performed during construction. The specimen contained a circumferential seam weld and an axial seam weld. The inspection of the welds in the PNNL specimen from the Hope Creek Unit 2 RPV was conducted from a cut and machined surface. These measurements were used to detect the repairs and form the initial, unvalidated flaw density and distribution within them.

After the cut and machined surfaces were prepared, the Hope Creek Unit 2 RPV specimen was taken to the NDE Laboratory for ultrasonic inspection. PNNL staff used a 5-MHz contact probe for the ultrasound and heavy mineral oil as a couplant. SAFT-UT images of the weld regions provided sensitive measurement of the welds and surrounding base metal. A review of recent advances in SAFT-UT and its effectiveness in characterizing RPV welds can be found in Schuster et al. (2004).

The cut and machined surfaces allowed for weld-normal inspections and detected five repairs in this Hope Creek Unit 2 RPV material. Two of the repairs were made to an axial seam weld; three of the repairs were made to the weld preparation surface of one of the base metal plates. The shape of the repair cavities was evidenced by ultrasonic reflections from small flaws on the fusion zone of the repair metal with the surrounding material. Enough small flaws were present in the fusion zone of the repair metal with the surrounding material to permit the mapping of the cavity surface. Once the mapping of repair metal was done, the sectioning of the repair metal could take place for the validation measurements of the flaws.

Table 3.3 lists the material identification numbers from three base metal plates in the Hope Creek Unit 2 RPV specimen at PNNL. Welds in the PNNL specimen joined three plates. The heat number and slab number were identification numbers given by the plate vendor (Lukens Steel). The piece mark was an identification number given by the vessel maker, Chicago Bridge \& Iron (CB\&I).

Table 3.4 gives the amount of seam weld metal from two welds in the Hope Creek Unit 2 RPV specimen at PNNL. The Hope Creek Unit 2 RPV shell was built up from four rings. Axial seam BE joined two plates in forming Ring 2. Circumferential Seam AB jointed Ring 2 to Ring 1.

Table 3.3 Material from Three Base Metal Plates in the Hope Creek Unit 2 RPV Specimen at PNNL

\begin{tabular}{||l|c|c|c||}
\hline \hline & Heat Number & Slab & Piece Mark \\
\hline Plate 1 & C9634 & 2 & $22-1$ \\
\hline Plate 2 & C9533 & 1 & $22-3$ \\
\hline Plate 3 & C9570 & 2 & $21-2$ \\
\hline
\end{tabular}


Table 3.4 Seam Weld Metal from Two Welds in the Hope Creek Unit 2 PRV Specimen at PNNL

\begin{tabular}{||l|l|c||}
\hline \hline & \multicolumn{1}{|c|}{ Type } & Length at PNNL \\
\hline Seam BE & Axial & $117 \mathrm{~cm}$ \\
\hline Seam AB & Circumferential & $112 \mathrm{~cm}$ \\
\hline
\end{tabular}

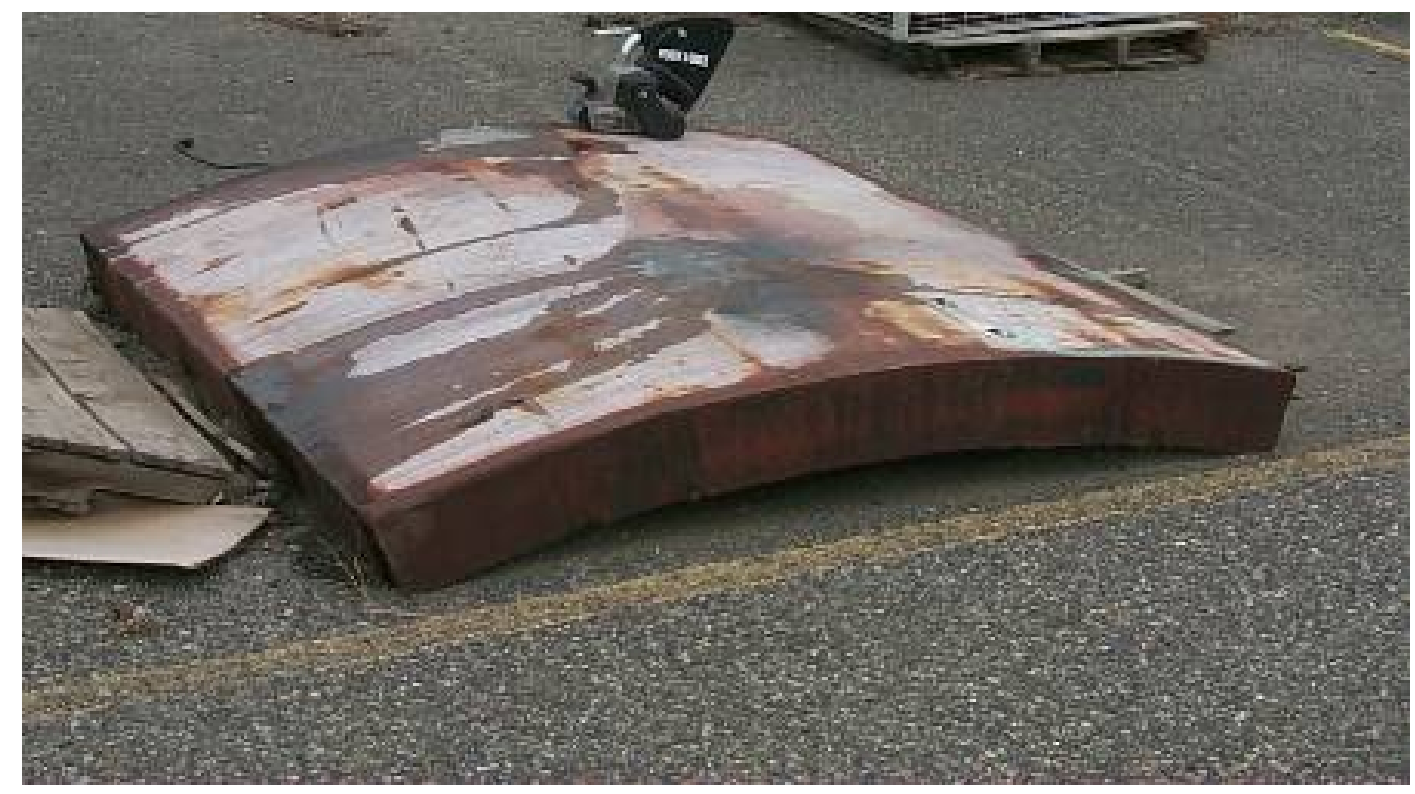

Figure 3.8 PNNL Reactor Pressure Vessel Specimen as Received from Hope Creek Unit 2

\subsection{River Bend Unit 2 Reactor Pressure Vessel Weldments}

PNNL acquired 15 m of girth weld from the River Bend Unit 2 reactor pressure vessel. Chicago Bridge \& Iron manufactured the vessel for the River Bend Nuclear Plane Unit 2. Unit 2 was a BWR 6 design but was cancelled. The vessel was dismantled in 1996.

The base metal is A533B bent plate, $15 \mathrm{~cm}$ thick. The locations of the welds were indicated on the outside of the specimen by triple punch marks and numbers used in the radiography performed during construction. The PNNL weld specimens contained a portion of the circumferential seam weld AD. This weld joined the upper shell course to the upper intermediate one. There were no documented repairs in the weld that PNNL received from River Bend Unit 2.

After cut and machined surfaces were prepared, the twelve specimens were taken to the NDE Laboratory for ultrasonic inspection. Inspection of the weld in the PNNL specimens from the River Bend Unit 2 RPV was conducted from a cut and machined surface. These measurements were used to search for undocumented repairs and form the initial, un-validated flaw density and distribution within the weld. The PNNL staff used a $5 \mathrm{MHz}$ contact probe for the ultrasound and heavy mineral oil as a couplant. SAFT-UT images of the weld regions provided sensitive measurement of the welds and surrounding base metal. No undocumented repairs were found. 


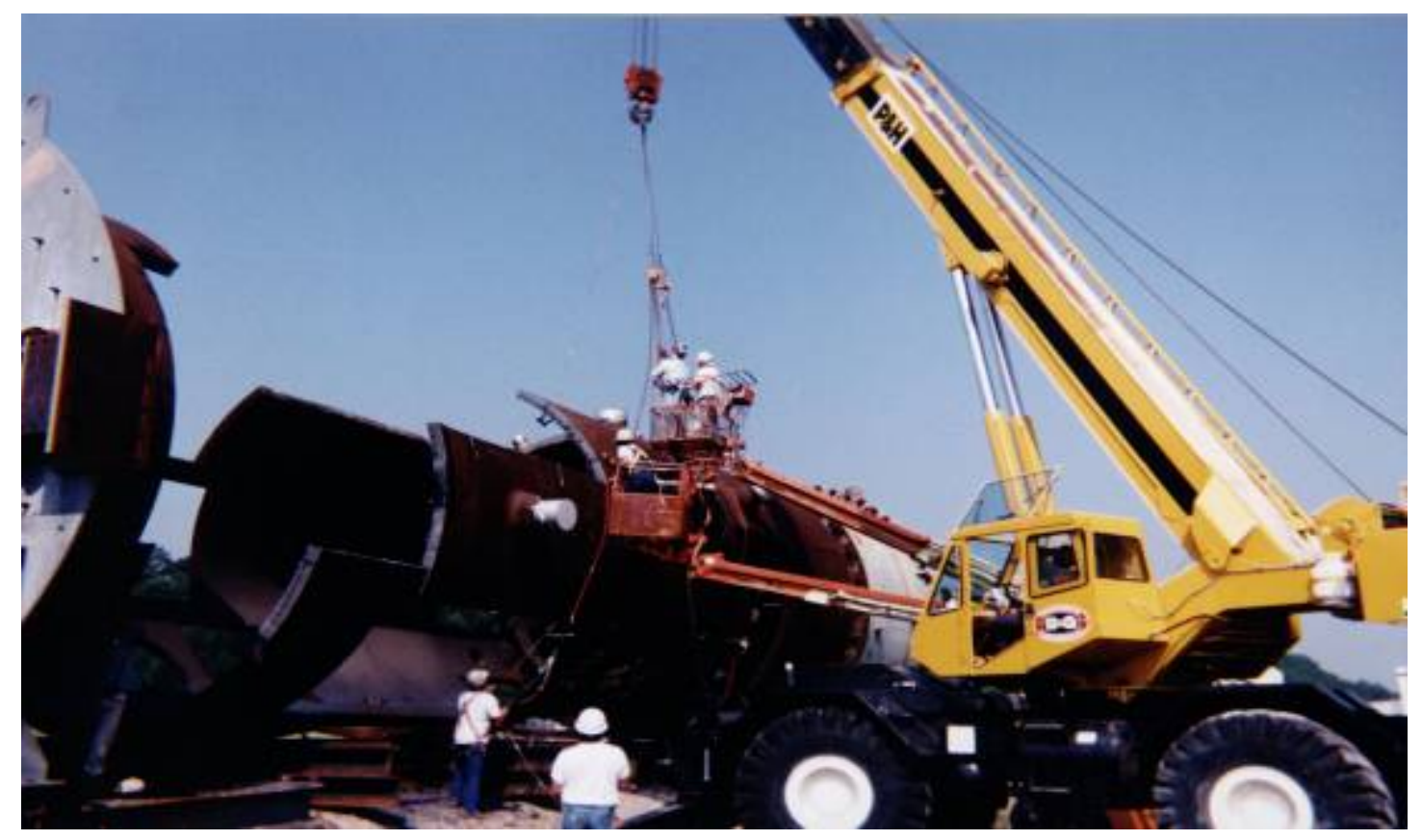

Figure 3.9 River Bend Unit 2 RPV During Disassembly

\subsection{Archived Pipe Weldments}

PNNL performed NDE inspections and destructive analysis on archived piping welds to determine the fabrication flaw size and distribution characteristic of piping welds in nuclear plants. Several appropriate piping sections were identified and made available, including samples representing several base materials and weld techniques. A description of the source of the pipe welds is provided below.

The pipe welds inspected all came from Battelle-Columbus. Each of the welds was fabricated by a nuclear certified welder using procedures certified for use in actual nuclear power plant applications. Battelle-Columbus obtained these pipe sections and associated welds from two different sources. The 20cm-nominal-diameter stainless steel pipes were obtained from Duquesne Light Company, operators of the Beaver Valley Nuclear Power Plant. The 20-cm-diameter Schedule 80 pipe was Type 304 stainless steel. The 20-cm-diameter Schedule 160 pipe was Type 316 stainless steel. The two welds were made using the gas-tungsten-arc weld (GTAW) process for the root passes and the shielded-metal-arc weld (SMAW) process for the fill passes. Both pipe welds were specially fabricated for Battelle to be used in a program to evaluate the acceptability of leak-before-break for the Beaver Valley plant. Although this program was subsequently cancelled, the operators of Beaver Valley donated the pipe and associated welds to Battelle-Columbus to be used in some of its ongoing piping research programs.

Battelle-Columbus originally obtained the remainder of the pipe and associated welds from a cancelled Combustion Engineering plant. The 30-cm-nominal-diameter pipe was to have been used as part of the surge line for this plant. Battelle-Columbus provided PNNL with two of these surge line welds. The two welds were at the two ends of a long-radius elbow where a straight pipe section joined to the elbow. The pipe and elbow were nominally 30-cm-diameter Schedule 160 in size. The material for both the pipe and elbow was a CF8M cast stainless steel. The larger-diameter, heavier wall pipes and elbows (nominally 
$91 \mathrm{~cm}$ in diameter by $7.6 \mathrm{~cm}$ thick) were to have been used in the fabrication of the cold leg for this plant-Figure 3.10 for an illustration. The pipe and elbow material was nominally carbon steel (A516 Grade 70) with an explosively bonded stainless steel cladding on the inside surface. The welds subjected to the detailed NDE as part of this effort were dissimilar, shop-fabricated welds joining the carbon steel pipe or elbow to a stainless steel safe end. The safe end was a forging of F316 material that would have been welded in the field to one of the stainless steel pump housings associated with the primary loop piping system. The dissimilar welds were made by first buttering the carbon steel pipe (or elbow) with Inconel 182 weld rod and then joining the buttered pipe to the stainless steel safe end using an Inconel 182 SMAW process. One of these dissimilar metal welds contained the weld repairs analyzed in this study and described in this report.

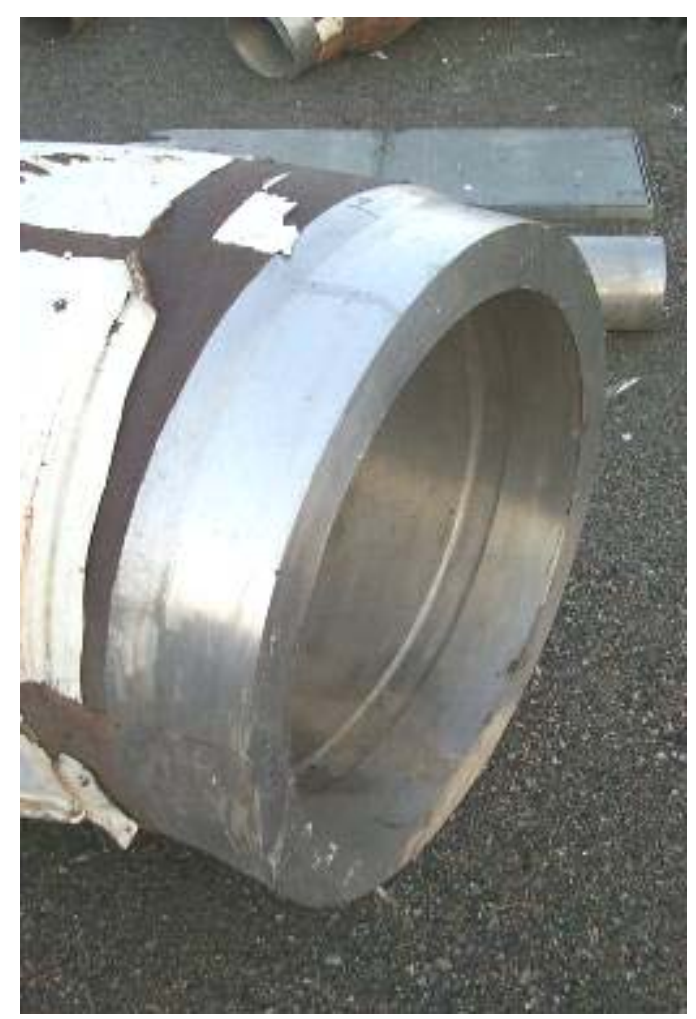

Figure 3.10 Dissimilar Metal Weld Specimen at PNNL - Safe End to 91-cm-Diameter Carbon Steel Elbow Weld 


\subsection{Repair Flaw Morphology and Fracture Mechanics Considerations}

The complex shape and form of repair flaws is described in Section 4.1. A discussion of fracture mechanics considerations for using distributions of such flaws in failure calculations follows in Section 4.2.

The flaw distribution methodology addresses only fabrication flaws, with no consideration of serviceinitiated cracks or service-related growth of fabrication flaws by fatigue or stress corrosion cracking. Service history and fracture mechanics calculations provide no reason to believe that crack initiation or growth for flaws in the vessel beltline region are likely.

PNNL's examination of vessel material showed that most weld flaws of significant size were located at the weld fusion lines and had orientation to follow the weld fusion lines. This trend occurred for flaws in original seam welds and for flaws associated with weld repairs. This information was used to modify assumptions used in fracture mechanics calculations performed with the fracture mechanics code. Flaws associated with seam weld repairs are assumed to propagate into either the base metal or weld metal. Cracks are assumed to propagate into the material with the lowest level of fracture toughness.

The weld examinations by SAFT-UT gave special consideration to indications that would give the appearance of one or more flaws that may in fact be one larger flaw. Subsequent validation efforts focused on these regions for more accurate characterization of the flaw dimensions. ASME Code flaw proximity rules were then applied to the NDE results. The dimensions of multiple flaws were tabulated as a single larger flaw if so dictated by the application of code proximity rules. The database on flaws should therefore be considered as accounting for random occurrences of small flaws that are sufficiently close to each other to be properly treated as a single larger flaw in fracture mechanics calculations. The flaws that are entered into fracture mechanics calculations are treated as single isolated flaws. There should be no further steps in the fracture mechanics models to simulate random locations of flaws in order to identify occurrences of adjacent flaws that should be treated as a single larger flaw.

All flaws are to be treated as crack-like flaws, which is consistent with the generally planar nature of the flaws observed in the PNNL examinations. It was recognized that the treatment of flaws by the fracture mechanics code assumes planar flaws having ideal elliptical shapes. In fracture mechanics code, the plane of the cracks and major and minor axes of the cracks are aligned with the radial and axial coordinates of the vessel.

The PNNL measurements of flaws gave the dimensions of the flaws in the vessel coordinate system. This is sometimes described as putting a "box" around the flaw because no attempt is made to describe flaw orientation with respect to the vessel's coordinate system. In the case of fusion line flaws in seam welds, the dimensions of the flaw alone provide a realistic representation of the flaw for fracture mechanics calculations. However, complex repair flaws tend to have an orientation that can be described by major and minor axes that do not align with the vessel's coordinate system. PNNL describes complex repair flaw orientation in terms of these major and minor axes dimensions. Fracture mechanics tells us that orientation is important to preclude an overly conservative treatment of repair flaws. 


\subsection{Morphology of Repair Flaws}

The complex shape and form of repair flaws are discussed in this section. The location of the flaws is provided with a description of their composition. Radiography, ultrasound, metallography, electron images, and atomic element analysis are included.

The largest repair flaw found in a seam weld of the PVRUF reactor pressure vessel had a through-wall dimension of $17 \mathrm{~mm}$. Figure 4.1 shows radiographic images of this PVRUF 17-mm flaw in a repair to the beltline weld of PVRUF reactor pressure vessel. The repair was made from the outside diameter (OD) of the vessel to a depth of $16.5 \mathrm{~cm}$. The start of the flaw is labeled on Figure 4.1, and the flaw continues for three weld passes. The individual weld passes are labeled in Figure 4.1. At the end of the third weld pass, the flaw changes from side-wall lack of fusion to inter-run lack of fusion (between the repair metal weld passes). Figure 4.2 is a micrograph of a portion of the PVURF 17-mm flaw. The heat-affected zone, base metal, repair metal, and machine-made submerged arc weld (SAW) are labeled. The location of this portion of the PVRUF 17-mm flaw is in the fusion zone of the repair metal. The composition of the flaw is slag, porosity, and contamination. Figure 4.3 is a micrograph showing a magnified view of a portion of the PVRUF 17-mm flaw. A crack-like discontinuity is visible. Figure 4.4 is another micrograph showing a magnified view of a crack-like portion of the PVRUF $17 \mathrm{~mm}$ flaw. The crack originates from a small contaminated region between the weld beads. Figure 4.5 is a weld-normal UT C-Scan image of the weld fusion zone showing the profile of the weld repair cavity containing the PVRUF 17-mm flaw. The cavity profile is a low-energy signature produced by an absence of small discontinuities in the repair metal. The PVRUF 17-mm flaw is labeled in Figure 4.5.

The second largest flaw found in a seam weld repair in PNNL's specimens from the PVRUF reactor pressure vessel had a through-wall dimension of $12 \mathrm{~mm}$. Figure 4.6 is a focused ultrasound $(10 \mathrm{MHz})$ image showing the top view of the PVRUF 12-mm repair flaw. Like all large repair flaws, it is located on the end of the repair in the fusion zone of the repair metal with surrounding metal. Vessel through-wall direction is into the page. The distance along the beltline weld is on the ordinate. This image shows that the flaw is oriented principally in the axial direction. Figure 4.7 is a focused ultrasound $(10 \mathrm{MHz})$ image showing a side view of the PVRUF 12-mm flaw. The vessel through-wall direction is on the ordinate. Distance from weld center is into the page. Distance along the beltline weld is on the abscissa.

Figure 4.8 is a focused ultrasound (10 MHz) image showing an end view of the PVRUF 12-mm flaw. Vessel through-wall direction is on the ordinate. Distance from weld center is on the abscissa. Distance along the beltline weld is into the page.

Figure 4.9 shows a high-resolution image of the Shoreham 14-mm repair flaw. The flaw is located near the vessel outside surface in a repair made from the vessel outside surface. Figure 4.9 shows the side-wall lack of fusion covering three weld passes and then the inter-run lack of fusion. The weld-normal image of this indication can be found in Schuster et al. (1999, p. J.9). The through-wall dimension of the weldnormal indication was $14 \mathrm{~mm}$.

Figure 4.10 is a weld-normal UT C-Scan image of flaws in the fusion zone and on one end of the repair cavity for repair C in the Hope Creek Unit 2 reactor pressure vessel weld seam BE. Flaw 2 was extracted into cube form as specimen C2CC. Figure 4.11 shows a micrograph, as machined, of a portion of the crack in Hope Creek 2 RPV Specimen C2CC. The winding nature of the crack is evident, with microcracking on one of the branches. This is a hot crack. 
Fabrication cracks are typically one of two general kinds. Cold cracking, also called heat-affected zone cracking, occurs during cooling when the stress of solidification causes the weaker solid metal adjacent to a weld bead to crack. The second type is hot cracking. A weld solidification crack is a type of hot crack that occurs in the weld metal of various alloys. It is not a problem except in cases in which the welding process is improperly controlled. Yet the occurrence of such cracks can greatly reduce the strength and integrity of welded components and is one of the serious problems in the welding of high-strength steels (Morgan-Warren and Jordan 1974).

Hot cracking takes place as a result of the strains set up during the welding and occurs in thin films of nonmetallic segregates or by segregation of alloy elements, both of which lead to intergranular surfaces that solidify after the rest of the weld metal. Propagation of weld solidification cracks from weld pass to weld pass is described in (Kou and Le 1985). Solidification cracking is intergranular and propagates due to the thermal stresses and contamination acting behind the solidifying pool.

Hot cracking, which includes weld solidification cracks, is intergranular and winding, and can occur as multiple cracks (Ekstrom and Wale 1995). The most common orientation is cracking parallel to the weld direction, and the cracks can be located in the weld center. Hot cracks may occur in directions parallel to the solidification direction of the weld metal. An example of hot cracking in austenitic stainless steel weld metal is shown in Ekstrom and Wale (1995).

Lack of fusion is a weld discontinuity that is oriented along the fusion line of the weld with the base metal (Ekstrom and Wale 1995; Thielsch 1965). These discontinuities also occur between the weld passes. Lack of fusion is characterized in the literature as narrow, making it distinct from slag inclusions, which are round. Lack of fusion is also characterized as unbranched so as to be distinct from cracks. Lack of fusion can be oxide-filled.

Figure 4.12 is a second micrograph, as machined, of a portion of the crack in Hope Creek 2 RPV Specimen C2CC. The multiple cracking is evident in the micrograph. Figure 4.13 is a micrograph, as polished and etched, of a portion of the crack in Hope Creek 2 RPV Specimen C2CC. The largest portion of the flaw, in this view, is shown to be on the fusion line between weld passes. Microcracking is also evident.

Figure 4.14, an electron image of a portion of two cracks in Hope Creek 2 RPV Specimen C2CC, shows the location, just above the lower crack, of the measurement of the elemental composition of the weld metal. Figure 4.15 gives the elemental composition of weld metal near the crack, and Figure 4.16 provides the x-ray spectrum from that elemental analysis.

Figure 4.17, an electron image of a portion of a crack in Hope Creek 2 RPV specimen C2CC, shows the location, inside the upper crack, of the measurement of the elemental composition of the contamination in the crack. Figure 4.18 gives the elemental composition of contamination in the crack in Hope Creek 2 RPV Specimen C2CC; Figure 4.19 provides the x-ray spectrum from that elemental analysis. 


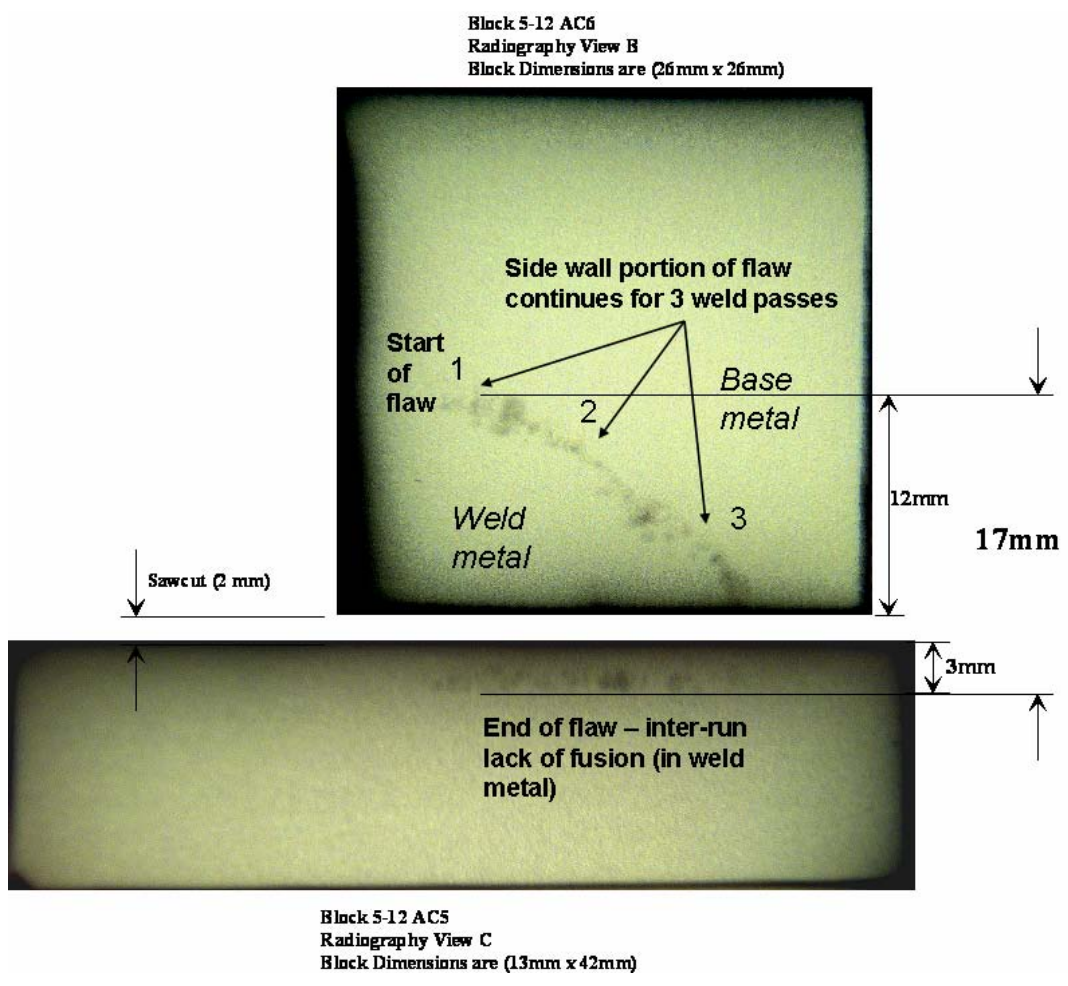

Figure 4.1 Radiographic Images of PVRUF 17-mm Flaw in OD Seam Weld Repair. The location of this repair flaw and the repair cavity surrounded by the original weld can be seen in Figure 4.5.

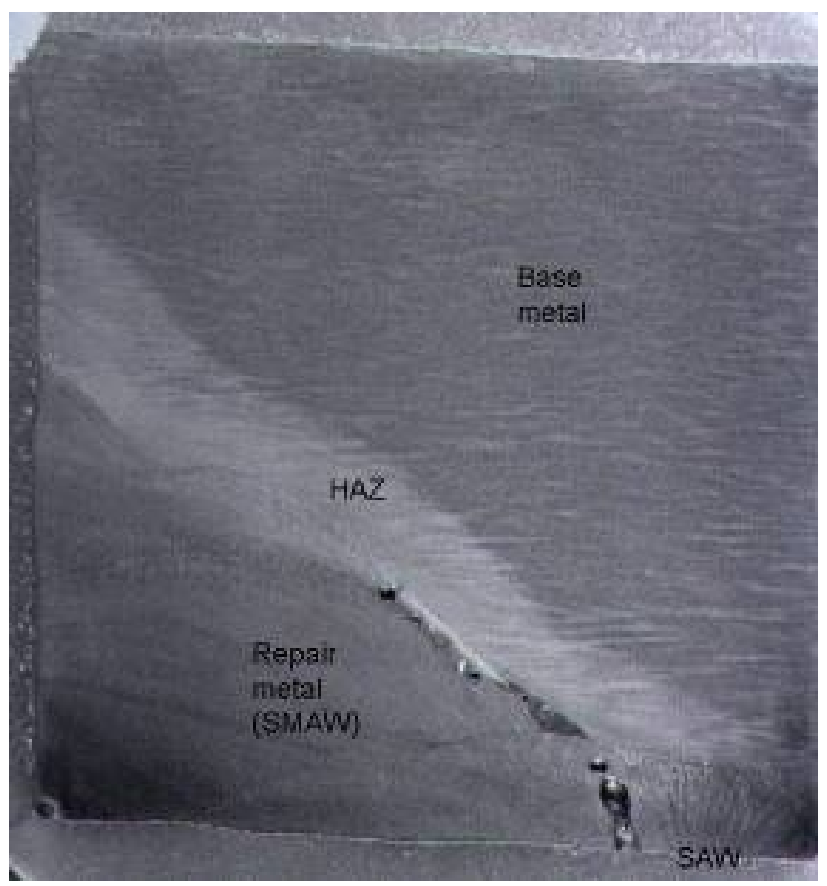

Figure 4.2 Micrograph of Portion of PVRUF 17-mm Flaw Showing Location and Composition 


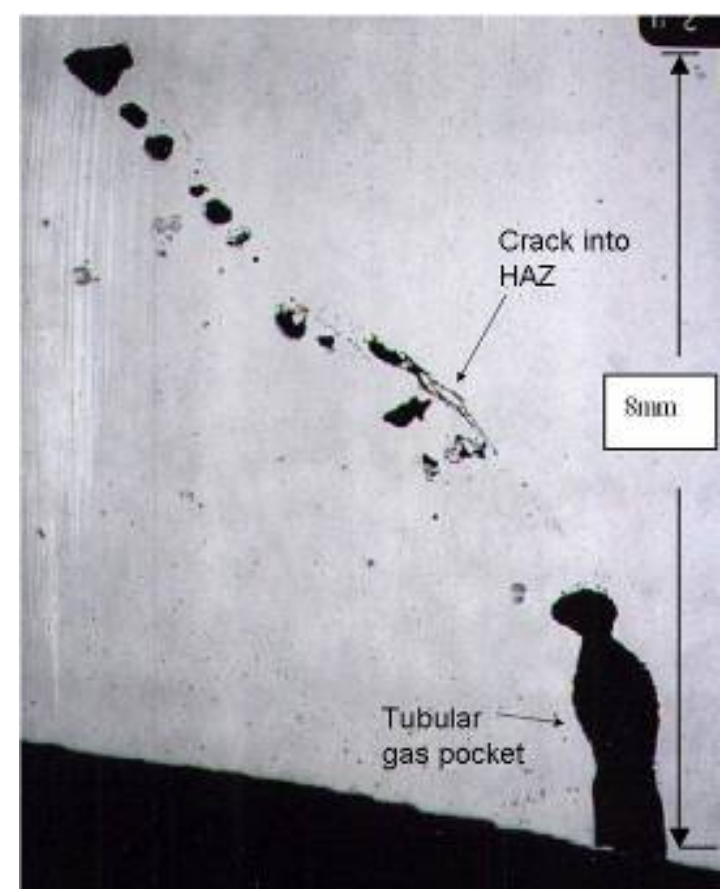

Figure 4.3 Micrograph Showing Magnified View of Portion of PVRUF 17-mm Flaw

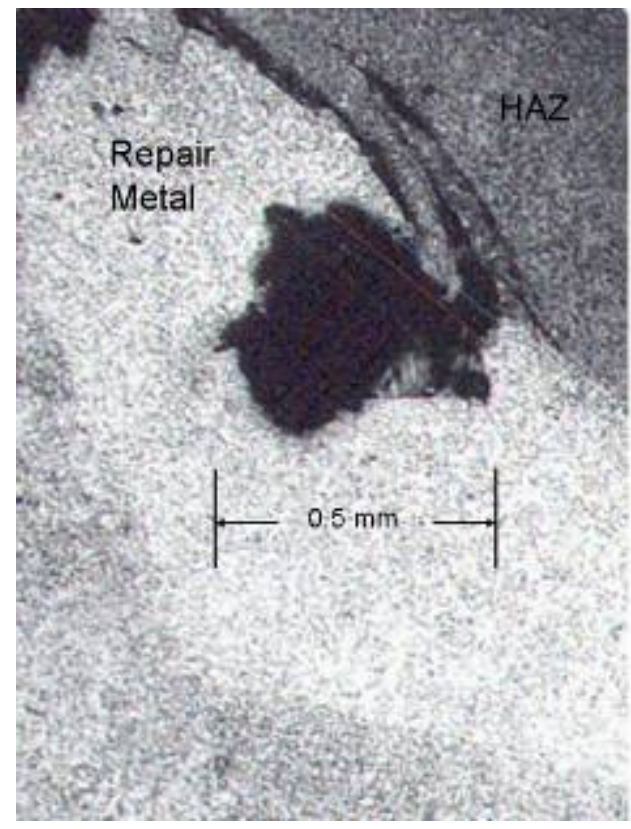

Figure 4.4 Micrograph Showing Magnified View of Crack-Like Portion of PVRUF 17-mm Flaw 


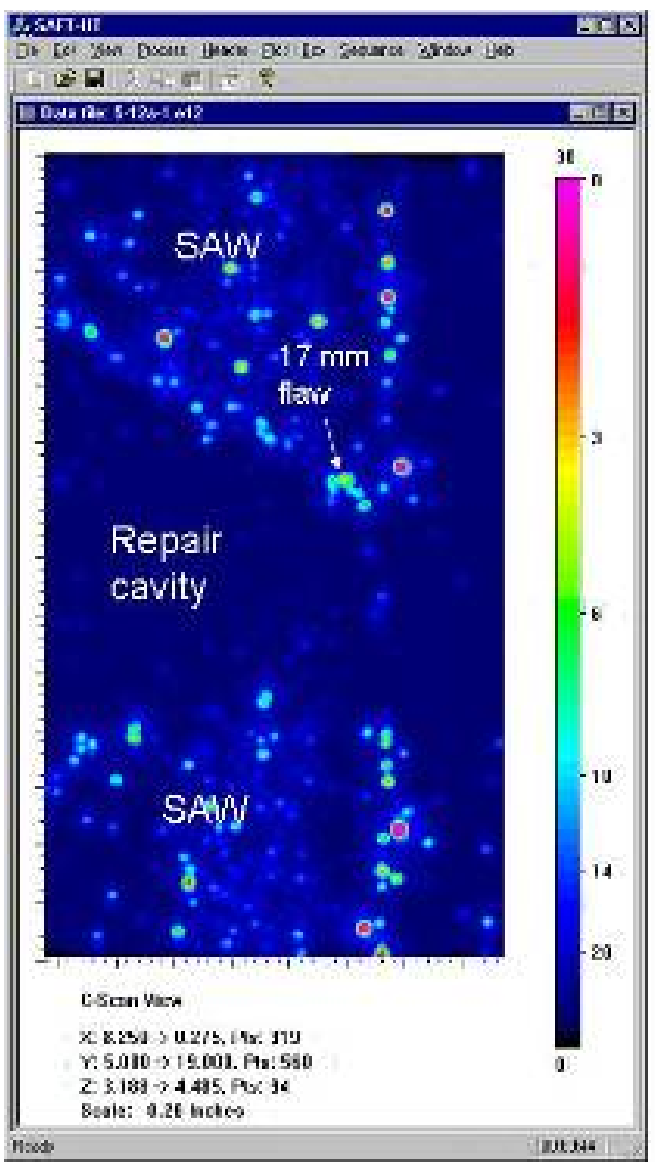

Figure 4.5 Weld-Normal UT C-Scan Image of Weld Fusion Zone Showing Profile of Weld Repair Cavity and Location of PVRUF 17-mm Flaw. To convert to centimeters, multiply by 2.54 .

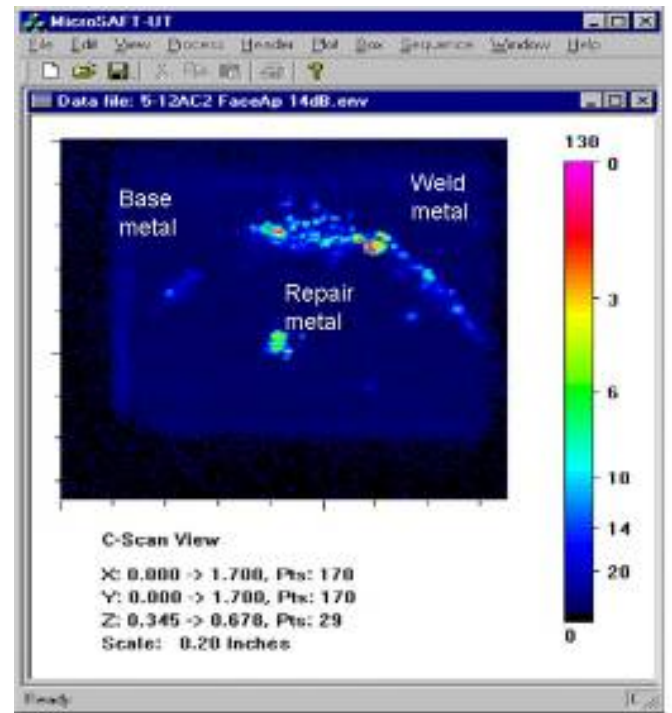

Figure 4.6 Focused Ultrasound (10 MHz) Result Showing Top View of PVRUF 12-mm Repair Flaw. To convert to centimeters, multiply by 2.54 . 


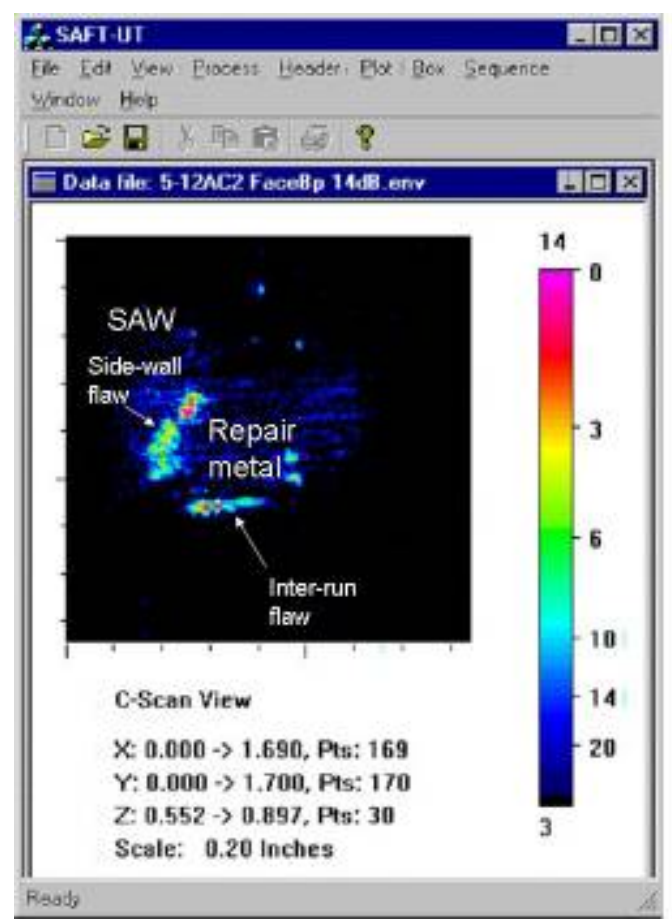

Figure 4.7 Focused Ultrasound (10 MHz) Result Showing Side View of PVRUF 12-mm Flaw. To convert to centimeters, multiply by 2.54 .

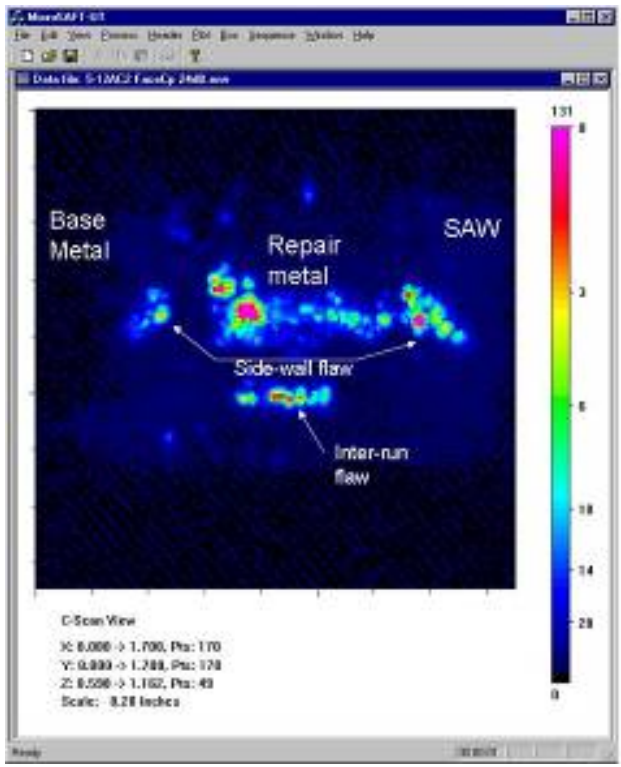

Figure 4.8 Focused Ultrasound (10 MHz) Result Showing End View of PVRUF 12-mm Flaw. To convert to centimeters, multiply by 2.54 . 


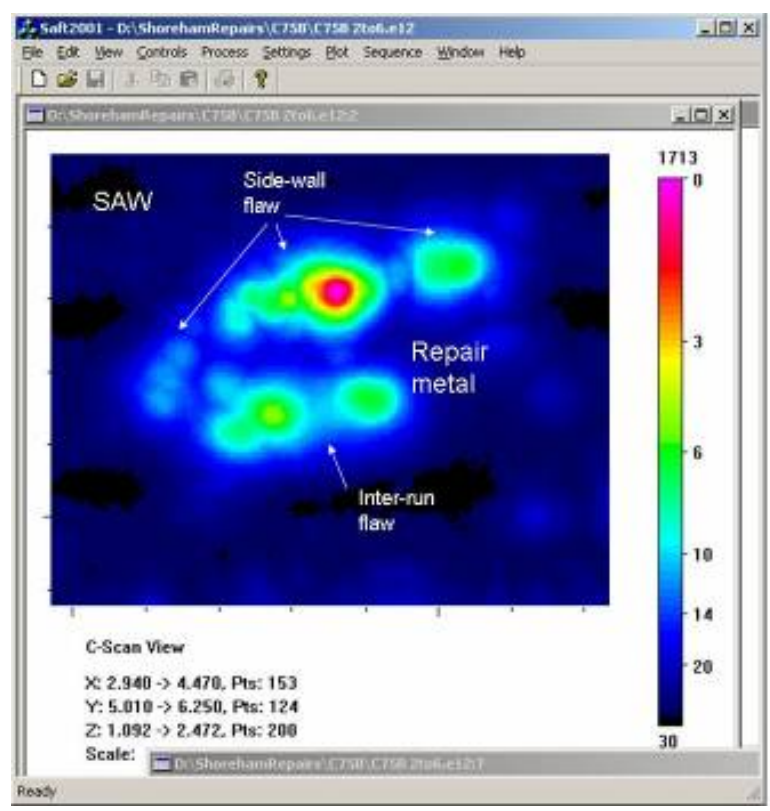

Figure 4.9 High-Resolution Image of Shoreham 14-mm Repair Flaw. To convert to centimeters, multiply by 2.54 .

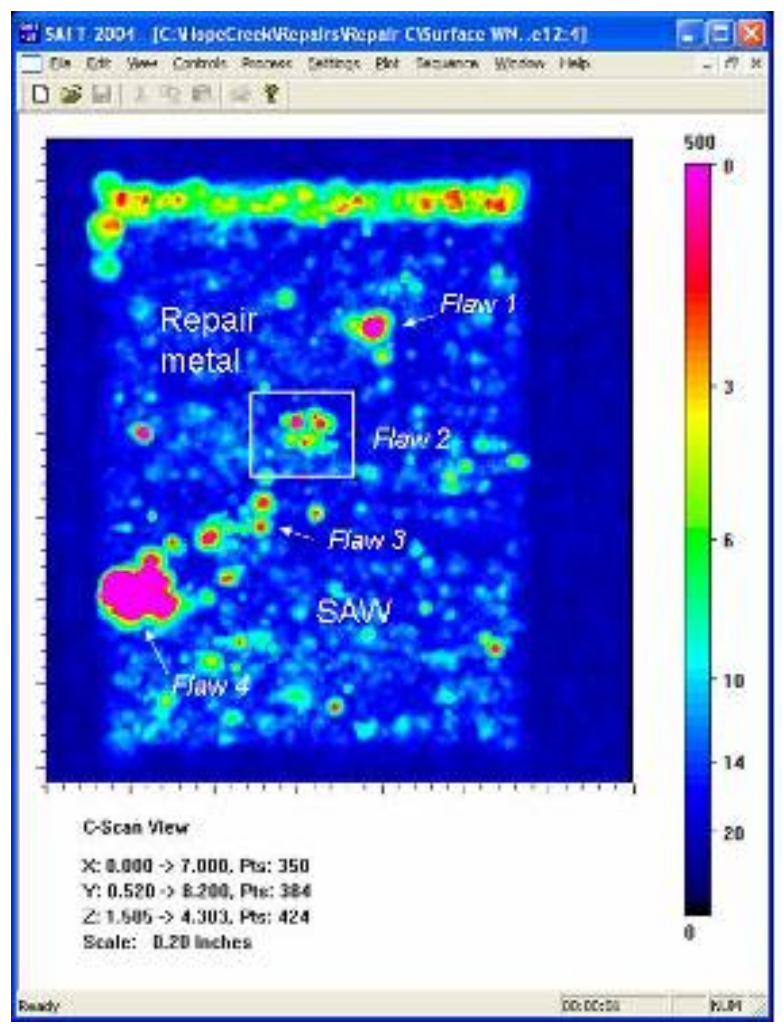

Figure 4.10 Weld-Normal UT C-Scan Image of Flaw in Fusion Zone and on End of Repair Cavity $\mathrm{C}$ in Hope Creek Unit 2 Reactor Pressure Vessel. To convert to centimeters, multiply by 2.54 . 


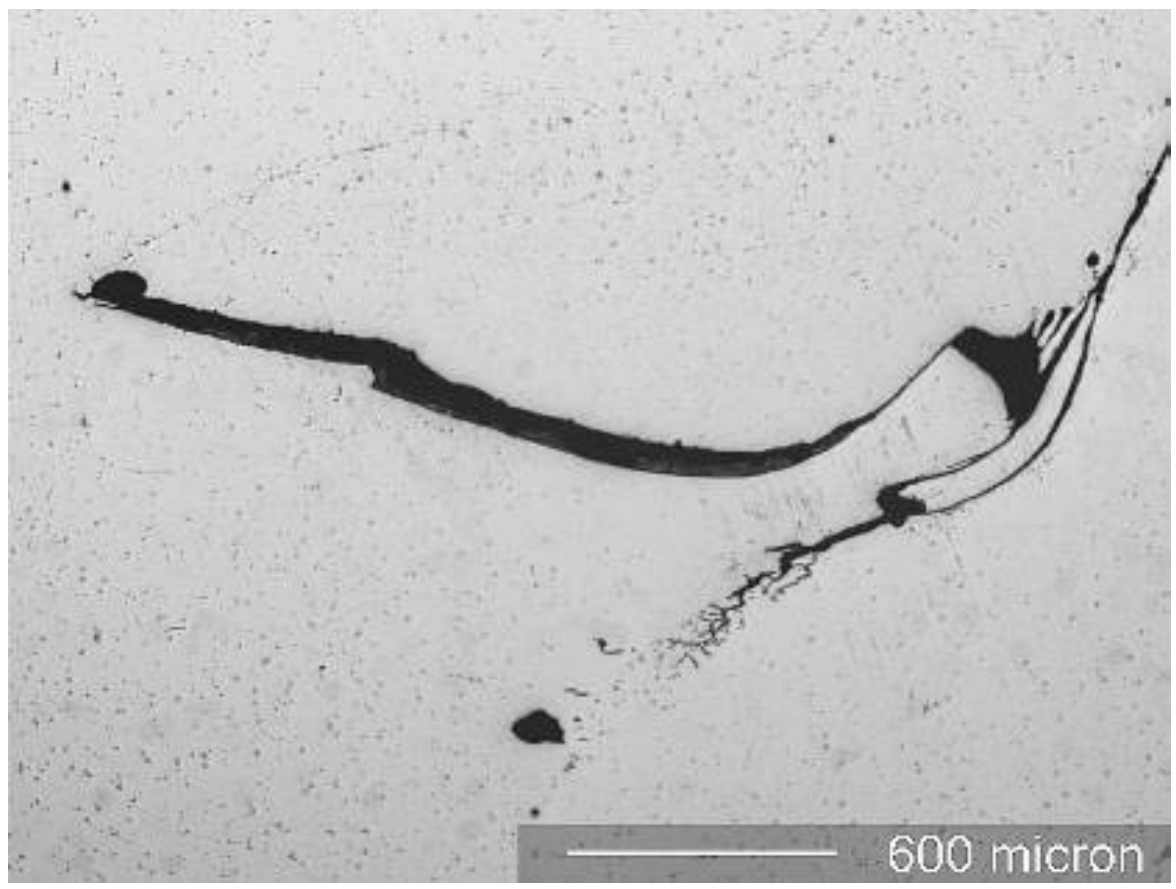

Figure 4.11 Micrograph, as Machined, of Portion of Crack in Hope Creek Unit 2 RPV Specimen C2CC

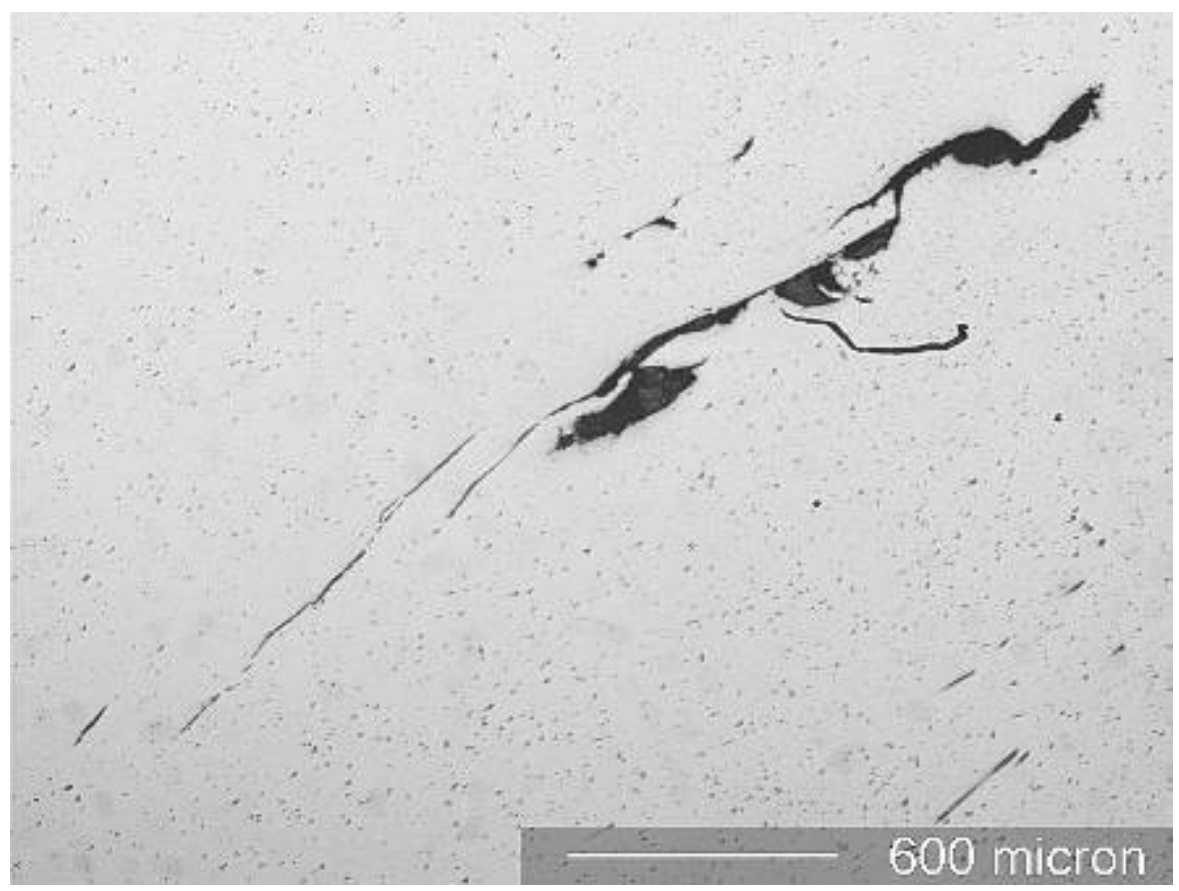

Figure 4.12 Micrograph, as Machined, of Portion of Crack in Hope Creek Unit 2 RPV Specimen C2CC 


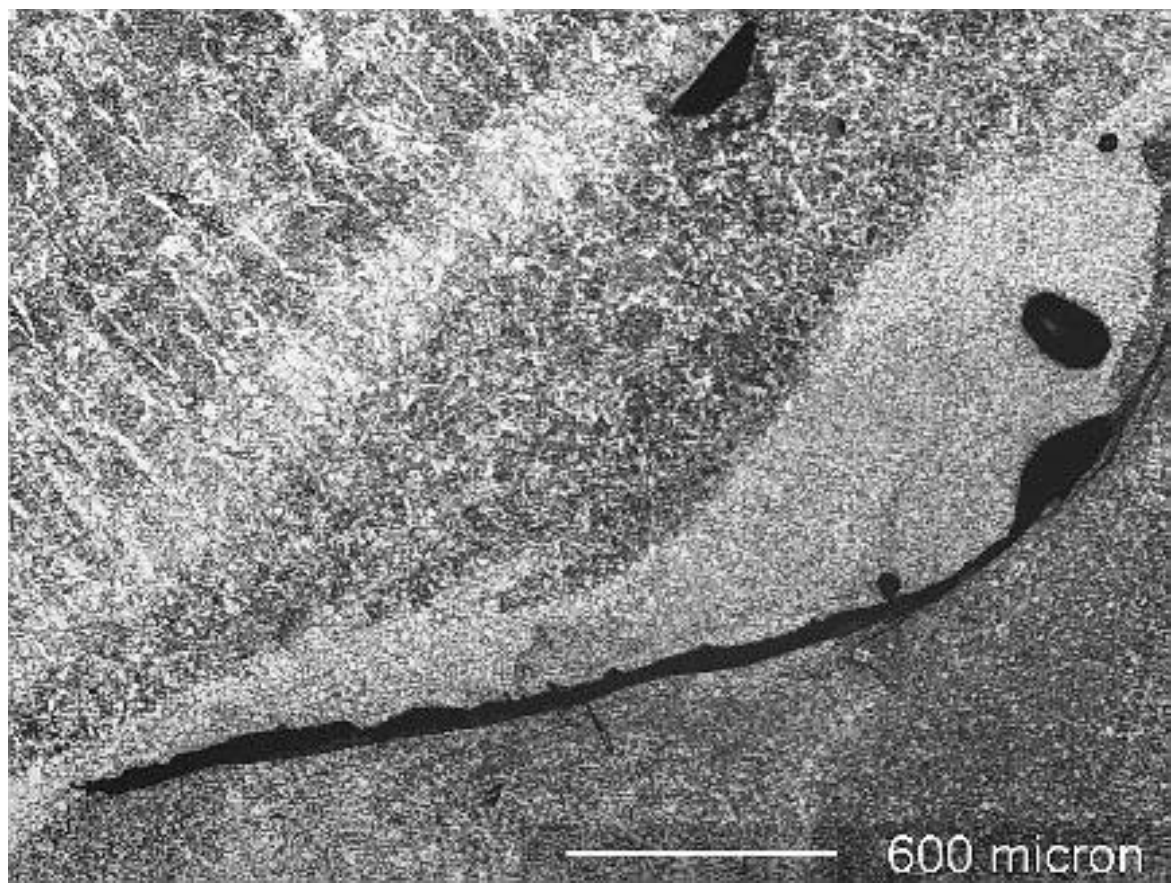

Figure 4.13 Micrograph, as Polished and Etched, of Portion of Crack in Hope Creek Unit 2 RPV Specimen C2CC

Upper crack branch, $\mathrm{COD}$ is 30 microns

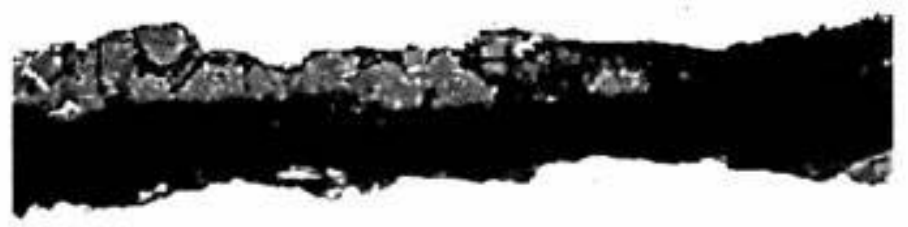

Lower crack branch. COD

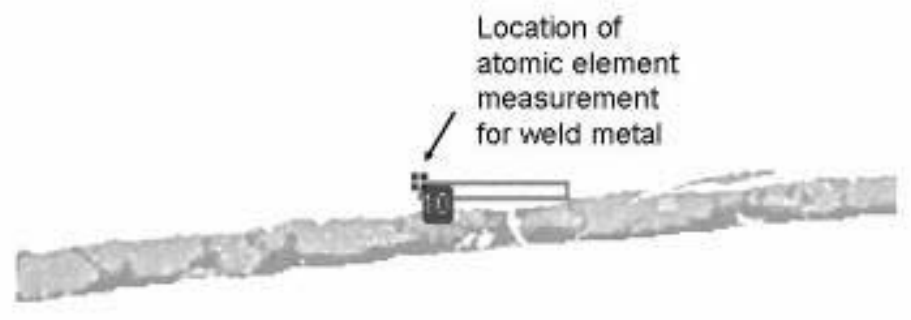

is 10 microns

$\overline{60 \mu m}$

Electron Image 1

Figure 4.14 Electron Image of Portion of Two Cracks in Hope Creek Unit 2 RPV Specimen C2CC 
Standard:

Mn Mn 1-Jun-1999 12:00 AM

Fe Fe 1-Jun-1999 12:00 AM

Ni Ni 1-Jun-1999 12:00 AM

\begin{tabular}{l|lllll}
\hline Element & $\begin{array}{l}\text { App } \\
\text { Conc. }\end{array}$ & $\begin{array}{l}\text { Intensity } \\
\text { Corrn. }\end{array}$ & Weight \% & $\begin{array}{l}\text { Weight \% } \\
\text { Sigma }\end{array}$ & Atomic \% \\
Mn K & 1.07 & 0.9777 & 1.43 & 0.17 & 1.45 \\
Fe K & 74.92 & 1.0009 & 97.73 & 0.27 & 97.75 \\
Ni K & 0.57 & 0.8797 & 0.84 & 0.22 & 0.80 \\
& & & & & \\
Totals & & & 100.00 & & \\
\hline
\end{tabular}

Figure 4.15 Elemental Composition of Weld Metal in Hope Creek Unit 2 RPV Specimen C2CC

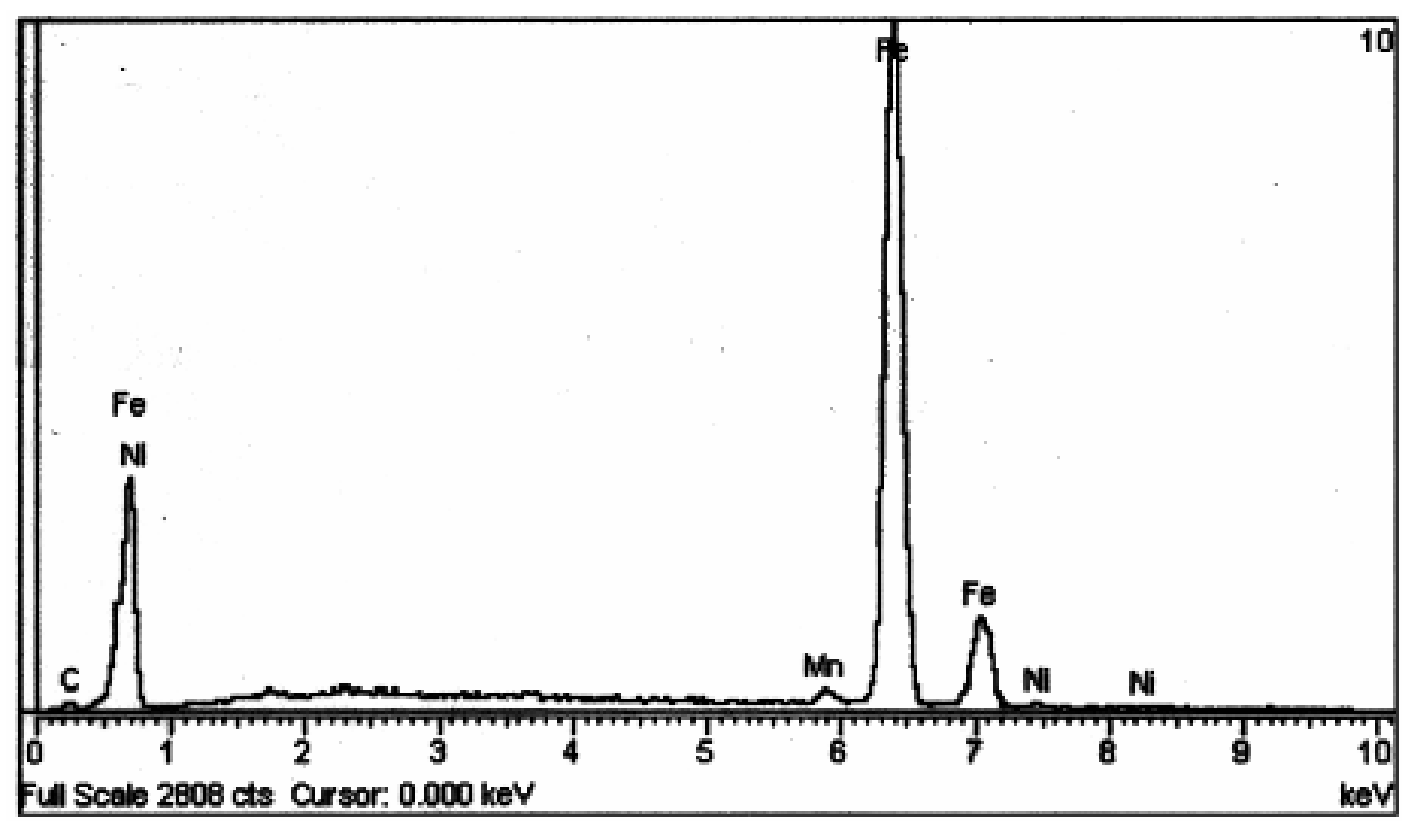

Figure 4.16 X-Ray Spectrum from Elemental Analysis of Weld Metal in Hope Creek Unit 2 RPV Specimen C2CC 


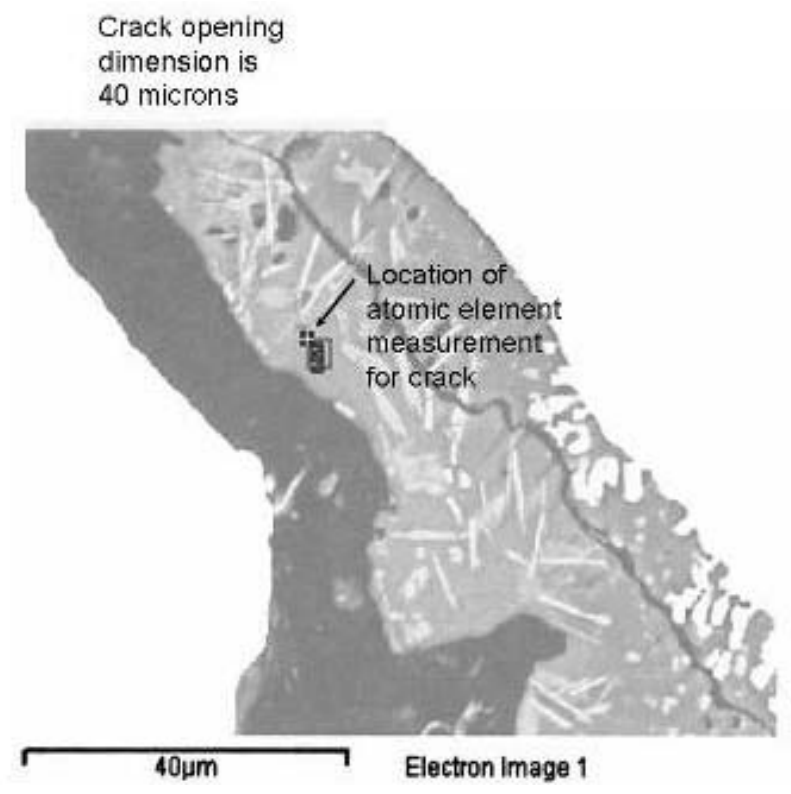

Figure 4.17 Electron Image of Portion of Crack in Hope Creek Unit 2 RPV Specimen C2CC

Standard:
O SiO2 28-Jan-2004 05:14 PM
Na Albite 1-Jun-1999 12:00 AM
Mg MgO 1-Jun-1999 12:00 AM
Al Al2O3 1-Jun-1999 12:00 AM
Si SiO2 28-Jan-2004 05:15 PM
S FeS2 1-Jun-1999 12:00 AM
K MAD-10 Feldspar 1-Jun-1999 12:00 AM
Ca Wollastonite 1-Jun-1999 12:00 AM
Ti Ti 1-Jun-1999 12:00 AM
Mn Mn 1-Jun-1999 12:00 AM
Fe Fe 1-Jun-1999 12:00 AM
Element

Figure 4.18 Elemental Composition of Contamination in Crack in Hope Creek Unit 2 RPV Specimen C2CC 


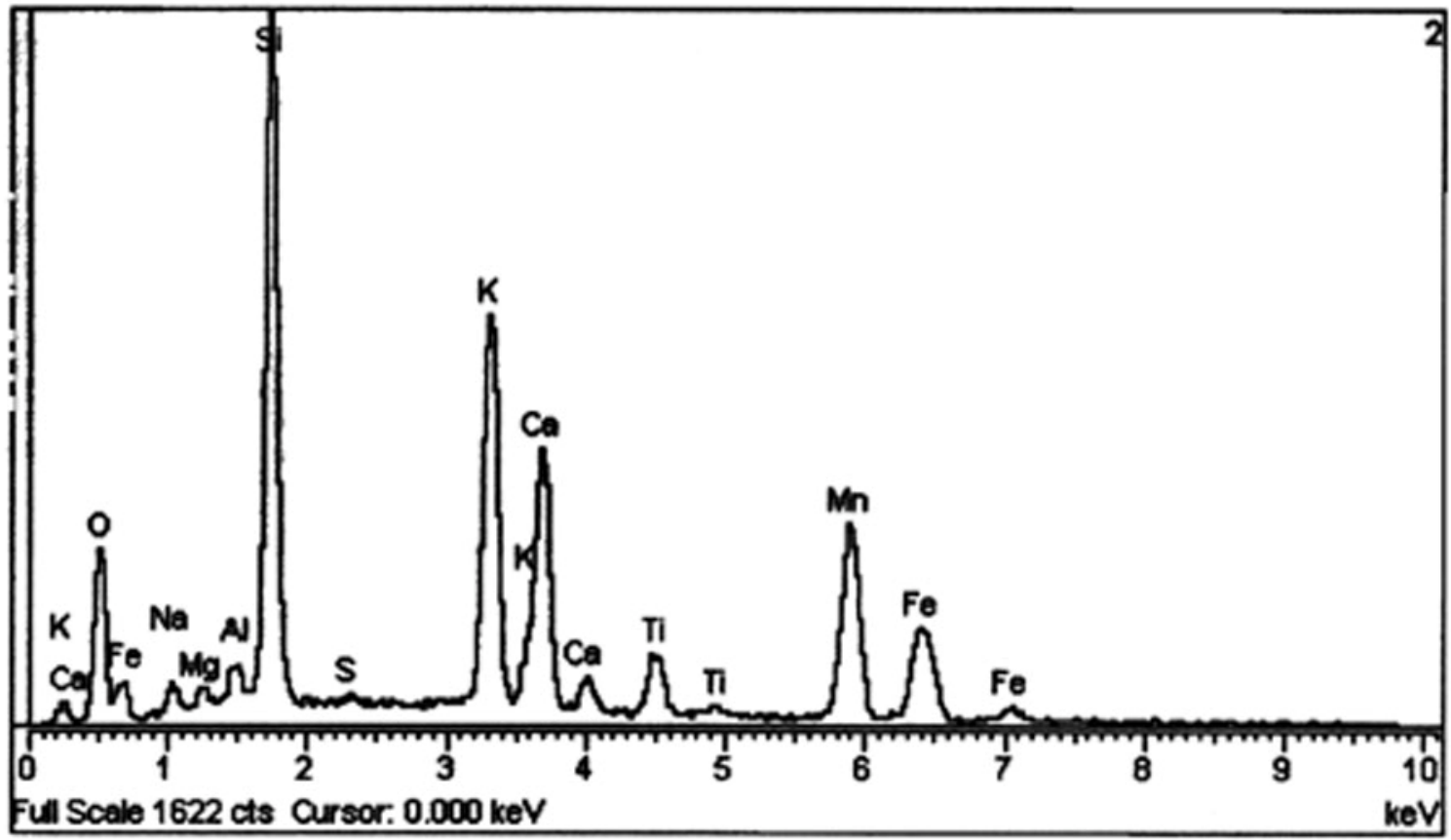

Figure 4.19 X-Ray Spectrum from Elemental Analysis of Contamination in Crack in Hope Creek Unit 2 RPV Specimen C2CC

\subsection{Fracture Mechanics Considerations for Repair Flaws}

Fracture mechanics calculations assume that flaws in welds occur in simple stylized geometries. Actual flaws are then approximated as planar elliptical cracks, with the crack plane and the major and minor axes of the flaws aligned with coordinates of the vessel (axial, circumferential, and radial directions). In the case of weld fusion line flaws observed in vessels, such approximations are reasonable and are not expected to lead to misleading or overly conservative predictions of vessel failure probabilities. However, the relatively large flaws in weld repairs depart significantly from the simplified flaw geometries. It is therefore important to develop fracture mechanics inputs (flaw orientations and dimensions) that are consistent with flaw measurements and at the same time are simplified to the degree needed to apply existing fracture mechanics models. The discussion in this section describes the approach used by PNNL to establish fracture mechanics input parameters based on the best available measurements of the dimensions and orientations of the larger repair flaws in vessels. The characterizations reported here make use of refined high-resolution SAFT scans of repair flaws performed after the flaws had been removed from the welds and placed in the form of relatively small specimens.

Figures 4.20 through 4.23 are sketches based on measurements and interpretations of SAFT images of large flaws associated with repairs in vessels. For simplicity, these flaws will be referred to as repair flaws. The flaws are designated here in terms of nominal through-wall dimensions from measurements made prior to the validation efforts. In all cases, the flaws were non-planar, were at orientations other than the coordinate directions of the vessel, and consisted of complex morphologies. All flaws were located at the ends of weld repair cavities and represented discontinuities that are best described as an 
axial crack for repairs to circumferential welds or circumferential cracks for repairs to axial welds. The sketches of Figures 4.20 through 4.23 represent projections of the complex flaws onto the planes for idealizations as axial and circumferential flaws.

It should be noted that the nominal flaw sizes (in terms of through-wall extent) were in all cases established to be conservative relative to the subsequent measurements made during the validation part of PNNL's studies. The initial sizing measurements therefore provided a bound (based on the UT measurements) for regions that showed evidence of structural unsoundness. The region outside these bounding dimensions produced no signals other than background noise such as due to the material microstructure. The initial sizing measurements did not necessarily show the presence of a single planar crack as opposed to a cluster of cracks or other NDE indications such as those due to inclusions or material contamination. The images used to draw the sketches of Figures 4.20 through 4.23 showed more detail as to the structure of the flaws and defined dimensions of multiple flaws and their relative proximity to each other.

- 14-mm Shoreham Repair Flaw. The original measurements characterized this flaw with dimensions in vessel coordinates having a maximum through-wall dimension of about $14 \mathrm{~mm}$. The more refined SAFT examinations showed a more complex shape having two major subregions that could be connected (Figure 4.20) or unconnected (Figure 4.21). Fracture mechanics calculations would show that the flaw interpretation of Figure 4.21 would give a significantly smaller impact on structural integrity because the critical flaw dimensions have been reduced from a single flaw of $14 \mathrm{~mm}$ to separate flaws with dimensions of $4 \mathrm{~mm}$ and $5 \mathrm{~mm}$. There are uncertainties regarding the separation distance between the legs of the complex flaw and with the structural soundness of the region joining the ends of the two subregions. The recommendation, subject to change based on further steps in the validation effort, is to describe the flaw with a dimension of $14 \mathrm{~mm}$.

- 32-mm Shoreham Repair Flaw. The original measurements characterized this flaw with dimensions in vessel coordinates having a maximum through-wall dimension of about $32 \mathrm{~mm}$. The more refined SAFT examinations showed a flawed region bounded by dimensions of $12 \mathrm{~mm}$ and $44 \mathrm{~mm}$. The 32-mm maximum through-wall extent was confirmed showing an elongated flaw at an angle of about 45 degrees. The proper characterization of this flaw for fracture mechanics calculations of stress intensity factors would be a smaller flaw with dimensions having a depth of $12 \mathrm{~mm}$ and a length of $44 \mathrm{~mm}$. There are uncertainties regarding the possible separation of the single elongated flaw into separate flaws as indicated in Figure 4.23. However, the dimension of the ligament between the separate flaws is subject to uncertainties such that ASME Code flaw proximity rules would need to combine the two flaws into one flaw. The recommendation, subject to change based on further steps in the validation effort, is to describe the flaw as a single flaw with dimensions of $12 \mathrm{~mm}$ and $44 \mathrm{~mm}$. This characterization removes a large measure of conservatism from the earlier evaluation by dealing with the large apparent through-wall dimension of $32 \mathrm{~mm}$ with recognition of the 42-degree flaw orientation or rotation. The rotation decreases the measured maximum through-wall dimension of the flaw but does nothing to increase the value of the calculated crack-tip stress intensity factor.

The validation effort essentially confirmed the original characterizations of many of the large repair flaws, but in other cases the dimensions were significantly reduced because of fracture mechanics considerations. The primary consideration that allowed the less conservative treatments was recognition 
of the importance of flaw orientation and how a rotated orientation can decrease the measured throughwall dimension of a flaw. The validation measurements significantly reduced the dimensions of the 32-mm repair flaw.

Insights from fracture mechanics have been applied to interpret and characterize the large repair flaws pictured in Figures 4.20 through 4.23. The objective was to establish distributions for flaw dimensions that avoid excessive conservatism and that are consistent with the fracture mechanics approach used in the facture mechanics computer code. The following summarizes the conclusions of the effort:

1. Improved measurements from the validations for the complex Shoreham repair flaws and a fracture mechanics interpretation significantly changed the resulting distribution functions.

2. The most significant factor for characterizing repair flaws was the effect of flaw orientation. The improved characterization used the major and minor dimensions of the flaw rather than the conventional NDE procedure of reporting through-wall extent and flaw length.

3. The improved characterization of the complex nature of the repair flaws recognized that flaws often can be broken into two or more smaller flaws. The example flaws of this study were found to be sufficiently close to each other such that within the accuracy of the flaw measurements it was not possible to justify on the basis of ASME Code proximity rules treatments of these flaws as individual flaws.

4. Large repair flaws have been located at the ends of repair cavities. Such flaws are non-planar and not oriented in the directions (axial and circumferential) of the vessel coordinate system. The primary orientation for repair flaws in axial welds is circumferential. The primary orientation for repair flaws in circumferential welds is axial. It is, however, conservative (given the skewed orientations of the flaws and the current conventions used by the FAVOR code [Dickson 1944]) to treat such flaws in axial welds as axial flaws and flaws in circumferential welds as circumferential flaws.

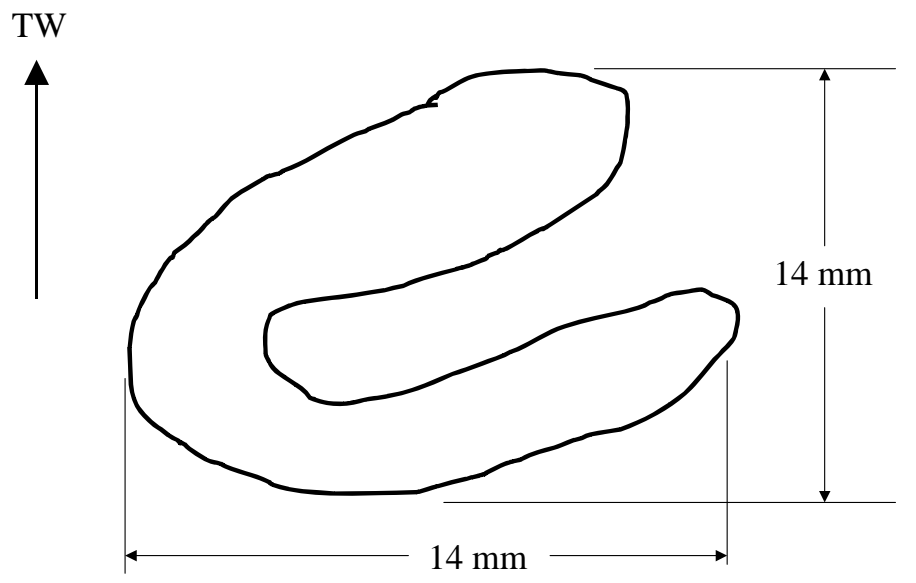

Figure 4.20 Shoreham 14-mm Repair Flaw with More Conservative Treatment A of Flaw Dimensions 


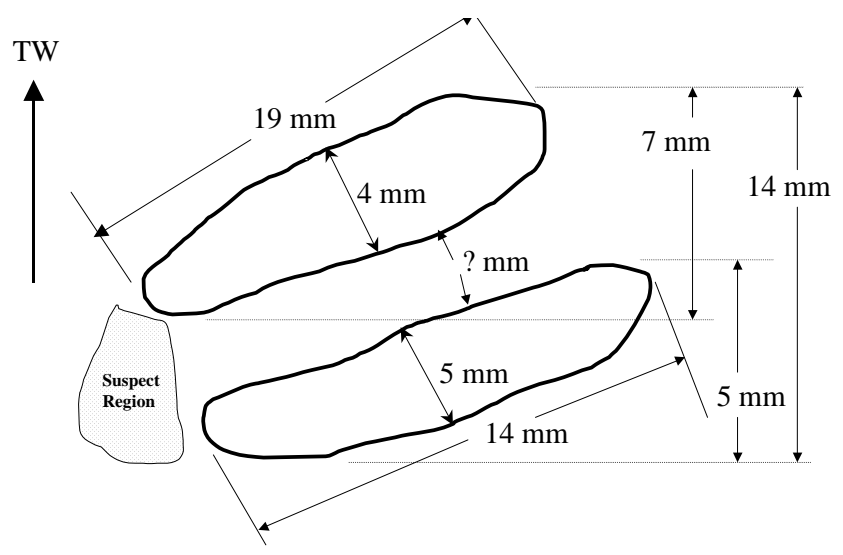

Figure 4.21 Shoreham 14-mm Repair Flaw with Less Conservative Treatment B of Flaw Dimensions

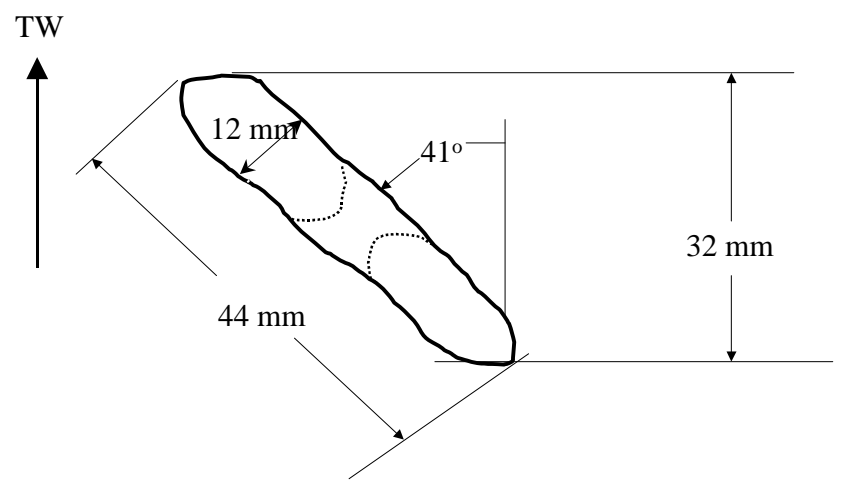

Figure 4.22 Shoreham 32-mm Repair Flaw with More Conservative Treatment A of Flaw Dimensions

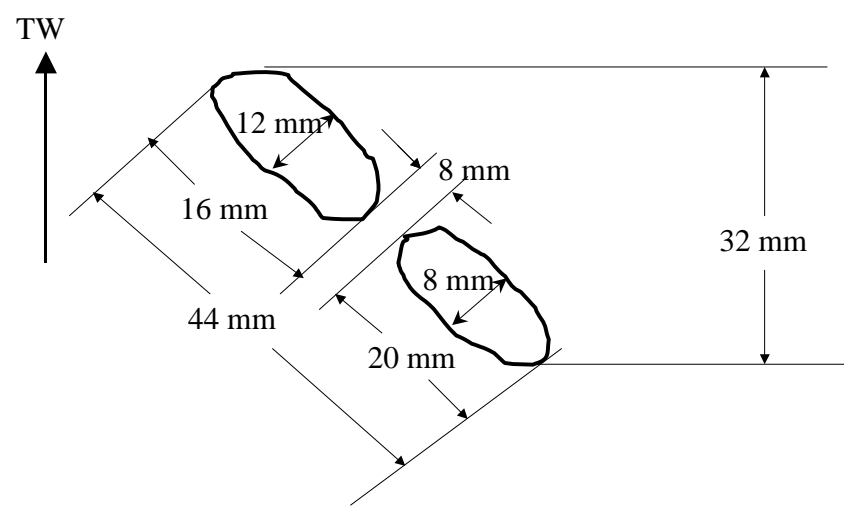

Figure 4.23 Shoreham 32-mm Repair Flaw with Less Conservative Treatment B of Flaw Dimensions 


\subsection{Confirmed Flaw Frequency and Distribution in Repairs}

This section describes the through-wall size distribution estimated using the results of the flaw measurements in the individual repairs of three reactor pressure vessels and the dissimilar metal welds of archived pipes. In the Shoreham vessel, two repairs to the seam welds were found in the specimens that we examined. In the PVRUF vessel, one repair was found. For the Hope Creek Unit 2 vessel, five repairs were found. The dissimilar metal welds of the piping specimens contained three repairs. No repairs were found in the River Bend Unit 2 weld specimens.

In this section, the cumulative flaw distributions are fit with an exponential function. The cumulative flaw density $\mathrm{y}(\mathrm{x})$ is given by

$$
y(x)=\alpha \exp (-\beta x)
$$

where $\mathrm{x}$ is the flaw size and $\alpha$ and $\beta$ are the parameters of the exponential fit. Traditional approaches quantify flaw density in terms of flaws per unit volume. PNNL's weld examinations, however, indicated that essentially all of the flaws with significant through-wall extent were located along weld fusion lines. Therefore, it was recognized that it would be best to describe weld flaw densities in terms of flaws per unit area of fusion zone. As a result, the units of the cumulative flaw density and the $\alpha$ parameter are flaws per square centimeter of repair surface area.

\subsection{Validated Flaw Density in Shoreham Reactor Pressure Vessel Repairs}

The PNNL specimens from the Shoreham reactor pressure vessel contained two repairs to the seam welds. Table 5.1 shows the through-wall dimension distribution for the six flaws found. The throughwall dimension is the maximum extent of the flaw along the vessels through-wall axis. Table 5.2 shows the reduced through-wall size for the six flaws. The reduced through-wall size, as described in Section 4.2, is the dimension of the minor axis of the flaw. Figure 5.1 charts the through-wall dimension and reduced size distribution for flaws in repairs in seam welds of the Shoreham reactor pressure vessel specimens.

Table 5.1 Through-Wall Dimension Distribution for Flaws in Shoreham Repairs

\begin{tabular}{||l|l|l|l|l|l||}
\hline Through-Wall Dimension & $\mathbf{7}(\mathbf{m m})$ & $\mathbf{1 0} \mathbf{( m m})$ & $\mathbf{1 4} \mathbf{( m m})$ & $\mathbf{2 1} \mathbf{( m m})$ & $\mathbf{3 2}(\mathbf{m m})$ \\
\hline Frequency & 2 & 1 & 1 & 1 & 1 \\
\hline Cum. Freq. & 6 & 4 & 3 & 2 & 1 \\
\hline Density $\left(\mathrm{cm}^{-2}\right)$ & 0.0044 & 0.0029 & 0.0022 & 0.0014 & 0.00073 \\
\hline
\end{tabular}

Table 5.2 Reduced Through-Wall Size Distribution for Flaws in Repairs

\begin{tabular}{||l|l|l|l|l|l||}
\hline Through-Wall Dimension & $\mathbf{6}(\mathbf{m m})$ & $\mathbf{7}(\mathbf{m m})$ & $\mathbf{1 0}(\mathbf{m m})$ & $\mathbf{1 2}(\mathbf{m m})$ & $\mathbf{1 4} \mathbf{( m m})$ \\
\hline Frequency & 1 & 1 & 2 & 1 & 1 \\
\hline Cum. Freq. & 6 & 5 & 4 & 2 & 1 \\
\hline Density $\left(\mathrm{cm}^{-2}\right)$ & 0.0044 & 0.0036 & 0.0029 & 0.0014 & 0.00073 \\
\hline
\end{tabular}




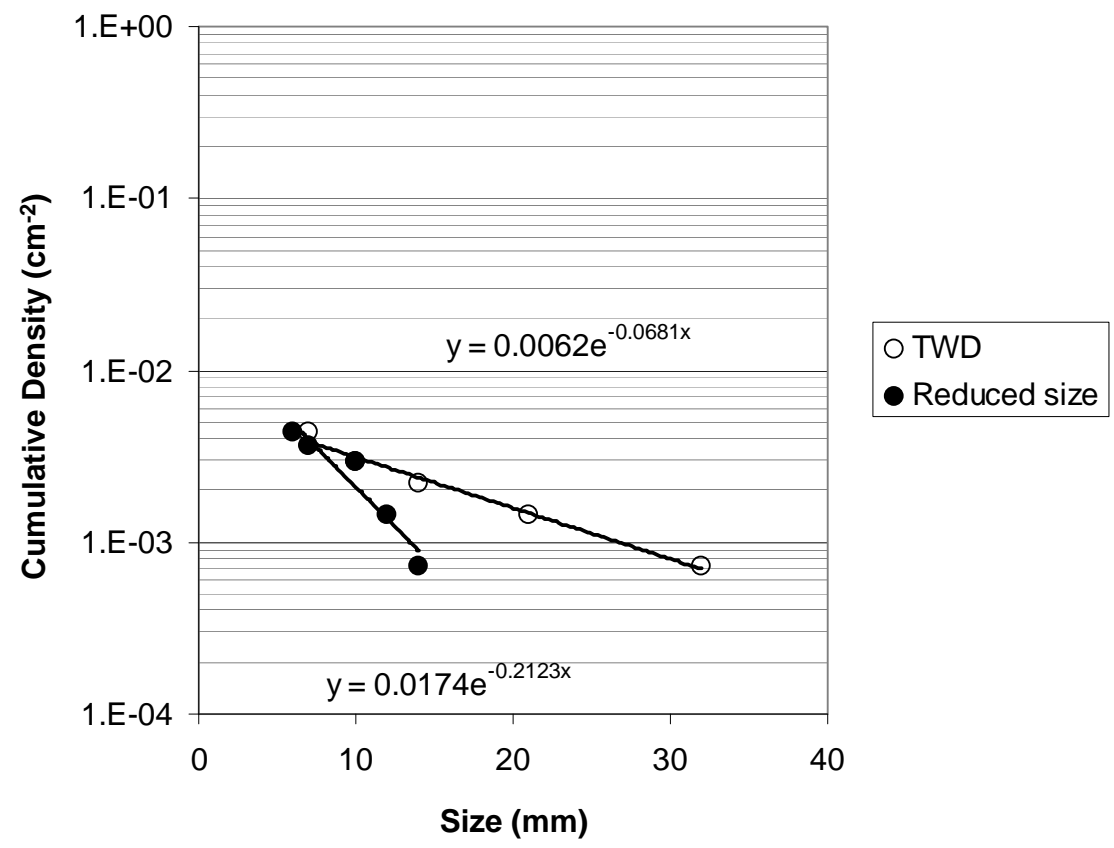

Figure 5.1 Through-Wall Dimension and Reduced Size Distribution Based on Fracture Mechanics for Flaws in Repairs in Seam Welds of Shoreham Reactor Pressure Vessel

\subsection{Validated Flaw Density in PVRUF Reactor Pressure Vessel Repairs}

The PVRUF reactor pressure vessel specimens contained one repair to a seam weld. Table 5.3 shows the through-wall dimension distribution for the seven flaws found. The through-wall dimension is the maximum extent of the flaw along the vessel through-wall axis. Table 5.4 shows the reduced throughwall size for the seven flaws. The reduced through-wall size, as described in Section 4.2, is the dimension of the minor axis of the flaw. Figure 5.2 charts the through-wall dimension and reduced size distribution for flaws in repairs in seam welds of the PVRUF reactor pressure vessel specimens.

Table 5.3 Through-Wall Dimension Distribution for Flaws in PVRUF Repairs

\begin{tabular}{||l|l|l|l||}
\hline Through-Wall Dimension & $\mathbf{5 . 5}(\mathbf{m m})$ & $\mathbf{1 1 . 5} \mathbf{( m m )}$ & $\mathbf{1 7 . 5}(\mathbf{m m})$ \\
\hline Frequency & 5 & 1 & 1 \\
\hline Cum. Freq. & 7 & 2 & 1 \\
\hline Density $\left(\mathrm{cm}^{-2}\right)$ & 0.0034 & 0.00099 & 0.00049 \\
\hline
\end{tabular}

Table 5.4 Reduced Through-Wall Size Distribution for Flaws in PVRUF Repairs

\begin{tabular}{||l|l|l|l||}
\hline Through-Wall Dimension & $\mathbf{2 . 5}(\mathbf{m m})$ & $\mathbf{5 . 5}(\mathbf{m m})$ & $\mathbf{1 7}(\mathbf{m m})$ \\
\hline Frequency & 1 & 1 & 2 \\
\hline Cum. Freq. & 7 & 2 & 1 \\
\hline Density $\left(\mathrm{cm}^{-2}\right)$ & 0.0034 & 0.0030 & 0.00049 \\
\hline
\end{tabular}




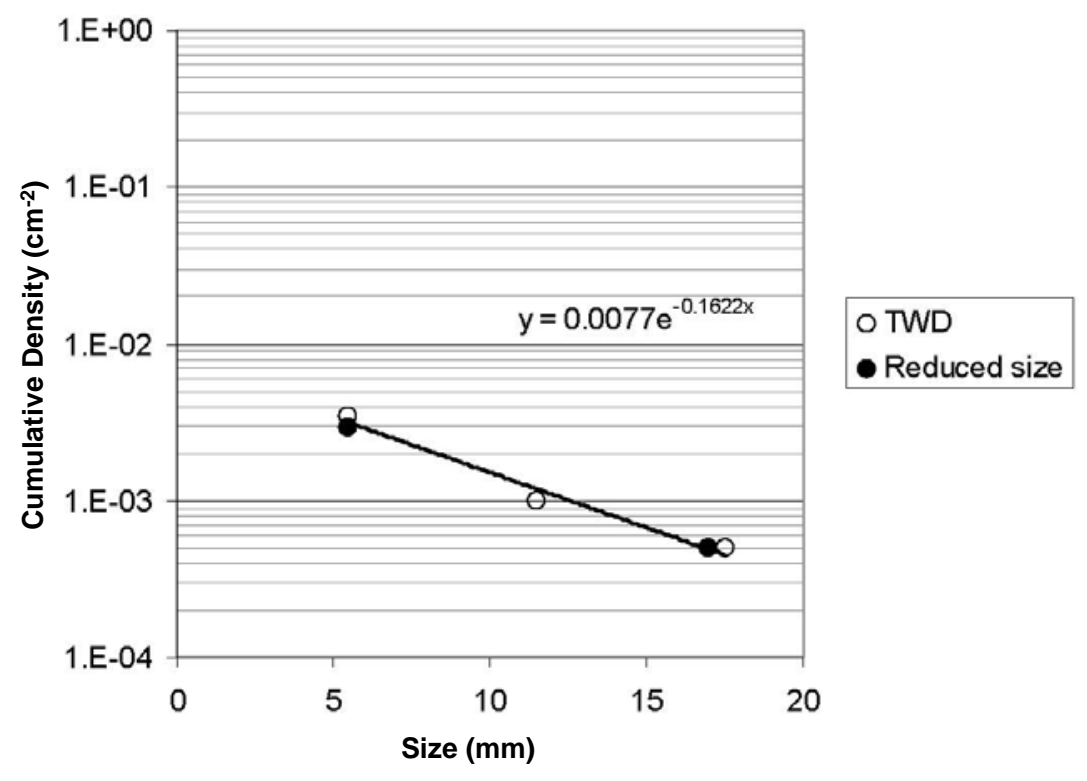

Figure 5.2 Through-Wall Dimension and Reduced Size Distribution Based on Fracture Mechanics Considerations for Flaws in Repairs in Seam Welds of PVRUF Reactor Pressure Vessel

\subsection{Validated Flaw Density in Hope Creek Unit 2 Reactor Pressure Vessel}

PNNL analyzed the fabrication flaw density and distribution in the repairs found in a Hope Creek Unit 2 RPV specimen. This section contains the validation results for the flaws in weld preparation surface repairs and repairs to a weld seam. Results are presented in separate charts of the flaws in the individual repairs and then summarized in a chart that compares the two repair types.

Seam repair A was a large repair, $11.4 \mathrm{~cm}$ through-wall, and completely contained in the PNNL specimen. Both repair cavity ends were carefully examined for flaws. Large flaws were not found on the repair cavity ends. Figure 5.3 gives the validated and unvalidated flaw distribution in seam BE repair A from the Hope Creek Unit 2 RPV. The validation did not change the flaw distribution as much as in the other repairs. Seam repair B was merged with seam repair A according to the construction records.

Seam repair C was a large repair, $12.1 \mathrm{~cm}$ through-wall, but only one end of it was contained in the PNNL specimen. Large flaws were found on the repair cavity ends in the PNNL specimen. Tables 5.7 and 5.8 provide the unvalidated and validated through-wall dimension distribution for seam repair C. Figure 5.4 shows validated and unvalidated flaw distribution in Hope Creek Unit 2 RPV seam BE repair C. The validation lowered the flaw density by $30 \%$.

Weld preparation surface repair $\mathrm{C}$ was a relatively shallow repair and difficult to distinguish from the seam weld fusion line. (Weld preparation surface repairs A and B were not in the PNNL specimen). Tables 5.9 and 5.10 provide the unvalidated and validated through-wall dimension distribution for weld preparation surface repair C. Figure 5.5 gives the validated and unvalidated flaw distribution in Hope Creek Unit 2 RPV weld preparation surface repair C on base metal piece 22-2 for seam BE. The validation did not find flaws larger than $10 \mathrm{~mm}$. 
Weld preparation surface repair D was a relatively deep repair and easily distinguished from the seam weld fusion line. Tables 5.11 and 5.12 provide the unvalidated and validated through-wall dimension distribution for weld preparation surface repair D. Figure 5.6 shows validated and unvalidated flaw distribution in Hope Creek Unit 2 RPV weld prep surface repair D on base metal piece 22-2 for seam BE. The validation did not find flaws larger than $10 \mathrm{~mm}$.

Weld preparation surface repair E was a relatively deep repair and easily distinguished from the seam weld fusion line. Tables 5.13 and 5.14 provide the unvalidated and validated through-wall dimension distribution for weld preparation surface repair E. Figure 5.7 gives validated and unvalidated flaw distribution in Hope Creek Unit 2 RPV weld prep surface repair E on base metal piece 22-2 for seam BE.

Tables 5.15 and 5.16 provide the validated through-wall dimension distribution for weld preparation surface repairs and seam repairs. Figure 5.8 gives validated cumulative flaw densities for weld seam repairs and weld preparation surface repairs in the Hope Creek Unit 2 RPV. The slope parameter, $\beta$, is the same to one significant figure at $0.4 \mathrm{~mm}^{-1}$. The density parameter, $\alpha$, differs by a factor of two.

Table 5.5 Unvalidated Through-Wall Dimension Distribution for Flaws in Hope Creek 2 Seam Repair A

\begin{tabular}{||l|c|c|l|l|l||}
\hline Through-Wall Dimension & $\mathbf{3}(\mathbf{m m})$ & $\mathbf{4}(\mathbf{m m})$ & $\mathbf{5}(\mathbf{m m})$ & $\mathbf{6}(\mathbf{m m})$ & $\mathbf{7}(\mathbf{m m})$ \\
\hline Frequency & 11 & 21 & 2 & 1 & 2 \\
\hline Cum. Freq. & 37 & 26 & 5 & 3 & 2 \\
\hline Density $\left(\mathrm{cm}^{-2}\right)$ & 0.056 & 0.039 & 0.0075 & 0.0045 & 0.0030 \\
\hline \hline
\end{tabular}

Table 5.6 Validated Through-Wall Dimension Distribution for Flaws in Hope Creek 2 Seam Repair A

\begin{tabular}{||l|c|c|c|c||}
\hline Through-Wall Dimension & $\mathbf{3 ( m m )}$ & $\mathbf{4}(\mathbf{m m})$ & $\mathbf{5 ( m m )}$ & $\mathbf{6 ~ ( m m )}$ \\
\hline Frequency & 6 & 16 & 6 & 2 \\
\hline Cum. Freq. & 30 & 24 & 8 & 2 \\
\hline Density $\left(\mathrm{cm}^{-2}\right)$ & 0.045 & 0.036 & 0.012 & 0.0030 \\
\hline
\end{tabular}




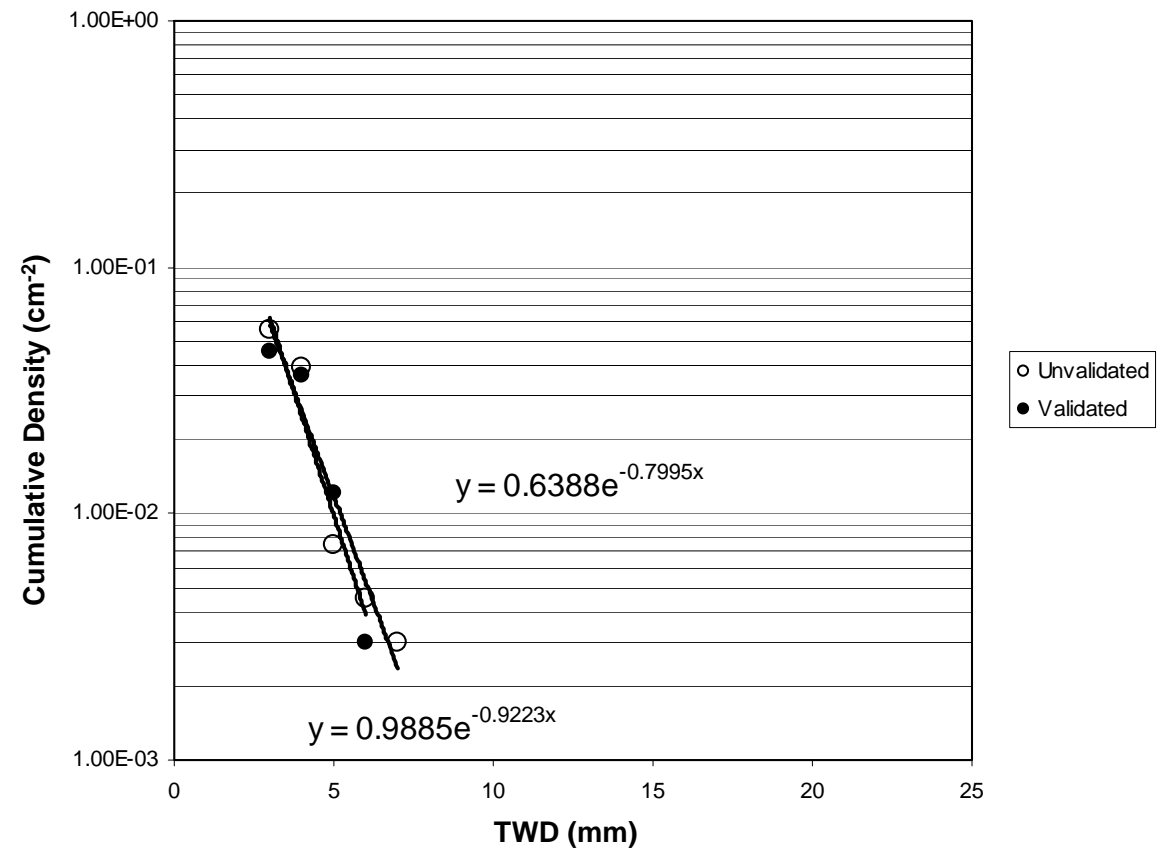

Figure 5.3 Validated and Unvalidated Through-Wall Size Distribution for Flaws in Seam Weld Repair A for Seam BE in Hope Creek Unit 2 Reactor Pressure Vessel

Table 5.7 Unvalidated Through-Wall Dimension Distribution for Flaws in Hope Creek 2 Seam Repair C

\begin{tabular}{||l|c|c|c|c|c|c|c||}
\hline $\begin{array}{c}\text { Through-Wall } \\
\text { Dimension }\end{array}$ & $\begin{array}{c}\mathbf{3} \\
\mathbf{( m m )}\end{array}$ & $\begin{array}{c}\mathbf{4} \\
\mathbf{( m m )}\end{array}$ & $\begin{array}{c}\mathbf{7} \\
\mathbf{( m m})\end{array}$ & $\begin{array}{c}\mathbf{9} \\
\mathbf{( m m})\end{array}$ & $\begin{array}{c}\mathbf{1 0} \\
\mathbf{( m m}\end{array}$ & $\begin{array}{c}\mathbf{1 2} \\
\mathbf{( m m})\end{array}$ & $\begin{array}{c}\mathbf{1 4} \\
\mathbf{( m m})\end{array}$ \\
\hline Frequency & 3 & 9 & 3 & 2 & 2 & 1 & 1 \\
\hline Cum. Freq. & 21 & 18 & 9 & 6 & 4 & 2 & 1 \\
\hline Density $\left(\mathrm{cm}^{-2}\right)$ & 0.080 & 0.068 & 0.034 & 0.023 & 0.015 & 0.0076 & 0.0038 \\
\hline
\end{tabular}

Table 5.8 Validated Through-Wall Dimension Distribution for Flaws in Hope Creek 2 Seam Repair C

\begin{tabular}{||l|c|c|c|c|c|c|c||}
\hline $\begin{array}{c}\text { Through-Wall } \\
\text { Dimension }\end{array}$ & $\begin{array}{c}\mathbf{2} \\
\mathbf{( m m )}\end{array}$ & $\begin{array}{c}\mathbf{3} \\
\mathbf{( m m )}\end{array}$ & $\begin{array}{c}\mathbf{4} \\
\mathbf{( m m )}\end{array}$ & $\begin{array}{c}\mathbf{5} \\
\mathbf{( m m )}\end{array}$ & $\begin{array}{c}\mathbf{9} \\
\mathbf{( m m})\end{array}$ & $\begin{array}{c}\mathbf{1 0} \\
\mathbf{( m m})\end{array}$ & $\begin{array}{c}\mathbf{1 1} \\
\mathbf{( m m})\end{array}$ \\
\hline Frequency & 2 & 9 & 4 & 2 & 2 & 1 & 1 \\
\hline Cum. Freq. & 21 & 19 & 10 & 6 & 4 & 2 & 1 \\
\hline Density $\left(\mathrm{cm}^{-2}\right)$ & 0.080 & 0.072 & 0.038 & 0.023 & 0.015 & 0.0076 & 0.0038 \\
\hline
\end{tabular}




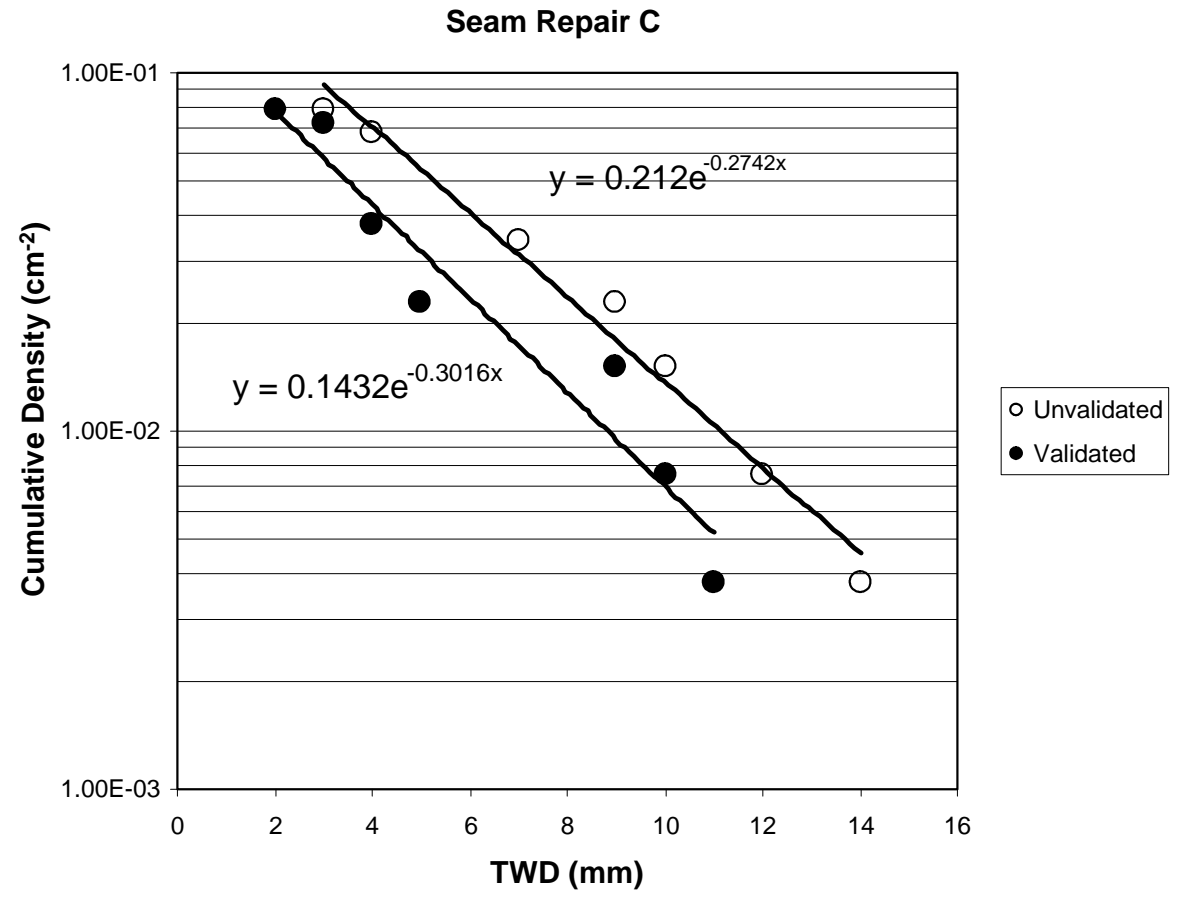

Figure 5.4 Validated and Unvalidated Through-Wall Size Distribution for Flaws in Seam Weld Repair C for Seam BE in Hope Creek Unit 2 Reactor Pressure Vessel

Table 5.9 Unvalidated Through-Wall Dimension Distribution for Flaws in Hope Creek 2 Weld Preparation Surface Repair C

\begin{tabular}{||l|c|c|c|c|l|l|l|l||}
\hline $\begin{array}{c}\text { Through-Wall } \\
\text { Dimension }\end{array}$ & $\begin{array}{c}\mathbf{3} \\
(\mathbf{m m})\end{array}$ & $\begin{array}{c}\mathbf{4} \\
\mathbf{( m m )}\end{array}$ & $\begin{array}{c}\mathbf{6} \\
\mathbf{( m m})\end{array}$ & $\begin{array}{c}\mathbf{7} \\
\mathbf{( m m})\end{array}$ & $\begin{array}{c}\mathbf{1 0} \\
\mathbf{( m m )}\end{array}$ & $\begin{array}{c}\mathbf{1 1} \\
\mathbf{( m m})\end{array}$ & $\begin{array}{c}\mathbf{1 3} \\
\mathbf{( m m})\end{array}$ & $\begin{array}{c}\mathbf{2 2} \\
\mathbf{( m m})\end{array}$ \\
\hline Frequency & 1 & 5 & 1 & 1 & 1 & 1 & 1 & 1 \\
\hline Cum. Freq. & 12 & 11 & 6 & 5 & 4 & 3 & 2 & 1 \\
\hline Density $\left(\mathrm{cm}^{-2}\right)$ & 0.074 & 0.068 & 0.037 & 0.031 & 0.025 & 0.019 & 0.012 & 0.0062 \\
\hline
\end{tabular}

Table 5.10 Validated Through-Wall Dimension Distribution for Flaws in Hope Creek 2 Weld Preparation Surface Repair C

\begin{tabular}{|l|c|c|l|l|l|l||}
\hline $\begin{array}{c}\text { Through-Wall } \\
\text { Dimension }\end{array}$ & $\begin{array}{c}\mathbf{3} \\
(\mathbf{m m})\end{array}$ & $\begin{array}{c}\mathbf{4} \\
\mathbf{( m m})\end{array}$ & $\begin{array}{c}\mathbf{5} \\
\mathbf{( m m )}\end{array}$ & $\begin{array}{c}\mathbf{6} \\
(\mathbf{m m})\end{array}$ & $\begin{array}{c}\mathbf{8} \\
(\mathbf{m m})\end{array}$ & $\begin{array}{c}\mathbf{1 0} \\
(\mathbf{m m})\end{array}$ \\
\hline Frequency & 2 & 2 & 2 & 2 & 3 & 2 \\
\hline Cum. Freq. & 13 & 11 & 9 & 7 & 5 & 2 \\
\hline Density $\left(\mathrm{cm}^{-2}\right)$ & 0.081 & 0.068 & 0.056 & 0.043 & 0.031 & 0.012 \\
\hline
\end{tabular}




\section{Weld Prep Repair C}

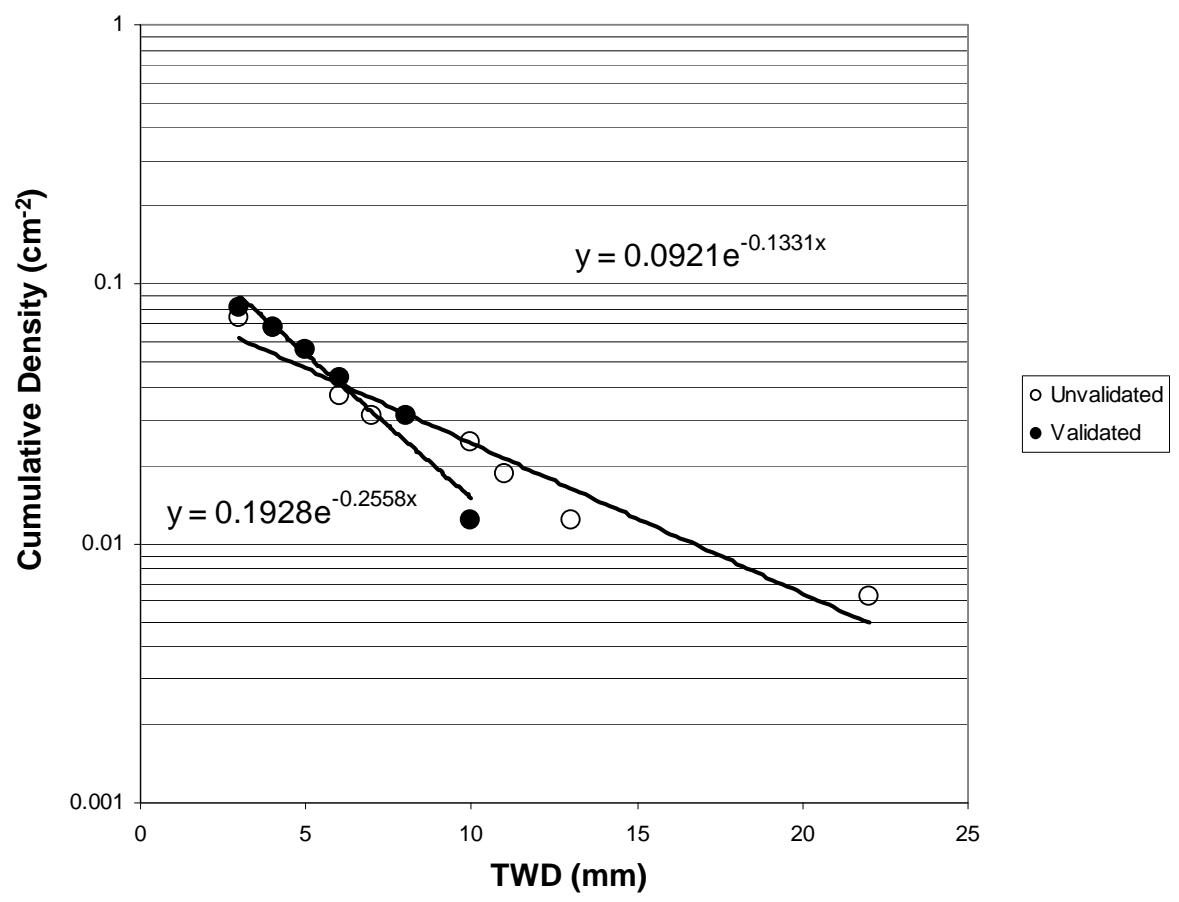

Figure 5.5 Validated and Unvalidated Through-Wall Size Distribution for Flaws in Weld Preparation Surface Repair C on Base Metal Piece 22-2 for Seam BE in Hope Creek Unit 2 Reactor Pressure Vessel

Table 5.11 Unvalidated Through-Wall Dimension Distribution for Flaws in Hope Creek 2 Weld Preparation Surface Repair D

\begin{tabular}{||l|c|c|l|l|l||}
\hline Through-Wall Dimension & $\mathbf{3}(\mathbf{m m})$ & $\mathbf{4}(\mathbf{m m})$ & $\mathbf{7}(\mathbf{m m})$ & $\mathbf{1 0}(\mathbf{m m})$ & $\mathbf{1 4}(\mathbf{m m})$ \\
\hline Frequency & 2 & 4 & 2 & 1 & 1 \\
\hline Cum. Freq. & 10 & 8 & 4 & 2 & 1 \\
\hline Density $\left(\mathrm{cm}^{-2}\right)$ & 0.10 & 0.084 & 0.042 & 0.021 & 0.010 \\
\hline \hline
\end{tabular}

Table 5.12 Validated Through-Wall Dimension Distribution for Flaws in Hope Creek 2 Weld Preparation Surface Repair D

\begin{tabular}{||l|c|c|l|l|l||}
\hline Through-Wall Dimension & $\mathbf{3}(\mathbf{m m})$ & $\mathbf{4}(\mathbf{m m})$ & $\mathbf{5}(\mathbf{m m})$ & $\mathbf{7}(\mathbf{m m})$ & $\mathbf{1 0}(\mathbf{m m})$ \\
\hline Frequency & 3 & 4 & 1 & 1 & 1 \\
\hline Cum. Freq. & 10 & 7 & 3 & 2 & 1 \\
\hline Density $\left(\mathrm{cm}^{-2}\right)$ & 0.10 & 0.073 & 0.031 & 0.021 & 0.010 \\
\hline
\end{tabular}


Weld Prep Repair D

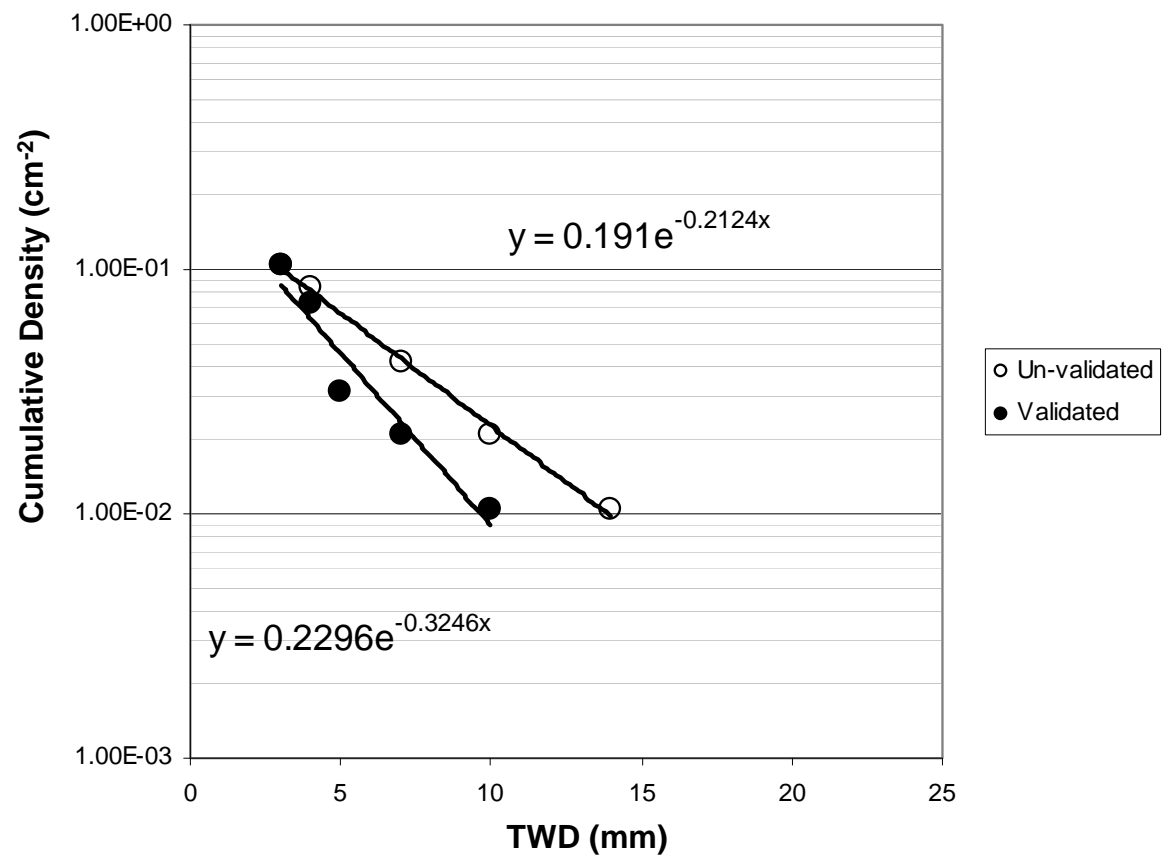

Figure 5.6 Validated and Unvalidated Through-Wall Size Distribution for Flaws in Weld Preparation Surface Repair D on Base Metal Piece 22-2 for Seam BE in Hope Creek Unit 2 Reactor Pressure Vessel

Table 5.13 Unvalidated Through-Wall Dimension Distribution for Flaws in Hope Creek 2 Weld Preparation Surface Repair E

\begin{tabular}{|l|c|c|l|l|l|l|l||}
\hline $\begin{array}{c}\text { Through-Wall } \\
\text { Dimension }\end{array}$ & $\begin{array}{c}\mathbf{3} \\
\mathbf{( m m )}\end{array}$ & $\begin{array}{c}\mathbf{4} \\
\mathbf{( m m})\end{array}$ & $\begin{array}{c}\mathbf{5} \\
\mathbf{( m m})\end{array}$ & $\begin{array}{c}\mathbf{6} \\
\mathbf{( m m})\end{array}$ & $\begin{array}{c}\mathbf{8} \\
\mathbf{( m m})\end{array}$ & $\begin{array}{c}\mathbf{1 3} \\
\mathbf{( m m})\end{array}$ & $\begin{array}{c}\mathbf{2 2} \\
\mathbf{( m m})\end{array}$ \\
\hline Frequency & 1 & 6 & 2 & 1 & 3 & 1 & 1 \\
\hline Cum. Freq. & 15 & 14 & 8 & 6 & 5 & 2 & 1 \\
\hline Density $\left(\mathrm{cm}^{-2}\right)$ & 0.14 & 0.13 & 0.074 & 0.056 & 0.046 & 0.018 & 0.0093 \\
\hline
\end{tabular}

Table 5.14 Validated Through-Wall Dimension Distribution for Flaws in Hope Creek 2 Weld Preparation Surface Repair E

\begin{tabular}{|l|c|c|l|l|l|l||}
\hline $\begin{array}{c}\text { Through-Wall } \\
\text { Dimension }\end{array}$ & $\begin{array}{c}\mathbf{3} \\
\mathbf{( m m )}\end{array}$ & $\begin{array}{c}\mathbf{4} \\
\mathbf{( m m )}\end{array}$ & $\begin{array}{c}\mathbf{5} \\
\mathbf{( m m})\end{array}$ & $\begin{array}{c}\mathbf{6} \\
\mathbf{( m m})\end{array}$ & $\begin{array}{c}\mathbf{8} \\
\mathbf{( m m})\end{array}$ & $\begin{array}{c}\mathbf{1 3} \\
\mathbf{( m m})\end{array}$ \\
\hline Frequency & 2 & 6 & 2 & 1 & 3 & 1 \\
\hline Cum. Freq. & 15 & 13 & 7 & 5 & 4 & 1 \\
\hline Density $\left(\mathrm{cm}^{-2}\right)$ & 0.14 & 0.12 & 0.065 & 0.046 & 0.037 & 0.00093 \\
\hline
\end{tabular}


Weld Prep Repair E

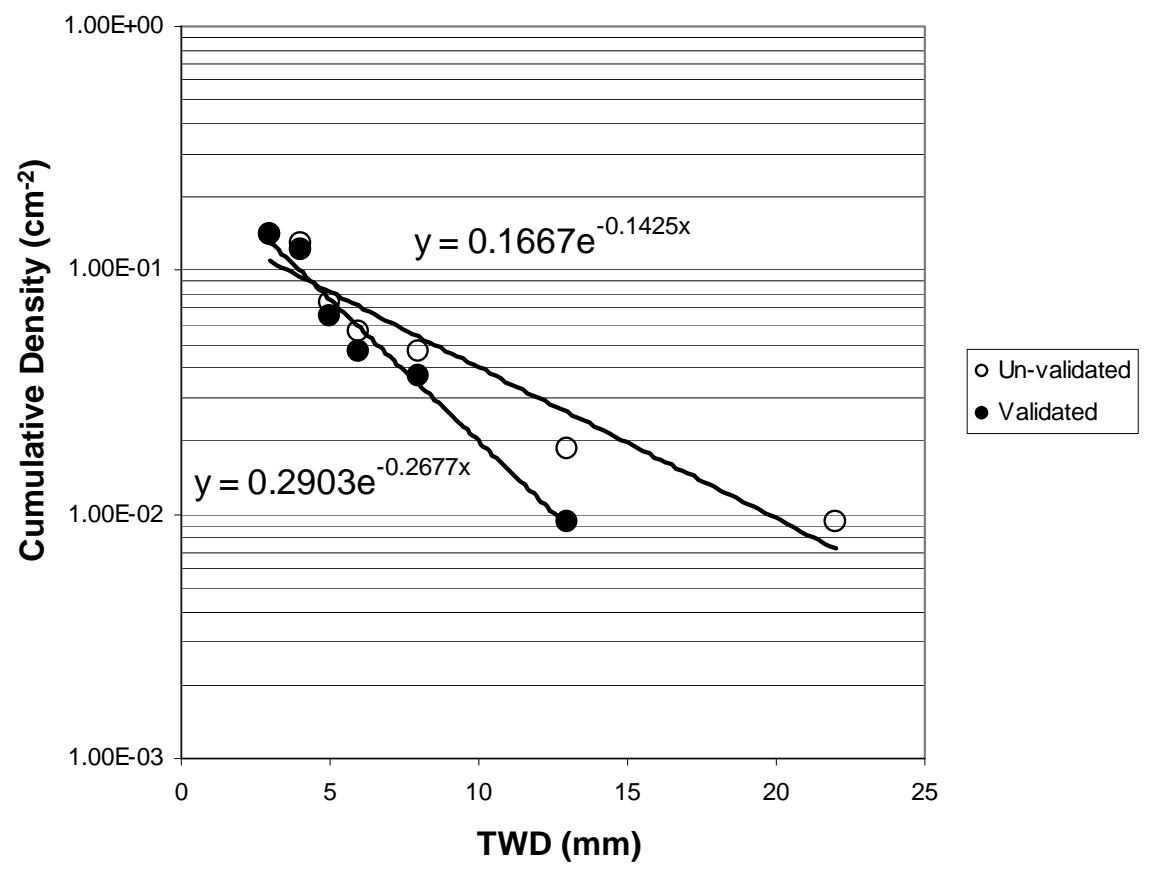

Figure 5.7 Validated and Unvalidated Through-Wall Size Distribution for Flaws in Weld Preparation Surface Repair E on Base Metal Piece 22-2 for Seam BE in Hope Creek Unit 2 Reactor Pressure Vessel

Table 5.15 Unvalidated Through-Wall Dimension Distribution for Flaws in Hope Creek 2 for Three Weld Preparation Surface Repairs

\begin{tabular}{||l|c|c|c|c|c|c|c|c||}
\hline $\begin{array}{c}\text { Through-Wall } \\
\text { Dimension }\end{array}$ & $\begin{array}{c}\mathbf{3} \\
(\mathbf{m m})\end{array}$ & $\begin{array}{c}\mathbf{4} \\
\mathbf{( m m )}\end{array}$ & $\begin{array}{c}\mathbf{5} \\
\mathbf{( m m})\end{array}$ & $\begin{array}{c}\mathbf{6} \\
\mathbf{( m m )}\end{array}$ & $\begin{array}{c}\mathbf{7} \\
\mathbf{( m m})\end{array}$ & $\begin{array}{c}\mathbf{8} \\
\mathbf{( m m})\end{array}$ & $\begin{array}{c}\mathbf{1 0} \\
(\mathbf{m m})\end{array}$ & $\begin{array}{c}\mathbf{1 3} \\
(\mathbf{m m})\end{array}$ \\
\hline Frequency & 7 & 12 & 5 & 3 & 1 & 6 & 3 & 1 \\
\hline Cum. Freq. & 38 & 31 & 19 & 14 & 11 & 10 & 4 & 1 \\
\hline Density $\left(\mathrm{cm}^{-2}\right)$ & 0.10 & 0.085 & 0.052 & 0.038 & 0.030 & 0.027 & 0.011 & 0.0027 \\
\hline
\end{tabular}

Table 5.16 Validated Through-Wall Dimension Distribution for Flaws in Hope Creek 2 for Two Seam Repairs

\begin{tabular}{|l|c|c|c|c|l|l|l|l|}
\hline $\begin{array}{c}\text { Through-Wall } \\
\text { Dimension }\end{array}$ & $\begin{array}{c}\mathbf{2} \\
\mathbf{( m m})\end{array}$ & $\begin{array}{c}\mathbf{3} \\
\mathbf{( m m})\end{array}$ & $\begin{array}{c}\mathbf{4} \\
\mathbf{( m m})\end{array}$ & $\begin{array}{c}\mathbf{5} \\
\mathbf{( m m})\end{array}$ & $\begin{array}{c}\mathbf{6} \\
\mathbf{( m m})\end{array}$ & $\begin{array}{c}\mathbf{9} \\
\mathbf{( m m})\end{array}$ & $\begin{array}{c}\mathbf{1 0} \\
\mathbf{( m m})\end{array}$ & $\begin{array}{c}\mathbf{1 1} \\
(\mathbf{m m})\end{array}$ \\
\hline Frequency & 2 & 15 & 20 & 8 & 2 & 2 & 1 & 1 \\
\hline Cum. Freq. & 51 & 49 & 34 & 14 & 6 & 4 & 2 & 1 \\
\hline Density $\left(\mathrm{cm}^{-2}\right)$ & 0.055 & 0.053 & 0.036 & 0.015 & 0.0064 & 0.0043 & 0.0021 & 0.0010 \\
\hline
\end{tabular}




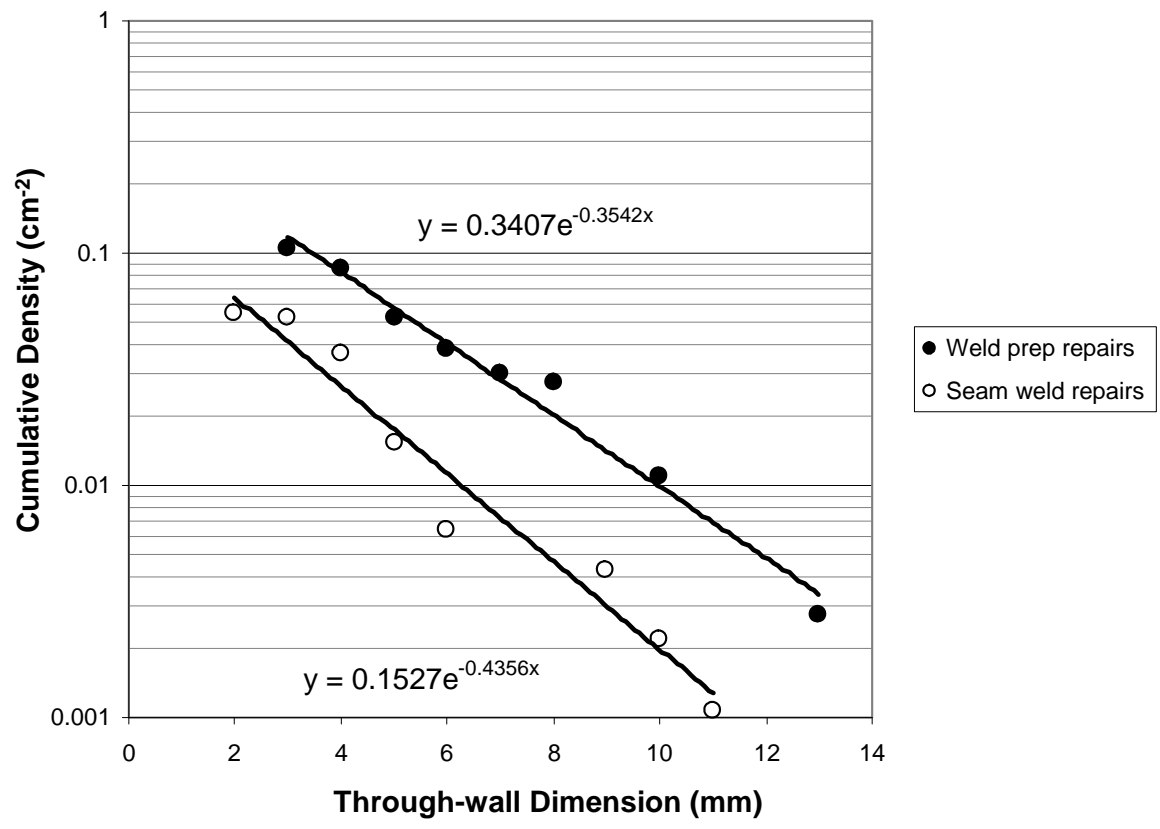

Figure 5.8 Validated Cumulative Through-Wall Size Distribution for Seam Weld Repairs and Weld Preparation Surface Repairs in the Hope Creek Unit 2 Reactor Pressure Vessel

\subsection{Repairs to Dissimilar Metal Welds of Piping}

Seven flaw indications were found in the repair metal of dissimilar metal weld specimen 12. Table 5.17 gives the density and unvalidated through-wall dimension distribution for the seven flaw indications found in the repair metal. Table 5.18 gives the validated density as a function of cumulative through-wall dimension. The length of the flaws in the repair metal was the same as their through-wall dimension. Figure 5.9 charts the validated and unvalidated cumulative through-wall size distribution for flaws in repairs in dissimilar metal welds of piping.

Table 5.17 Unvalidated Through-Wall Size Distribution for Flaws in Repairs

\begin{tabular}{||l|l|l|l|l||}
\hline Through-Wall Dimension & $\mathbf{2 . 4}(\mathbf{m m})$ & $\mathbf{4 . 4} \mathbf{( m m})$ & $\mathbf{7 . 9} \mathbf{( m m})$ & $\mathbf{1 0 . 4} \mathbf{( m m})$ \\
\hline Frequency & 4 & 1 & 1 & 1 \\
\hline Cum. Freq. & 7 & 3 & 2 & 1 \\
\hline Density $\left(\mathrm{cm}^{-2}\right)$ & 0.059 & 0.051 & 0.017 & 0.0084 \\
\hline
\end{tabular}

Table 5.18 Validated Through-Wall Size Distribution for Flaws in Repairs

\begin{tabular}{||l|l|l|l|l||}
\hline Through-Wall Dimension & $\mathbf{2 . 0}(\mathbf{m m})$ & $\mathbf{2 . 5} \mathbf{( m m})$ & $\mathbf{3 . 0} \mathbf{( m m})$ & $\mathbf{4 . 5}(\mathbf{m m})$ \\
\hline Frequency & 1 & 1 & 4 & 1 \\
\hline Cum. Freq. & 7 & 6 & 5 & 1 \\
\hline Density $\left(\mathrm{cm}^{-2}\right)$ & 0.059 & 0.051 & 0.042 & 0.0084 \\
\hline
\end{tabular}




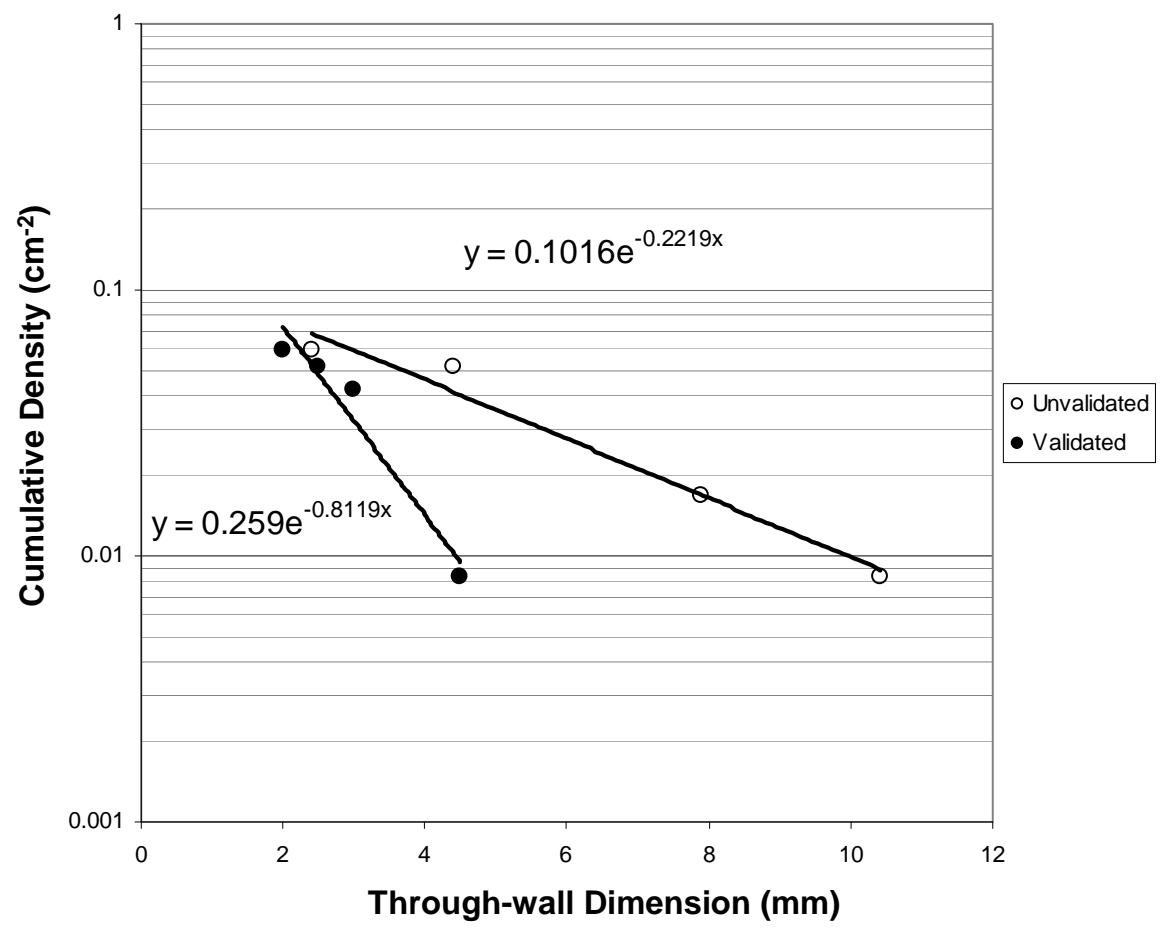

Figure 5.9 Validated and Unvalidated Cumulative Through-Wall Size Distribution for Flaws in Repairs in Dissimilar Metal Welds of Piping

\subsection{Repair Flaw Location Distribution}

The locations of the repair flaws in the repair cavity were analyzed for their depth location distribution. The data suggest a random distribution of the flaws with depth in the cavity.

The first chart, Figure 5.10, uses the repair flaw depth from the repair cavity surface and plots the cumulative fraction starting at the cavity surface and ending with the deepest flaw. The data points shown as open circles do not fall on a straight line with the other points. This is to be expected because some of the repair cavities were deeper than others.

The second chart, Figure 5.11, uses the repair flaw depth expressed as a fraction of the cavity depth and plots the cumulative fraction starting at the cavity surface and ending at 1.0. The chart does not show a depth dependence for the distribution of repair flaw locations. 


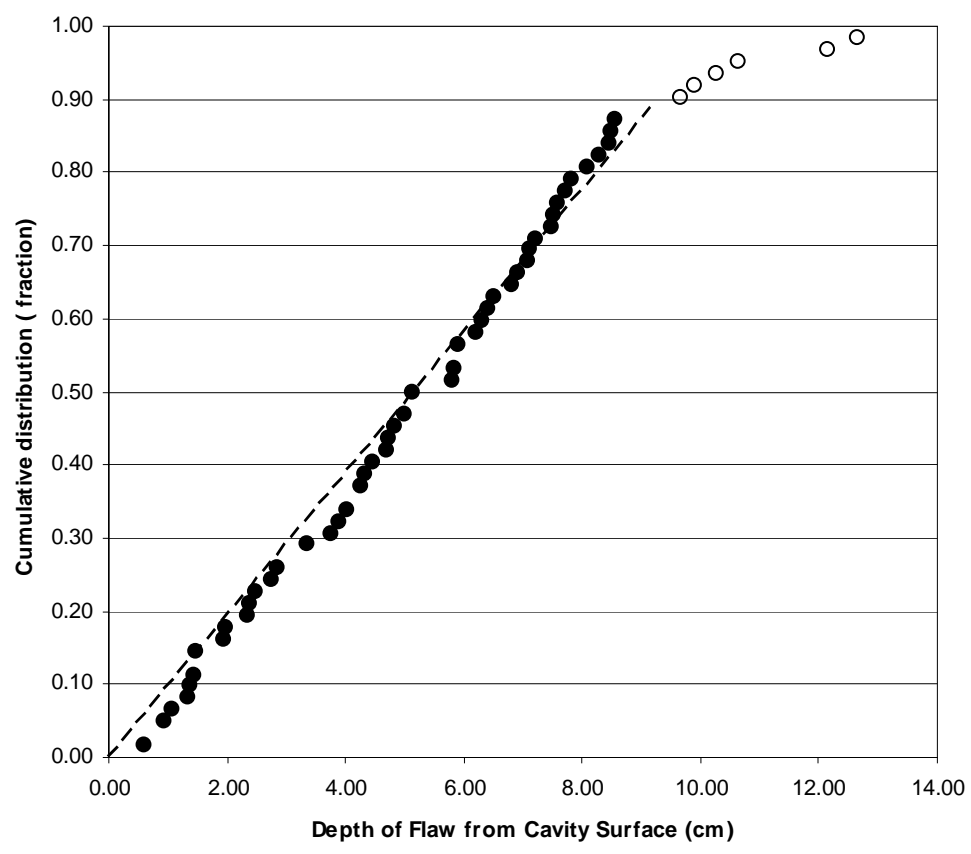

- All cavities o Deep portion of 2 cavities

Figure 5.10 Distribution of Repair Flaws Through the Cavity Depth in Centimeters from the Cavity Surface

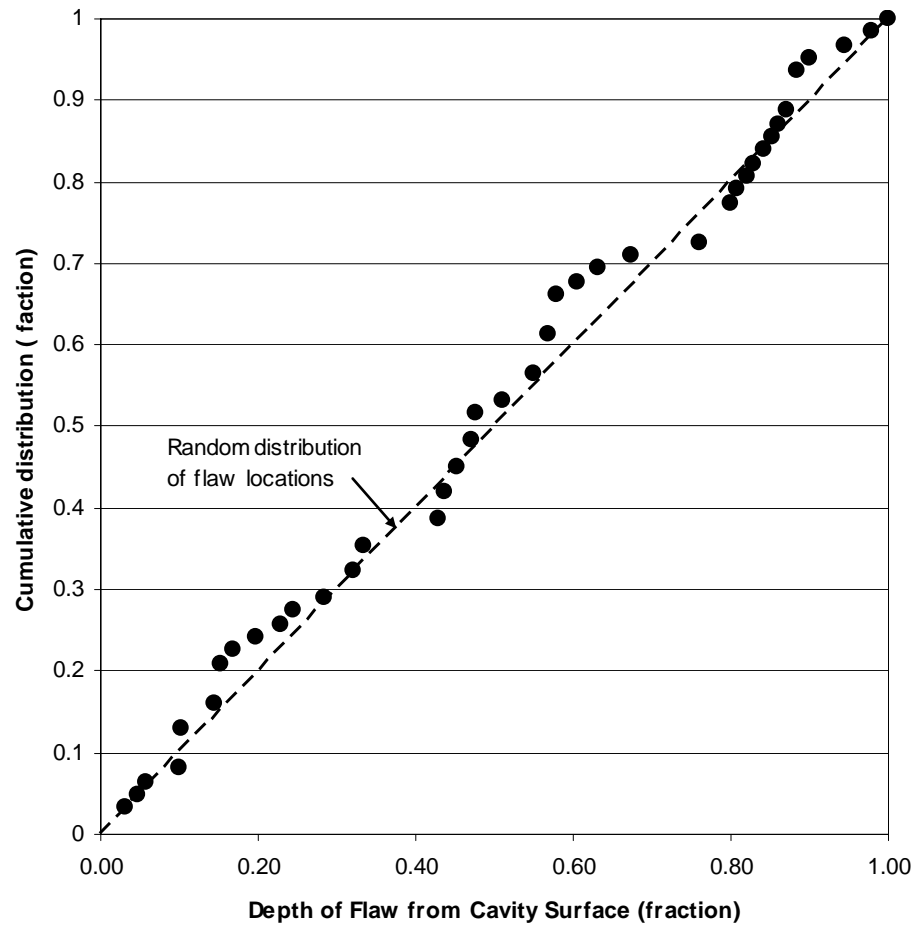

Figure 5.11 Distribution of Repair Flaws Through the Cavity as a Fraction of the Cavity Depth 


\subsection{Summary of Findings}

Conclusions can be drawn from the data extracted from the construction records and from the validated flaw density and distribution in the repair metal that was studied. Construction records recorded the repair locations and cavity dimensions. PNNL data on repair flaw morphology showed complex composition including cracks as part of a larger flaw. Separate size distributions can be estimated for individual vessel repairs, and those distributions are highly variable.

The defects reported in the construction records were found by documented NDE procedures or were visually apparent. PT found defects, mostly slag defects, sometimes through the cladding thickness. A factor of 10 difference in defect density was found between the Hope Creek Unit 2 vessel (manufactured in the early 1970s) and that of River Bend Unit 2 (manufactured in the late 1970s). The PVRUF vessel, a late-vintage vessel, had a defect density more like that of the River Bend Unit 2 RPV. RT and UT found defects of various kinds in the seam welds. Most of the reported defects- $80 \%$ in Hope Creek Unit 2 were found by RT. For defects greater than $3.5 \mathrm{~cm}$ in length, there is a difference of a factor of 10 between the two vessels. This indicates that the welding process improved and fewer defects were being created in the newer vessels.

PNNL analyzed the fabrication flaw density and distribution in the repairs found in a Hope Creek Unit 2 RPV specimen. Results are presented in separate charts of the flaws in the individual repairs and then summarized in a chart that compared the two repair types. A greater flaw density was observed in the weld preparation surface repairs when compared to seam weld repairs. The weld preparation surface repairs are embedded while the structural seam weld repairs connect to either the ID or the OD of the vessel. Metallographic analysis of one flaw on the end of seam weld is provided. Cracking was observed in the metallographic specimen.

The repairs that were found in a dissimilar metal weld did not have large flaws on the cavity ends as did the reactor pressure vessel repairs. One explanation for the difference is that the welding procedures used to make the repairs were significantly different-possibly the piping procedure required a repair cavity that allowed the weld pass to start and stop at the surface of pipe.

The repair flaws were found to be complex. Metallographic analysis of repair flaw specimens shows that the fabrication flaws are composed of a mixture of cracks, lack of fusion, contamination, and porosity. The repair flaws can repeat on the next weld pass. This phenomenon is of known interest to the modeling of welding flaws (Chapman and Simonen 1998).

PNNL's laboratory data acquired on repairs in weld segments was analyzed to determine the fabrication flaw density and size distribution. Weld segments from three reactor pressure vessels and one dissimilar metal weld piping section were found to contain weld repairs. The NDE inspections detected many fabrication flaws in the repairs, and the data were analyzed for density and distribution. An estimate of flaw density and distribution was made for five cases.

The results for through-wall size distribution are given in Figure 6.1. A parametric fit is made to the cumulative flaw size distribution, and the parameters are given in Table 6.1. The through-wall dimensions of repair flaws span a range extending from $2 \mathrm{~mm}$ to $17 \mathrm{~mm}$. For the five flaw distributions shown in Figure 6.1, significant differences can be seen-a factor of 10 difference in some cases. The 
distributions of flaws for the seam weld repairs from three vessels (the PVRUF, Shoreham, and Hope Creek Unit 2 repairs) should have similar slopes; the variability can be attributed to the small number of repairs examined. In Figure 6.1, the distribution of flaws for weld preparation surface repairs is shown to be higher than that of flaws in weld seam repairs. This is to be expected because the repair metal in this case contacts the midwall segregates in the base metal. The distribution of flaws in the repairs found in the three piping repairs spans a limited range, from $2 \mathrm{~mm}$ to $4 \mathrm{~mm}$.

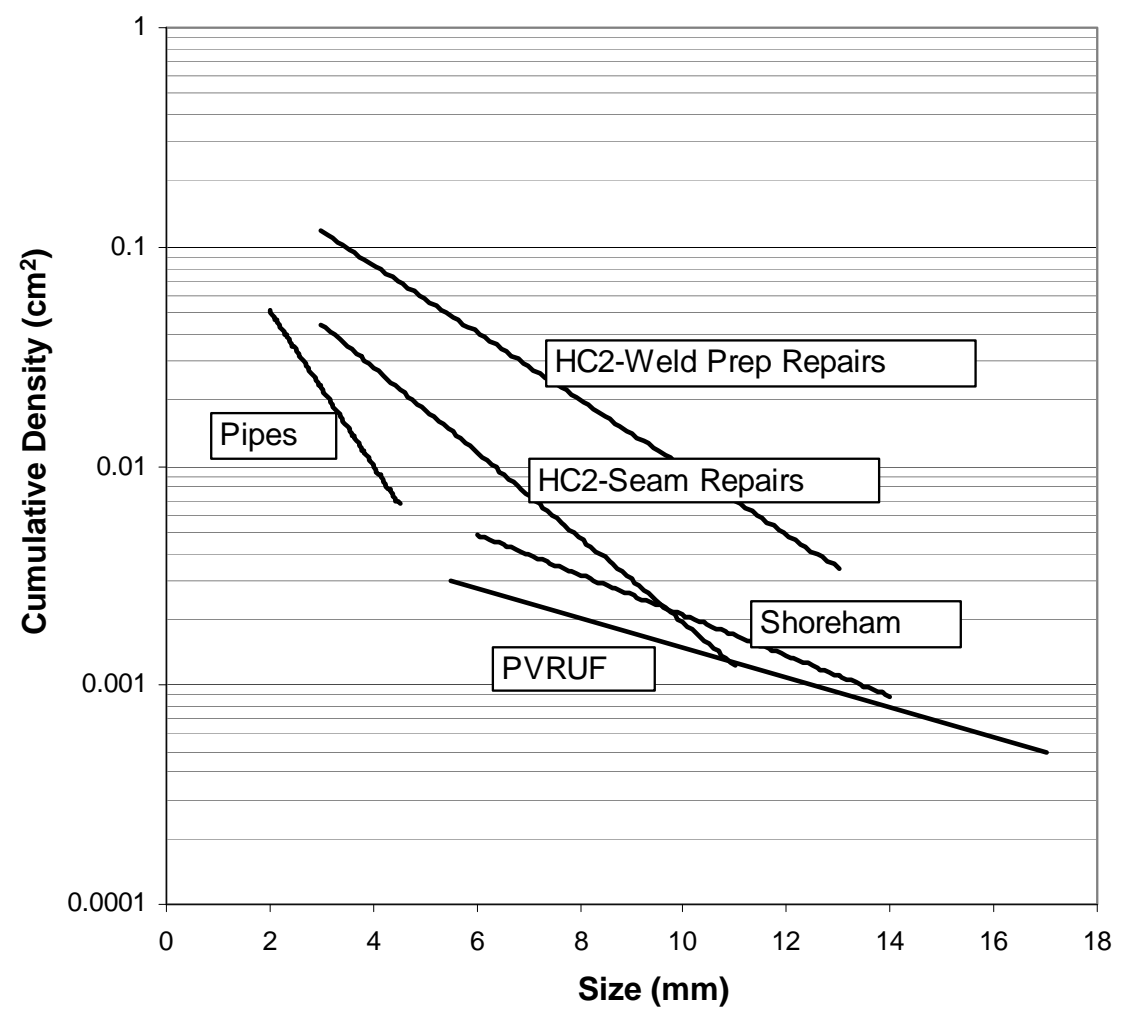

Figure 6.1 Comparison of Flaw Density and Through-Wall Size Distributions for Repair Flaws in Three Reactor Pressure Vessels and in Dissimilar Metal Welds of Piping

Table 6.1 Exponential Fit Results for Through-Wall Size

\begin{tabular}{|l|l|l|}
\hline & \multicolumn{1}{|c|}{$\boldsymbol{\alpha}$} & \multicolumn{1}{c|}{$\boldsymbol{\beta}$} \\
\hline Hope Creek 2 - Weld Prep. Repairs & $0.34 \mathrm{~cm}^{-2}$ & $0.35 \mathrm{~mm}^{-1}$ \\
\hline Hope Creek 2 - Seam Weld Repairs & $0.15 \mathrm{~cm}^{-2}$ & $0.44 \mathrm{~mm}^{-1}$ \\
\hline Shoreham - Seam Weld Repairs & $0.017 \mathrm{~cm}^{-2}$ & $0.21 \mathrm{~mm}^{-1}$ \\
\hline PVRUF - Seam Weld Repairs & $0.0077 \mathrm{~cm}^{-2}$ & $0.16 \mathrm{~mm}^{-1}$ \\
\hline Pipes - Dissimilar Metal Weld Repairs & $0.37 \mathrm{~cm}^{-2}$ & $0.22 \mathrm{~mm}^{-1}$ \\
\hline
\end{tabular}




\subsection{Future Work}

Additional work could be performed on extracting product form information from construction records, applying advanced NDE for detecting cracks, preparing changes to the ASME Code, and inspecting additional repair metal. Construction records have been shown to contain much useful information on the density and distribution of fabrication flaws and improved fabrication practice. Cracks in RPVs are difficult to detect and difficult to distinguish from other weld discontinuities. Current ASME Code requirements do not have any special requirements for repairs because the assumption is that the repairs are perfect (flaw-free weld metal). The flaw densities in repairs is shown to be highly variable; additional data could be obtained, especially for pipe weld repairs. 


\subsection{References}

American Society of Mechanical Engineers. 1998. "Section XI Rules for Inservice Inspection of Nuclear Power Plant Components.” In ASME Boiler and Pressure Vessel Code. American Society of Mechanical Engineers, New York.

American Welding Society, Inc. (AWS). 1984. Standard Welding Terms and Definitions, ANSI/AWS A3.0-85. American Welding Society, Inc., Miami, Florida.

Busse LJ, HD Collins, and SR Doctor. 1984. Review and Discussion of the Development of Synthetic Aperture Focusing Technique for Ultrasonic Testing, SAFT-UT. NUREG/CR-3625, PNL-4957, U.S. Nuclear Regulatory Commission, Washington, D.C.

Chapman V. 1993. "Simulation of Defects in Weld Construction.” In Pressure Vessel and Piping Conference, Reliability and Risk in Pressure Vessels and Piping, PVP-Vol. 251, pp. 81-89. American Society of Mechanical Engineers, New York.

Chapman OJV and FA Simonen. 1998. RR-PRODIGAL - A Model for Estimating the Probabilities of Defects in Reactor Pressure Vessel Welds. NUREG/CR-5505, PNNL-11898, U.S. Nuclear Regulatory Commission, Washington, D.C.

Crawford SL, GJ Schuster, AF Pardini, and SR Doctor. 2000. "Initial Studies in Developing Fabrication Flaw Rates for Base Metal of Pressure Vessels.” Presented to the $2^{\text {nd }}$ International Conference on NDE in Relation to Structural Integrity for Nuclear and Pressurized Components, May 24-26, 2000, New Orleans, Louisiana.

Dickson TL. 1994. FAVOR: A Fracture Mechanics Analysis Code for Nuclear Reactor Pressure Vessels, Release 9401. ORNL/NRC/LTR/94/1, Martin Marietta Energy Systems, Inc., Oak Ridge National Laboratory, Oak Ridge, Tennessee.

Doctor SR, GJ Schuster, LD Reid, and TE Hall. 1996. Real-Time 3-D SAFT-UT Evaluation and Validation. NUREG/CR-6344, PNNL-10571, U.S. Nuclear Regulatory Commission, Washington, D.C.

Doctor SR and GJ Schuster. 2001. "Destructive Validation Methodology and Results for the Characterization of Flaws in Nuclear Reactor Pressure Vessels.” Presented to the $3^{\text {rd }}$ International Conference of NDE in Relation to Structural Integrity for Nuclear and Pressurized Components, November 14-16, 2001, Seville, Spain.

Ekstrom P and J Wale. 1995. Crack Characterization for In-service Inspection Planning. SKI Report 95:70, Swedish Nuclear Power Inspectorate, Stockholm, Sweden.

Gao H and JR Rice. 1987. “Somewhat Circular Tensile Cracks.” International Journal of Fracture 33:155-174.

Hall TE, LD Reid, and SR Doctor. 1988. The SAFT-UT Real-Time Inspection System - Operational Principles and Implementation. NUREG/CR-5075, U.S. Nuclear Regulatory Commission, Washington, D.C. 
Jackson DA and L Abramson. 2000. Report on the Preliminary Results of the Expert Judgment Process for the Development of a Methodology for a Generalized Flaw Size and Distribution for Domestic Reactor Pressure Vessels. MEB-00-01, PRAB-00-01, U.S. Nuclear Regulatory Commission, Washington, D.C.

Jackson DA, SR Doctor, GJ Schuster, and FS Simonen. 2001. "Developing a Generalized Flaw Distribution for Reactor Pressure Vessels.” Nuclear Engineering and Design 208:123-131.

Kou S and Y Le. 1985. “Alternating Grain Orientation and Weld Solidification Cracking.” Metallurgical Transactions A 16A (10):1887-1896.

Marshall W. 1976. An Assessment of the Integrity of PWR Pressure Vessels, Summary Report. Report of a study group under the Chairmanship of Dr. Walter Marshall, CBE FRS, United Kingdom Atomic Energy Authority, London.

Marshall W. 1982. An Assessment of the Integrity of PWR Pressure Vessels, Summary Report. Second report of a study group under the Chairmanship of Dr. Walter Marshall, CBE FRS, United Kingdom Atomic Energy Authority, London.

Morgan-Warren EJ and MF Jordan. 1974. "A Quantitative Study of the Effect of Composition on Weld Solidification Cracking in Low-Alloy Steels.” Metals Technology 1:271-278.

Nichols RW and S Crutzen. 1988. Ultrasonic Inspection of Heavy Section Steel Components, The PISC 2 Final Report. Elsevier Science Publishing Co., Inc., New York.

Orynyak IV, DO Harris, and AV Kamenchuck. 2001. "The Practical Analysis of Somewhat Circular Tensile Cracks with Uniform Loading.” Submitted for publication (in English) in Journal of Ukrainian Material Science.

Pardini AF, GJ Schuster, SL Crawford, and SR Doctor. 2000. "Validation of Fabrication Flaws in Weld Metal from PVRUF." Presented to the $2^{\text {nd }}$ International Conference on NDE in Relation to Structural Integrity for Nuclear and Pressurized Components, May 24-26, 2000, New Orleans, Louisiana.

Pennel WE. 1989. Mission Survey for the Pressure Vessel Research Users' Facility (PVRUF).

NUREG/CR-5350, prepared by Oak Ridge National Laboratory, Oak Ridge, Tennessee, for the U.S.

Nuclear Regulatory Commission, Washington, D.C.

Rosinski ST, K Kietzman, and BJ Rassler. 1998. "Reactor Pressure Vessel Flaw Distribution Development.” Presented to the EPRI Reactor Pressure Vessel Inspection Conference, June 22-24, 1998, Santa Fe, New Mexico.

Schuster GJ, SR Doctor, and AF Pardini. 1997. "Validation of Reactor Pressure Vessel Fabrication Flaws.” Presented to the NDE Damage Assessment Workshop, October 6-7, 1997, La Jolla, California.

Schuster GJ, SR Doctor, and PG Heasler. 1998. Characterization of Flaws in U.S. Reactor Pressure Vessels: Density and Distribution of Flaw Indications in PVRUF. NUREG/CR-6471, Vol. 1, PNNL-11143, U.S. Nuclear Regulation Commission, Washington, D.C. 
Schuster GJ, SR Doctor, SL Crawford, and AF Pardini. 1999. Characterization of Flaws in U.S. Reactor Pressure Vessels: Density and Distribution of Flaw Indications in the Shoreham Vessel.

NUREG/CR-6471, Vol. 3, PNNL-11143, U.S. Nuclear Regulatory Commission, Washington, D.C.

Schuster GJ, SR Doctor, AF Pardini, and SL Crawford. 2000. Characterization of Flaws in U.S. Reactor Pressure Vessels: Validation of Flaw Density and Distribution in the Weld Metal of the PVRUF Vessel. NUREG/CR-6471, Vol. 2, PNNL-11143B, U.S. Nuclear Regulatory Commission, Washington, D.C.

Schuster GJ, SR Doctor, and LJ Bond. 2004. “A System for High-Resolution, Nondestructive, Ultrasonic Imaging of Weld Grains.” IEEE Transactions on Instrumentation and Measurement 53(6):1526-1532.

Simonen FA, KI Johnson, AM Liebetrau, DW Engel, and EP Simonen. 1986a. VISA-2 - A Computer Code for Predicting the Probability of Reactor Pressure Vessel Failure. NUREG/CR-4486, U.S. Nuclear Regulatory Commission, Washington, D.C.

Simonen FA, MR Garnich, EP Simonen, SH Bian, KK Nomura, WE Anderson, and LT Pedersen. 1986b. Reactor Pressure Vessel Failure Probability Following Through-Wall Cracks Due to Pressurized Thermal Shock Events. NUREG/CR-4483, PNL-5727, U.S. Nuclear Regulatory Commission, Washington, D.C.

Simonen FA and MA Khaleel. 1995. "A Model for Predicting Vessel Failure Probabilities Due to Fatigue Crack Growth.” In Fatigue and Fracture Mechanics in Pressure Vessels and Piping, PVP-Vol. 304, pp. 401-416. American Society of Mechanical Engineers, New York.

Simonen FA, SR Doctor, GJ Schuster, and TL Dickson. 2002. "Distribution of Fabrication Flaws in Reactor Pressure Vessels for Structural Integrity Evaluations.” Presented to the 2002 ASME Pressure Vessels and Piping Conference, August 5-9, 2002, Vancouver, British Columbia, Canada.

Thielsch H. 1965. Defects and Failures in Pressure Vessels and Piping. Reinhold Publishing Corp., New York.

White CL. 1990. “Interfacial Segregation Effects on Fusion Zone and HAZ Cracking.” Presented to Weldability of Materials, October 8-12, 1990, Detroit, Michigan. ASTM International, West Consohocken, Pennsylvania.

U.S. Nuclear Regulatory Commission (NRC). 1987. Format and Content of Plant-Specific Pressurized Thermal Shock Safety Analysis Reports for Pressurized Water Reactors. Regulatory Guide 1.154, U.S. Nuclear Regulatory Commission, Washington, D.C. 
8.4 
Appendix A

Metallography 


\section{Appendix A}

\section{Metallography}

This appendix provides the optical micrographs from the analysis of Specimen C2CC from the Hope Creek Unit 2 RPV. This specimen contained a flaw from the end of a repair to a seam weld in the vessel. All of the micrograph images acquired in the metallographic analysis of this flaw are included in this appendix except for those already documented in Section 4. In all images, the vessel through-wall dimension is oriented vertically.

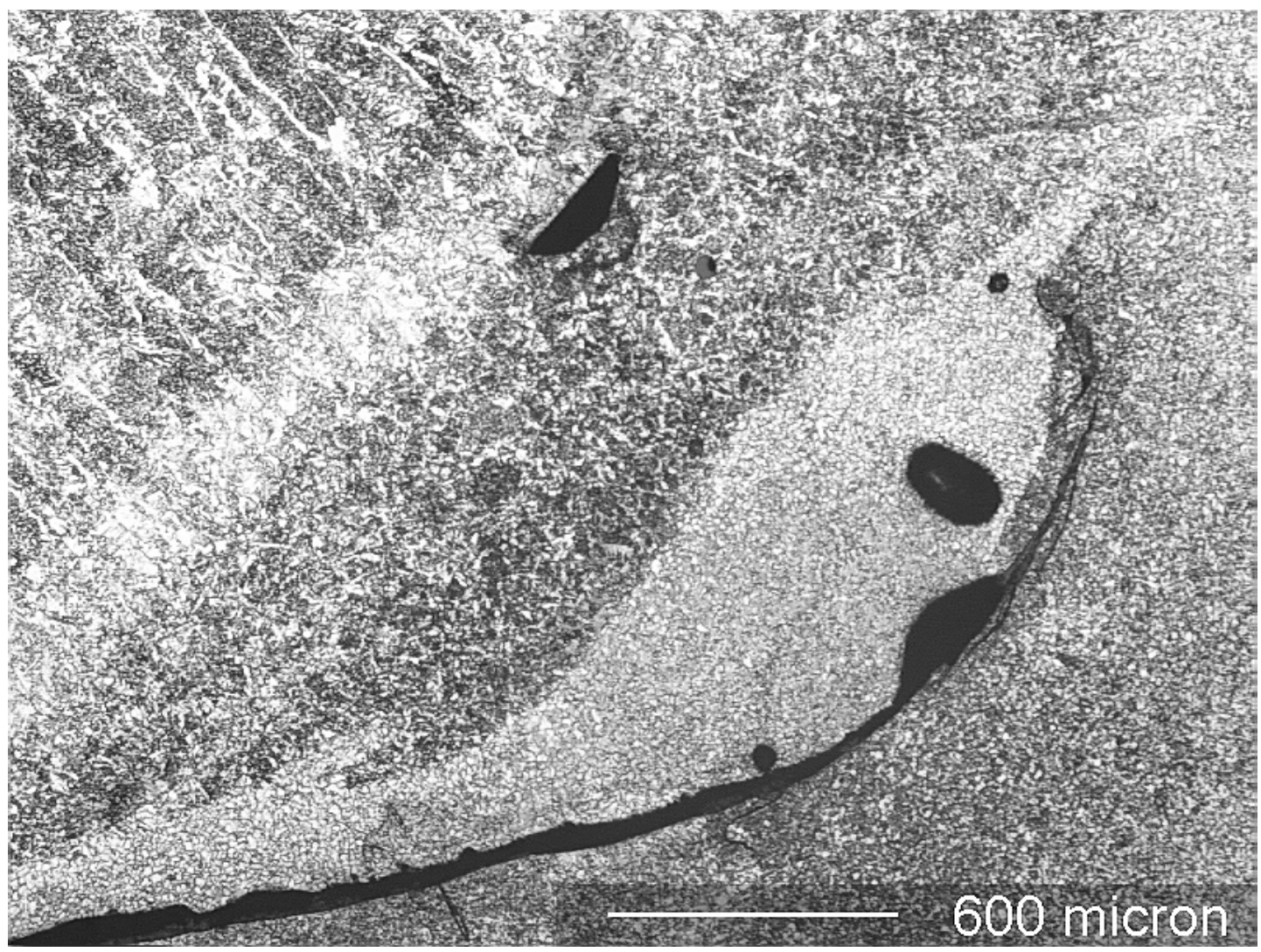

Figure A.1 Flaw C2CC on the End of Seam Repair C, as Polished and Etched. Flaw has properties of lack of fusion with weld solidification cracks. 


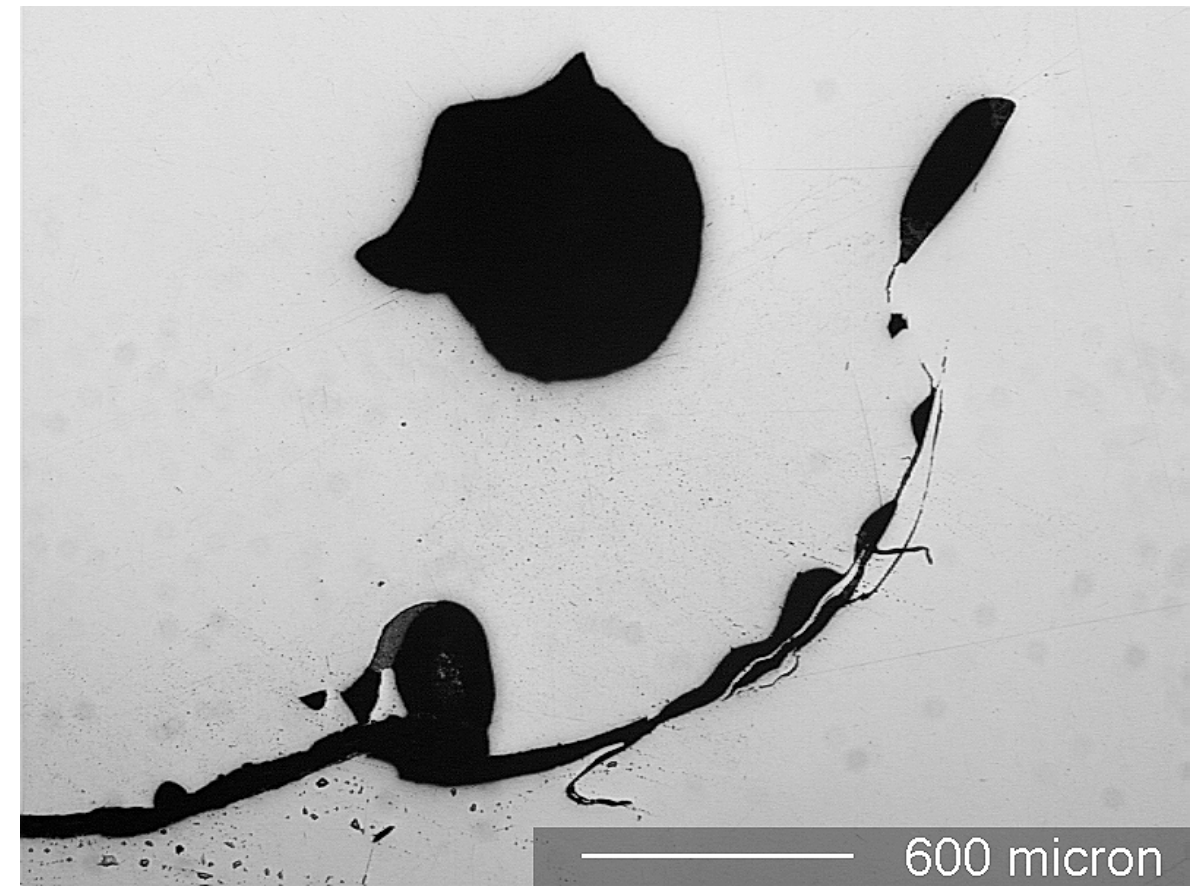

Figure A.2 Flaw C2CC on the End of Seam Repair C, as Machined

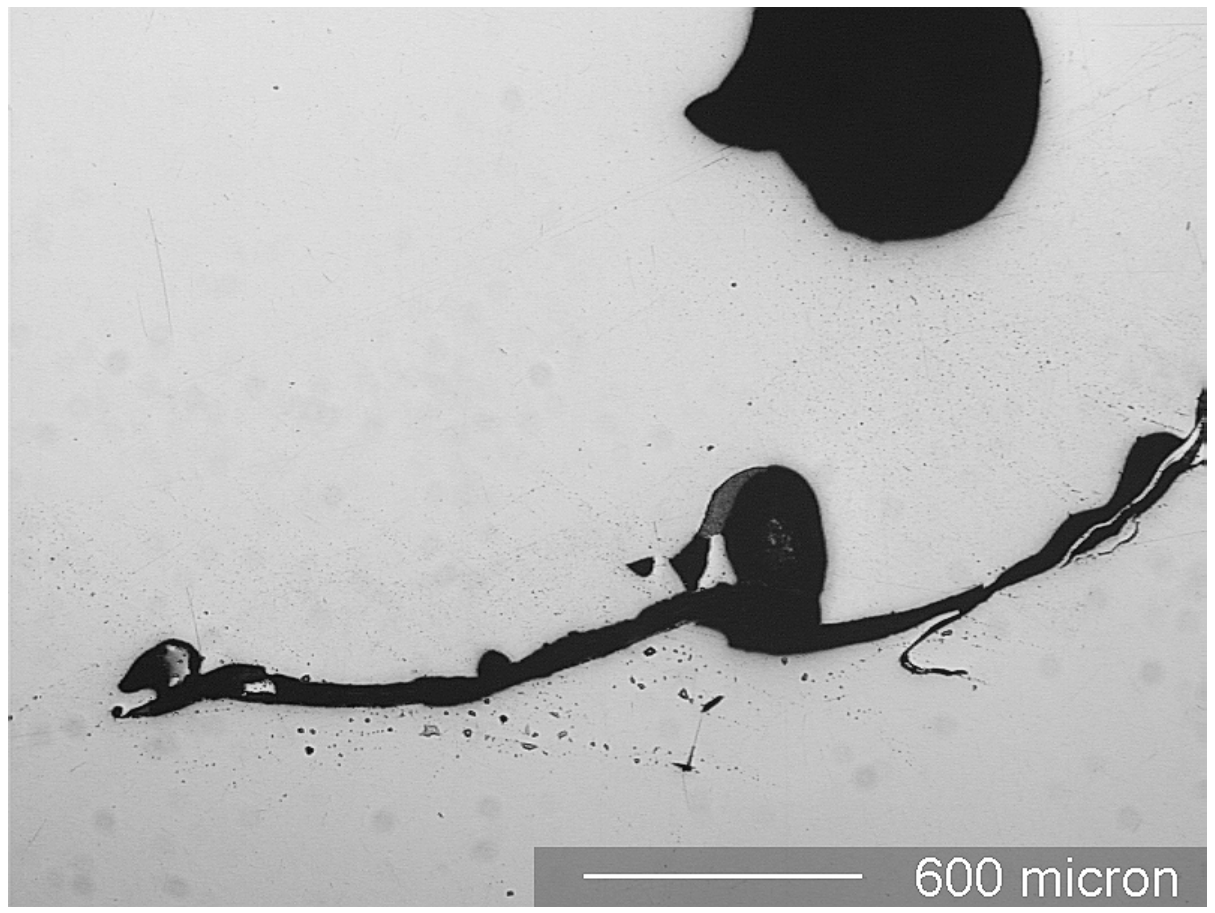

Figure A.3 Flaw C2CC on the End of Seam Repair C, as Machined 


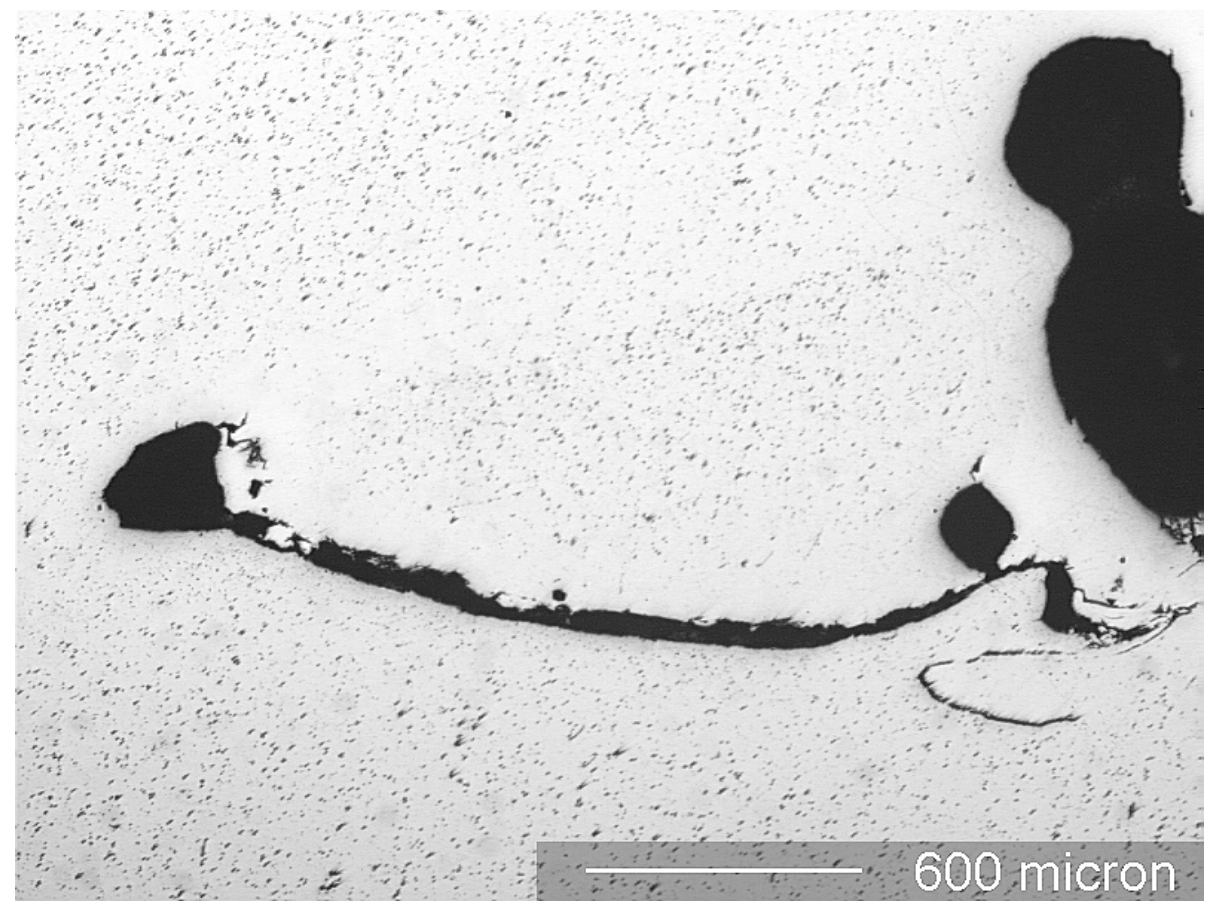

Figure A.4 Flaw C2CC on the End of Seam Repair C, as Machined

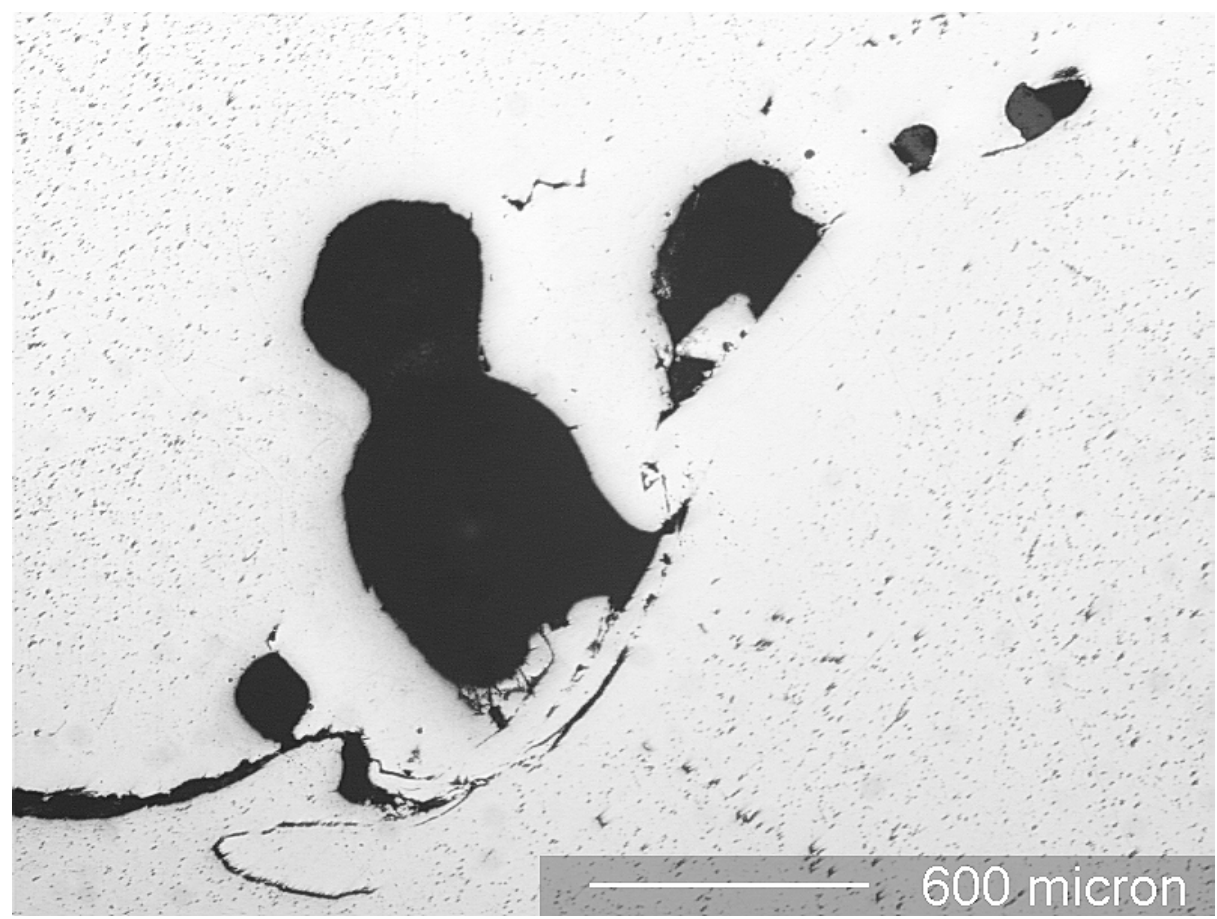

Figure A.5 Flaw C2CC on the End of Seam Repair C, as Machined 


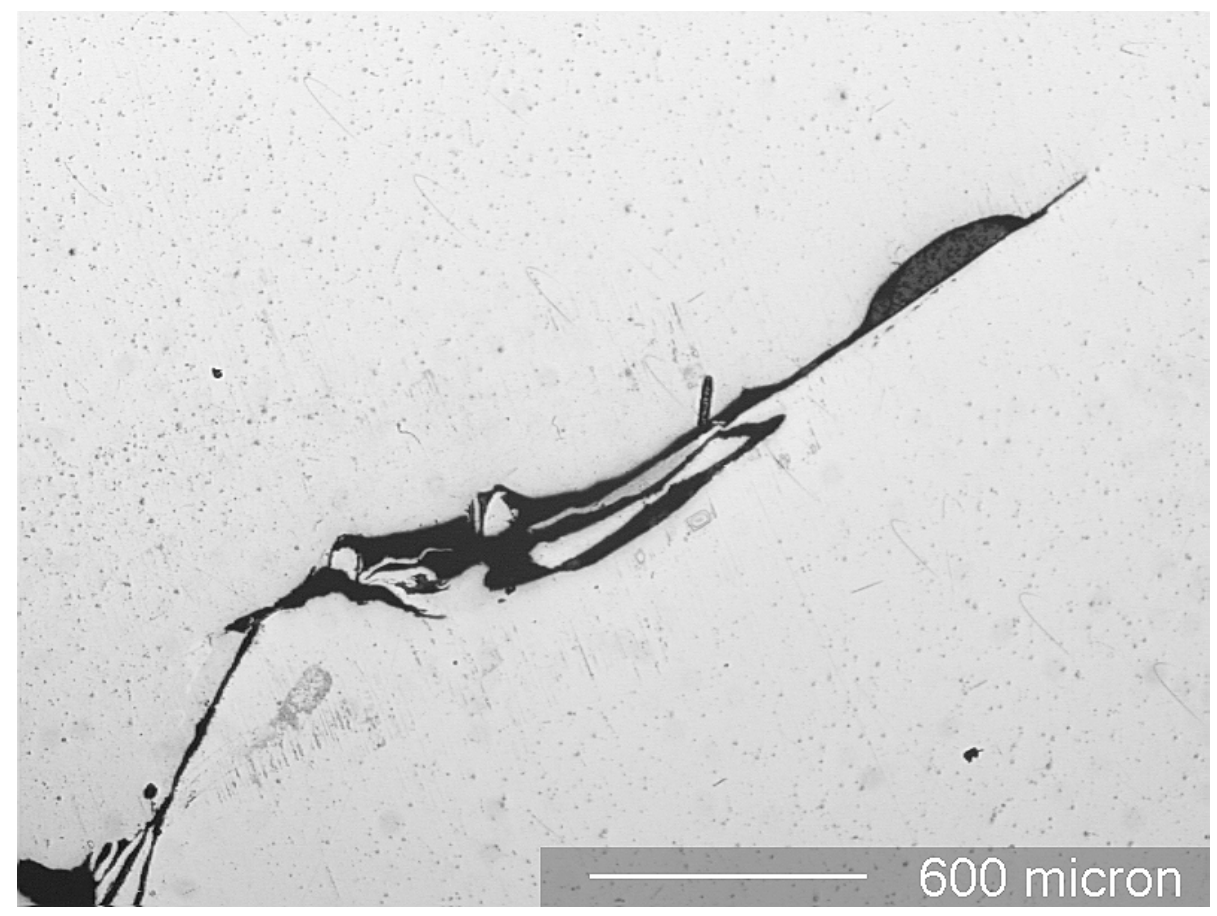

Figure A.6 Flaw C2CC on the End of Seam Repair C, as Machined

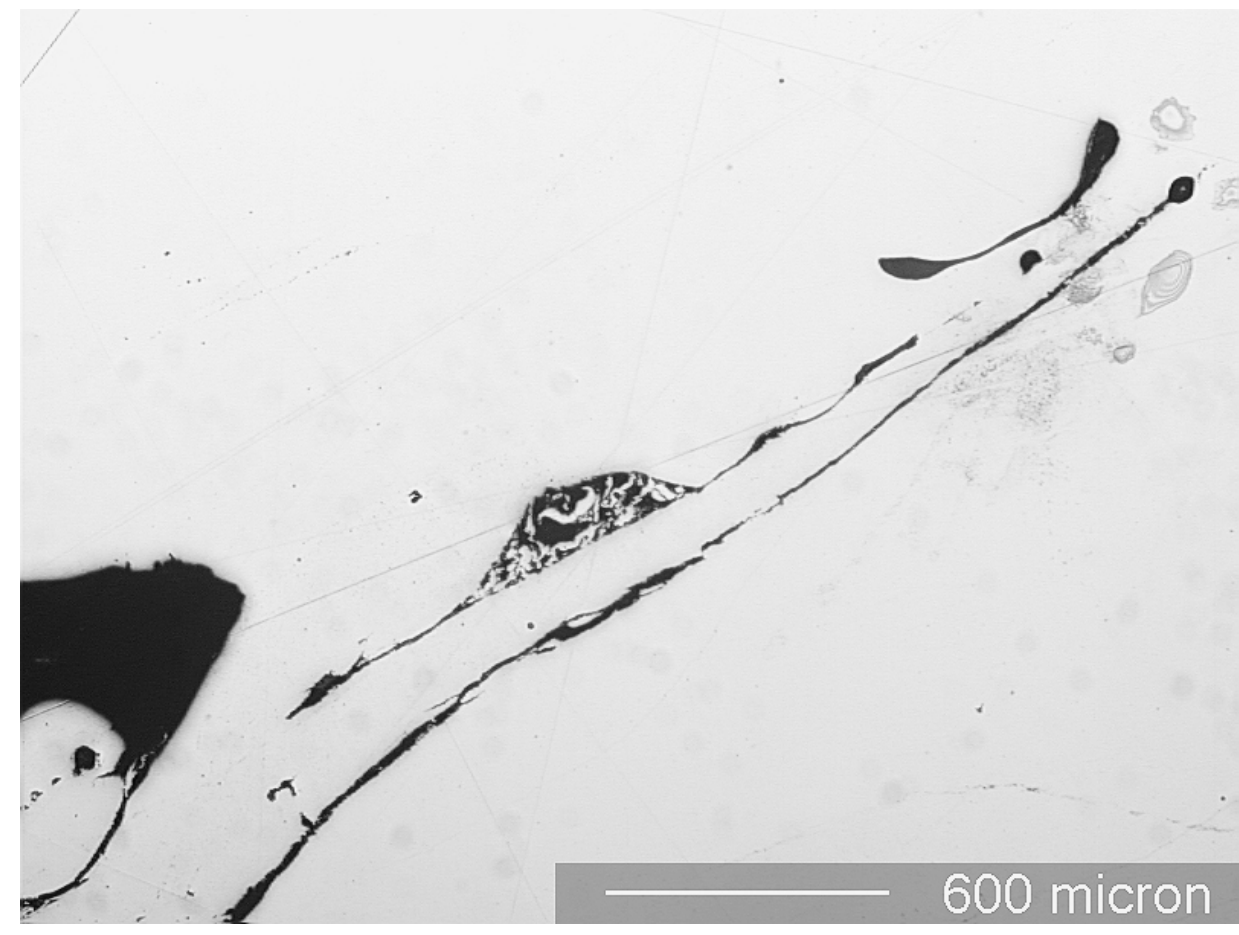

Figure A.7 Flaw C2CC on the End of Seam Repair C, as Machined 


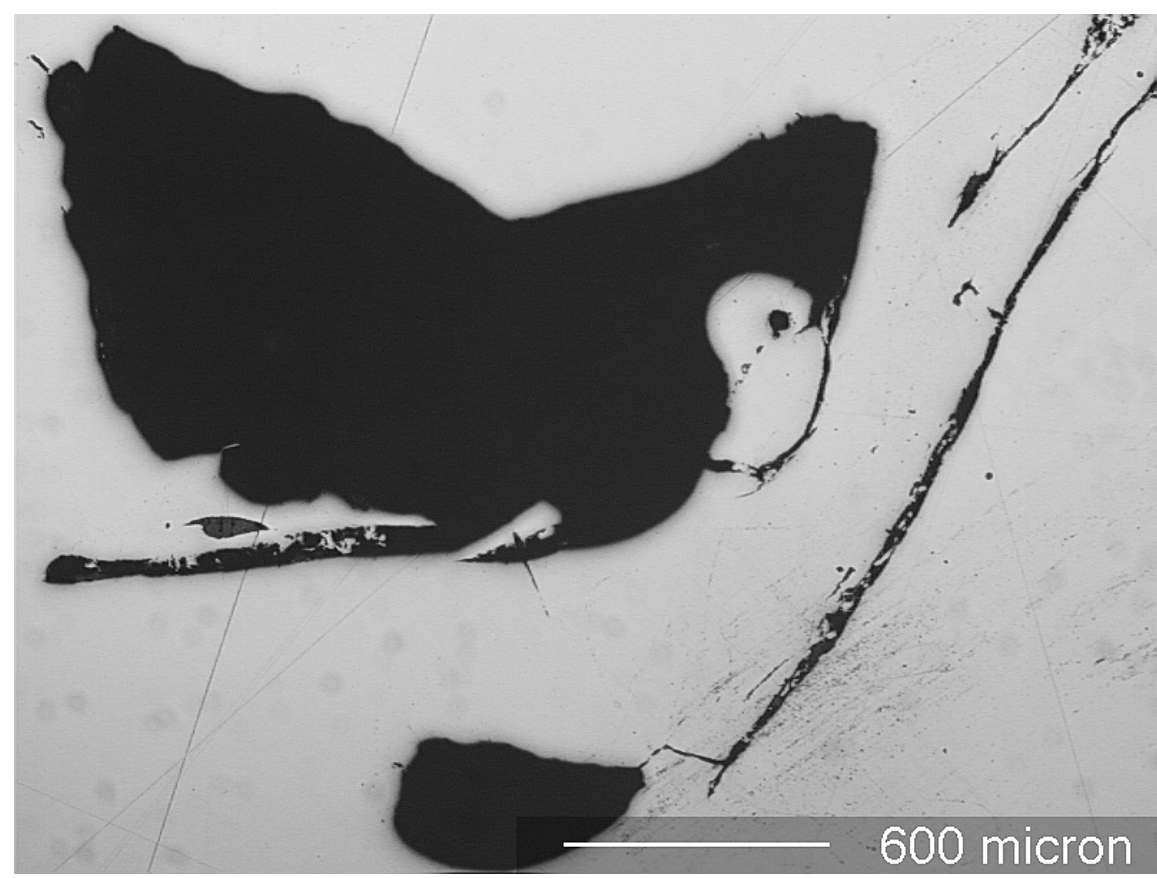

Figure A.8 Flaw C2CC on the End of Seam Repair C, as Machined

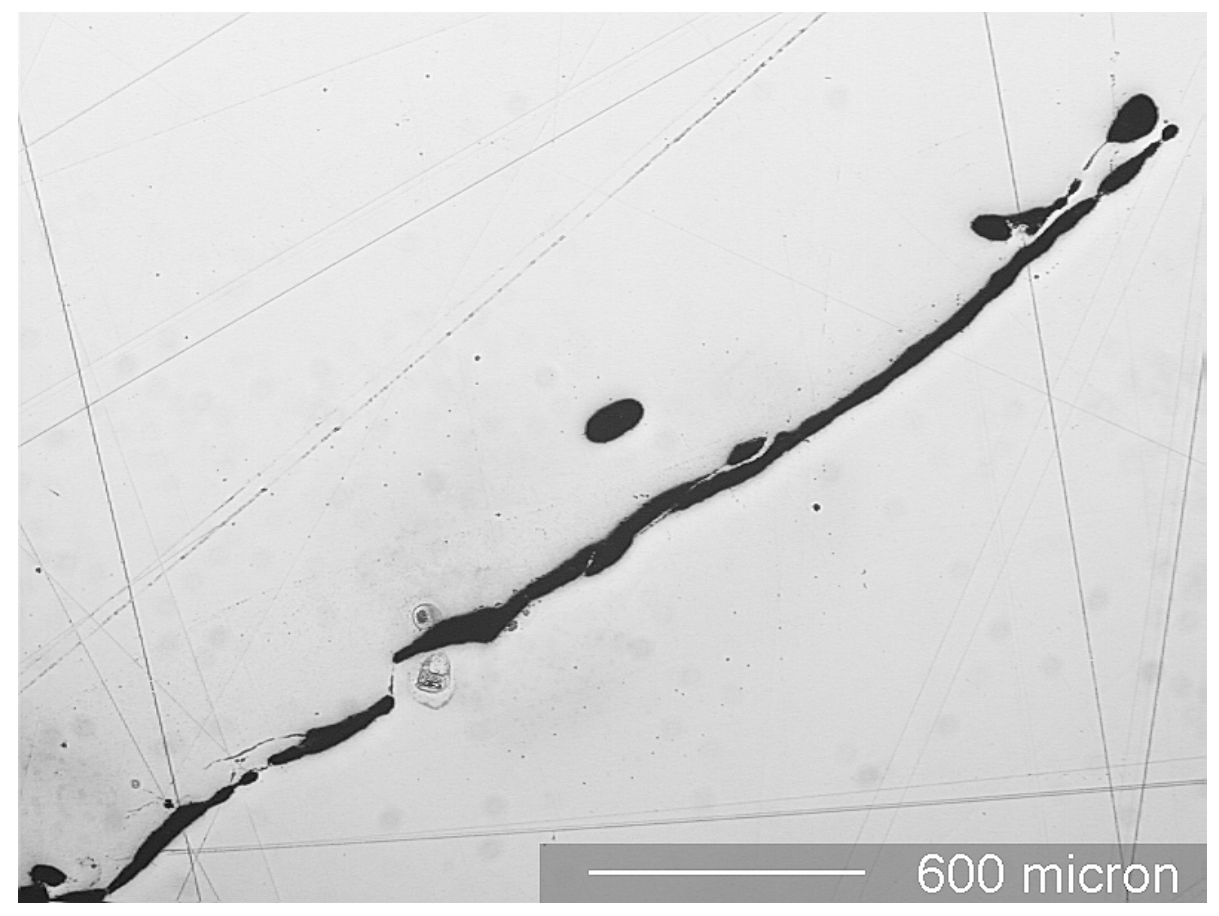

Figure A.9 Flaw C2CC on the End of Seam Repair C, as Machined 


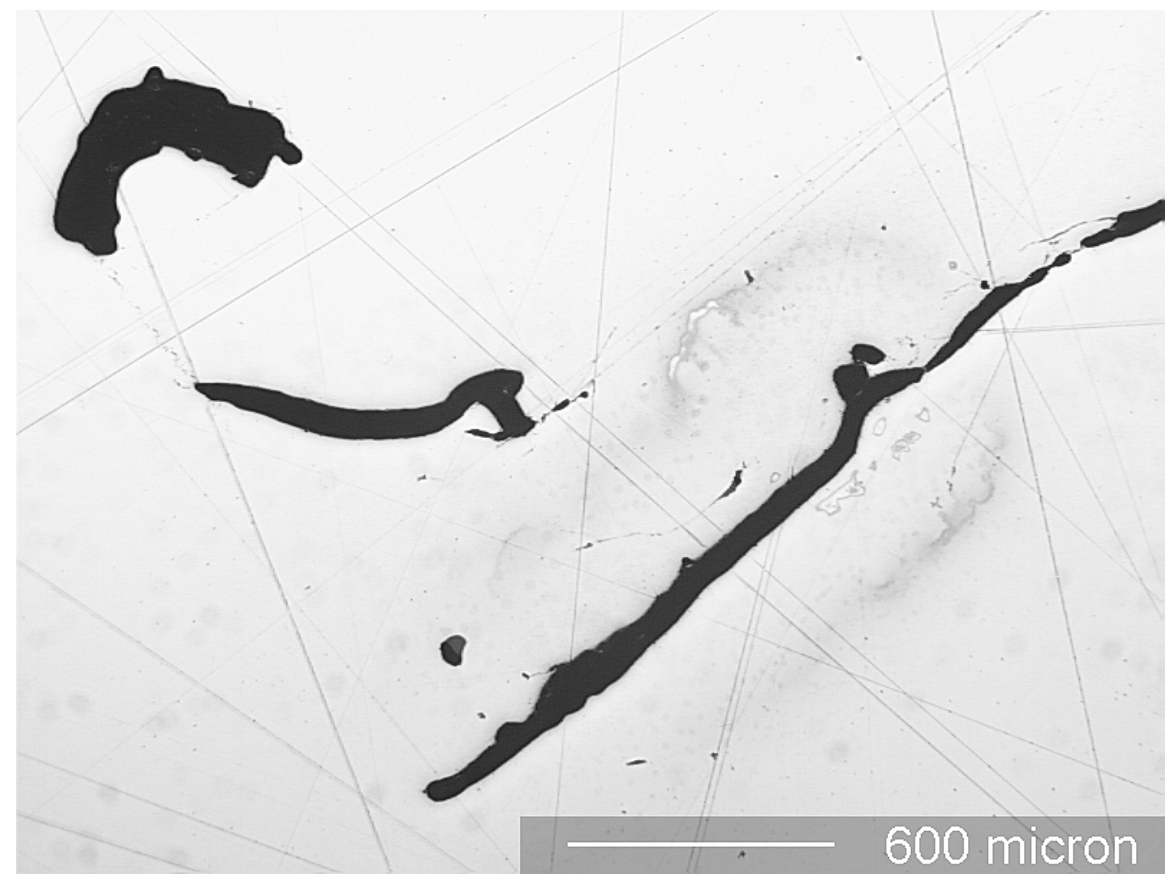

Figure A.10 Flaw C2CC on the End of Seam Repair C, as Machined

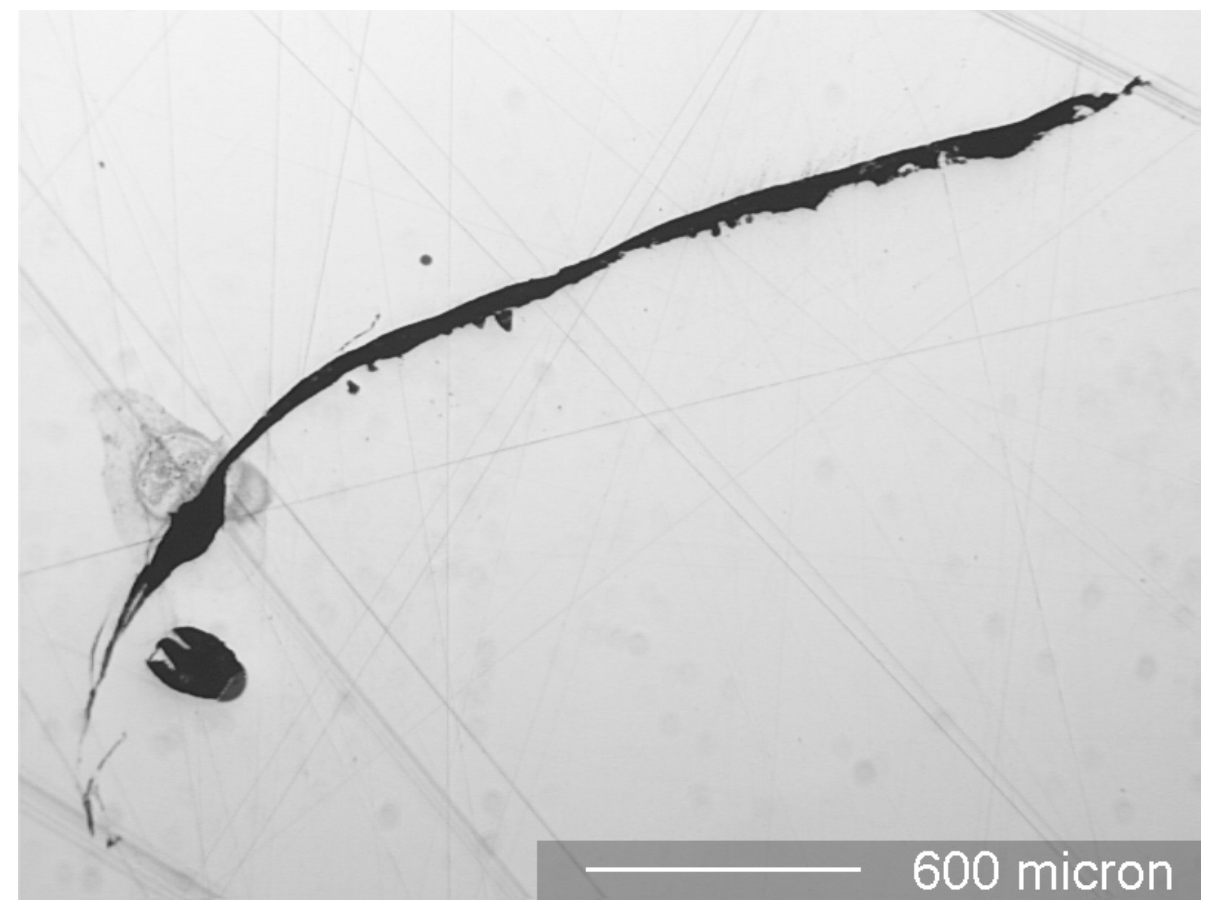

Figure A.11 Flaw C2CC on the End of Seam Repair C, as Machined 


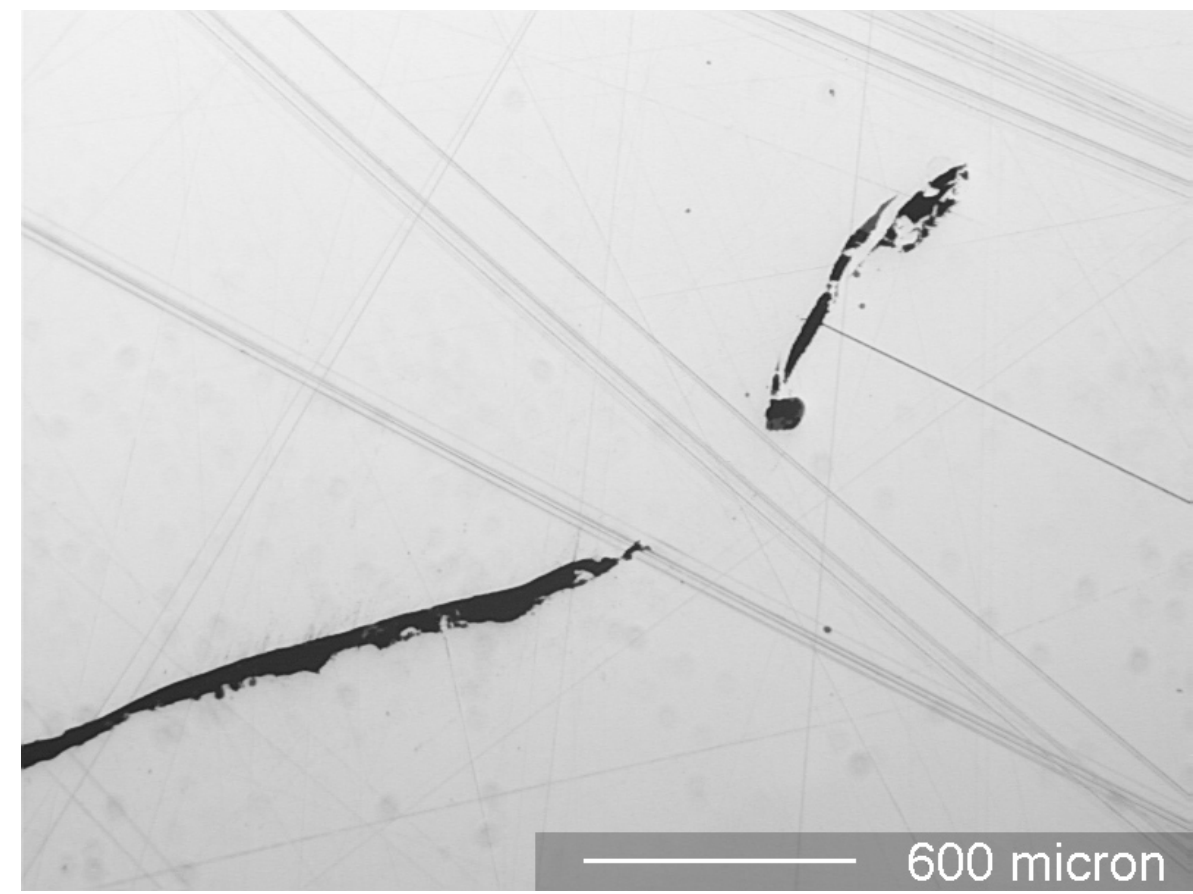

Figure A.12 Flaw C2CC on the End of Seam Repair C, as Machined

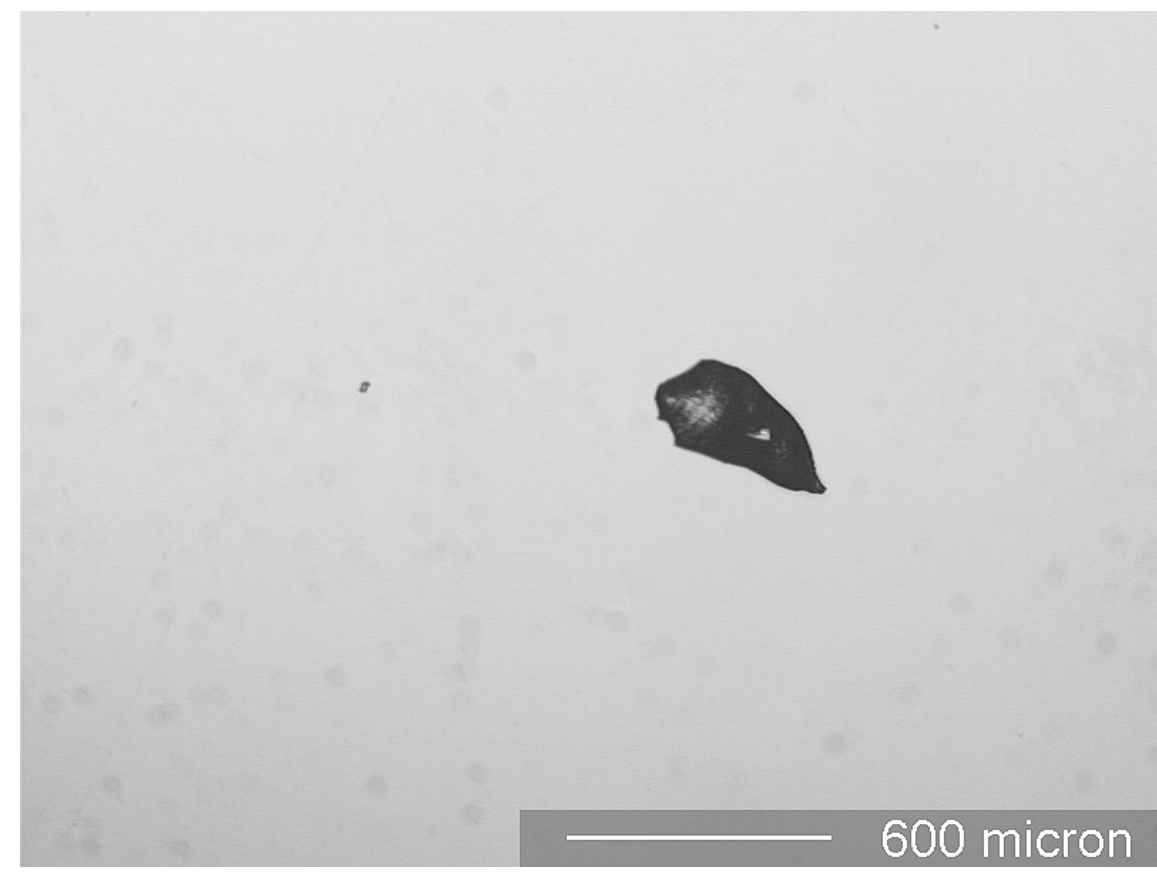

Figure A.13 Flaw C2CC on the End of Seam Repair C, as Machined 


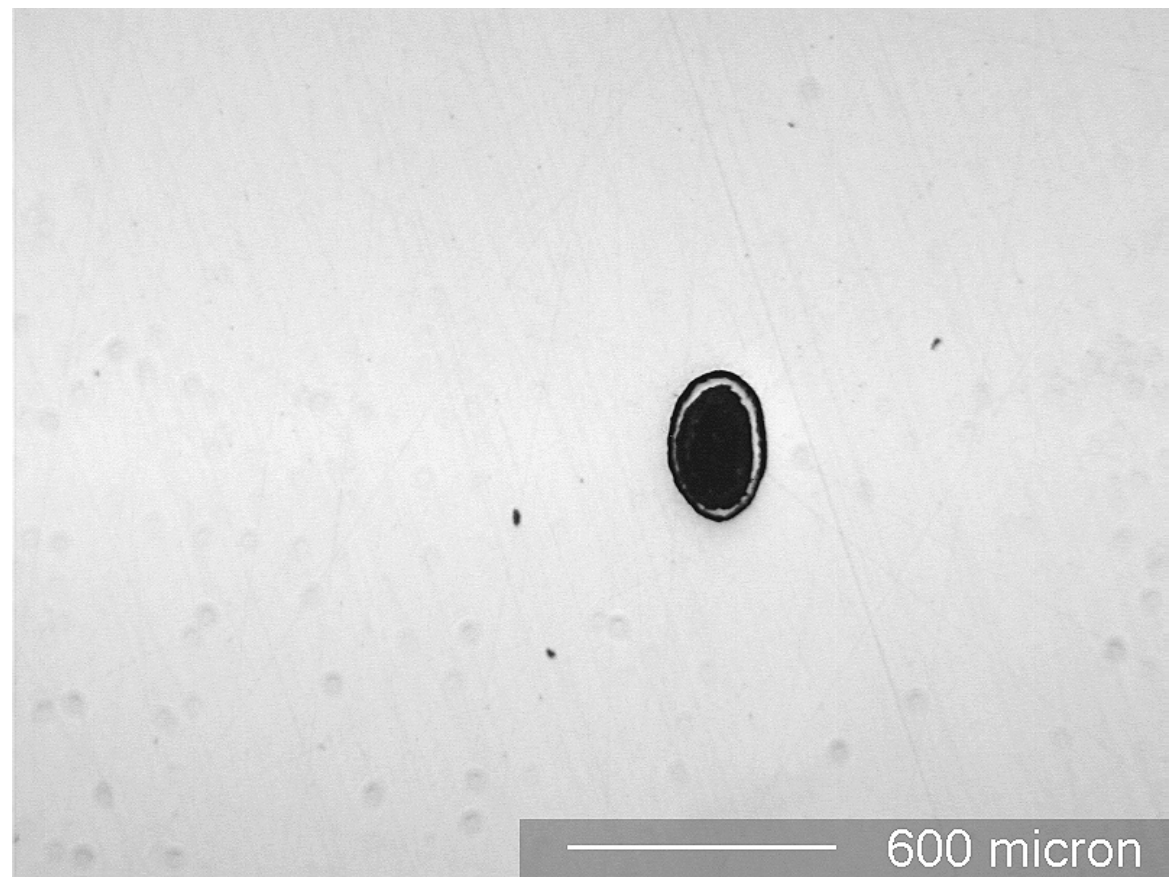

Figure A.14 Flaw C2CC on the End of Seam Repair C, as Machined

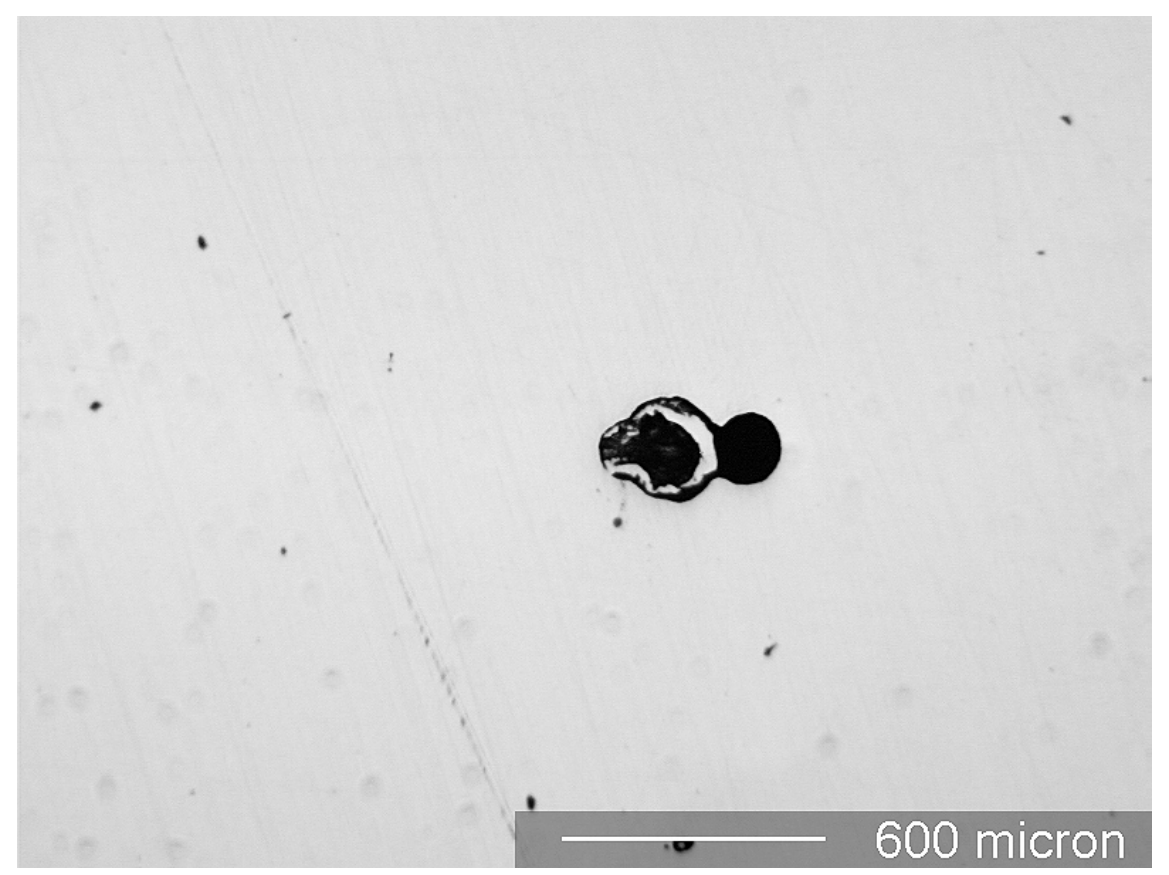

Figure A.15 Flaw C2CC on the End of Seam Repair C, as Machined 


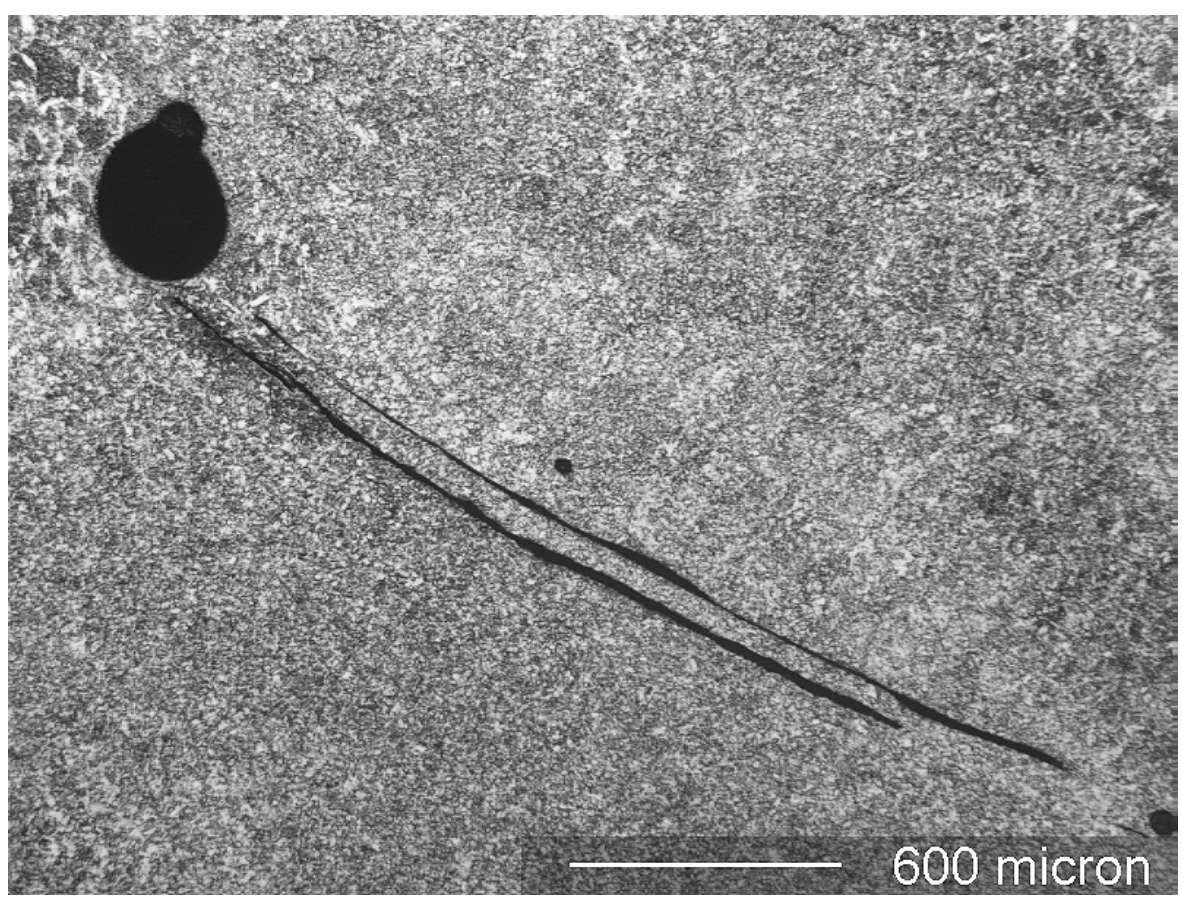

Figure A.16 Flaw C2CC on the End of Seam Repair C, as Polished and Etched

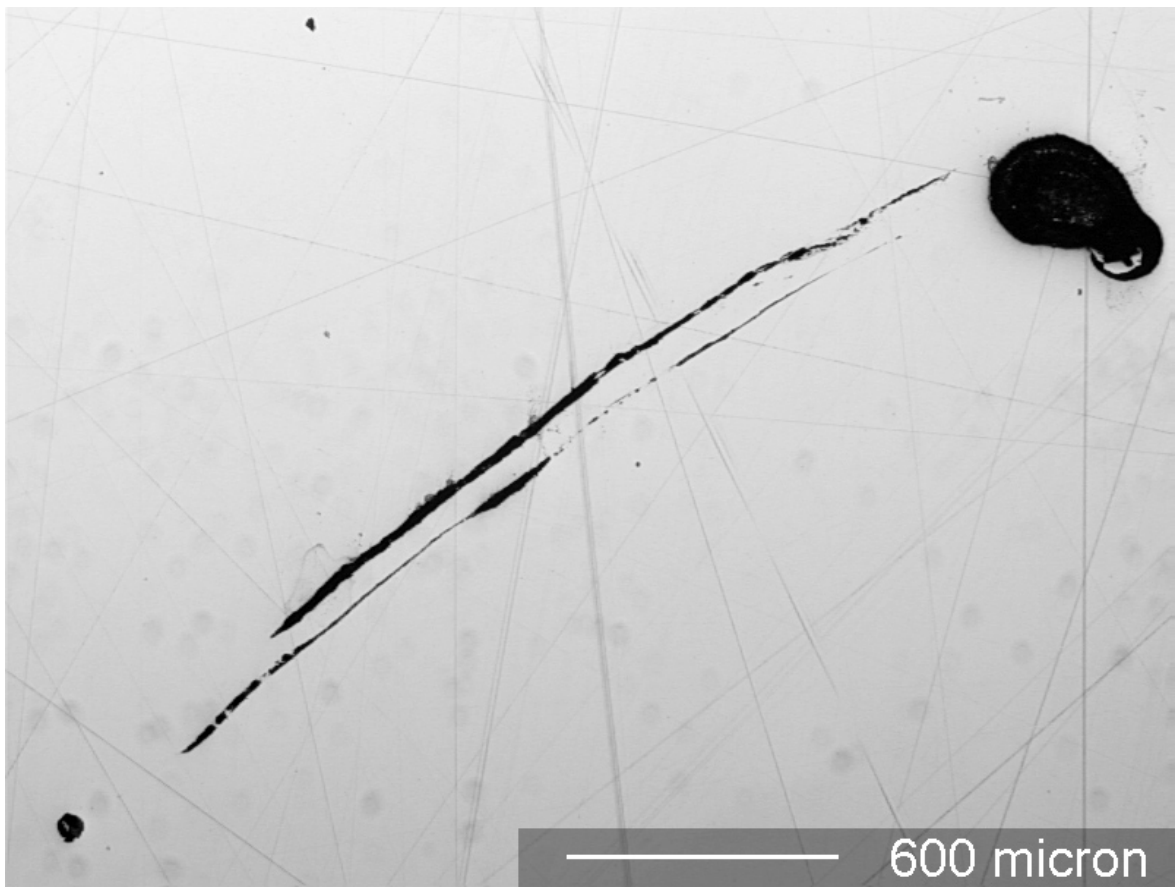

Figure A.17 Flaw C2CC on the End of Seam Repair C, as Machined 


$$
\text { A. } 10
$$


Appendix B

Scanned Electron Microscopy 


\section{Appendix B}

\section{Scanned Electron Microscopy}

This appendix provides the electron micrograph and elemental composition data from the analysis of Specimen C2CC, Hope Creek Unit 2 RPV. This specimen contained a flaw from the end of a repair to a seam weld in the vessel. All of the images acquired in the scanned electron microscopic analysis of this flaw are included in this appendix except for those already documented in Section 4. Also included here are all of the x-ray spectroscopic data sheets from the testing of the flaw.

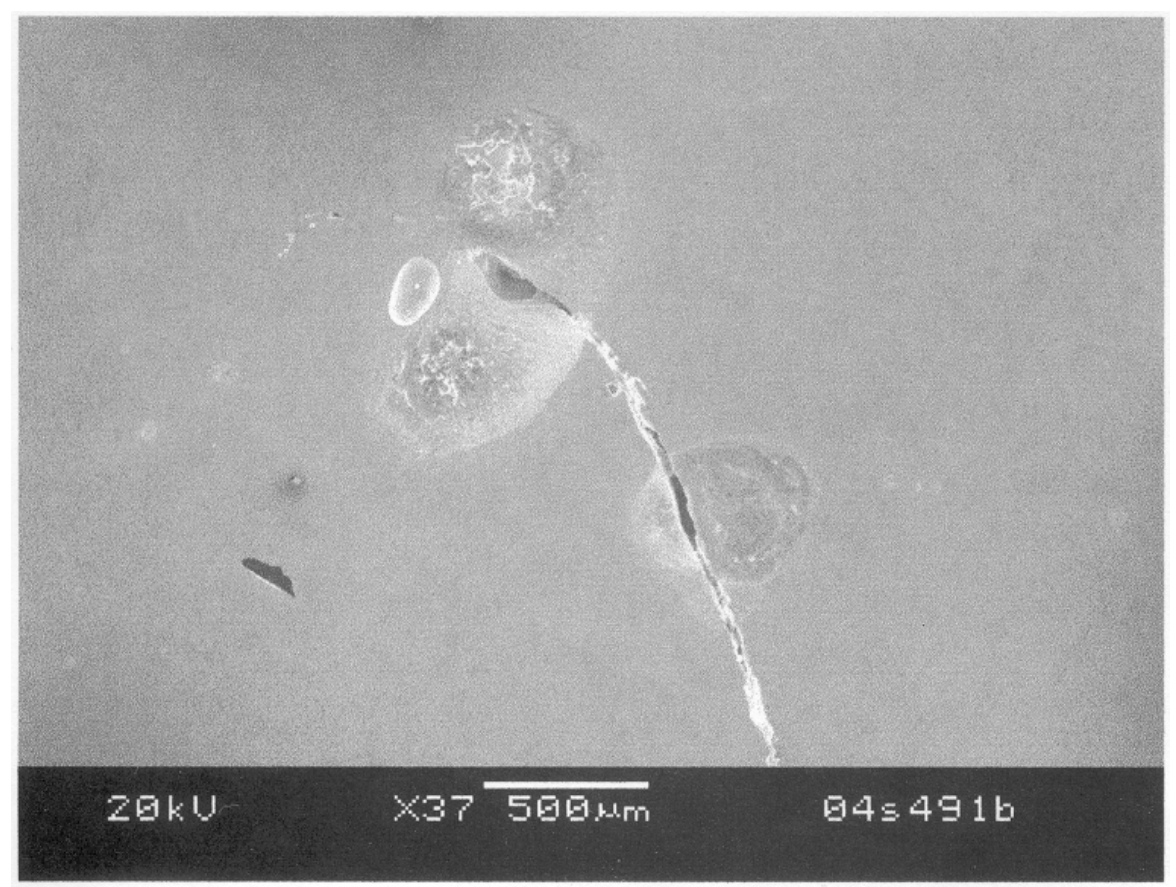

Figure B.1 Flaw C2CC on the End of Seam Repair C 


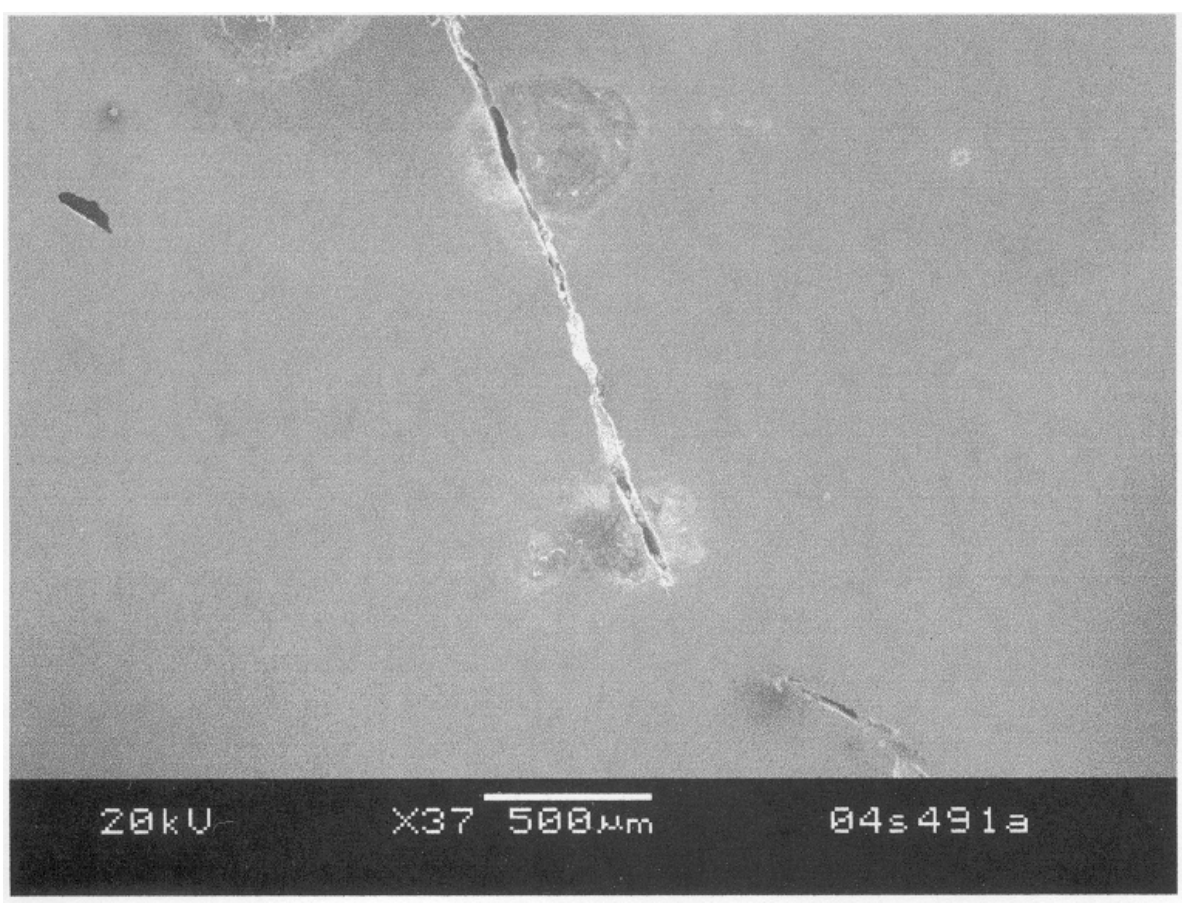

Figure B.2 Flaw C2CC on the End of Seam Repair C

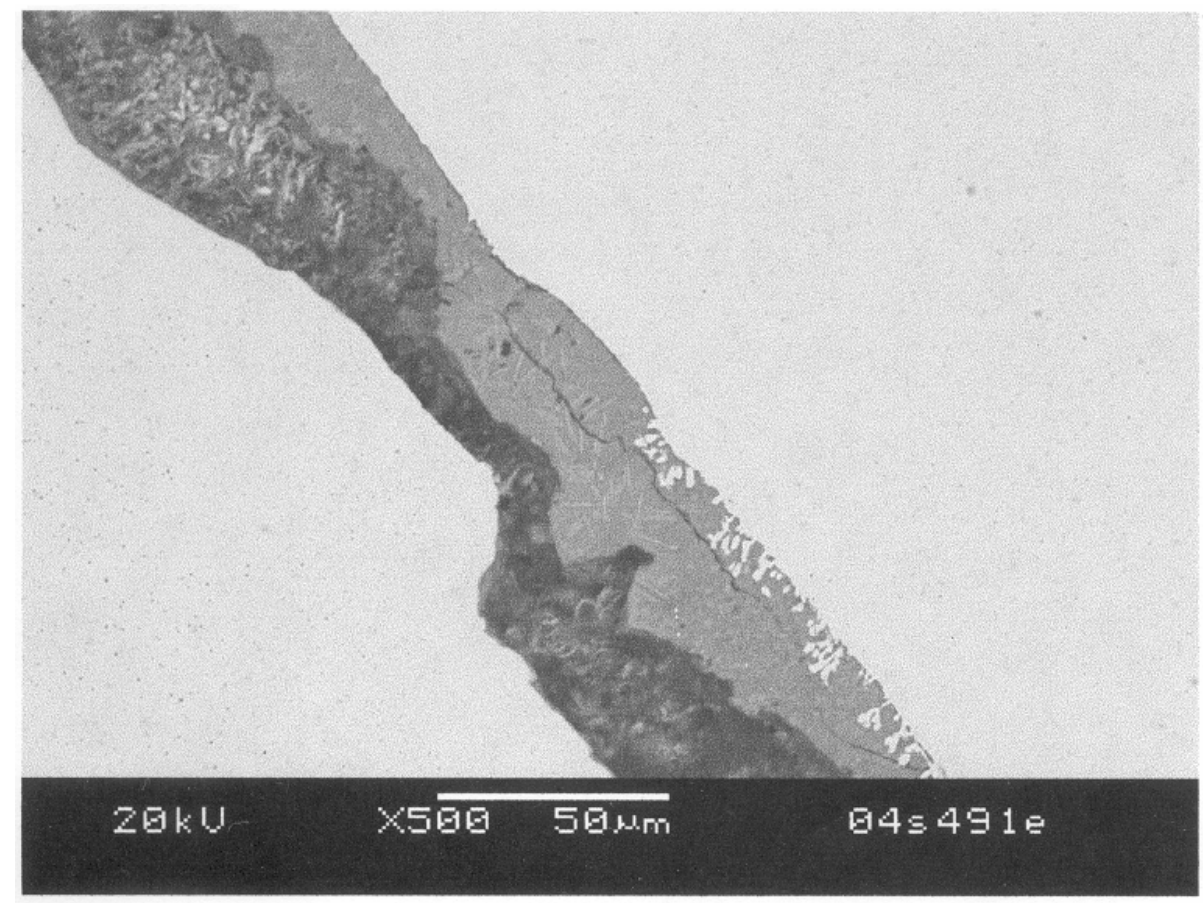

Figure B.3 Flaw C2CC on the End of Seam Repair C 


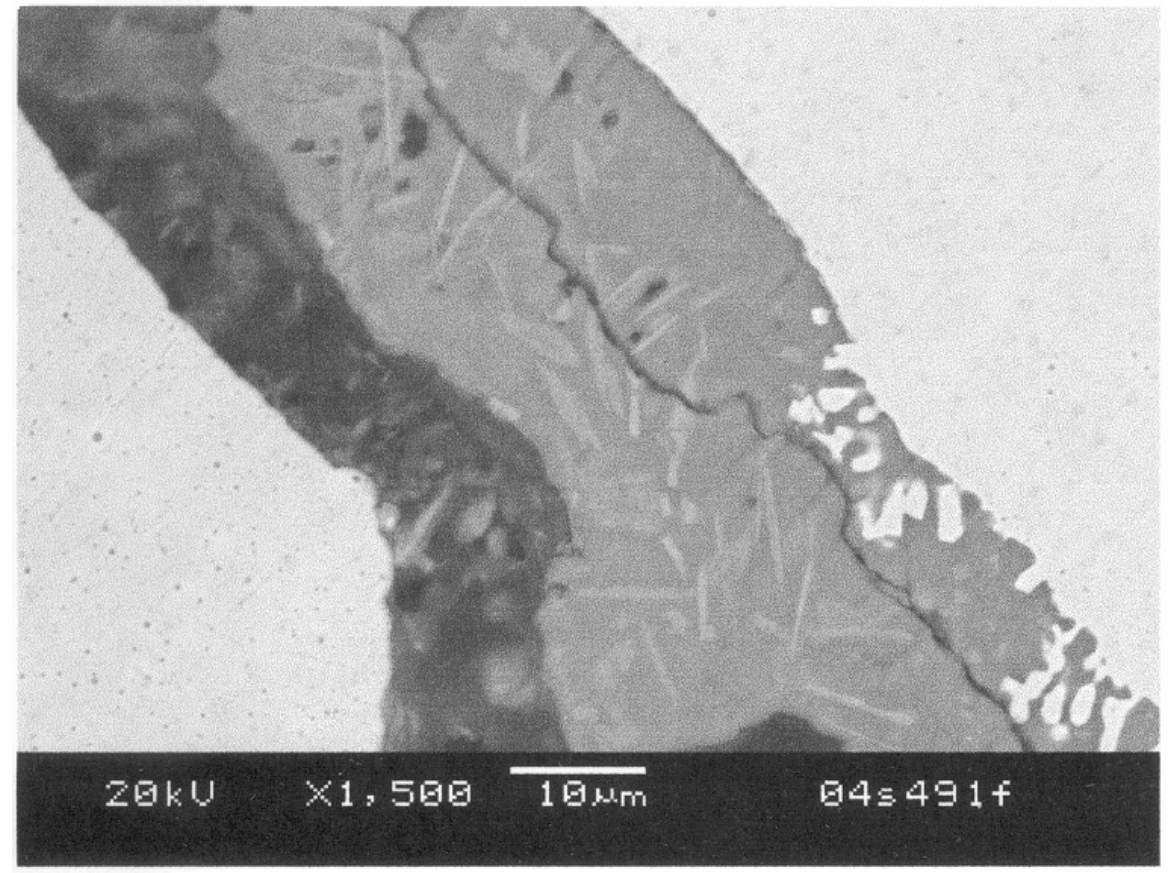

Figure B.4 Flaw C2CC on the End of Seam Repair C

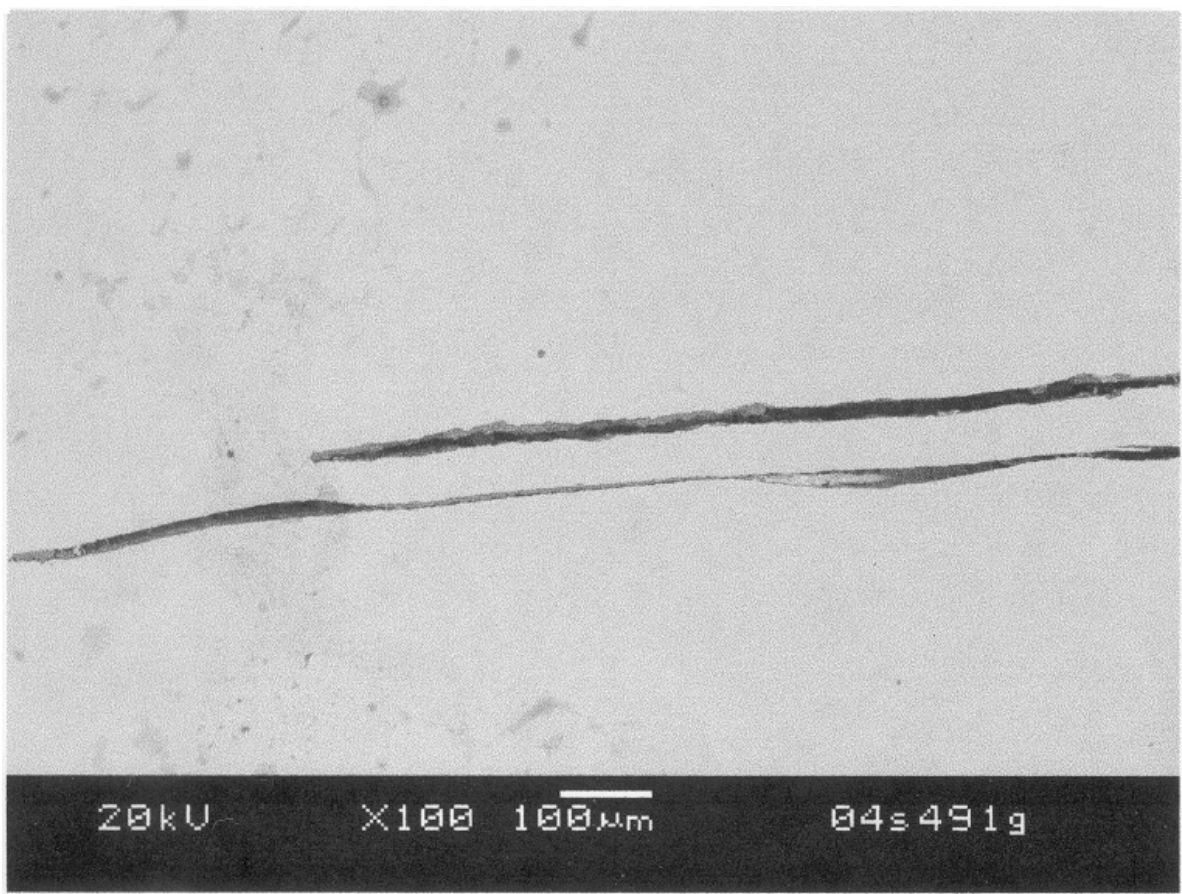

Figure B.5 Flaw C2CC on the End of Seam Repair C 


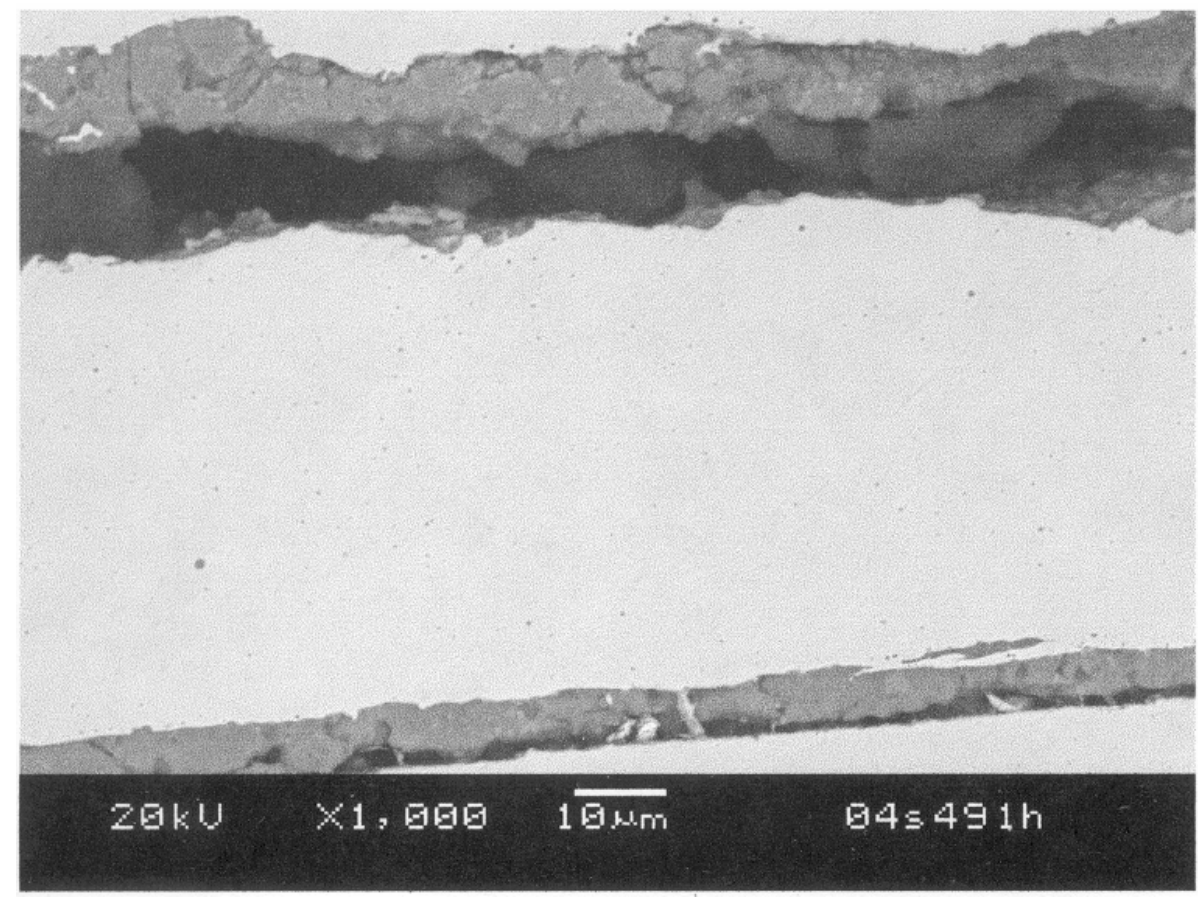

Figure B.6 Flaw C2CC on the End of Seam Repair C

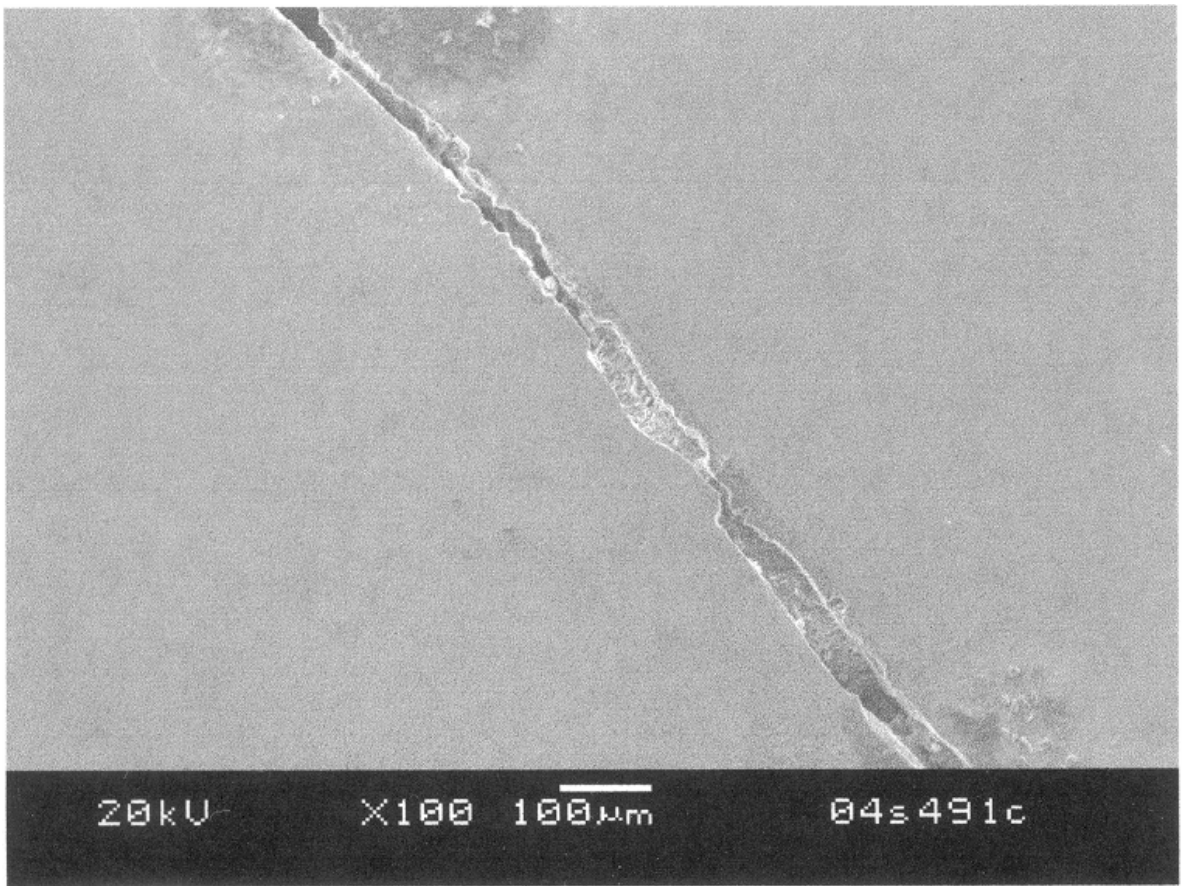

Figure B.7 Flaw C2CC on the End of Seam Repair C 


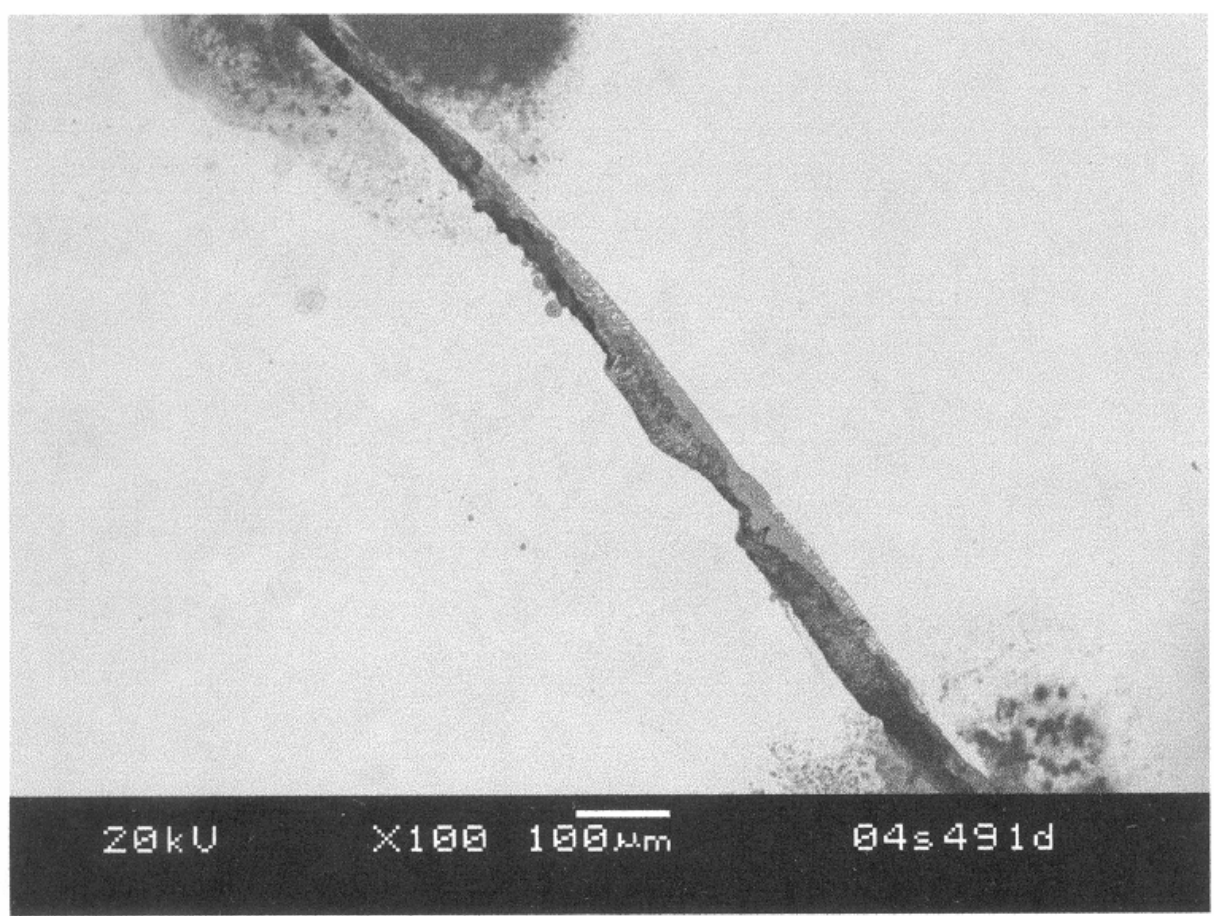

Figure B.8 Flaw C2CC on the End of Seam Repair C 


\section{S491(CRACKS IN METAL)}

Spectrum processing :

Processing option : All elements analyzed (Normalised) Number of iterations $=4$

Standard :

SiO2 28-Jan-2004 05:14 PM

$\mathrm{Na}$ Albite 1-Jun-1999 12:00 AM

$\mathrm{Mg} \mathrm{MgO}$ 1-Jun-1999 12:00 AM

Al Al203 1-Jun-1999 12:00 AM

Si SiO2 28-Jan-2004 05:15 PM

K MAD-10 Feldspar 1-Jun-1999 12:00 AM

Ca Wollastonite 1-Jun-1999 12:00 AM

Ii Ti 1-Jun-1999 12:00 AM

Mn Mn 1-Jun-1999 12:00 AM

Fe Fe 1-Jun-1999 12:00 AM

Comment:

Weight Weight Atomic

\begin{tabular}{|c|c|c|c|c|c|}
\hline 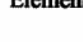 & & y & $\begin{array}{l}\text { Weignt } \\
\%\end{array}$ & $\begin{array}{l}\text { Weight } \\
\%\end{array}$ & $\begin{array}{l}\text { Atomic } \\
\%\end{array}$ \\
\hline & Conc. & Corrn. & & Sigma & \\
\hline $\mathrm{Na} \mathrm{K}$ & $\begin{array}{l}30.98 \\
0.40\end{array}$ & $\begin{array}{l}0.7698 \\
0.5613\end{array}$ & $\begin{array}{l}37.27 \\
0.65\end{array}$ & $\begin{array}{r}0.97 \\
0.14\end{array}$ & $\begin{array}{l}60.53 \\
0.74\end{array}$ \\
\hline $\mathrm{Mg} \mathrm{K}$ & 0.44 & 0.5620 & $\begin{array}{l}0.05 \\
0.73\end{array}$ & $\begin{array}{l}0.14 \\
0.11\end{array}$ & $\begin{array}{l}0.74 \\
0.78\end{array}$ \\
\hline $\mathrm{AlK}$ & 0.57 & 0.6873 & 0.77 & 0.10 & 0.75 \\
\hline Si K & 11.71 & 0.8136 & 13.33 & 0.29 & 12.33 \\
\hline K K & 9.72 & 1.0960 & 8.22 & 0.21 & 5.46 \\
\hline $\mathrm{Ca} \mathrm{K}$ & 4.97 & 1.0123 & 4.55 & 0.16 & 2.95 \\
\hline $\mathrm{Ti} \mathrm{K}$ & 3.03 & 0.8737 & 3.21 & 0.15 & 1.74 \\
\hline $\mathrm{Mn} \mathrm{K}$ & 20.68 & 0.8507 & 22.52 & 0.46 & 10.65 \\
\hline $\mathrm{Fe} \mathrm{K}$ & 8.24 & 0.8718 & 8.75 & 0.31 & 4.07 \\
\hline Totals & & & 100.00 & & \\
\hline
\end{tabular}

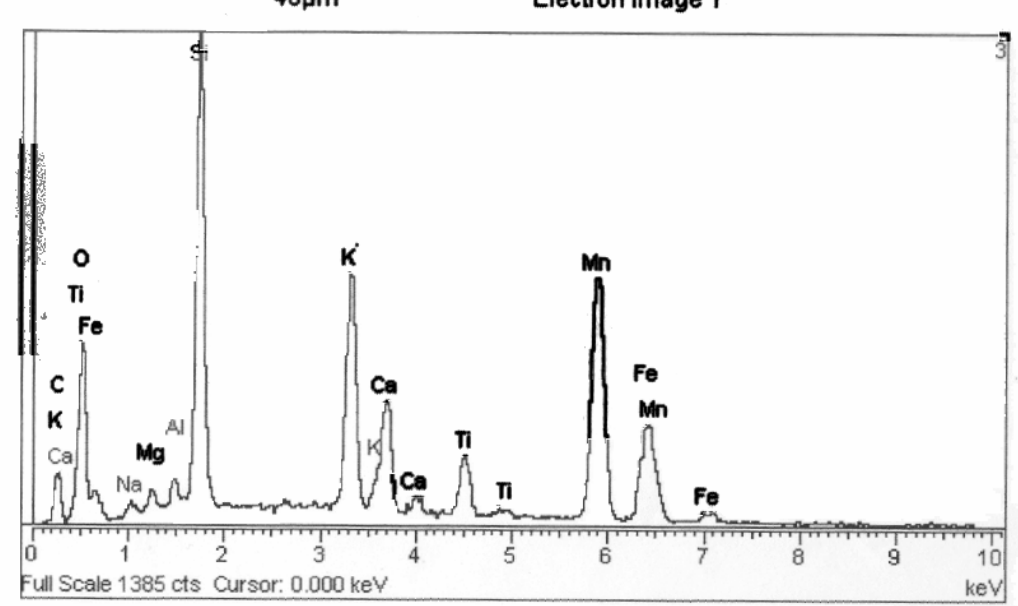

Figure B.9 Elemental Analysis of Flaw in C2CC on the End of Seam Repair C 


\section{S491(CRACKS IN METAL)}

\section{Spectrum processing}

No peaks omitted

Processing option : All elements analyzed (Normalised)

Number of iterations $=3$

\section{Standard :}

O SiO2 28-Jan-2004 05:14 PM

$\mathrm{Si} \mathrm{SiO2} 2$ 28-Jan-2004 05:15 PM

K MAD-10 Feldspar 1-Jun-1999 12:00 AM

Ca Wollastonite 1-Jun-1999 12:00 AM

Ti Ti 1-Jun-1999 12:00 AM

Mn Mn 1-Jun-1999 12:00 AM

$\mathrm{Fe} \mathrm{Fe}$ 1-Jun-1999 12:00 AM

\begin{tabular}{|c|c|c|c|c|c|}
\hline Element & & $\begin{array}{l}\text { Intensit } \\
\mathbf{y}\end{array}$ & $\begin{array}{l}\text { Weight } \\
\%\end{array}$ & $\begin{array}{l}\text { Weight } \\
\%\end{array}$ & $\begin{array}{l}\text { Atomic } \\
\%\end{array}$ \\
\hline & Conc. & Corm. & & Sigma & \\
\hline OK & 12.08 & 0.3618 & 40.70 & 1.40 & 61.89 \\
\hline Si K & 8.46 & 0.8965 & 11.51 & 0.33 & 9.97 \\
\hline K K & 0.77 & 1.1652 & 0.80 & 0.10 & 0.50 \\
\hline $\mathrm{CaK}$ & 35.00 & 1.0294 & 41.47 & 1.00 & 25.17 \\
\hline Ti K & 0.43 & 0.7498 & 0.71 & 0.11 & 0.36 \\
\hline Mn K & 1.97 & 0.7904 & 3.05 & 0.20 & 1.35 \\
\hline $\mathrm{Fe} \mathrm{K}$ & 1.18 & 0.8163 & 1.77 & 0.18 & 0.77 \\
\hline Totals & & & 100.00 & & \\
\hline
\end{tabular}

Comment:
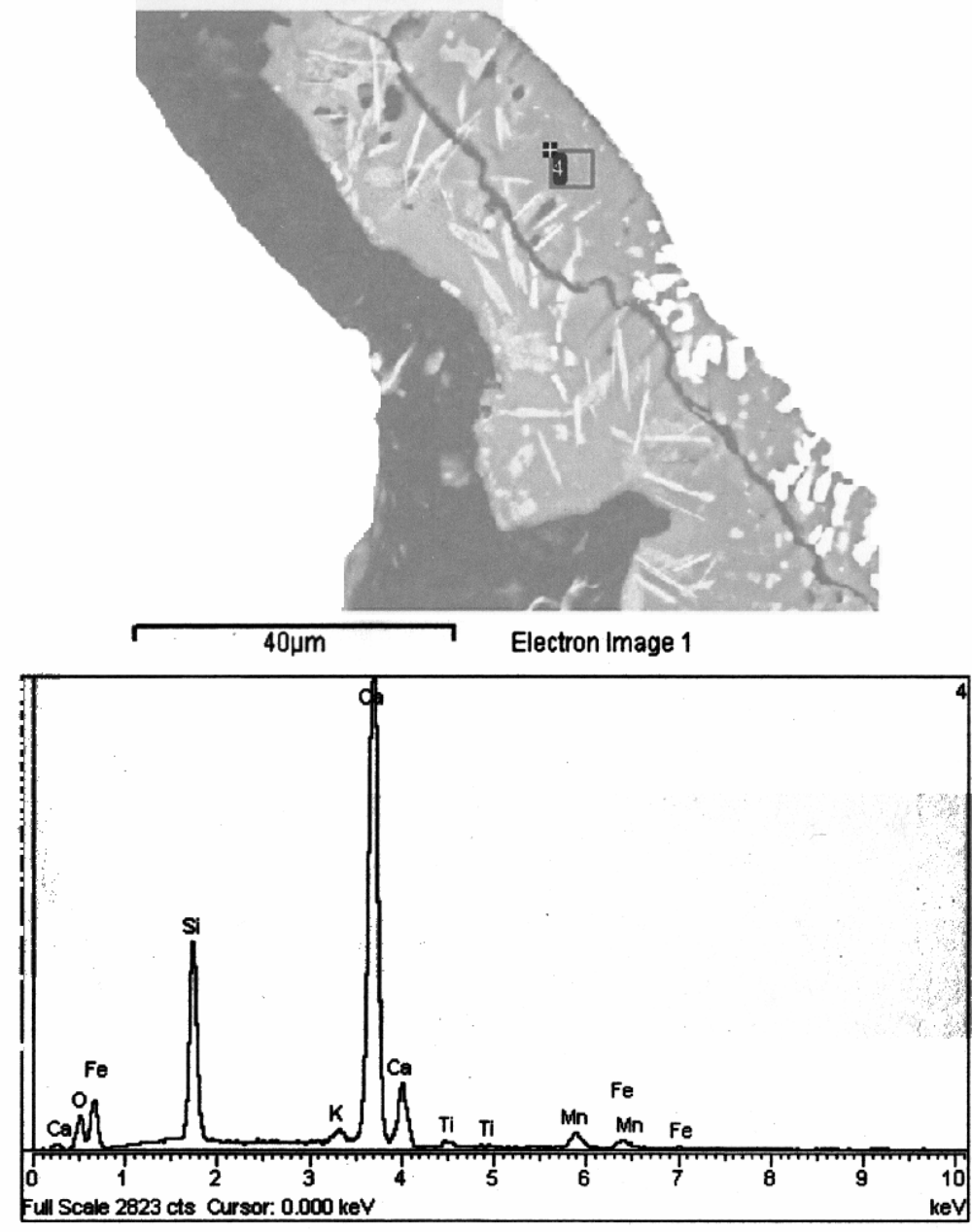

Figure B.10 Elemental Analysis of Flaw in C2CC on the End of Seam Repair C 


\section{S491(CRACKS IN METAL)}

Spectrum processing

No peaks omitted

Processing option : All elements analyzed (Normalised) Number of iterations $=4$

Standard

O SiO2 28-Jan-2004 05:14 PM

$\mathrm{Na}$ Albite 1-Jun-1999 12:00 AM

Si SiO2 28-Jan-2004 05:15 PM

K MAD-10 Feldspar 1-Jun-1999 12:00 AM

Ca Wollastonite 1-Jun-1999 12:00 AM

Ti Ti 1-Jun-1999 12:00 AM

Mn Mn

$\mathrm{Fe}$ Fe 1-Jun-1999 12:00 AM

\begin{tabular}{|c|c|c|c|c|c|}
\hline Element & $\begin{array}{l}\text { App } \\
\text { Conc. }\end{array}$ & $\begin{array}{l}\text { Intensit } \\
\text { y } \\
\text { Corm }\end{array}$ & $\begin{array}{l}\text { Weight } \\
\%\end{array}$ & $\begin{array}{l}\text { Weight } \\
\% \\
\text { Sigma }\end{array}$ & $\begin{array}{l}\text { Atomic } \\
\%\end{array}$ \\
\hline OK & 17.44 & 0.3936 & 42.62 & 1.35 & 64.13 \\
\hline $\mathrm{NaK}$ & 0.26 & 0.6354 & 0.40 & 0.12 & 0.42 \\
\hline Si K & 9.56 & 0.8816 & 10.43 & 0.30 & 8.94 \\
\hline $\mathbf{K K}$ & 0.77 & 1.1591 & 0.64 & 0.09 & 0.39 \\
\hline $\mathrm{Ca} \mathrm{K}$ & 38.61 & 1.0358 & 35.85 & 0.87 & 21.53 \\
\hline Ti K & 2.32 & 0.7672 & 2.91 & 0.16 & 1.46 \\
\hline $\operatorname{Mn} \mathrm{K}$ & 4.63 & 0.7961 & 5.59 & 0.25 & 2.45 \\
\hline $\mathrm{Fe} \mathrm{K}$ & 1.33 & 0.8213 & 1.56 & 0.19 & 0.67 \\
\hline Tótals & & & 100.00 & & \\
\hline
\end{tabular}

Comment:

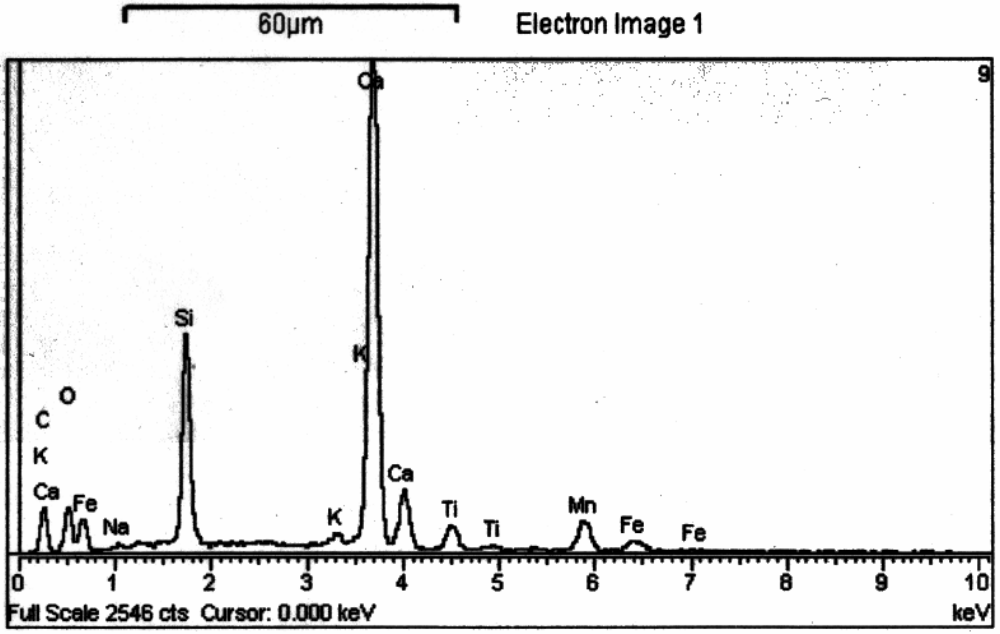

Figure B.11 Elemental Analysis of Flaw in C2CC on the End of Seam Repair C 
Spectrum processing

No peaks omitted

Processing option : All elements analyzed (Normalised)

Number of iterations $=4$

Standard :

O SiO2 28-Jan-2004 05:14 PM

$\mathrm{Si}$ SiO2 28-Jan-2004 05:15 PM

MAD-10 Feldspar 1-Jun-1999 12:00 AM

Ca Wollastonite 1-Jun-1999 12:00 AM

Ti Ti 1-Jun-1999 12:00 AM

Mn Mn 1-Jun-199912.00 AM

\begin{tabular}{l|lllll}
\hline Element & App & $\begin{array}{l}\text { Intensit } \\
\text { W }\end{array}$ & $\begin{array}{l}\text { Weight } \\
\%\end{array}$ & $\begin{array}{l}\text { Weight } \\
\%\end{array}$ & $\begin{array}{l}\text { Atomic } \\
\%\end{array}$ \\
O K & Conc. & Corm. & & Sigma & \\
Si K & 14.08 & 0.3260 & 39.54 & 1.50 & 63.10 \\
K K & 5.05 & 0.8695 & 5.31 & 0.19 & 4.83 \\
Ca K & 33.59 & 1.1980 & 0.45 & 0.08 & 0.29 \\
Ti K & 19.11 & 0.8047 & 28.30 & 0.74 & 18.03 \\
Mn K & 2.32 & 0.7951 & 2.67 & 0.60 & 11.59 \\
Fe K & 1.78 & 0.8238 & 1.98 & 0.18 & 0.94 \\
Totals & & & 100.00 & & \\
\hline
\end{tabular}
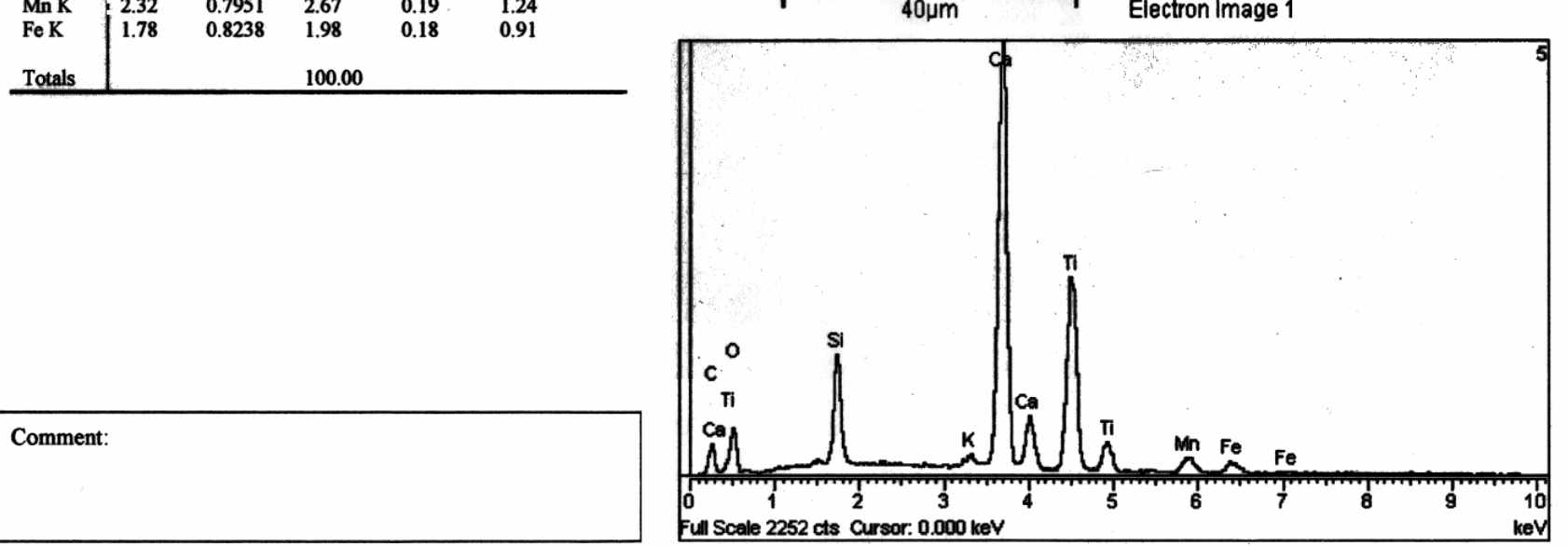

Figure B.12 Elemental Analysis of Flaw in C2CC on the End of Seam Repair C 
Spectrum processing

No peaks omitted

Processing option : All elements analyzed (Normalised) Number of iterations $=2$

Standard :

Standard:
$\mathrm{Si}$ SiO2 28-Jan-2004 05:15 PM

$\begin{array}{lll}\mathrm{Si} & \mathrm{SiO2} 2 \text { 28-Jan-2004 05:15 PM } \\ \mathrm{Ca} & \text { Wollastonite 1-Jun-1999 12:00 AM }\end{array}$

Mn Mn 1-Jun-1999 12:00 AM

Fe $\mathrm{Fe} 1$ - Jun-1999 12:00 AM

\begin{tabular}{l|lllll}
\hline Element & App & $\begin{array}{l}\text { Intensit } \\
\text { y }\end{array}$ & $\begin{array}{l}\text { Weight } \\
\%\end{array}$ & $\begin{array}{l}\text { Weight } \\
\%\end{array}$ & $\begin{array}{l}\text { Atomic } \\
\%\end{array}$ \\
Si K & Conc. & Corm. & & Sigma & \\
Ca K & 5.84 & 0.6450 & 1.30 & 0.13 & 2.51 \\
Ti K & 1.69 & 1.1592 & 4.64 & 0.14 & 6.25 \\
Mn K & 0.61 & 0.9600 & 0.64 & 0.13 & 1.86 \\
Fe K & 89.76 & 0.9846 & 91.77 & 0.27 & $\mathbf{8 8 . 7 6}$ \\
Totals & & & 100.00 & & \\
\hline
\end{tabular}

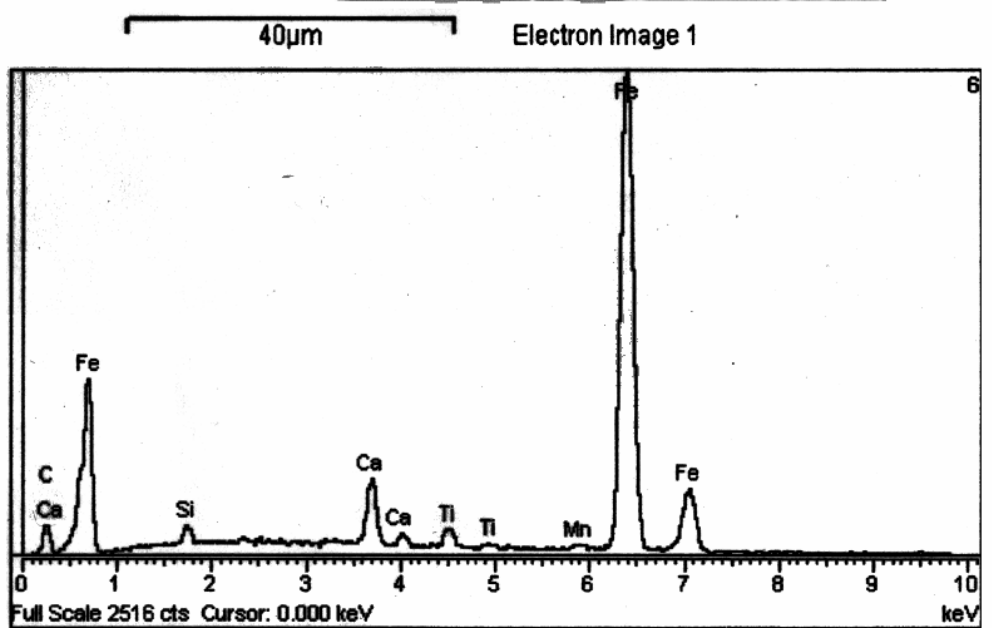

Figure B.13 Elemental Analysis of Flaw in C2CC on the End of Seam Repair C 


\section{S491(CRACKS IN METAL)}

Spectrum processing

No peaks omitted

Processing option : All elements analyzed (Normalised)

Number of iterations $=4$

\section{Standard}

O SiO2 28-Jan-2004 05:14 PM

Na Albite 1-Jun-1999 12:00 AM

Si SiO2 28-Jan-2004 05:15 PM

K MAD-10 Feldspar 1-Jun-1999 12:00 AM

Ca Wollastonite 1-Jun-1999 12:00 AM

Ti Ti 1-Jun-1999 12:00 AM

Mn Mn 1-Jun-1999 12:00 AM

Fe $\mathrm{Fe}$ 1-Jun-1999 12:00 AM

\begin{tabular}{l|lllll}
\hline Element & App & $\begin{array}{l}\text { Intensit } \\
\text { y }\end{array}$ & $\begin{array}{l}\text { Weight } \\
\%\end{array}$ & $\begin{array}{l}\text { Weight } \\
\%\end{array}$ & $\begin{array}{l}\text { Atomic } \\
\%\end{array}$ \\
& Conc. & Corm. & & Sigma & \\
$\mathrm{OK}$ & 19.85 & 0.4149 & 43.51 & 1.21 & 64.64 \\
$\mathrm{Na} \mathrm{K}$ & 0.30 & 0.6421 & 0.42 & 0.12 & 0.43 \\
$\mathrm{Si} \mathrm{K}$ & 12.00 & 0.8849 & 12.33 & 0.32 & 10.44 \\
$\mathrm{~K} \mathrm{~K}$ & 0.73 & 1.1426 & 0.58 & 0.09 & 0.35 \\
$\mathrm{Ca} \mathrm{K}$ & 37.26 & 1.0301 & 32.90 & 0.74 & 19.51 \\
$\mathrm{Ti} \mathrm{K}$ & 2.52 & 0.7720 & 2.96 & 0.16 & 1.47 \\
$\mathrm{Mn} \mathrm{K}$ & $\mathbf{5 . 2 7}$ & 0.7976 & 6.00 & 0.25 & 2.60 \\
$\mathrm{Fe} \mathrm{K}$ & 1.17 & 0.8222 & 1.30 & 0.17 & 0.55 \\
& & & 100.00 & & \\
Totals & & & & \\
\hline
\end{tabular}

Comment:

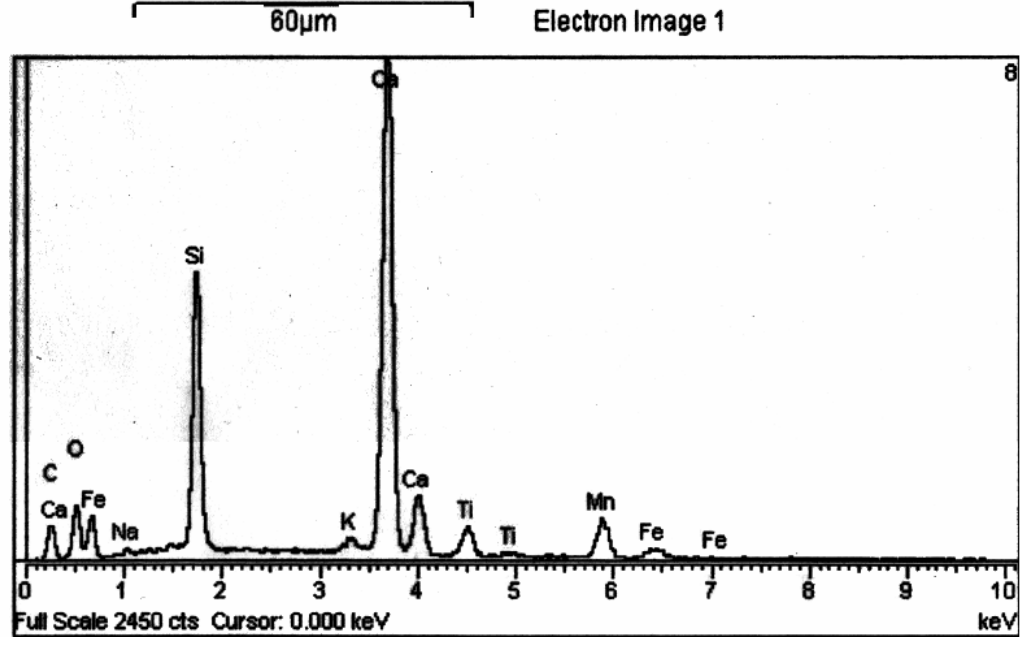

Figure B.14 Elemental Analysis of Flaw in C2CC on the End of Seam Repair C 


\section{S491(CRACKS IN METAL)}

Spectrum processing :

Peaks possibly omitted : $2620,3.695 \mathrm{keV}$

Processing option : All elements analyzed (Normalised) Number of iterations $=2$

Standard :

Mn Mn 1-Jun-1999 12:00 AM

$\mathrm{Fe} \quad \mathrm{Fe}$ 1-Jun-1999 12:00 AM

\begin{tabular}{l|lllll}
\hline Element & App & $\begin{array}{l}\text { Intensit } \\
\text { y }\end{array}$ & $\begin{array}{l}\text { Weight } \\
\%\end{array}$ & $\begin{array}{l}\text { Weight } \\
\%\end{array}$ & $\begin{array}{l}\text { Atomic } \\
\%\end{array}$ \\
Mn K & Conc. & $\begin{array}{l}\text { Corrn. } \\
\text { Sigma }\end{array}$ & \\
Fe K & 102.83 & 0.9778 & 0.96 & 0.16 & 0.97 \\
Ni K & 1.00 & 0.8800 & 97.96 & 0.27 & 98.00 \\
Totals & & & 0.22 & 1.03 \\
\hline
\end{tabular}
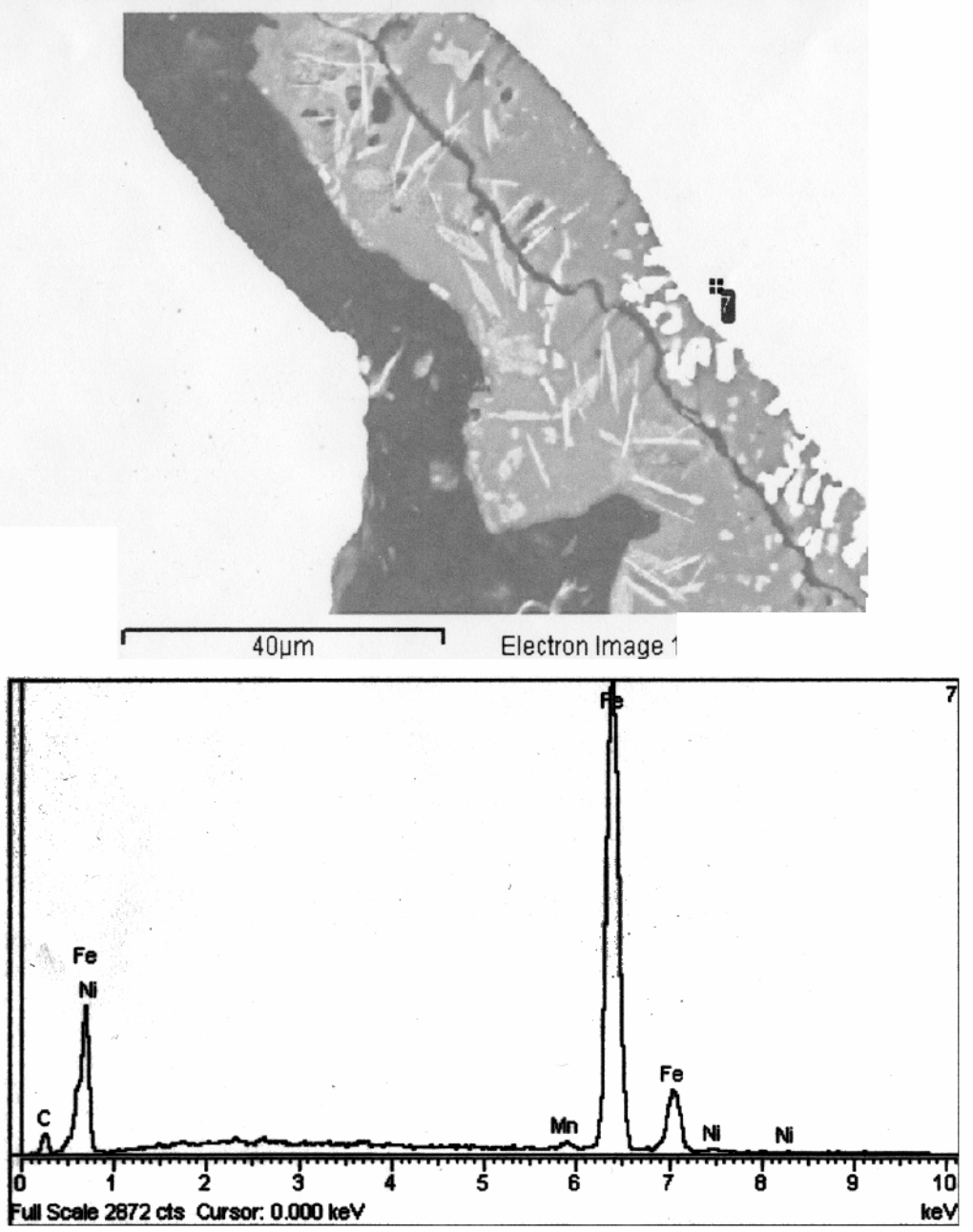

Figure B.15 Elemental Analysis of Flaw in C2CC on the End of Seam Repair C 


\section{S491(CRACKS IN METAL)}

Spectrum processing

No peaks omitted

Processing option : All elements analyzed (Normalised)

Number of iterations $=2$

Standard:

$\mathrm{Si}$ SiO2 28-Jan-2004 05:15 PM

Mn Mn 1-Jun-1999 12:00 AM

Mn Mn 1-Jun-1999 12:00 AM

Fe Fe 1-Jun-1999 12:00 AM

$\begin{array}{lll}\mathrm{Ni} & \mathrm{Ni} \text { 1-Jun-1999 12:00 AM } \\ \mathrm{T} & \text { Not defined 1-Jun-1999 12:00 AM }\end{array}$

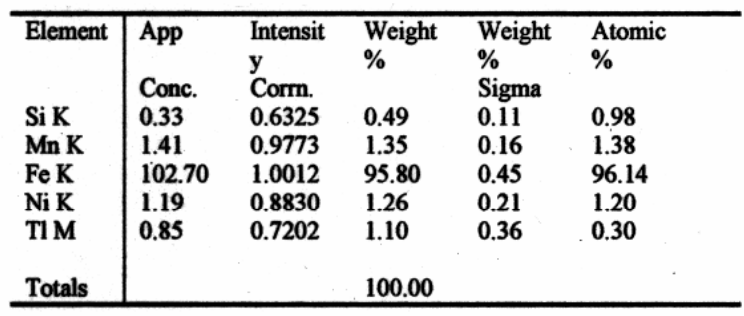

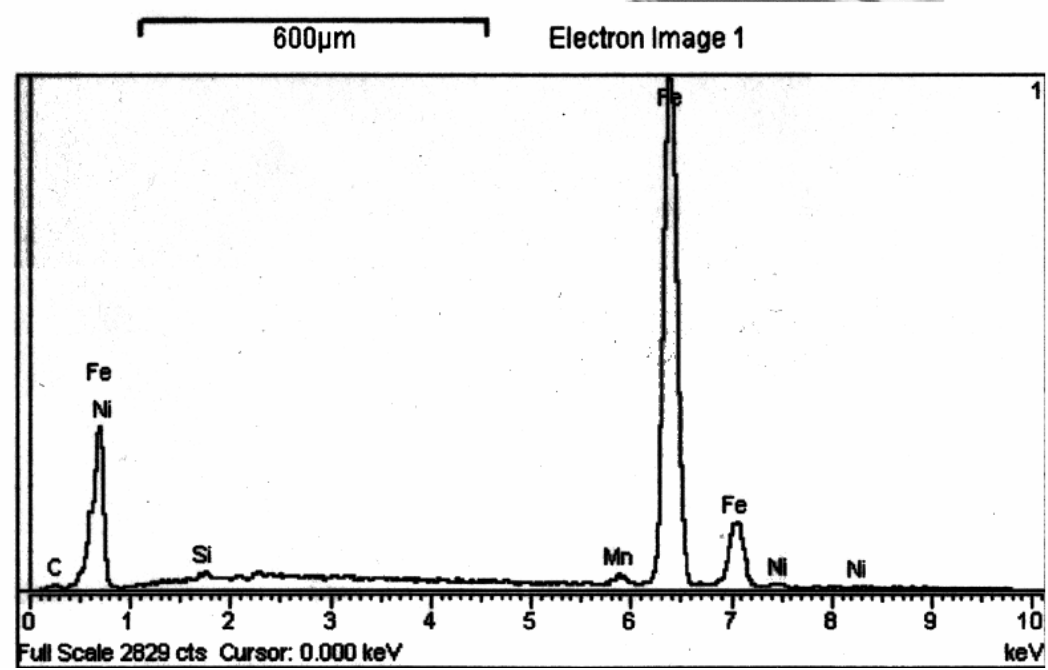

Figure B.16 Elemental Analysis of Flaw in C2CC on the End of Seam Repair C 
